Historic, Archive Document

Do not assume content reflects current scientific knowledge, policies, or practices. 



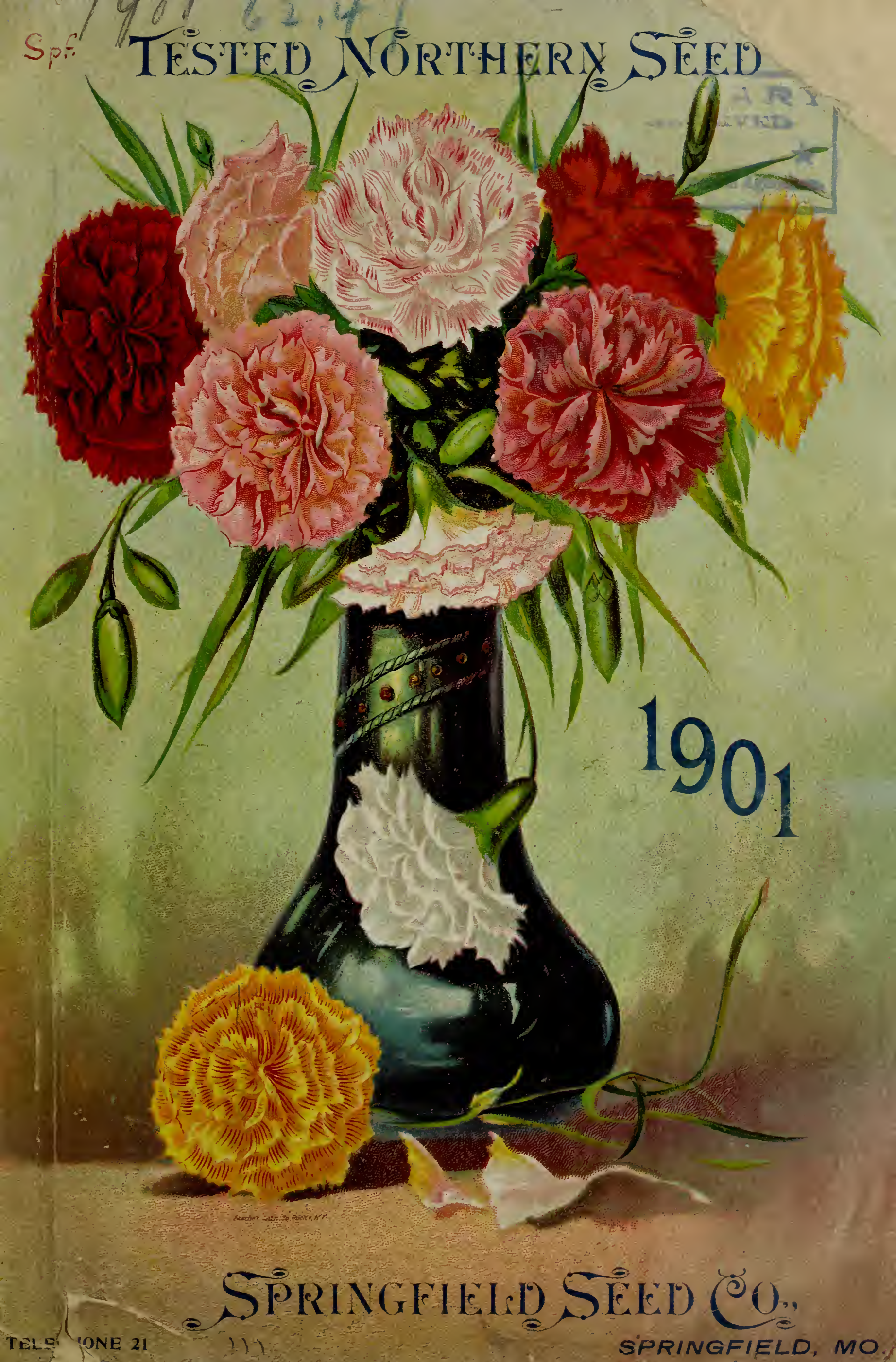




\section{THREE POTATOES.}

Introduced in 1900, and After a Thorough Test Have Proven Their Excellence.

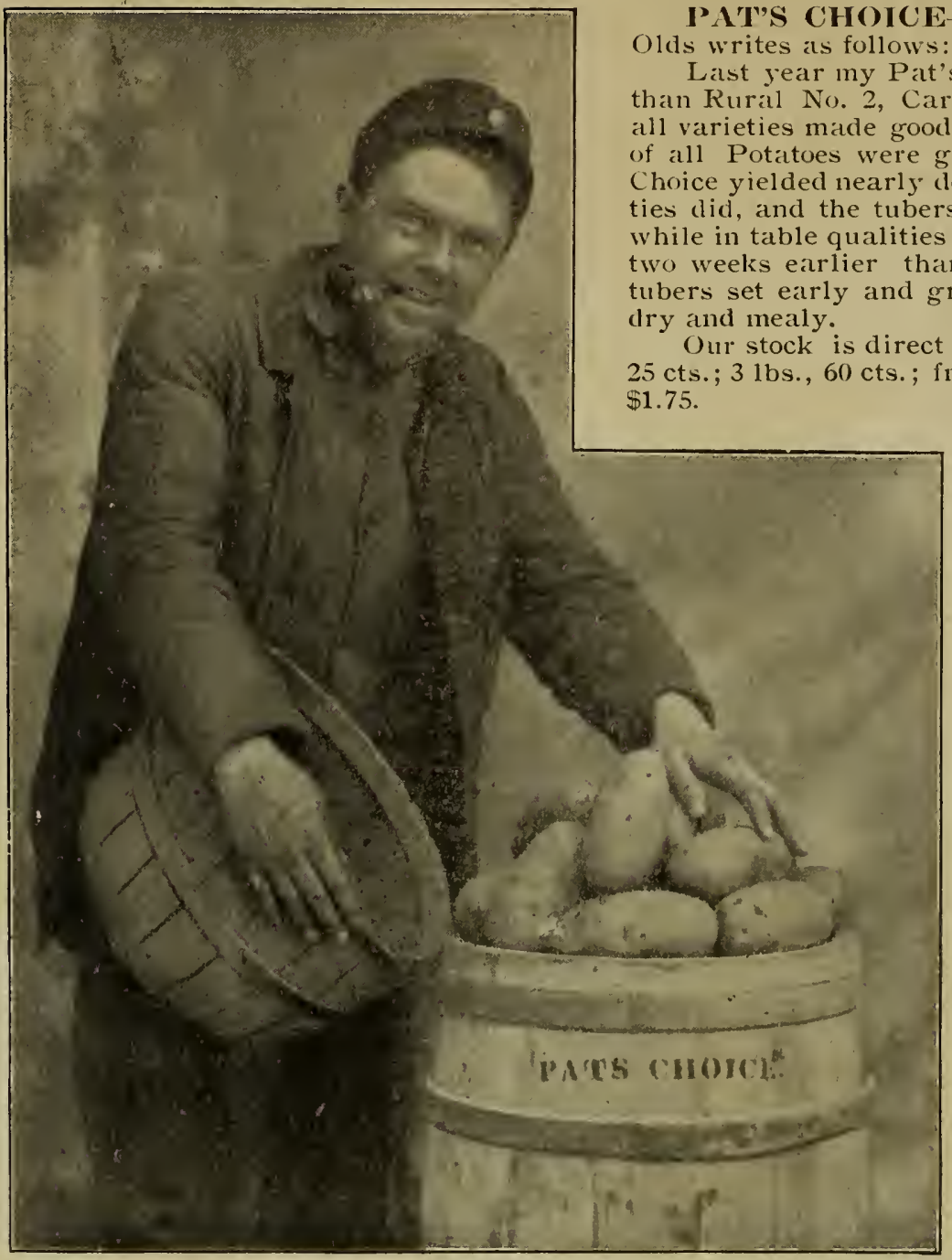

ICE-Regarding this Potato Mr. L. L. Last year my Pat's Choice yielded more in field culture than Rural No. 2, Carmen No, 1, or World's Fair, when good yields, and this year, when yields were atly reduced by drouth, Pat's Choice yielded nearly double what the above named variedid, and the tubers were handsomer and finer shape; alities it far excels any of them, maturing than Rural New Yorker No. 2. The try and mealy.

Our stock is direct from the originator. By mail, 1b, cts.; 3 lbs., 60 cts. ; freight or express, pk.. 60 cts., bu., $\$ 1.75$.

freight or express, pk. $50 \mathrm{c}$.; bu., $\$ 1.75$.

Our stock of this variety is somewhat limited.

IVHITE SICIKLE POLIS BSEAN.-It is claimed of this Bean that it is an improvement in productiveness, earliness and quality upon the Kentucky Woncler. It is especially recommended for south ern culture, possesses ir reat lengrth of nod and extreme tenderness; does not discolor in cooking. Is being offered this year as somewhat of a novelty, but we are very much inclined to state that it will be found to be all that is claimed for it. A valuable acquisition to our pole beans.

Prices, plit., 15c; pt. 25c; qt., 40c; postpilid. Freight or express, pk., $\$ 2.00$.
VIGOIROS A.-This Potato, while not as early' as 'Triumpl. is quite early. It is very handsome in appearance, beautiful flesh colored skin, is smooth and regular in form, and its quality for either baking or boiling is perfect. All facts considered, it seems to have no fault. Its vield during the past season was almost double that of any other varieties. We are especially desirous that our friends among the market garleners try a few of this remarkable variety. By mail, postpaicl: Lb., $15 \mathrm{c} ; 3$ bs., $30 \mathrm{c}$; freight or express, ple., 35c; bu, $\$ 1.10$.

FXTIRA ISAIRLY PINGREE.-Of this Potato, the originator salys it is a seedling of Marvin Bovee's of Michigan, the originator of the famnous Bovee Potato. He says of it, they are from Green Mountain, 1894, and are from three to six days earlier than the Boree, quality beingr about equal. Prices, by mail: Lb., 15c; 3 lbs., 40c, postpaid;

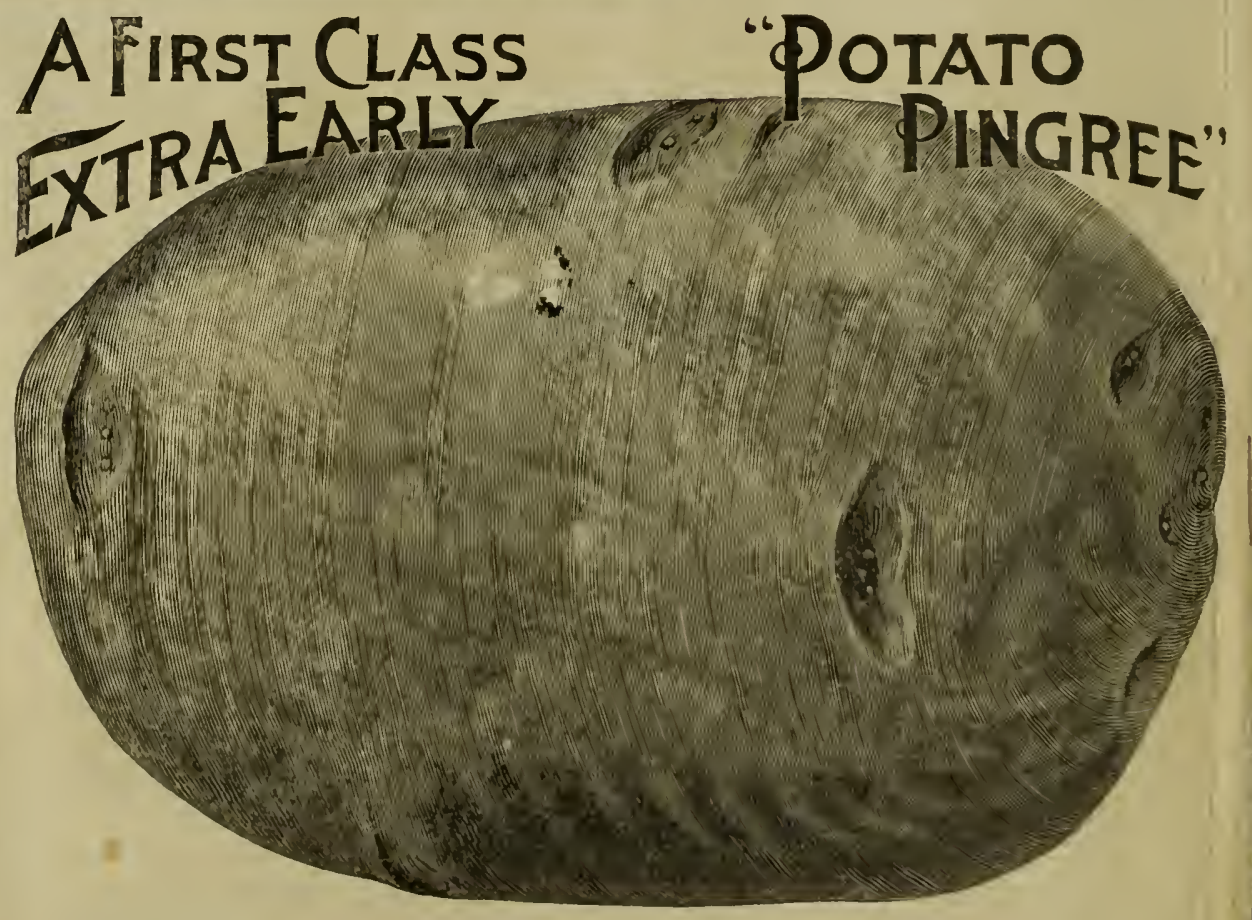
A First Class "Potato
EXTRAEARLY $2 "$ PINGREe" 
Garden, Field

and Flower Seeds FOR 1901.

WHOLESALE AND RETAIL.

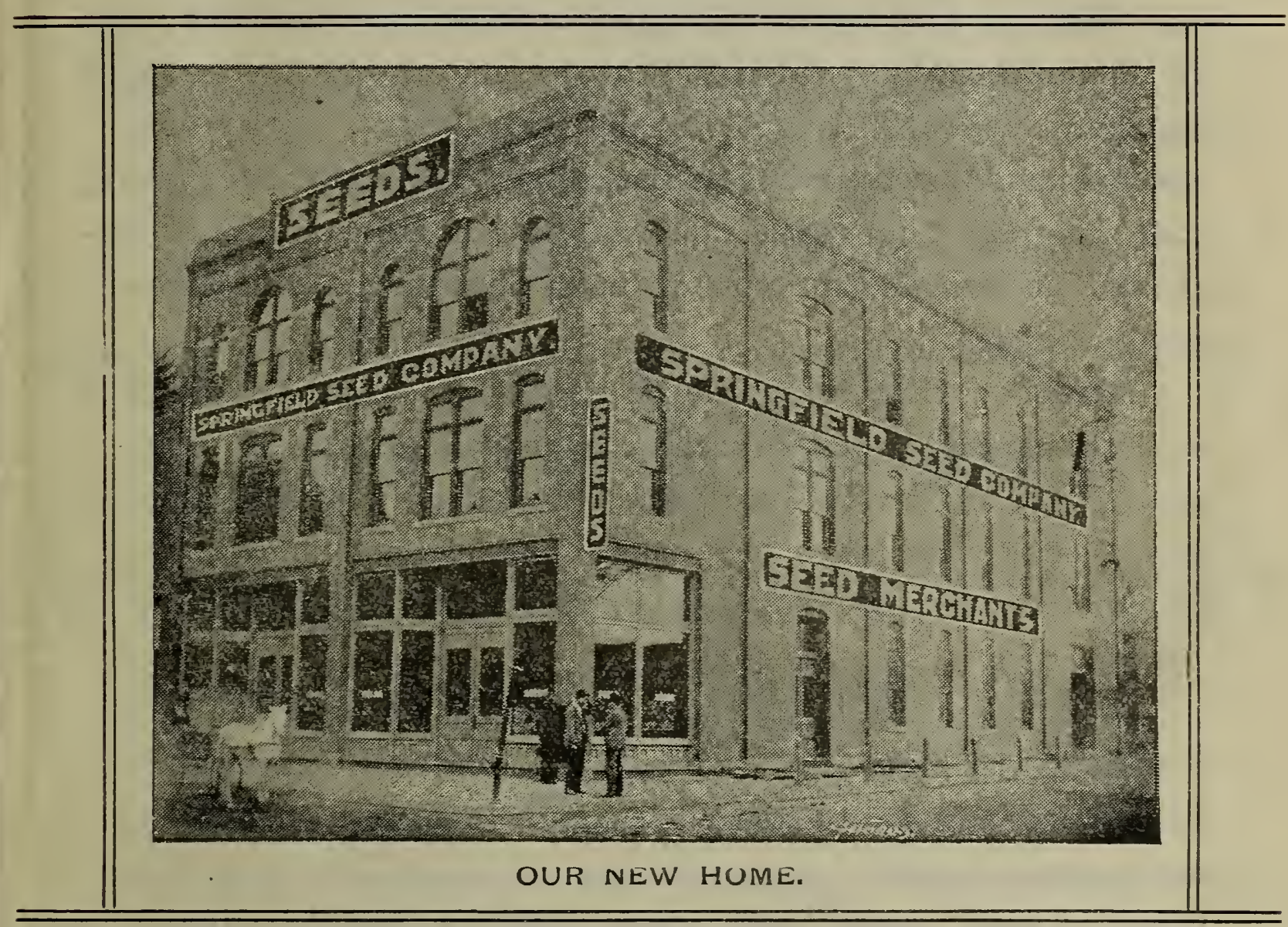

Springfield Seed Company,

320-322. West Walnut Street,

Successors to SPRINGFIELD SEED STORE.

Springfield, - - - Ritissouri. 


\section{Jo Our Patrons.}

In presenting our illustrated catalogue for the season of 1901, we desire to express our appreciation of the very liberal patronage extended us during the season just past. Our increased trade has necessitated our removal to larger and more commodious quarters, and we do not hesitate to say that we offer you the largest and best selected stock in the Southwest. As we are now situated, with modern machinery for cleaning, etc•, with greatly increased facilities for handling our business, we can assure you of much better service than heretofore

Remember that we place no seeds on commission, which always necessitates carrying over a quantity of old stocks from year to year until disposed of. Neither do we offer for sale any seeds that do not show a proper percentage of vitality after having been subjected to a thorough test.

Do not be misled by low prices, overdrawn descriptions and misrepresentations. Prices are sometimes placed so low as to make the consideration of quality an impossibility. Descriptions of so-called novelties have in some cases heretofore been so greatly overdrawn as to prove a continual source of disappointment to the grower as well as annoyance to the dealer. This idea we have tried to eliminate.

Soliciting a continuance of your favors, we remain, Respectfully,

SPRINGFIELD SEED COMPAINY• 


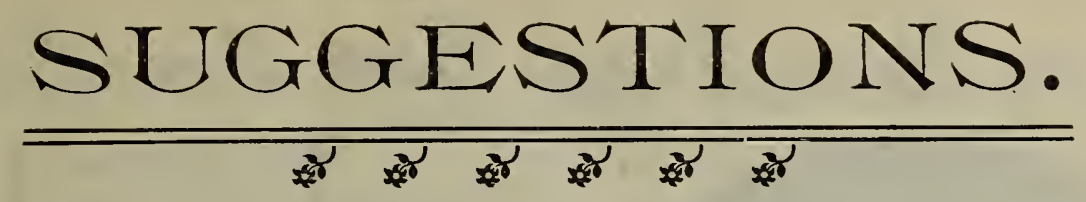

In ordering do not fail to give full shipping directions. When such are omitted, we will use our best judgment, and will forward by mail or express as may seem best.

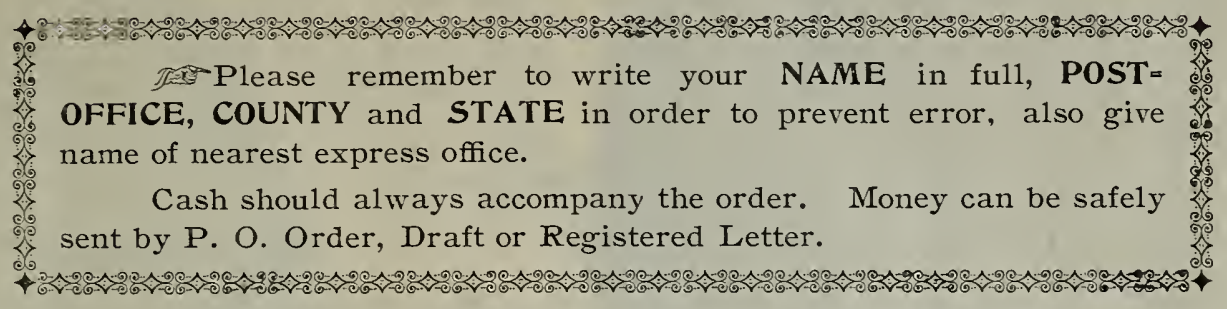

We accept Postage Stamps the same as cash not to exceed \$I.oo.

SMALL ORDERS-If you only want a single packet, do not hesitate to send for it. We take as much pains to fill small orders promptly and correctly as we do large ones.

Our aim will be to send off all orders the day received, but during the busy season it is almost impossible. Order early and avoid delays.

Market Gardners and Dealers are invited to write for our Special Price Lists.

\section{SEEDS PREPAID BY MAIL.}

The following prices include postage on packets, ounces, quarter-pounds and pounds of Vegetable and Flower Seeds, unless otherwise noted.

\section{DISCOUNTS ON VEGETABLE OR FLOWER SEEDS IN PACKETS.}

With each $\$ 0.50$ order, Select Packets amounting to $\$ 0.65$ Vegetable or Flower Seeds. With each 1.00 order, Select Packets amounting to 1.25 Vegetable or Flower Seeds. With each 2.00 order, Select Packets amounting to 2.50 Vegetable or Flower Seeds. With each 3.00 order, Select Packets amounting to 3.75 Vegetable or Flower Seeds.

This discount is only allowed for Vegetable and Flower Seeds in packets, and not for Seeds by weight or measure. Hence you send us one dollar and you will receive by mail, prepaid, $\$ 1.25$ worth of Seeds.

For club orders of $\$ 5.00$ we offer as a premium $\$ \mathbf{1 . 5 0}$ worth of Seeds in packets or ounces, either Vegetable or Flower.

We guarantee the safe arrival of all goods. Should any shipment fail to reach you in due time, please notify us at once, and we will trace, and, if lost, refill your orders free of charge.

Merchants not receiving our wholesale price card of Field Seeds, Grass Seeds, Onion Sets, Etc, are requested to write for same. These cards are issued regularly and will be mailed to merchants for the asking. Keep posted on the Field and Grass Seed market. We give you prompt service and save you freights. 


\section{Some Sood Jhings That Are Tew.}

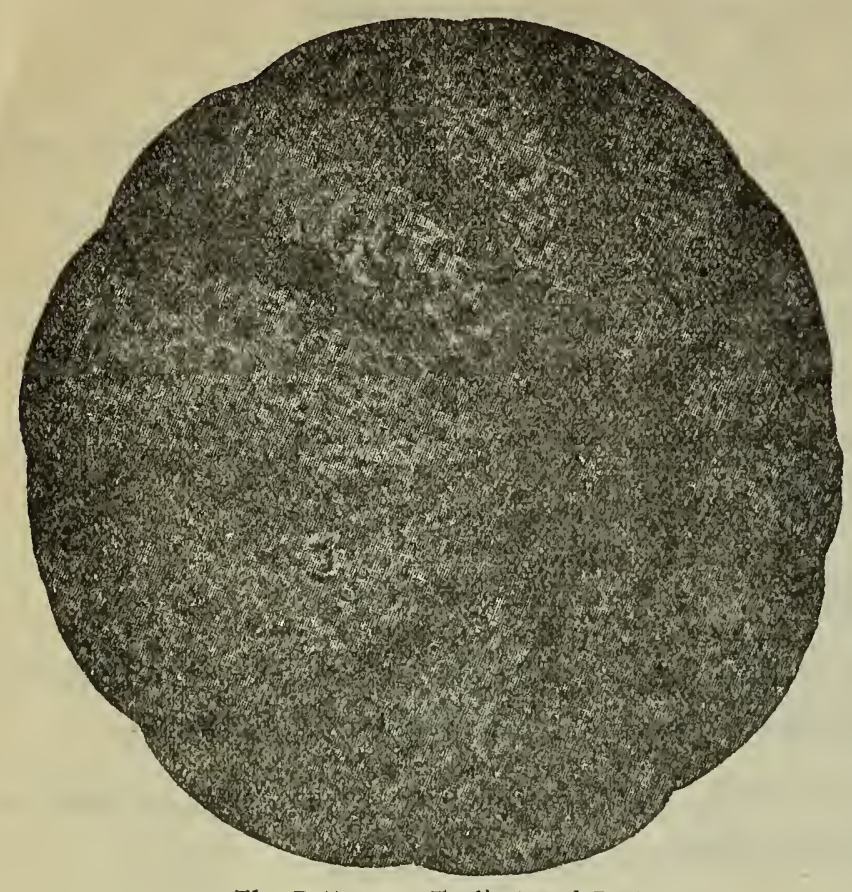

The Patterson-Earliest and Best.

\section{Jhe Patterson Relon.}

A Musk Melon of very superior qualities, originating in our immediate vicinity. Our stock (which is limited) is direct from the grower and originator of this splendid Melon. It is of the Jenny Lind type, possessing all the excellent qualities of the Jenny Lind. Earlier and of better size. We have watched the development of this melon for four seasons, and do not hesitate to recommend it to the market gardener and the shipper as being the sweetest and most productive of all extra early Melons. A sure winner and will always please the customer. Pkt, 10c; oz., 15c; 1-4 1b., 35c; 1b., $\$ 1.00$.

\section{Black Diamond,}

\section{The Best Water Relon For Market Sardeners and Shippers.}

Fruits are of mammoth size, melons weighing 75 to $90 \mathrm{lbs}$. being frequent; color is rich dark green, almost black, of uniform symmetrical shape, rounclish to bluntly oval, and this similarity of shape running through the whole field. Rind is thin but firm, flesh bright red, firm and solid, but very tender, melting and sweet. Grow strong and rapidly, ripening its fruit very early. It surpasses all other melons in productiveness and fruits remain in condition for use longer than most other

sorts. Plkt., 5c; oz., 10c; $1-41 \mathrm{~b} ., 20 \mathrm{c} ; 1 \mathrm{~b} ., 65 \mathrm{c}$, postpaid.

Free, one packet of this best of all Melons with any five packets of above varieties. Special offer to anyone buying a packet of this Melon: For the best description or testimony we will give \$5.00.

\section{Kleckly Sweet,}

\section{The Best and Sweetest Flavored Water Relon in Cultivation.}

Fruits grow uniformly to quite a large size and are oblong in form. The skin is a rich dark green, while the flesh is bright scarlet, ripening close to the rind, and is of a 1uscious sweetness, which makes this melon the finest of all Water Melons for home use. Is not a shipper, however, the fruits being too tender to stand shipment. Pkt., 5c; oz., 10c; 1-4 1b., 20c; 1b., 75c, postpaid.

\section{Solden Hubbard, \\ The Best Fall and Winter Squash.}

This is a perfect type of the green Hubbard, except in color, which is bright orange red, very showy and attractive. The fruits are very uniform in size, weighing from 6 to 8 pounds, and in shape arellike the green Hubbard. The flesh is deep) orange, much richer in color than the Hubbard, cooks very dry, fine grained and of excellent flavor. Fruit matures very early. Their kceping qualities are fully equal to the green variety and they can be held over in good condition for spring use. It is a vigorous grower and in productiveness far excels the old variety. Owing to its handsome appearancel and its excellent qualities the Golden Hubbard is bound and cleserves to become a most popular variety. Plit., 10c; oz., 20c; 1-4 1b., 60c, postpaid.

\section{Rustralian Brown,}

\section{An Extra Early, Long-Feeping Onion.}

This new Onion was recently introduced into the United States from Australia, where it is the only variety plinted. It has succeeded admirably in this country and is without doubt the most valuable yariety introduced for a generation.

It is of medium size, of an almost grlobular form, and the color of the skin is a (leep) amber brown, distinct from all other Onions. It is extremely carly, and planted with Wethersfield it proved to be nearly four weeks earlier. This Onion is extremely hard and firm and of tine flator, and will keep almost indefinitely. The renatrable character of long-keeping, and its early ripening, makes Australian Brown the best Onion to grow for profit for the masket gardener, and it is equally valuable for the private planter. Plit., 10c; oz., 25c; 1-4 1b., 70c; 1b., \$2.25, postpaid.

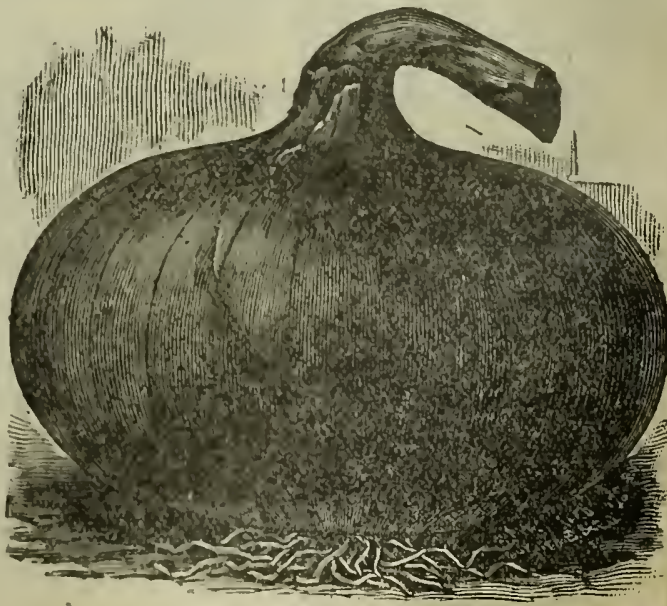

Onion-Australian Brown. 


\section{Kendel's Early Siant Sweet Corn.}

After having been thoroughly tried for the past three seasons, Kendel's Giant has proven itself to be beyond question the best of all varieties of Sweet Corn now in cultivation, combining those qualities that have been so long sought for, namely: size, quality and earliness, it being ready for market almost as early as Crosby's Early, attaining twice the size, ears being eight to ten inches in length. We feel justified in

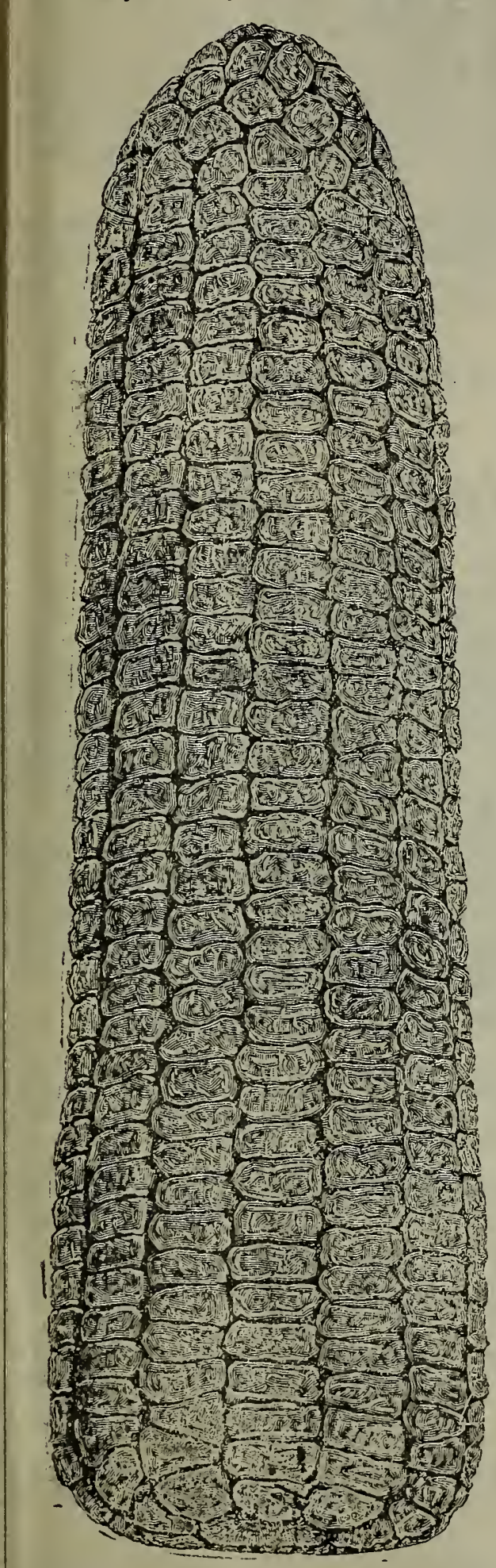
saying that all who try Kendel's Early Giant, for both the home and market garden, will find it far superior to any variety now in cultivation. We shall during the season enclose free samples with every mail order amounting to twenty-five cents or more. Price, postpaid, pint, 15c; quart, 30c. Freight or express, peck, $80 \mathrm{c}$; per bushel, $\$ 2.00$.

\section{Siant Sreen Pod Stringless Valentine.}

A decided improvement over the Stringless Green Pod recently introduced by Mr. Burpee, which for the past two or three seasons has been conceded to be the best green pod Bean on the market, having almost taken the place of our old favorite, Ex. Early Red Valentine. Giant Green-Pod Stringless Valentine is certainly the only thing that will be offered this season which will prove superior to Burpee's Stringless. In earliness and productiveness far superior to the old Valentine, in size and quantity, superior to all. Pkt., 10c; pint, 20c; quart, 40c, postpaid.

\section{American \\ Sinseng.}

The cultivation of American Ginseng is at present receiving much attention. That Ginseng can be grown successfully, and with great profit, has been demonstrated beyond question, the supply of wild roots being greatly inadequate to the demand. The cultivated root being a better quality and size also commands a much better !price.

Ginseng requires a rich, loose loam, partial shade and a heavy mulching of leaves or similar covering during the dry season and autumn, which should be left on to act as a: fertilizer and. for protection during the winter, also to preserve moisture.

Plant seed seed six inches each way in beds, covering to a depth of two inches.

We offer seeds by mail at 5 cents each, $\$ 4.50$ per hundred.

Roots, first size, three years old, $\$ 18$ per hundred.

Second size, two years old, $\$ 12$ per hundred.

One year old roots, \$8 per hundred.

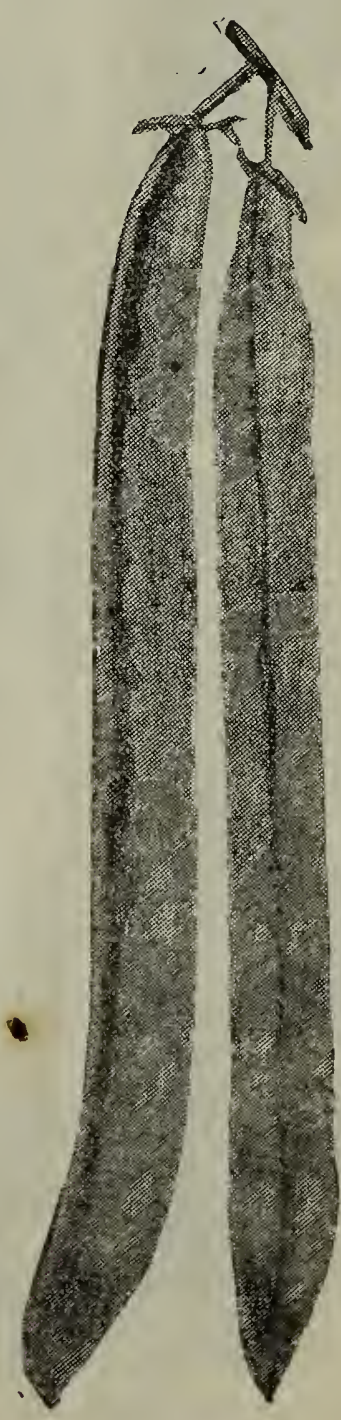




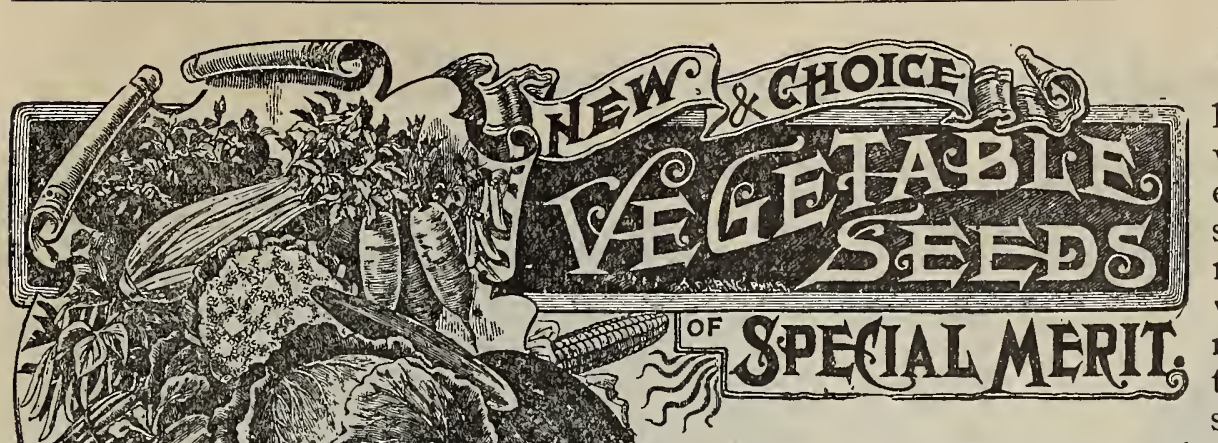

$\mathrm{N}$ this department we offer a list of all known varieties of real value and exclude everything worthless; also leave out an endless number of kinds for which there is no demand. We are careful to avoid offering the same variety of seeds under different names; also to avoid using misleading descriptions.

By adhering strictly to this idea we have made friends of many who have been misled from year to year by overdrawn descriptions of worthless novelties, and by Seedsmen who desire by substitution to make many varieties out of one.

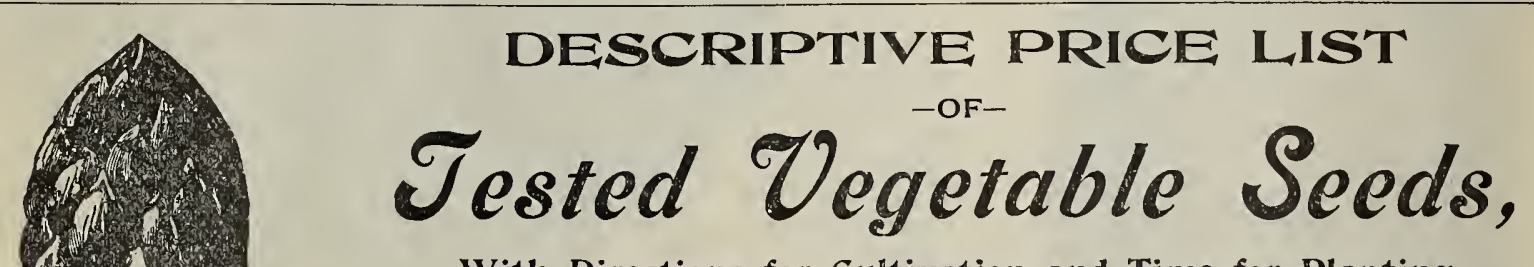

With Directions for Cultivation and Time for Planting.

JERUSALEM ARTICHOKE.

A well-known vegetable produced from tubers, somewhat resembling potatoes. It makes an excellent food for stock, and is especially fine forage for hogs. Planted similar to potatoes, and as early as the season will permit. Pk., 30c; bu., $\$ 1.00$.

\section{ASPARAGUS.}

Soak the seed 24 hours in warm water, and sow very early in the spring, thinly, in rows one foot apart; keep clean by frequent weeding and hoeing. At one or two years old, transplant to permanent beds.

Conover's Colossal.-A remarkably vigorous grower, producing a good crop at two years from seed, and we do not hesitate to recommend it as the best variety grown in this section. Pkt., 5c; oz., 10c; 1/4 1b., 20c; 1 1b., 50c.

Palímetto.-Earlier than Colossal. Pkt., 5c; oz., 10c; 1/4 1b., 25c; 1 1b., 65c.

Columbian White Mammoth.-A variety distinct from all others. Producing pure white shoots which retain their color as long as it is fit for use. Shoots thick and stocky. This variety is growing in favor from year to year. Pk., 5c; oz., 10c; 1/4 1b., 25c; 1 1b., 90c.

Asparagus Roots.-Strong, two-year-old Roots, 75c per 100; $\$ 6.00$ per 1000 .

\section{Dwarf Bush, or Snap Beans. GREEN PODDED VARIETIES.}

Extra Early Refugee, or Thousand to One.-This variety combines the two qualities of being extra early and very productive. Used largely for pickling. Marly Mohawk.-A standard early variety. A hardy vigorous grower; yields heavy, and especially adapted for poor land. For prices see foot-line.

Round Podded Red Valentine.--This variety, so long the favorite of the market gardener and the trucker, still retains its well-deserved reputation as one of the finest snap varieties. Pk., $\$ 2.00$.

Early Long Yellow Six Weeks.-Pods when young are long and of excellent quality. A standard early sort for general crop.

Best of All.-An excellent green pod variety, especially adapted for home gardeńn. Pods very brittle and retain this quality well.

Dwarf Horticultural.-Sometimes called the Boston Favorite-especially prized as a shell bean, also an excellent variety as a snap bean or for baking.

On above varieties not otherwise noted, prices: Pkt., 10c; pt., 25c; qt., 40c: all postpaid. Peck $\$ 1.50$, not prepaid. 


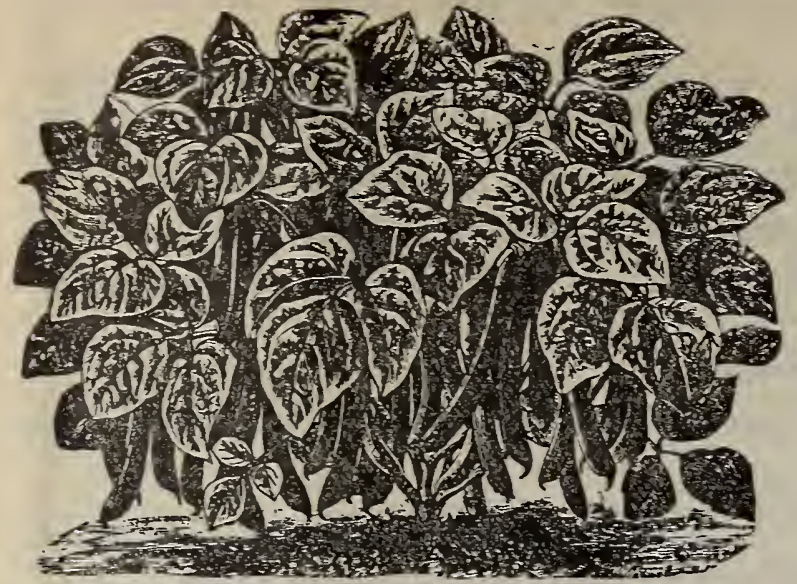

Improved Tree Bean.-Resembling the small old-fashioned Navy. Adapted especially for field culture. Pkt., 10c; pt., 20c; qt., 35c.

White Marrow.-Similar to the White Navy, but 1arger. Pkt., 10c; pt., 20c; qt., 35c.

Koyal Dwarf White Kidney.-A late variety, kidney-shaped, extra large seeded-can be used as a greenor dry bean. Pkt., 10c; pt., 20c; qt., 35c.

Burpee's Stringless Green Pod.-Absolutely the best green pod bean in cultiration. Positirely stringless, remains tender and crisp longer than any other variety, succulent and rich of flaror, hardy and prolific, earlier than Yellow Six Weeks, pods full and round, longer and straighter than Valentine, a grand, good sort and especially raluable for the home table. Pkt., 10c; pt., 25c; qt., 40c; postpaid, pk., $\$ 1.75$.

Burpee's Stringless Green Pod.

\section{BUSH LDLA BEANS.}

Henderson's Bush Lima.-The first Bush Lima Bean erer introduced. Very productive, and of an excellent quality, is at least two to three weeks earlier than any of the pole varieties, and a very prolific bearer until frost. Pkt., 10c; pt., 25c; qt., 40c, postpaid; pk., \$1.60, by freight or express.

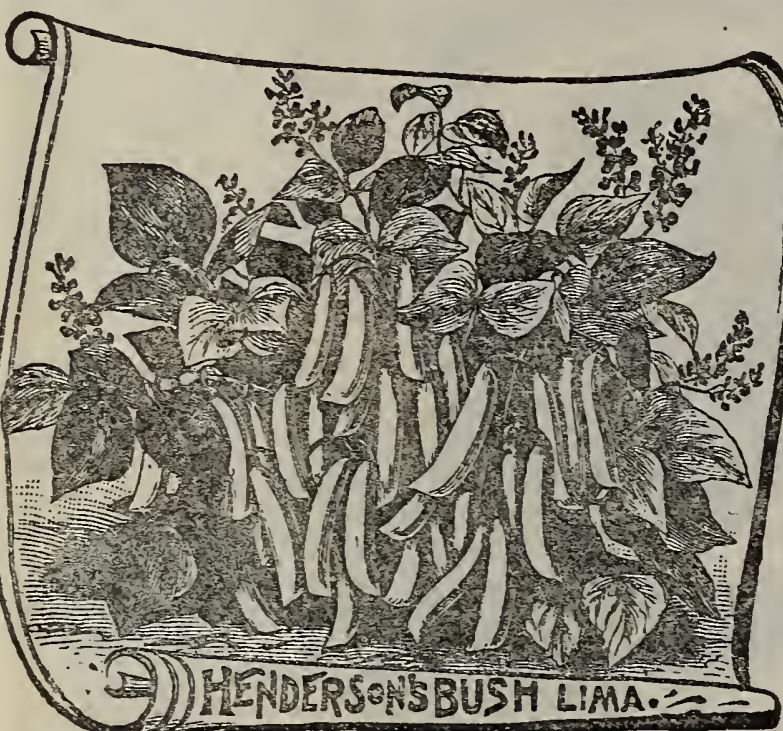

\section{DIVARF WAX PODDED VARIETIES.}

Improved Golden Wax.-An old standard rariety, well nown as the earliest and best of Wax Podded Beans.

Prolific German Black Wax.-An excellent round pod variety, very early, and ready for the table in 35 to 40 days from germination.

Wardwell's Kidney Wax.-Remarkably rigorous, hardy and productive; the pods rery large, smooth, tender and perfectly stringless. Used largely by market gardeners as a shipping variety.

Davis Kidney Wax.-A new variety, beans white, large and plump, excellent for canning and a specially good shipper, pods very long and uniform size and shape.

Scarlet Flageolet Wax.-Very large, long and tender, excellent for midsummer planting.

Prices when not otherwise noted, postpaid: Pkt., 10c; pt., 25c: qt., 45c; pk., \$1.50, not prepaid.

\section{WELL-KNOWN POLE BEANS.}

Wutch Caseknife.-Very early, pods long and flat, beans pure white and of excellent quality, used either green or dry.

Sonthern Prolific.-Used as either a Pole or Cornfield Bean. Will bear till frost.

speckled Cut-Short, or Cornhill.-Very profitable and popular for planting among corn.

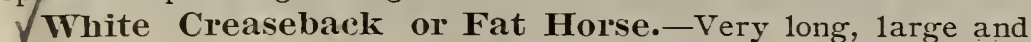
pecabsolutely stringless, beans growing in clusters.

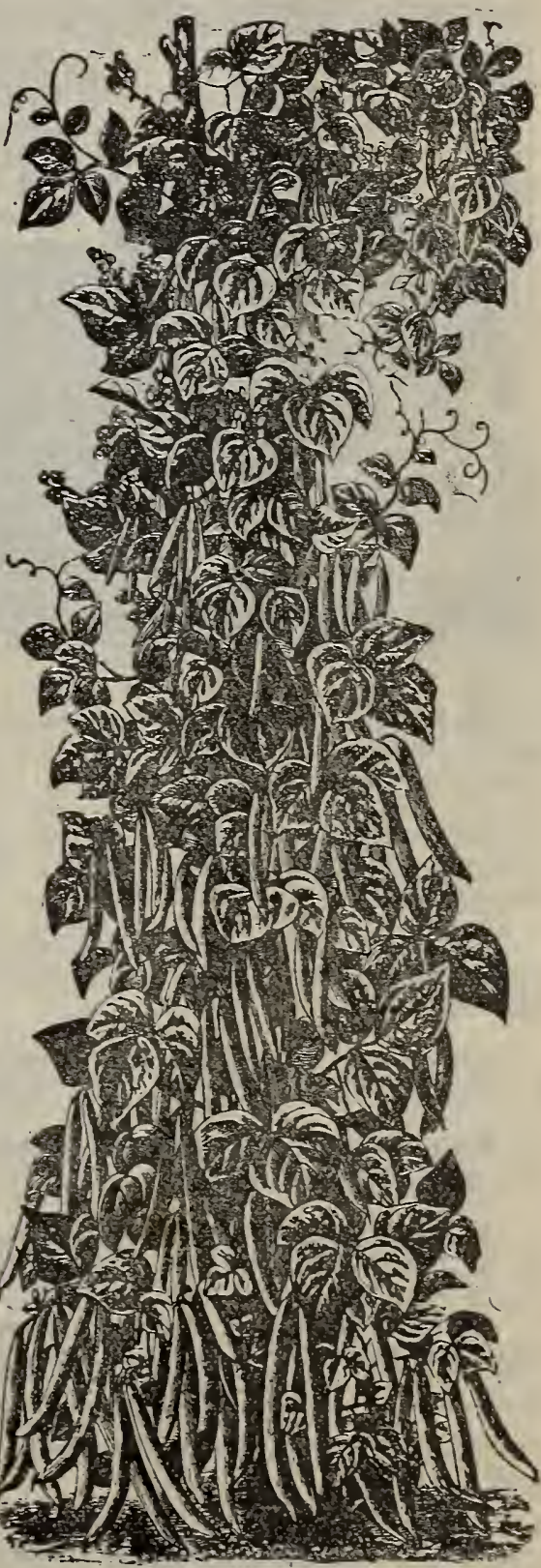

Kentucky Wonder 
Lazy Wife.-Pods of immense size, unexcelled for tenderness and flavor, 1argely used as a winter Bean,

Kentucky Wonder, or Old Homestead.-Regarded as the Best Green Podded Pole Bean grown. Enormously productive. Pods hanging in great clusters and of a beautiful silvery green color. An ideal Bean. Its flavor is most delicious. Rapidly growing into favor and the coming season will be more extensively grown than any other pole variety. Pkt., 10c; pt., 25c; qt., 45c; pk., $\$ 2.00$, not prepaid.

Horticultural.-Immensely productive and very large, used for Shelling or String Beans.

King of the Garden Lima.-A splendid Lima. Grows very rapidly and attains immense size. Matures early. Pkt., 10c; pt., 25c; qt., 45c; pk., \$1.75.

Large Lima.-Late standard variety and well known.

Hemisphere or Big Sioux.-In some localities known as the October Bean. A pole variety of rare excellence, used largely for late planting.

Prices, postpaid: Pkt.. 10c; pt., 30c; qt., 45c; pk., \$1.75, not prepaid.

\section{MARKET GARDENERS WILL PLEASE WRITE FOR OUR SPECIAL LIST.}

NOTE-Peas, Beans and Corn in large quantities, sent by freight or express, at purchaser's expense in all cases.

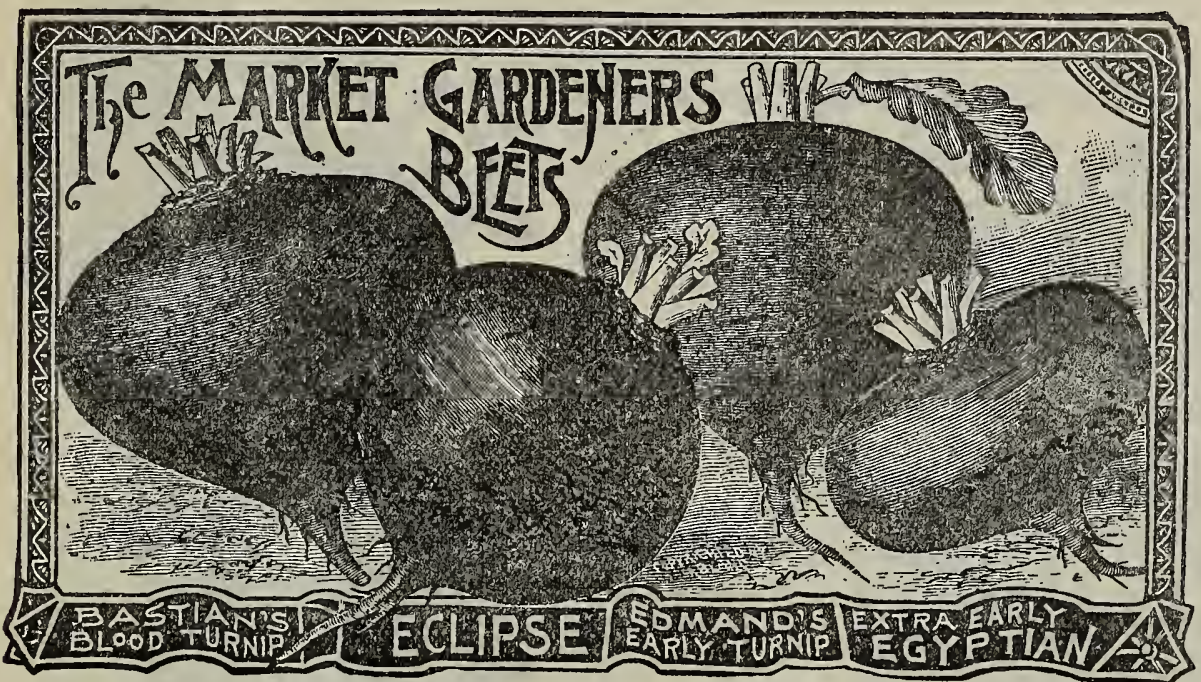

Crosby Egyptian-Unsurpassed for earliness. Originated from the old flat Egyptian. Handsome in form. Deep rich red in color. Splendid quality, rapid grower and free from cracking. Very much in demand by market gardeners for forcing. Pkt., $5 \mathrm{c}$; oz., 10c; $1 / 4$ 1b., 25c; 1 lb., $50 \mathrm{c}$.

Ermand's Warly Bloon Turoin. -This variety is greatly esteemed by truckers and gardeners for a general crop and is never coarse, tough or stringy. Our stock has been selected from the best French grown stock. Pkt., $5 \mathrm{c} ; \quad \mathrm{Oz} ., 10 \mathrm{c} ; 1 / 4$ 1b., $15 \mathrm{c}$ $1 \mathrm{~b} ., 50 \mathrm{c}$.

Eclipse.-In this we offer the most popular and best beet we can possibly recommend. Beautiful rich color. Smooth, round in shape. It has many important qualities not possessed by other sorts. Our strain is pure. Pkt., 5c; oz., 10c; 1/4 1b., 15c; 1b., 50c.

Lentz Extra Early.-Round, smooth, dark red. Very tender. Somewhat larger than the Egyptian. Fully as early and a good cropper. Ready for bunching in six weeks. Pkt., 5c; oz., 10c; 1/4 1b., 15c;1b., 50 c; postpaid, 5-1b lots, $\$ 2.40$.

Egyptian Blood Turnip.-The standard. Deep red in color. Tender, finely grained, highly flavored and sugary. It is a deservedly popular favorite. Pkt., 5c; oz., 10c; 1/4 1b., 15c; 1b.. 50c; postpaid, 5-1b. lots, $\$ 2.40$.

Dewing's Early Blood Turnip.-Superior table beet. A good keeper, early, skin smooth. Pkt., $5 \mathrm{c}$; oz., 10c; $1 / 4$ 1b., 15c; 1b., 50c; postpaid, 5-1b. 1ots, $\$ 2.40$.

Improved Early Blood Turnip.-A standard variety. Pkt., 5c; oz., 10c; 1/4 1b., 15c; 1b., 50c; post-paid, 5-1b. lots, $\$ 2.40$.

Long Smooth Dark Blood.-Unsurpassed for winter use. A fine keeper and good for stock. Pkt., $5 \mathrm{c} ;$ oz., $10 \mathrm{c} ; \mathrm{r} / 41 \mathrm{~b} ., 15 \mathrm{c} ; 1 \mathrm{~b}$., 50c; $51 \mathrm{bs}$., $\$ 2.25$, postpaid,

Swiss Chard.-Cultivated for its leaves only, used as greens. Stems being cooked like asparagus, while the leaves are served as spinach. Pkt., 5c; oz., 10c; 1-4 1b., 15; 1b., 50c; postpaid, 5-1b. 1ots, $\$ 2.40$.

Dealers will please write for special prices on bulk garden seed, field seeds, onion sets, potatoes, etc.

Do not forget that we offer a liberal discount on Seeds in packets. See page three and order șheets, 


\section{BEET--MANGEL WURZEL.}

THESE GIANT BEETS are grown extensively in all parts of the country for feeding stock. Sow in April or May in drills three feet apart, and thin or transplant to ten inches in the row.

If your soil is deep and mellow, try the long varieties; if shallow, the round kinds. They produce enormous crops and nothing pays the farmer or stock-raiser better than Mangels. Their value cannot be over-estimated, analysis having demonstrated the fact that 400 pounds of Mangels are equivalent to roo pounds of the best hay. Crops of $\mathrm{x}, 000$ bushels to the acre is an ordinary yield, while with good culture 2,000 bushels have been grown on this amount of ground. Everyone who keeps even a single cow should grow some of these for winter use. While they are not only the cheapest of foods for all kinds of live stock-horses, cattle, sheep, hogs and chickens - they are easily grown, yield enormously, and greatly increase the yield of milk, but add largely to the health and general condition of all kinds of stock. As soon as frost occurs, dig the crop. Store in cellar or bury in the field. We would
especially recommend this crop to the farmers of Southern Missouri. Sow 6 pounds of seed to the acre.

When ordered by express or freight deduct $5 \mathrm{c}$ per pound. Special prices on large quantities.

Improved Manmoth Long Red.-A justly celebrated variety. Sometimes attaining a weight of 17 pounds, making it a remarkable cropper. Frequently producing 35 to 40 tons per acre. Should be grown on deep, rich soil.

Golden Tankard.-One of the most valuable of all the yellow varieties, containing a large percentage of sugar. Special features are its nutritious and milk-producing qualities. A good keeper. Suitable for a lighter soil than the Mammoth.

Red Globe.-A large globular red sort, even a better keeper than the Long Red. It produces fine crops upon shallow soil, which, added to its fine grain and excellent keeping qualities, renders it the most desirable.

Yellow or Orange Globe.--Remarkably smooth in shape, considering the large size attained. Flesh white and a great keeper. Will stand a dry season exceedingly well, hence good for late planting.

Vilmorin's Improved Sugar.-A variety originating in France. It differs from the Mangel Wurzel in containing the largest percentage of sugar of any known variety. In size it is medium, yielding in this section from 10 to 20 tons per acre. Containing about 18 per cent sugar. Cannot be over-estimated for any purpose. Should be grown on deep soil.

Any of the above varieties, large pkt., 5c; 1-4 lb., 10c; lb., 30c: 5 Ibs., \$1.25, prepaid.

\section{BRUSSELS SPROUTS.}

Plants very hardy, grow two to three feet high and produce from the sides of stalk sprouts resembling cabbage heads about 2 inches in diameter. Quality fine when cooked and served like Cabbage. A splendid vegetable. All who have tried it prefer it to Cabbage. Easily grown, sown in May same as Cauliflower and transplant to rows 3 feet apart, 1 foot in rows. Pkt., 5c; oz., 15c; 1-4 1b., 40c; 1 b., $\$ 1.40$.

\section{CABBAGE.}

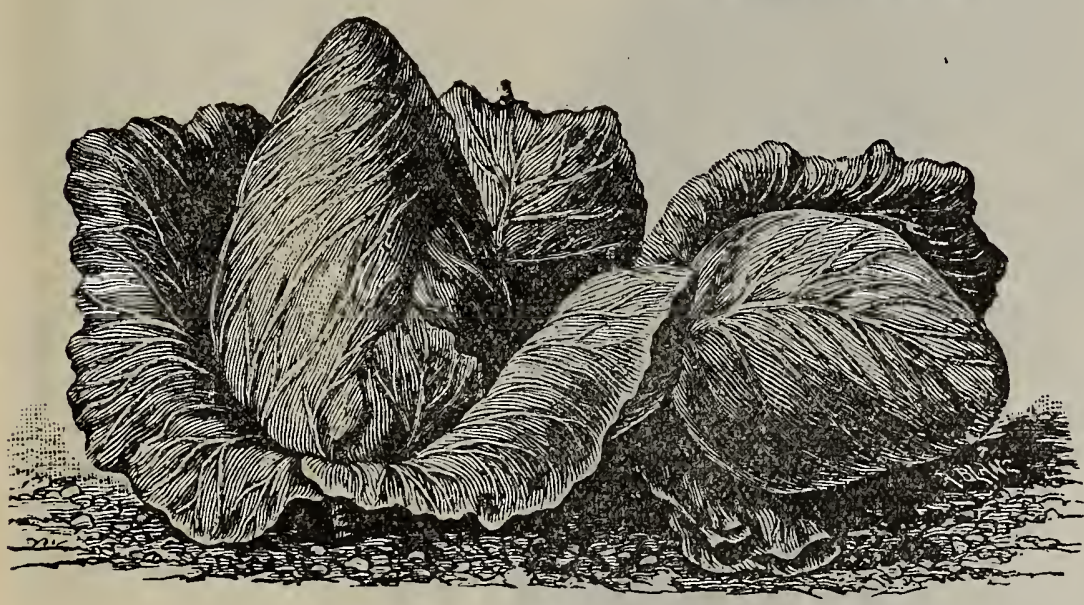

Extra Early Jersey Wakefield.

Extra Early Jersey Wakefield.-This old variety needs no description. Has stood for twentyfive years without an equal for the home or market garden. The best of all early Cabbage. Pkt, 5c; oz., 20c; 1-4 1b., 60c; 1b., \$2.25.

Cliarleston or Large-Headed Wakefield-A prize-winner among early Cabbage. Coming directly in succession to Jersey Wakefield, having the characteristics of this variety, but almost twice the size, we do not hesitate to recommend the Charleston to any customer growing early Cabbage, for whatever purpose. It fills a long-felt want for an early Cabbage. Larger than the Jersey Wakefield. Pkt, 10c; oz., 30c; 1-4 1b., 75c; 1b., \$2.25.

Henderson's Early Summer.--A flat-heading variety about ten days later than Jersey Wakefield, and for years has headed the list of second early Cabbage. Pkt, 5c; oz., 15c; 1-4 1b., 60c; 1 b., $\$ 2.00$.

Early Winningstadt.-A very old and standard variety, without doubt the hardiest of all sorts. Vigorous in habit. A second early pointed variety that is certain to head in almost any kind of a season. Heads are regular, conical and a good keeper. Pkt, 5c; oz., 15c; 1-4 1b., 40c; 1b., \$1.25.

Early Flat Dutch-A fine second early variety. Pkt, 5c; oz., 20c; 1-4 1b., 50c; 1b., \$1.50.

Early Drumhead-Medium early and a sure header, round and solid. Pkt, 5c; oz, 20c; 1-4 1b., 60c; $1 \mathrm{~b}, \$ 2.00$.

Sure Head-A mid-summer variety. Very appropriately named from its certainty to head. Large, round and flat. Very firm and a good keeper. Fine for shipping. Pkt, 5c; oz., 20c; 1-4 1b., 50c; 1b., \$1.90.

All Seasons--Similar to Sure Head, but somewhat earlier and always brings excellent results. Pkt, 5c; oz., 20c; 1-4 1b., 60c; 1b., \$2.00.

Vandergaw-This variety was originated several years ago by a Long Island grower, and has gained great favor as a general crop Cabbage. If planted early is ready for use eight to ten days after Henderson's Early summer, and has the advantage of being much larger. Grown in every section this season. Several crops have averaged 125 to 140 pounds to the dozen. Pkt, $5 \mathrm{c} ; \mathrm{oz} ., 20 \mathrm{c} ; 1=41 \mathrm{~b} ., 60 \mathrm{c} ; 1 \mathrm{~b}$., $\$ 2.00$, 
Henderson's Succes sion.-A second early, (2) Uniformly large, full and handsome. Has had a very extensive sale. A general favorite everywhere and one we can safely recommend for all purposes. Pkt, 5c; 0.z, 20c; $1-4$ 1b., 60c; 1b., \$2.00.

Premium Large Late Flat Dutch-This is perhaps the most universally known of all the late varieties. It is used both for early fall and winter keeping. Besides being of re-

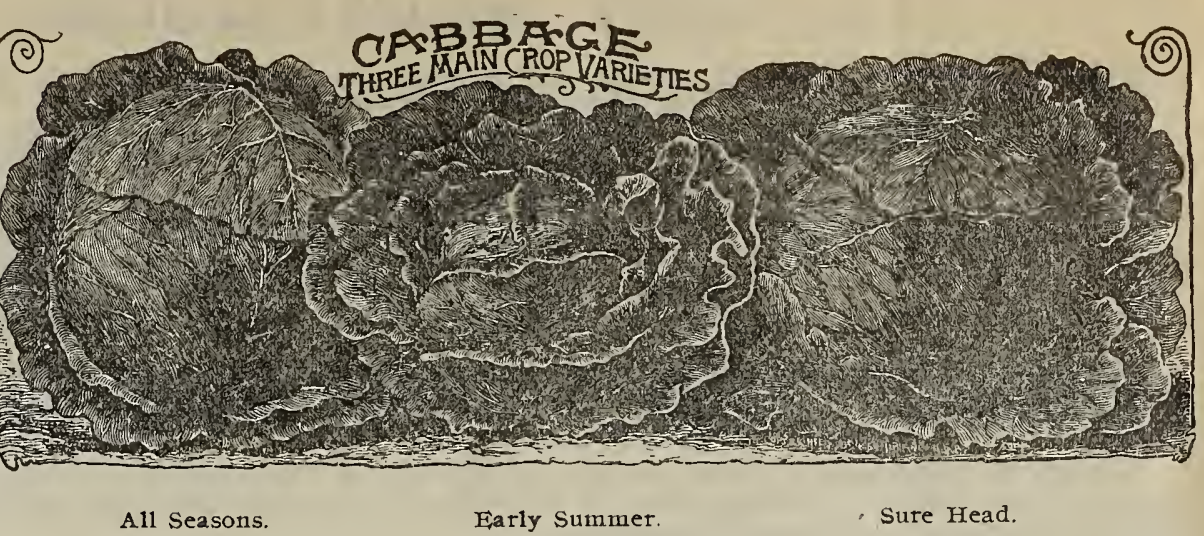
markable size, it seldom fails to head under any circumstances. Our seed of this variety is of a highly superior quality and has never failed to give full satisfaction to our trade. Pkt, 5c, oz., 15c, 1-4 1b., 50c, $1 \mathrm{~b}$., $\$ 2.00$.

Large Late Drumhead-Heads enormous. A very hardy and especially desirable winter sort. A fine shipper. Pkt., 5c; oz., 15c; 1/4 1b., 50c; 1b., $\$ 1.75$.

Autumn King-This variety is of late introduction, having been on the market but a few seasons. A11 growers who have thus far tested it have been very successful. It seems to give universal satisfaction and we predict that it will prove a valuable acquisition to our list of late varieties. Pkt., 5c; oz., 20c; $1 / 41 \mathrm{~b} ., 50 \mathrm{c} ; 1 \mathrm{~b} ., \$ 1.75$.

American Drumhead Savoy-The leading variety of all the Saroys. Special attention should be given to this class, particularly where quality rather than quantity is desired. Valuable for the private garden. Of sweeter flavor than other Cabbages, especially when touched slightly by frost. Rapidly gaining favor as the most delicious of all regetables. Pkt., 10c; oz., 25c; 1/4 1b., 75c; 1b., \$2.25.

We are Springfield Agents for Planet Jr. Garden Tools. Write for Catalogue.

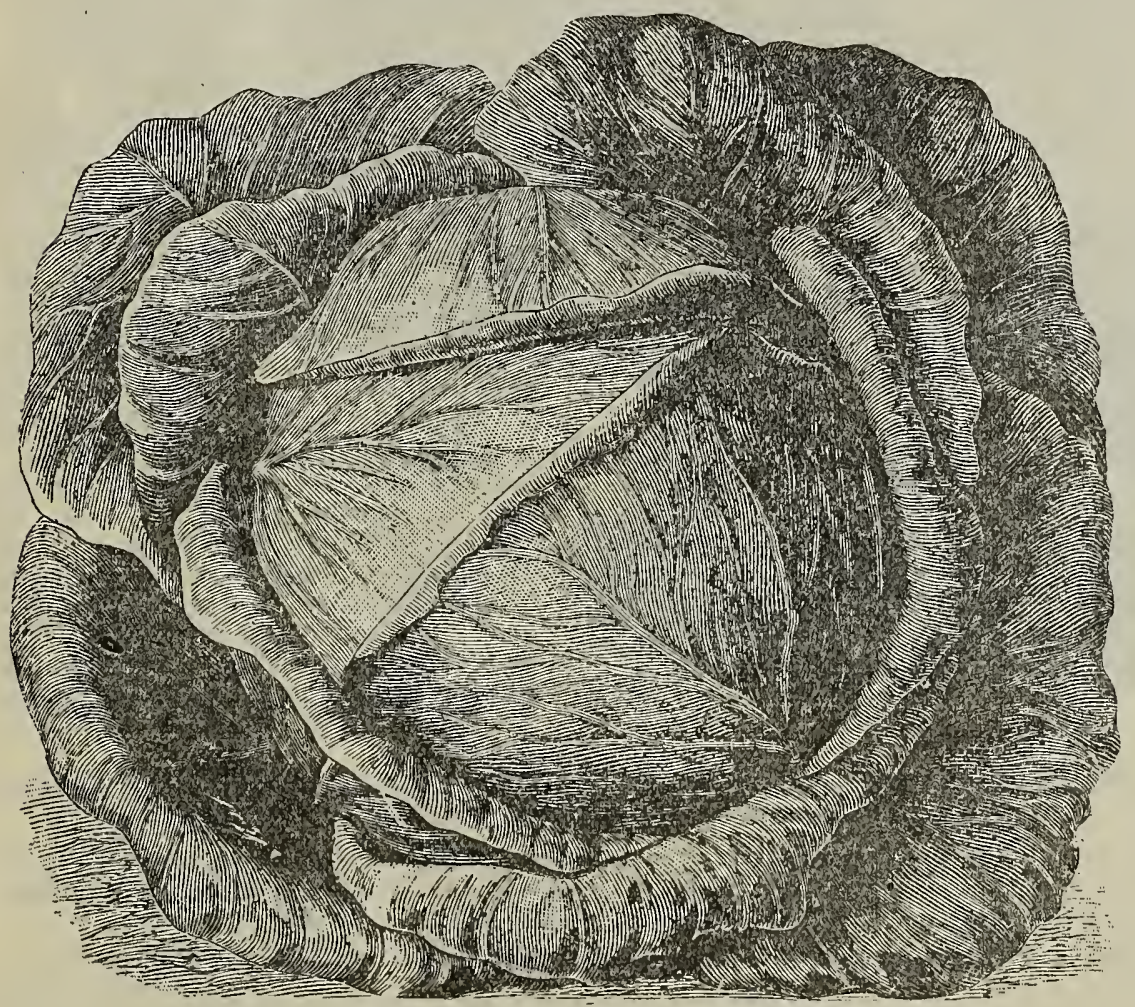

St. Louis Late MarketA very superior late sort. Lately introduced by P. S. Co., St. Louis. Has been grown with great success by market gardeners throughout the entire country, and for a late Cabbage certainly has no superior. Pkt., $10 \mathrm{c}$; oz., $50 \mathrm{c}$; $1 / 4$ 1b., $\$ 1.50 ; 1 \mathrm{~b} ., \$ 5.00$, postpaid.

\section{Maninioth Red Drum-} head-The best Red Cabbage. Largest and surest heading. Its handsome appearance, solidity and delicious flavor make it very desirable Cabbage for those who prefer the red varieties. Pkt., $5 c$; oz., 25c; $1 / 4$ 1b., 60c; 1b., $\$ 2.00$.

Red Dutch-Used almost exclusively for salad or pickling. Hardy, an excellent keeper. Is slow to mature. Should be transplanted rather early, in a good heavy soil, to obtain perfection. Pkt., 5c; oz., $25 \mathrm{c} ; 1 / 41 \mathrm{~b}$., $60 \mathrm{c} ; 1 \mathrm{~b} ., \$ 2.00$.

St. Louis Late Market (Short Crop).

Bridgeport Drumhead-An excellent and exceedingly popular sort, is noted for its solidity of head, extremely large size and the fact that it is little inclined to burst or rot in the field. Pkt., 5c; oz., $20 \mathrm{c} ; 1 / 4$ 1b., 60c; $1 \mathrm{~b}$., $\$ 2.25$. Cabbage.

SPECIAL OFFER-For only 20 c we will send postpaid one packet each of any five varieties of

Try our Mixed Lawn Grass for a good lawn. Put up in one pound cartons; per pound, $2.5 \mathrm{cts}$,; per bushel in bulk, $\$ 3.50$. 


\section{CARROTS FOR TABLE USE.}

CULTURE.-Carrots for early crop should be sown as early in the spring as the condition of the ground will permit, in drills I6 to I 8 inches a part, corered lightly, and if too thick, thin to about 3 inches in the row. Sow 3 to 4 pounds to acre or I ounce to Ioo feet drill. A light soil preferred.

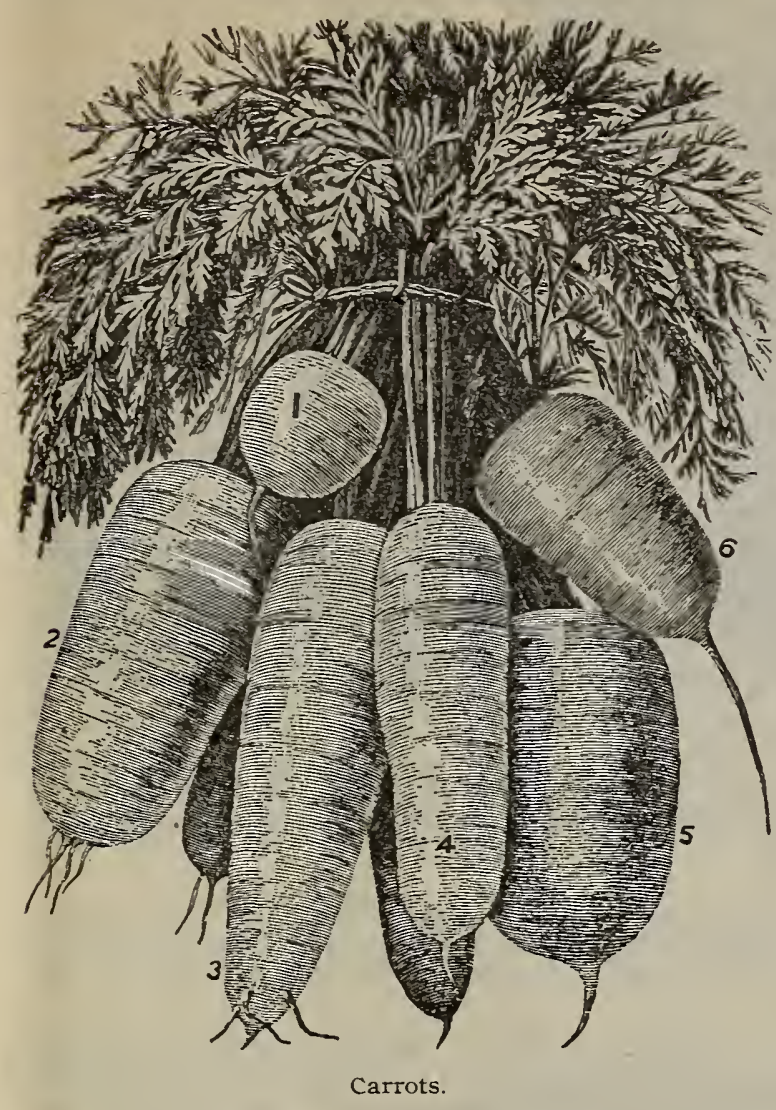

Extra Early French Forcing.-The earliest rariety in cultivation. Roots almost round. Tops small. Color an or ange red. Pkt., 5c: oz., 10c; 1/4 1b., 25c; 1b., 75c.

Guerande, or Ox Heart-A very valuable variety for family or market use. Handsome in shape. Intermediate in size, but rery early. Rich orange color and excellent in quality. Used also for feeding. Pkt., 5c; oz. $10 \mathrm{c} ; 1 / 41 \mathrm{~b} ., 20 \mathrm{c} ; 1 \mathrm{~b} ., 65 \mathrm{c}$.

Early Half Long Scarlet-Similar in shape to the Carentan. Color bright scarlet, becoming yellow in the center, but without core. This is a rery fine table sort. Pkt., 5c; oz., 10c; 1-4 1b., 20c; 1b., 65c.

Early Half Long Carentan-Very fine bunching Carrot, a new scarlet variety without core, excellent for forcing, fine quality and perfect in shape. Plkt., $\bar{c}$; oz., $10 \mathrm{c} ; 1 / 41 \mathrm{~b} ., 20 \mathrm{c} ; 1 \mathrm{~b}$. . 60c.

Danvers Half Long-An old standard, all-purpose Carrot. Medium length, tapering to a point. Rich dark orange color and is without doubt the best general crop Carrot in cultivation. Pkt., 5c; oz., 10c; 1/4 1b., 20c; $1 \mathrm{~b} ., 65 \mathrm{c}$.

Chantenay-Particularly desirable for table use. Tops medium. Roots tapering slightly, but rery uniform. Flesh very sweet and tender and of an orange red color. Pkt., 5c; oz., 10c; 1-4 1b., 20c; 1b., 65 c.

We deliver free, direct to consumer, Vegetable Seeds, Flower Seeds and Bulbs, except where noted

Merchants not receiving our wholesale price card of Field Seeds, Grass Seeds, Onion Sets, etc., are requested to write for same. We give you prompt service and save you freights.

\section{CARROTS FOR STOCK.} acre.

Increase the milk of the cow. Improve the condition of the horse. One ounce will sow ioo feet of drill, four to six pounds the

Many experiments by enterprising and intelligent farmers and by agricultural colleges throughout the country have placed Carrots in the front rank of all root crops as a desirable and nutritious food for horses and cattle. Especially desirable for dairy cows during winter, adds both color and flavor to the butter.

White Belgian-Grows very large and somewhat abore ground, making it easy to harvest. Enormously productive. Pkt., 5c; oz., 10c; 1-4 1b., 15c; 1b., 40c.

Improved Long Orange-A rery well known and popular variety for late planting and winter use. This rariety will give your butter a rich color; also good for table use, roots being straight and smooth. A rich orange red. Pkt., 5c; oz., 10c; 1-4 1b., 20c; 1b., 60c.

Long Red Stump-Rooted-Very uniform in size. Flesh rich in color. Possessing high feeding qualities. Well adapted for heary soil. Especially recommended to stock breeders as a heavy cropper. Pkt., 5c; oz., 10c; 1-4 1b., 20c; 1b., 60c.

Intermediate Red-This variety grows roots from 10 to 12 inches in length and two to three inches in diameter at top, tapering gradually to the tip. Certainly the best main crop Carrot. We strong1y advise planting it. In favorable soil will grow clean and free from side roots. Pkt., 5c; oz., 10c; 1-4 1b., $20 \mathrm{c} ; 1 \mathrm{~b} ., 60 \mathrm{c}$.

\section{SPECIAL OFFER ON CARROT SEED.}

5-lb. lots, \$2.25, any selection, not prepaid.

Try our Mixed Lawn Grass. Per 1b. in 1 lb. cartons, 25c; per bushel in bulk, $\$ 3.50$. 


\section{CELERY.}

Each year adds to the popularity of this most healthful and beautiful vegetable. Nutty to the taste, crisp and solid, it is unequaled in striking appearance on the table or market stall. For early crop, seeds should be sown in hot-bed or cold frame, and transplant out doors when ground becomes warm. When plants are 4 or 5
inches high, plant in trenches, and as the plants grow draw the earth closely around them to blanch the stems. Never do this in wet weather, or the stems will rust. The outer stem stems will rust. The outer stem should be plill the trenches, as it will add to the thickness of the stalks. Celery in a rich, heavy and damp soil; during dry weather ample moisture must be provided. Plants should be taken up and stacked closely together with soil firm around the roots and kept in cellar or pit for winter use.

For general winter crop sow the seed during April in open ground. When plants are about 2 inches high they should be thinned or trans. planted to about 2 inches in the row; when 6 inches high, trim the tops carefully and transplant to trench or level ground to 6 inches in row. Transplanting should be done in cloudy weather. Never work among plants when wet.

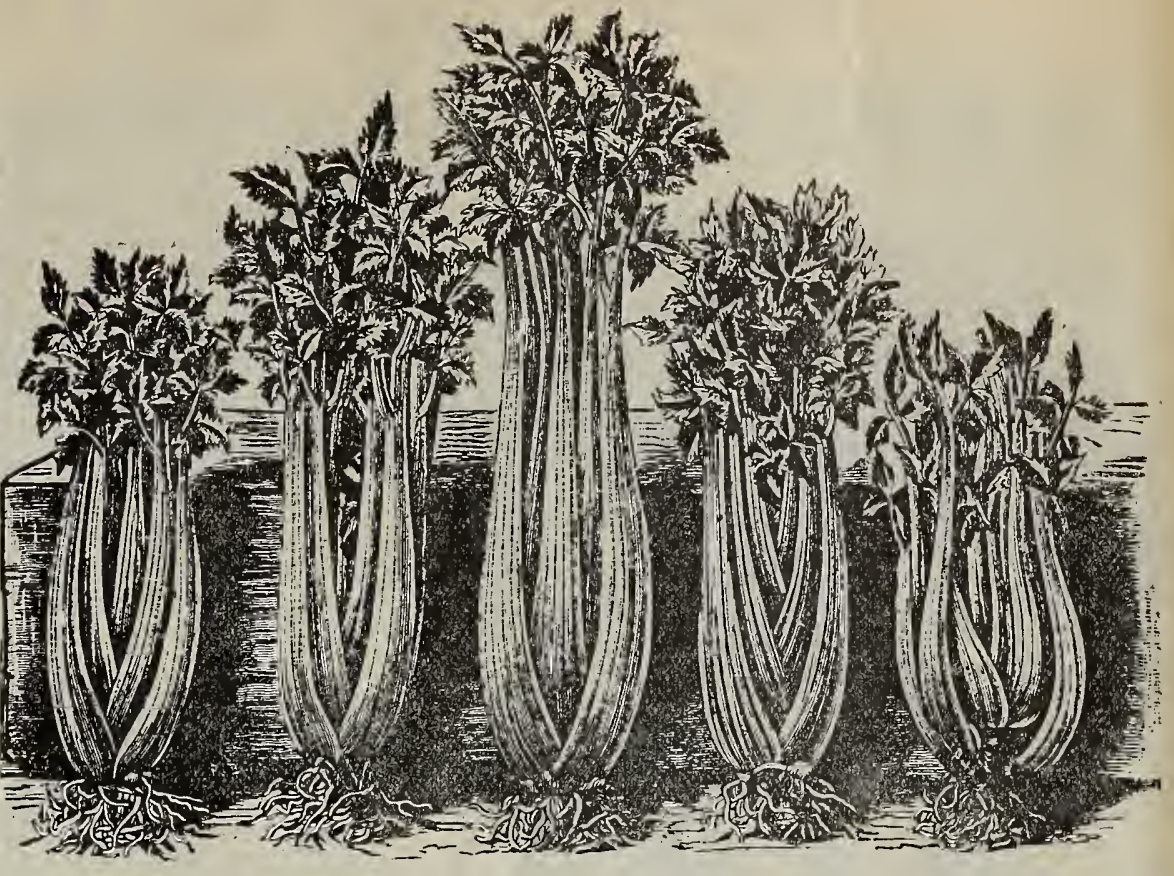

Dwarf Golden Heart-Very handsome variety, especially adapted to the home garden. When blanched, the heart is of a waxy color. An excellent keeper. Pkt., 5c; oz., 15c; 1-4 1b., 35c; 1b., \$1.25.

Boston Market-Medium size. Hardy sort. Dwarf and branching in habit. A great favorite in Eastern markets. Pkt., 5c; oz., 15c; 1-4 1b., 40c; 1b., \$1.50.

White Plume-This variety is more largely grown perhaps than any other. Besides combining all the good qualities of other varieties, the greater part of the stalk is naturally white, hence much easier to bleach. Also a good keeper, and is unsurpassed for both early and late use. Pkt., 5c; oz., 20c; 1-4 1b., $60 \mathrm{c} ; 1 \mathrm{~b} ., \$ 2.00$.

Golden Self-Blanching-A great favorite with the amateur gardener. Solid, brittle and of fine flavor. Has the merit of being almost self-blanching. Heart large and of a beautiful golden yellow color. Leaves are also of a golden color after the plant has been bleached, which adds greatly to its appearance. Pkt., 5c; oz., 20c; 1-4 1b., 60c; 1b., \$2.00.

Giant Pascal-A leading sort for winter use. Market gardeners recommend this variety for those who require one for very late use. Stalks are very 1arge and entirely stringless, unsurpassed in appearance and a vigorous grower. Pkt., 5c; oz., 15c; 1-4 1b., 35c; 1b., \$1.25.

Giant White Solid-The largest white Celery grown. Suitable for southern sections of the country. Free grower. Pk., 5c; oz., 15c; 1-4 1b., 50c; 1b., \$1.75.

Pink Plume-Very ornamental. Stalks beautifully tinged with pink. Similar in quality and habit to the White Plume. Pkt., 10c; oz., 25c.

\section{CELERIAC, OR TURNIP=ROOTED CELERY.}

Large Erfurt-Used for flavoring soups and meats. Pkt., 5c; oz., 25c.

CRESS, OR PEPPER GRASS.

Sow thickly in very shallow drill. Cover slightly. A hardy perennial, remaining green nearly throughout the year. Is ready for use very early, and, when cut young, makes a delicious salad.

Upland Cress-A very desirable substitute for Water Cress. Pkt., 10c.

Water Cress-Must be grown in moist places, and better in shallow, clear, running water. Pkt., $10 \mathrm{c} ;$ oz., 35c; 1-4 1b., 90c.

\section{CHICORY.}

Sow one-half inch deep in drills one-half foot apart, and cultivate same as Carrots. One ounce for 100 feet of drill. Roots, when dried, are mixed with or used as a substitute for coffee. Young leaves make excellent greens. Pkt., 5c; oz., 10c; 1-4 1b., 30c; 1b., 75c.

\section{CORN SALAD, OR FETTICÚS.}

To be served same as Spinach. Cultivated same as Lettuce. May be sown in August or September and protected from cold by covering. Furnishes an early salad in spring. When sown in spring, grows rapidly and is soon ready for use. Pkt., 5c; oz., 10c.

Try our Mixed Lawn Grass for a good lawn. Put up in one pound cartons; per lb. $25 \mathrm{c}$; per bushel in bulk, $\$ 3.50$. 


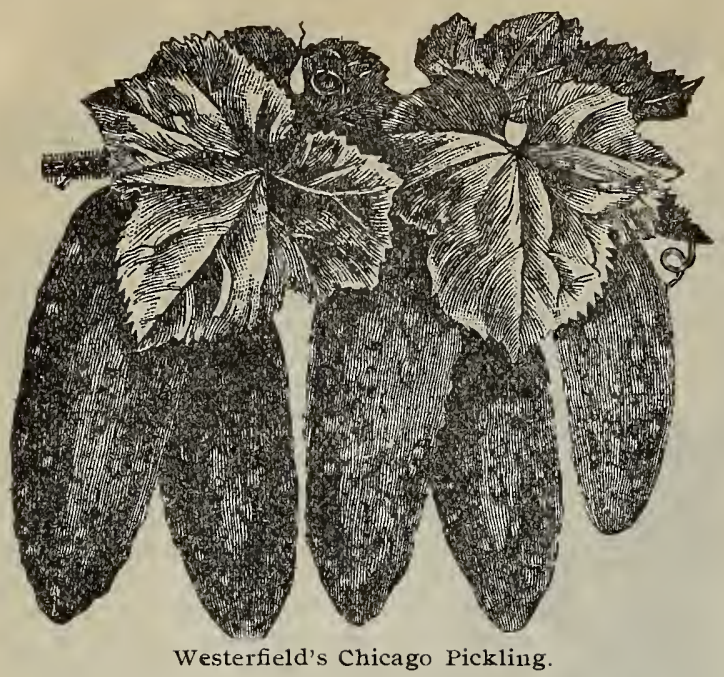

Evergreen White Spine-Straight, full at ends, and of a deep, handsome green color in all stages of growth. Resists drouth remarkably well and bears longer than most varieties and makes a very fine pickle.

Boston Pickling-Cultivated throughout the country for market use and for bottle pickling.

Westerfield's Chicago Pickling-Has been grown for some years very extensively by pickle manufacturing concerns, and is without doubt the best pickling Cucumber in the world, retaining its color under all conditions

Gherkin-Grown exclusively for fancy pickles. Fruit is oval shape and covered with prickly spines. Plkt., 5c; oz., 15c.; 1-4 1b., 45c; 1b., \$1.25,

Do not forget that we offer liberal discounts on Seeds in Packets. See page 3 and order sheet.

\section{SWEET CORN.}

Sweet Corn requires a rich, alluvial soil and should be worked thorouchly before planting to get the best results. Plant in rows three feet a part and about three feet in the rows. Early varieties may be planted from May ist until last of July. Cover lightly. A superb vegetable One of the most importatt crops grown. Fine for drying as well as for summer table use.

New Farly ChampionA new variety and without question the earliest large Sweet Corn in cultivation. Introduced only a few years since, but at once assumed its place in the front rank as a leader among the early sorts. Medium-sized white cob. Kernels very sweet, tender and full of milk, Its superior qualities attained by scientific selection at once commend it to market gardeners and amateurs as a very desirable variety. It ripens a little earlier than the Crosby's Early, with an ear somewhat longer than the Concord. Pkt., 10c; pt, 20c; qt,, 35c, postpaid. Pk, $75 \mathrm{c}$; bu., $\$ 2.00$, freight or express.

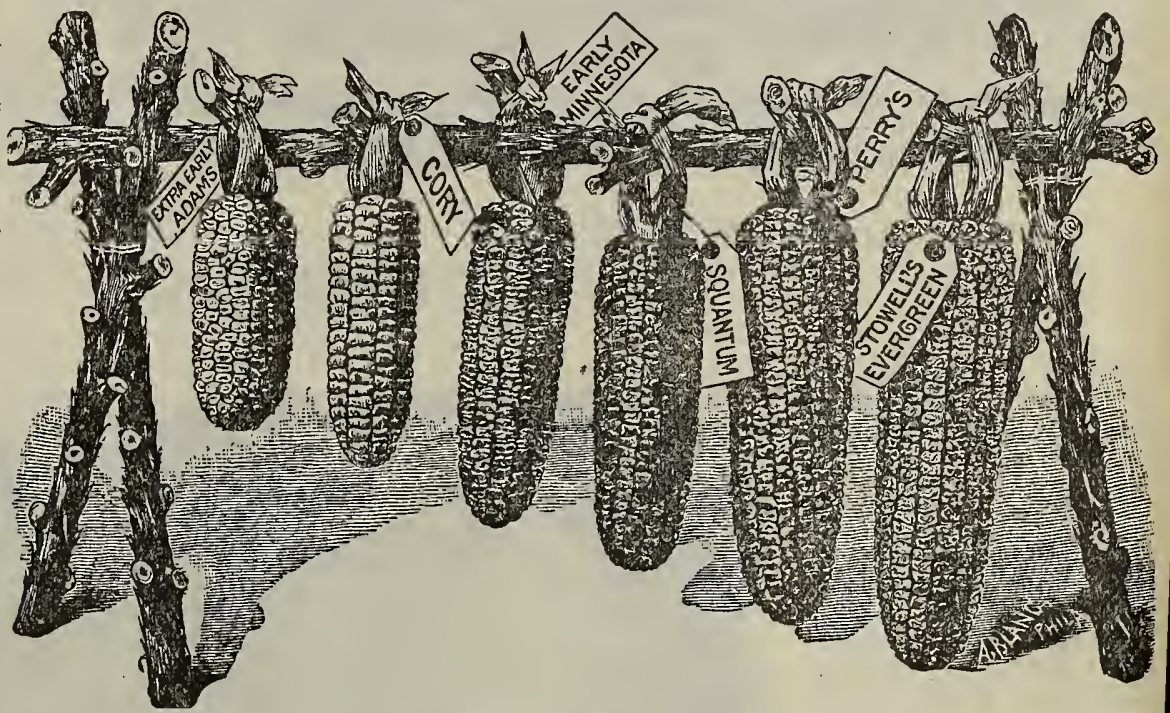

Our Sweet Corn is all Eastern grown and of superior quality.

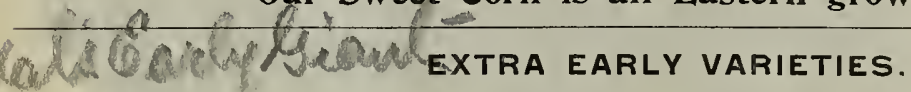

EXTRA EARLY RED COB CORY.-An extra early and old market variety, fair size ears EARLY WHITE CORY-Similar to Red Cory, but white cobs and kernels EXTRA EARLY ADAMS-Not a Sweet Corn, but grown largely for early market use EARLY MINNESOTA-Almost as early as Cory, dwarf in habit, ears white CARLSBY'S EXTRA EARLY E Ears fair sized and of excellent quality. BONANZA-As early and larger than Crosby's; a favorite with the trucker

SHAKERS' EXTRA EARLY-Iarge, early and productive, a11 all-purpose sort, unsurpassed in any particular.

\section{SECOND EARLY SORTS}

PERRY'S HYBRID-A rather large growing variety, fine quality, highly prized by market gardeners and canners. MA M T SUG MOORE'S CONCORD-Ears large and well filled, very sweet and fine flavored BLACK MEXICAN-Blue black in color and the sweetest Corn in cultivation

\section{LATE VARIETIES.}

STOWELL'S EVERGREEN-This sort is perhaps more largely planted than any other variety, being old and a standard for many years; a favorite with market gardeners and canners. It is exceptionally tender and of a rich sugary flavor, remaining in an edible condition for a long time; large ears;

COUNTRY GENTLEMAN, OR SHÖE PEG-Is becoliling very popular and well known possesses a great many superior qualities, very deep grain, sinall cob, ears good size and will prođuce three to four to the stalk

LATE MAIVIMOTH-The largest of all: a file market variety

EGYPTIAN-A large variety, resembling the Evergreen. broad flat grain; a genuine Sweet Corn.

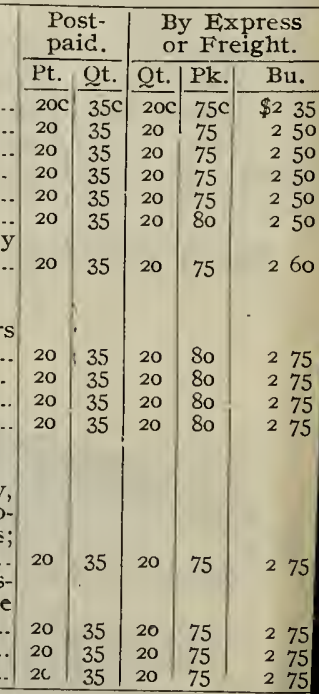

Write for special prices on Sweet Corn for Fodder.

We deliver free, direct to consumer, Vegetable Seeds, Flower Seeds and Bulbs, except where noted. 


\section{Pop Corn For Profit.}

The demand for Pop Corn is so great that we consider it of sufficient importance to make a special feature of it in our list. In the past only grown by the boys on the farm in some out-of-the-way place, and considered as of no special value-simply something to amuse the children. A rery mistaken idea. It always commands a good price, and each year brings an increased demand

Should be planted separately and apart from other Corn in order that it may be pure. Cultivate same as other corn. Being smaller, it occupies less space. We are always in the market for pure stock.

Monarch White Rice.-The best white variety for all purposes and commands at all times the highest market price. Produces three to six ears to the stalk, or about 1,500 pounds to the acre. It is used largely for street popping, and we think if you will try an acre you will find it a very profitable crop.

Queen's Golden-A large-eared sort. Very large when popped and exceedingly tender. Grows about six feet in height. Bears three to six ears to the stalk; making good fodder crop, besides being profitable for the grain. Next to White Rice, is the biggest seller.

New Striped Rice.-A very handsome and attractive variety in Pop Corn. Color white, each keruel is striped with bright crimson. Ears good size and well filled.

Maple Dale Prolific-The most productive Pop Corn in Cultivation, bearing five to twelve ears to the stalk. Pops very large and tender, and is rapidly gaining faror with the trade.

Prices on any of the above varieties, postpaid: Pkt.. 5c; pt., 15c; qt., 25c, Write for special prices on large quantities.

\section{COLLARDS.}

Largely used as greens, more especially in the South. They are a form of Cabbage, bearing new leaves as fast as the old ones are pulled off. Pkt., 5c; oz., 10c; 1/ 1b., 30c; 1b., \$1.00.

\section{CHERVIL.}

A plant used in tlaroring soups and salad. Very fine flaror and perfume. Pkt., 5c; oz., 15c.

KOHL-RABI.

A very curious regetable. Belongs to the Cabbage family. Somewhat partakes of the faror of Cabbage and Turnip combined. Flesh very delicate and delicious. Cultivate similar to Cabbage, taking care not to place the plants deeper than they stood bined. Flesh very delicate and delicious. Cultivate similar to Cabbage, taking care not to place the plants deeper than
in the hot-bed. Has a turnip-like swelling of the stem above the ground. When young, very appetizing and pleasant.

Early White Vienna.-Small bulb. Early. Flesh white and rery tender. Pkt., 5̌c; oz., 15c; 1/4 1b. $+\bar{x}$; $1 \mathrm{~b} ., \widehat{\$} 1.25$.

New Smooth Purple.-Short leares. Similar to White Vienna, except in color, being a rery rich purple. Pkt., 10c; oz., 35c; 1/4 1b., \$1.00, prepaid.

\section{EGG PLANT.}

Seeds should be sown in hot-beds in March or early April. Transplanted about June Ist, $21 / 2$ or 3 feet in the row. The plants are large and vigorous; leaves large and of a light green shade. Requires a rich, deep soil and will thrive best in a damp, shaded spot. Fruit large and oval. Flesh white and tender.

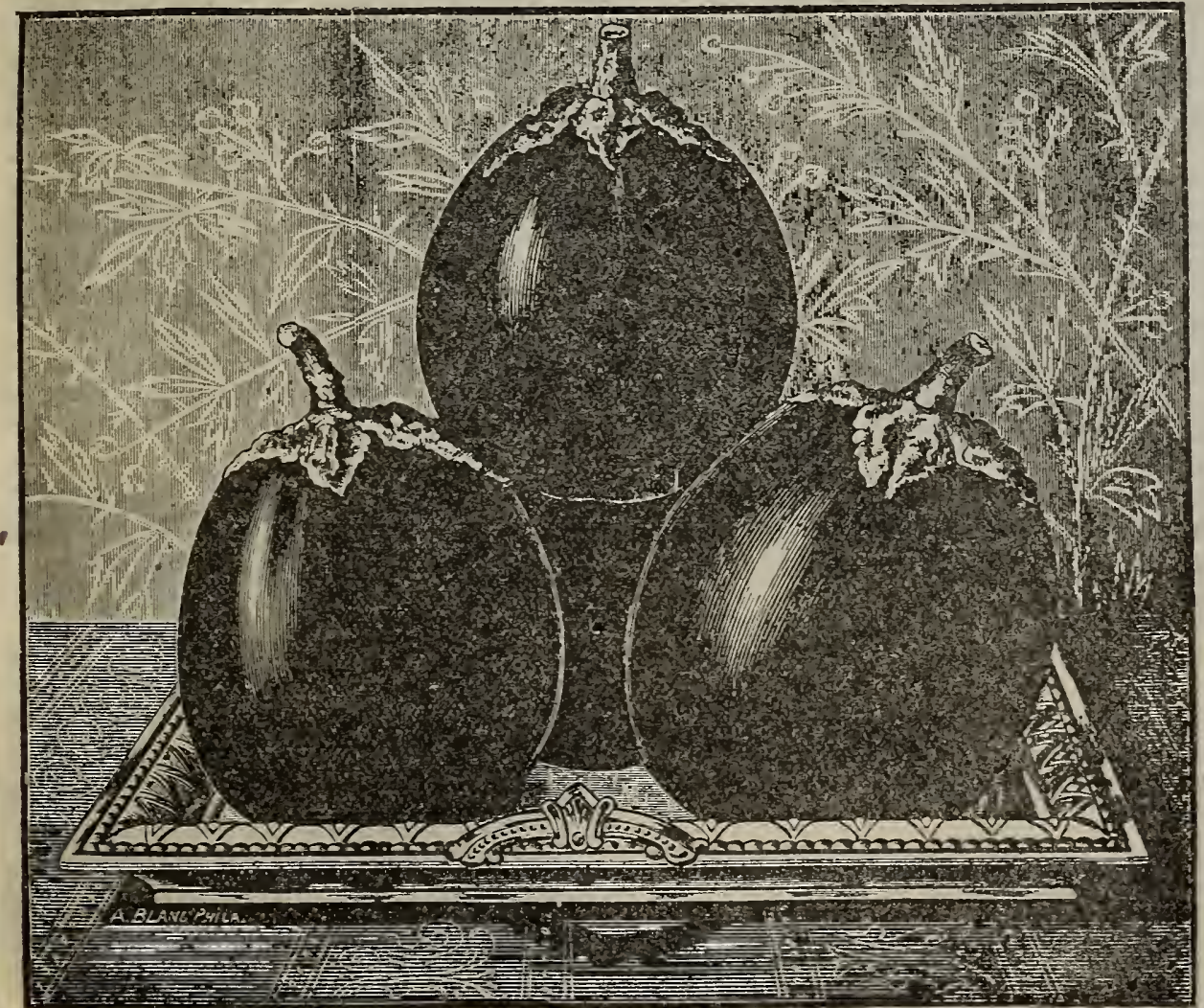

Tew York Improved-A large purple fruit, early, ovalshape, and of a fine quality, never becoming red or yellow. The most showy as well as the best seller of all varieties. Pkt., 5c; oz., 25c $1 / 4$ 1b., 65c; 1b., $\$ 2.50$ postpaid.

Early Long Purple-Hardier than other sorts. Stands drouth and insects well, and is certainly well adapted to this section. Flesh, white and very delicious. Pkt., 5c; oz., 25c: $1 / 41 b ., 65 \mathrm{c} ; 1 \mathrm{~b} ., \$ 2.50$ : postpaid.

Try our Mixed Lawn Grass for a good lawn. Put up in I lb. cartons, per lb., 25 cents; per bushel in bulk, $\$ 3.50$. 


\section{ENDIVE.}

The leaves of this plant make a delicious autumn salad. When almost full grown the outer leaves are tied together in order to bleach the center. Should be carefully lifted late in the fall with a ball of dirt attached and placed close together in the cellar. One ounce will sow about I5o feet of drill. Sow late in July for winter use.

Mammoth Green Curled-A beautiful and valuable variety. Superior to any other. Grows fifteen to twenty inches in diameter. Leaves are very crisp, tufty and full. Extremely hardy, equally suitable for spring, summer or autumn planting. Pkt., 10c; oz., 25c; 1/4 1b., 60c; 1b., $\$ 2.00$.

Everwhite Curled-Midrib yellow, leaves almost white, large size. A very sightly variety. Pkt., 5c; oz., 15c; 1/4 1b., 35c; 1b., $\$ 1.25$.

Green Curled-The well-known old sort. Dark green curled leaves, tender and of good flavor. Pkt., 5c; oz., 15c; I/4 1b., 35c; 1b., $\$ 1.25$.

\section{KALE.}

KALE is very easily grown and much hardier than any Cabbage. Will stand the winter with little protection. A slight touch of frost improves the flavor wonderfully. Particularly fine for winter and early spring greens. Sow in the spring and as late as September.

Dwarf German Greens-This variety grows to be very large. Leaves plain in the center, curled edges, of dwarf spreading habit, very hardy. Extensively grown for winter greens. Pkt., 5c; oz., 10c; $1 / 4$ 1b., 25c; 1b., 75c.

Dwarf Green Curled Scotch-A beautiful curled sort. Leaves bright green. Will stand almost zero weather. Pkt., 5c; oz., 10c; 1-4 1b., 30c; 1b., 80c.

Tall Green Curled Scotch-Very hardy. Grows twenty-five to thirty inches in height, producing an abundance of very dark green leaves, which are beautifully curled. Pkt., 5c; oz., 10c; 1-4 1b., 30c; 1b., 90c.

\section{LEEK.}

Belongs to the Onion family, and by many preferred to that vegetable. It has a very agreeable flavor and is used for soups stews, etc; Both the leaves and bulbs are used, Sow seeds in bed or drills. When six to eight inches high, transplant to rows one foot apart, four or five inches in the row.

American Broad Leaf-This variety is perhaps more largely used than any other. Strong grower with very broad leaves. Pkt., 5c; oz., 10c; $1-41 \mathrm{~b} ., 30 \mathrm{c} ; 1 \mathrm{~b} ., \$ 1.00$.

Giant Carentan-Immense size. Broad leaves. Very hardy. Pkt., 5c; oz., 15c.

\section{LETTUCE.}

Wherever you find a garden you will find Lettuce, possibly more universally used that any other vegetable, especially in the spring. Served in various ways, and to be thoroughly appreciated should be fresh and crisp. Will thrive in ordinary garden soil, but should be of rapid and vigorous growth. Sow in hot-bed early, transplanting to open ground eleven or twelve inches apart. Sowings at short intervals should be made to secure good L tettuce during the season. One ounce will sow too feet of drill.

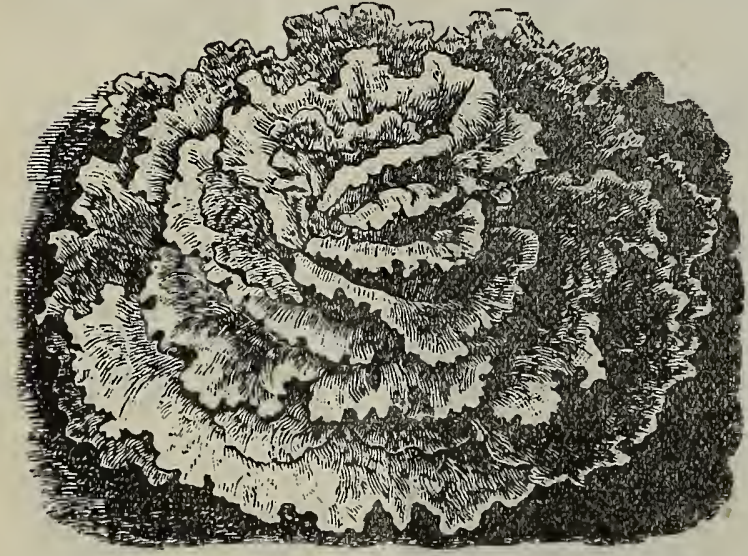

Early Curled Simpson.

Early Curled Simpson-A good forcing sort. White-seeded, resembles Black-Seeded Simpson. Early. and an old favorite with all.

Black-Seeded Simpson-An old standard, used largely for forcing and for early and late out-door culture. Stands heat and drouth well. Leaves large, thin and very tender, of a light green color, slightly curled. A fine sort for all seasons and all purposes.

Early Curled Silesia-Extra early. A fine variety for early out-door planting. Quality is excellent.

Hanson-A heading variety. Outside leaves being dark green, while the inside are white, very tender and crisp. One of the best mid-summer varieties grown.

White Summer Cablbage-A head Lettuce of remarkable quality. Forming a fine solid head of good size and will withstand heat and drouth, making it a good late variety.

Boston Market-This variety can be planted so close as to make it well adapted for glass culture, grows very compact and forms fair-sized heads slightly tinged with red on the edges of the leaves. It is also one of the best varieties for out-door culture. Pk., $5 \mathrm{c} ; 0 z ., 15 \mathrm{c} ; \frac{1}{4} 1 \mathrm{~b} ., 25 \mathrm{c} ; 1 \mathrm{~b} ., \$ 1.00$, postpaid.

Denver Market-Used either for forcing or open ground. An early variety, forming heads which are solid and of a beautiful light green color, curled somewhat like Savoy Cabbage, and always crisp and tender.

Grand Rapid Forcing-Adapted for green-house culture, being of quick growth, and remaining in good condition or some days after being fully matured. Largely grown for shipping. Plant is upright, and forms a somewhat loose, large head, light yellowish-green leaves, considered by market gardeners the best forcing variety in cultivation. Pkt., 5c; ol., 15c; $\frac{1}{4} 1 \mathrm{~b} ., 30 \mathrm{c} ; 1 \mathrm{~b} ., \$ 1.00$ :

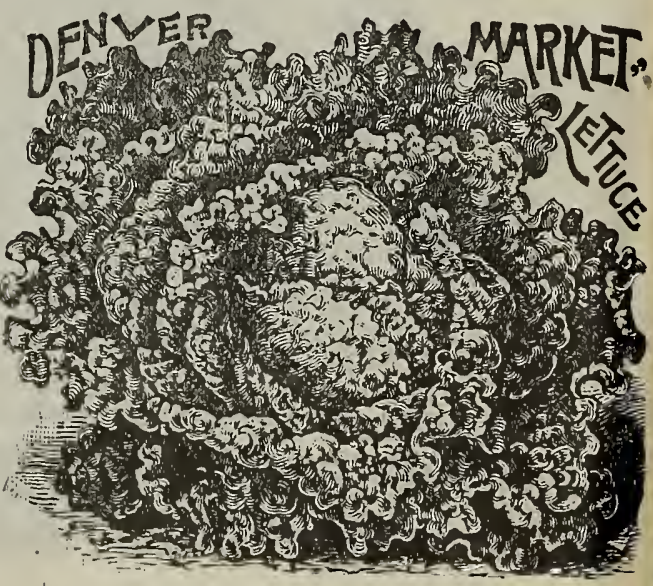



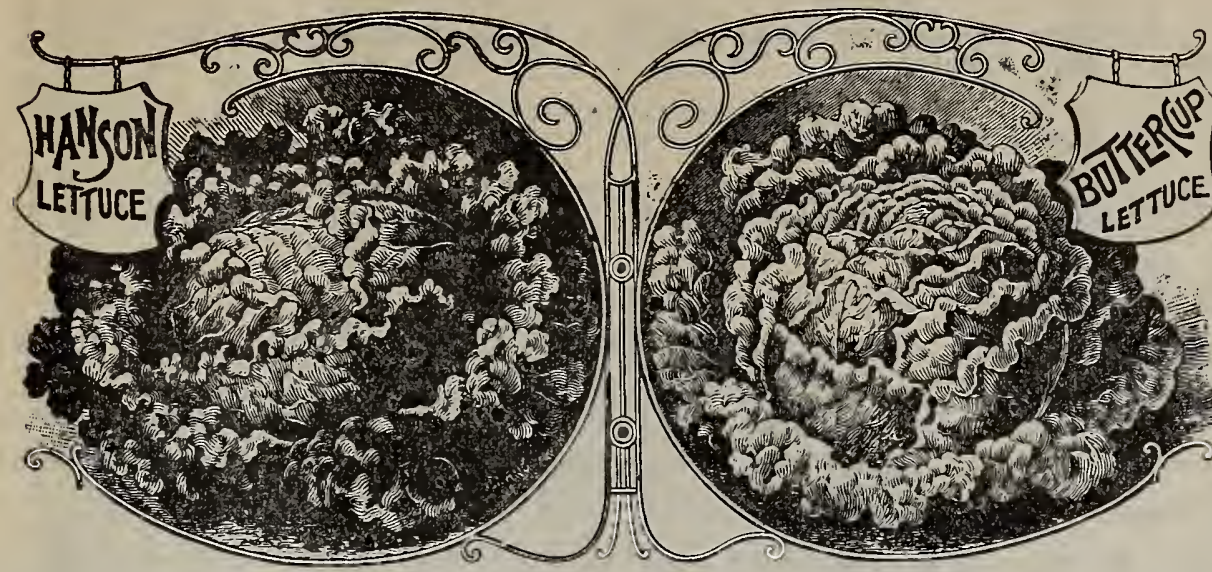

Prize Head-A head Lettuce. Outside leaves of a reddish brown color. Hardy and withstands the heat and drouth well. Runs to seed slowly.

Grolden Ball Buttercup-An imported variety, being distinct from all oth ers. Of a golden yellow, retaining its color throughout the season. Attractive in appearance and very sweet and tender.

New Trianon Cos--The finest of all the Cos sorts. Leaves when bleached are stiff like Celery stalks and

can be eaten in the same manner.

Prices, unless otherwise noted, postpaid: Pkt., 5c; oz., 10c; 1-4 lb., 30c; lb., 90c. Packed, any five varieties, $20 \mathrm{c}$.

\section{Petersiol MUSKMELONS.}

To get the best results, select a waru, rich, sandy loam, thoroughly work the soil, Make hills six feet apart each way. Use in each hill a few shovelfuls of well-rotted manure. Seeds should never be planted until settled warm weather. Plants are very sensi tive and liable to be injured by frost. Should the vines grow rapidly and too luxuriant, may be pinched off when three or four feet in length. Also if the fruit should set too thickly, thin when young. This will hasten ripening and also inerease the size and qual ity of the Melons. Cultivate often until the vines interfere.

Rocky Ford-This is unquestionably one of the best early Melons for market gardeners and shippers. Oblong and somewhat similar in appearance to the Netted Gem. Skin green and finely netted. Color of flesh light green, but very sweet and delicious. Owing to its good qualities, it is large$1 y$ cultivated, being hardy. A good keeper and best of shippers. Pkt., 10c; oz., $15 \mathrm{c} ; \frac{1}{4} 1 \mathrm{~b} ., 30 \mathrm{c} ; 1 \mathrm{~b}$., $75 \mathrm{c}$.

Melrose-One of the best Melons of the home market. The flesh is thick, solid and of a light green color, very sweet and delicious. Pkt., 5c oz., 10c; $\frac{1}{4}$ 1b., 20c; 1b., 60c.

Jenny Lind.Small and somewhat flattened at the ends. Early, fine netted, flesh green, sweet and delicious

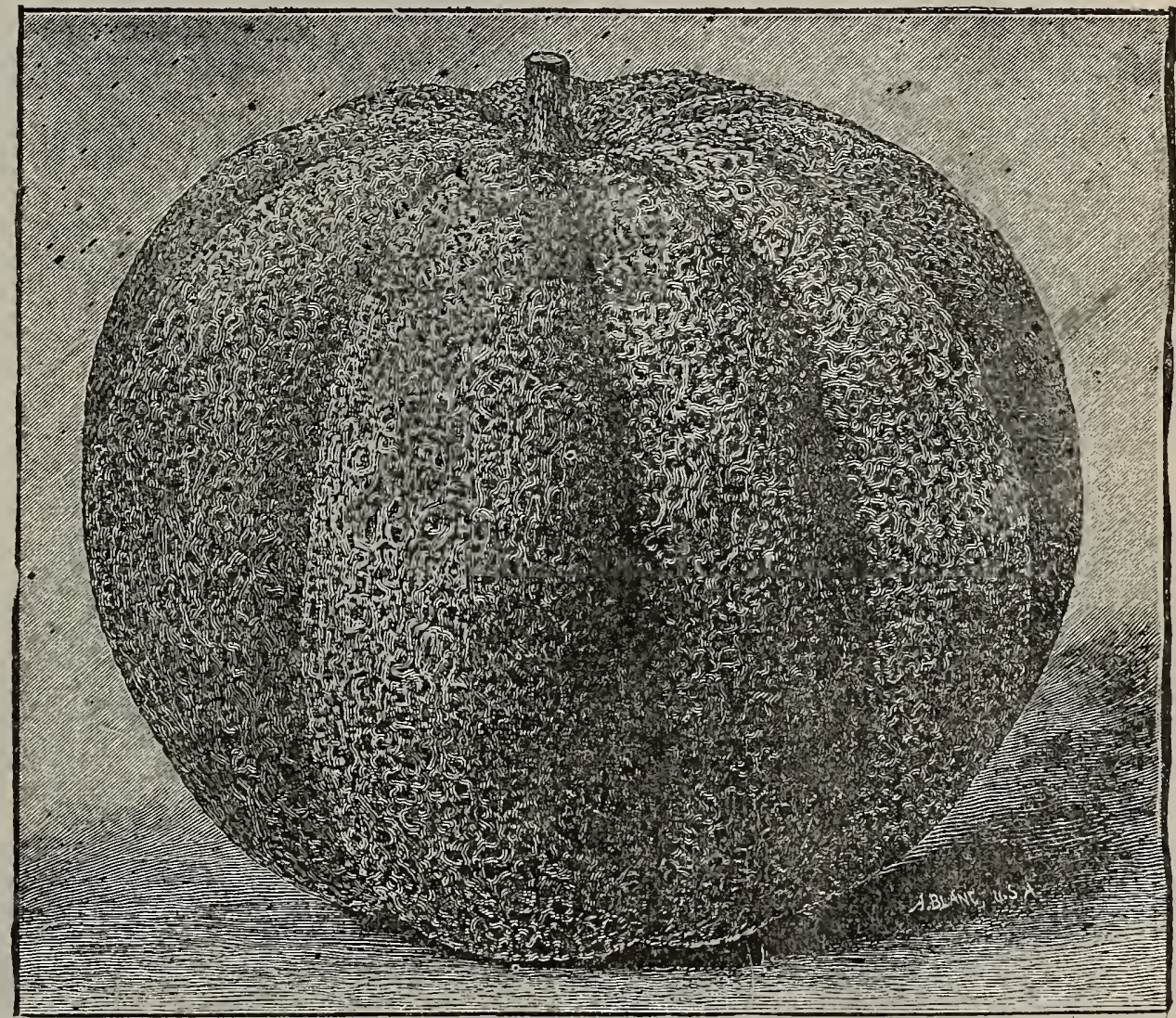

Chicago Market Muskmelon

Large Hackensack-Somewhat later than the Early Hackensack. Large and of a very uniform size, very productive. Flesh green and of a very fine flavor.

Champion Market-Globular in shape. Very heavily netted, growing to a good size. Averase weight about five pounds. A second early variety and very popular, because of their fine flavor and from the fact that they resist sunburn extremely well. It is especially desirable as a shipper and for the home garden.

Emerald Gem-A most delicious small Melon, extremely thin rind. Flesh of a beautiful salmon olor, or almost red. Flavor unexcelled.

Miller's Cream-Skin is slightly netted, dark green in color. Owing to its being a heavy cropper and the flavor of the flesh, this old-time favorite holds its own.

Improved Green Nutmeg-This is perhaps the greatest general crop melon on the Market. Flesh light green and beyond question the surest cropper and most productive sort in cultivation, 
Early Green Nutmeg-A rather small green-fleshed variety. Dark green rind, well netted, ribb and somewhat globular in shape. Extra early.

Golden Netted Gem-One of the very best varieties; though rather small, is very producti Flesh light green in color, and of fine flavor.

Extra Early Hackensack-Ripens fully ten days ahead of the old Hackensack, which it much sembles. A good shipper. Fruit large, round and deeply netted. Where an extra early Melon is require it is very desirable.

Montreal Mar'ket-Large size. Flesh very thick and fine flavor.

Baltimore, or Acme-Heavily netted. Deeply ribbed. Somewhat oblong in shape. Flesh gree

Chicago Market-A very large Nutmeg variety. Uniform size and shape. Well ribbed. Fine netted. Flesh green, very juicy and sweet, delicious flavor. Seed cavity very small. Seldom cracks or ro

Bay View-Green flesh. Large and productive. Sometimes attaining the weight of fifteen pound

Banana-Has the appearance and smells like a Banana. Quite a novelty.

Paul Rose-A new salmon-fleshed variety, especially adapted for fancy shipping trade. Rath sma11. Oblong in shape. Ribbed and netted. Possesses excellent table qualities in every way, becomin a general favorite. A cross between the Emerald Gem and Osage. Pkt., 10c; oz., 20c; $\frac{1}{4} 1 \mathrm{~b} ., 50 \mathrm{c}$.

Prices, unless otherwise noted, postpaid: Pkt., 5c: oz., 10c; 1-4 lb., 20c; 1b., $50 \mathrm{c}$.

\section{WATERMELONS.}

Never plant Watermelons on hard, poor soil. It requires a sunny, light, mellow soil, made very rich with well-rotted conpo Prepare the ground by deep cultivation and plant in hills eight to ten feet each way. Hoe of ten. Culture similar to Muskmel Somewhat hardier and more vigorous, and may be planted earlier. The largest Melons are obtained by pinching back the vines a removing all but a few when very small.

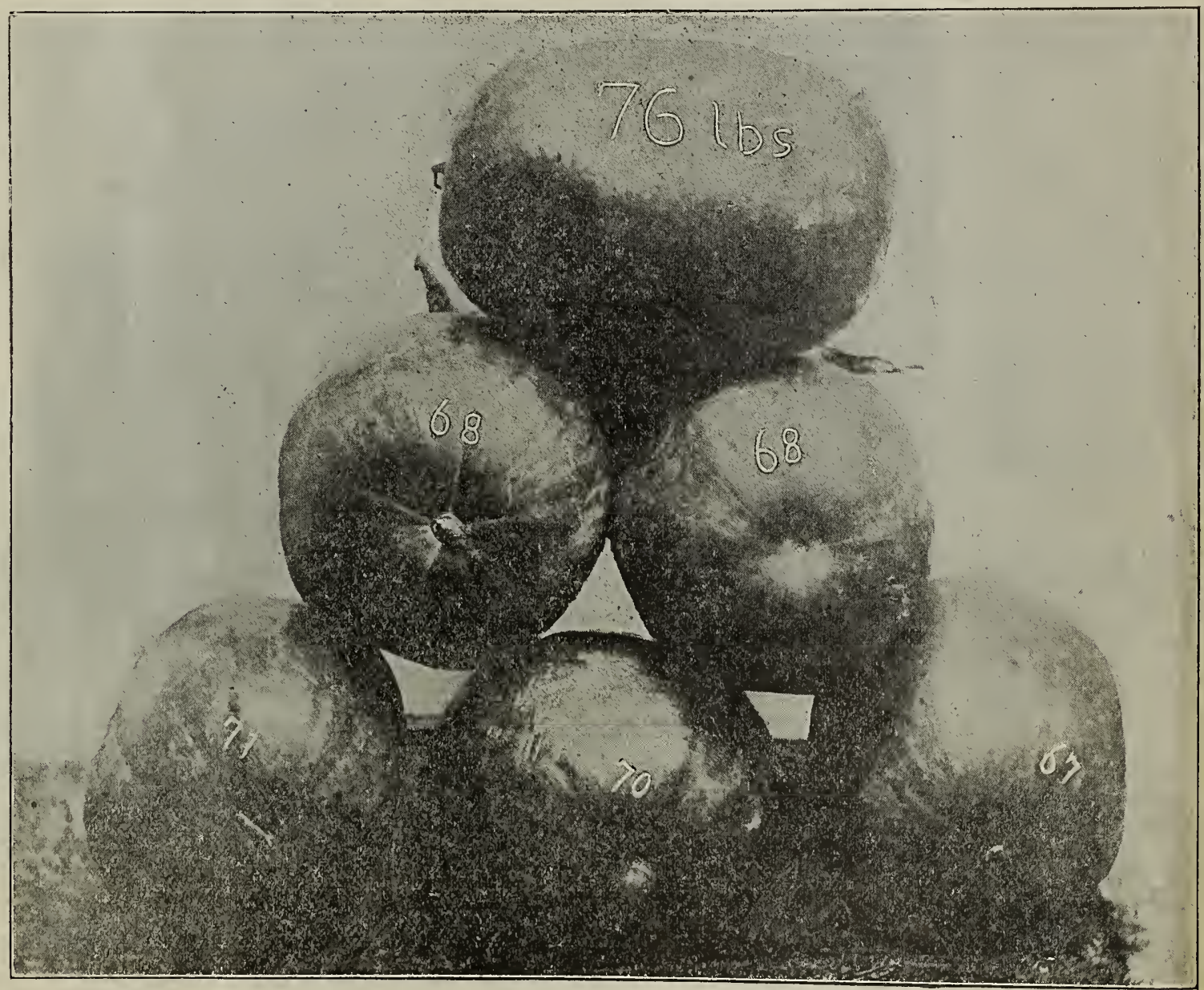

Six Melons of Girardeau's Triumph, Weighing 420 Pounds, in 1897.

Girardeau's 'Triumph-This new Melon, as a market sort and for shipment, is the best I have ev introduced. It is prolific, very early, and of a uniformly large size. It is a cross between the Duke Jon and Kolb Gem; has the fine, handsome appearance of the former and the fine shipping qualities of $t$ 1atter. The rind, like the Duke Jones, is of dark green color, with indistinct stripes of little lighter cold The seed exactly the same color as those of the Kolb Gem. As a table Melon, it is of much better flav than the Kolb Gen. The average size of the Melon is very large. I gathered from two and one-half act 2,418 Melons, weighing over forty pounds each. Comparatively speaking, there were no small Melons the vines at the time of harvesting seed.-W. M. GIRardeaU. 
Cole's Early--This variety has taken the place of most all the extra early sorts. Hardy, a sure cropper. Very thin rind. Quality of the flesh unsurpassed. Can hardly be called a good shipper, from the fact that it is exceedingly brittle. Cannot be recommended too highly for home use or early market gardening.

Phinner's Early-Very early. Medium in size. Flesh deep red and rery sweet. Rind thin. A very productive variety.

Sweet Heart--Fruit large, oval shape. Uniformly mottled light and dark green. Flesh bright red and rery sweet. Very popular.

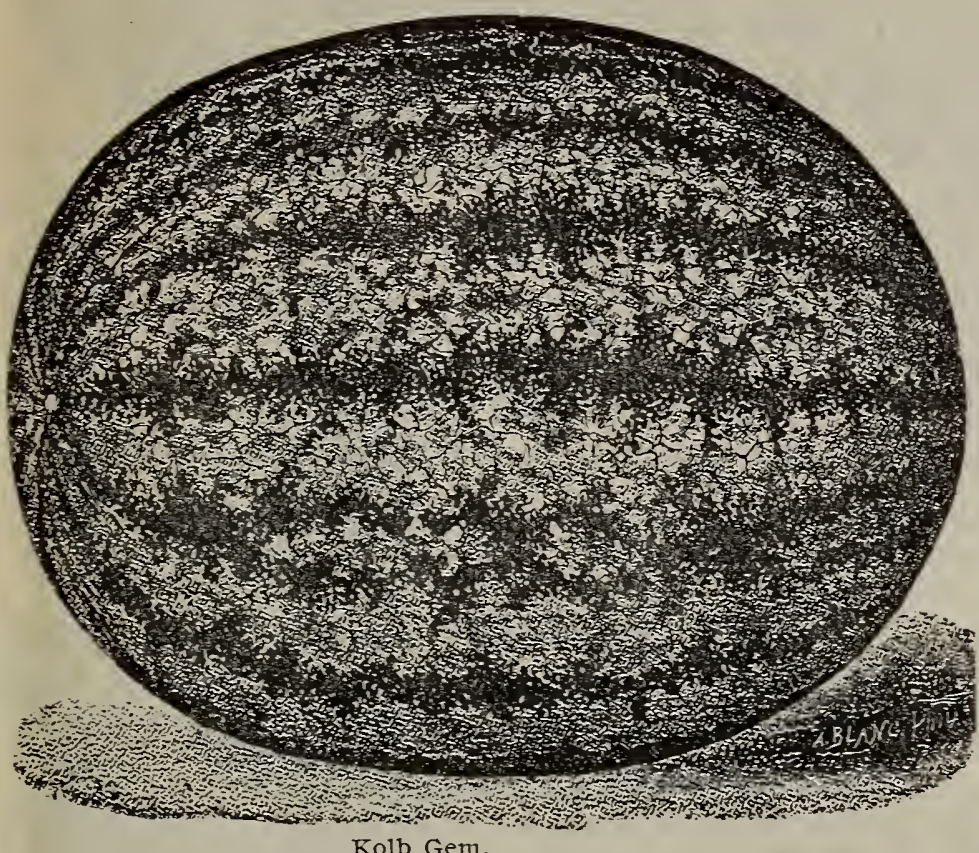

Mountain Sweet-A large rariety. Oblong in shape. Flesh red.

Dark Icing-Oblong in shape. Rind dark green. White seeded. Flesh dark red and of fine flavor. Extremely prolific and of good size.

Georgia Rattlesnake-A standard Southern sort. Fruit oblong and of good size. Striped light green, thin rind. Flesh deep scarlet and deliciously sweet, and a good shipper.

Florida Favorite - A rery fine table rariety. Oblong in shape. growing to a rery large size. Rind dark and striped light green. Flesh crimson.

Pride of Georgia-Striped light and dark green. Oral in shape. Flesh bright red and sweet. An excellent shipper. Of good size.

Ice Cream, or Peerless--A good allpurpose Melon of rigorous growth. Hardy and productive. Medium size. Mottled, light and dark green in color. Flesh a bright scarlet.

Kolb Gem--This rariety needs no description, having been grown largely by shippers for many years. Rind, though thin, is very tough, and will stand handling well. It is recognized as being the best shipper in the world. Our stock of this variety comes from one of the best growers in Florida and cannot fail to give satisfaction.

\section{Standard Sorts. \\ CUBAN QUEEN, BLUE GEM, BLACK DIAMOND, LIGITT ICING, OR GRAY MONARCH, JONES, \\ SCALY BARK, KENTUCKY WONDER \\ Prices, when not otherwise specified, postpaid: Pkt., 5c; ox., IUc; I-4 1b., 20c; $1 \mathrm{~b}, 65 \mathrm{c}$. \\ Write for special prices on large quantities. \\ OUR SPECIALTY: \\ Fine Southern Grown Melon Seed...}

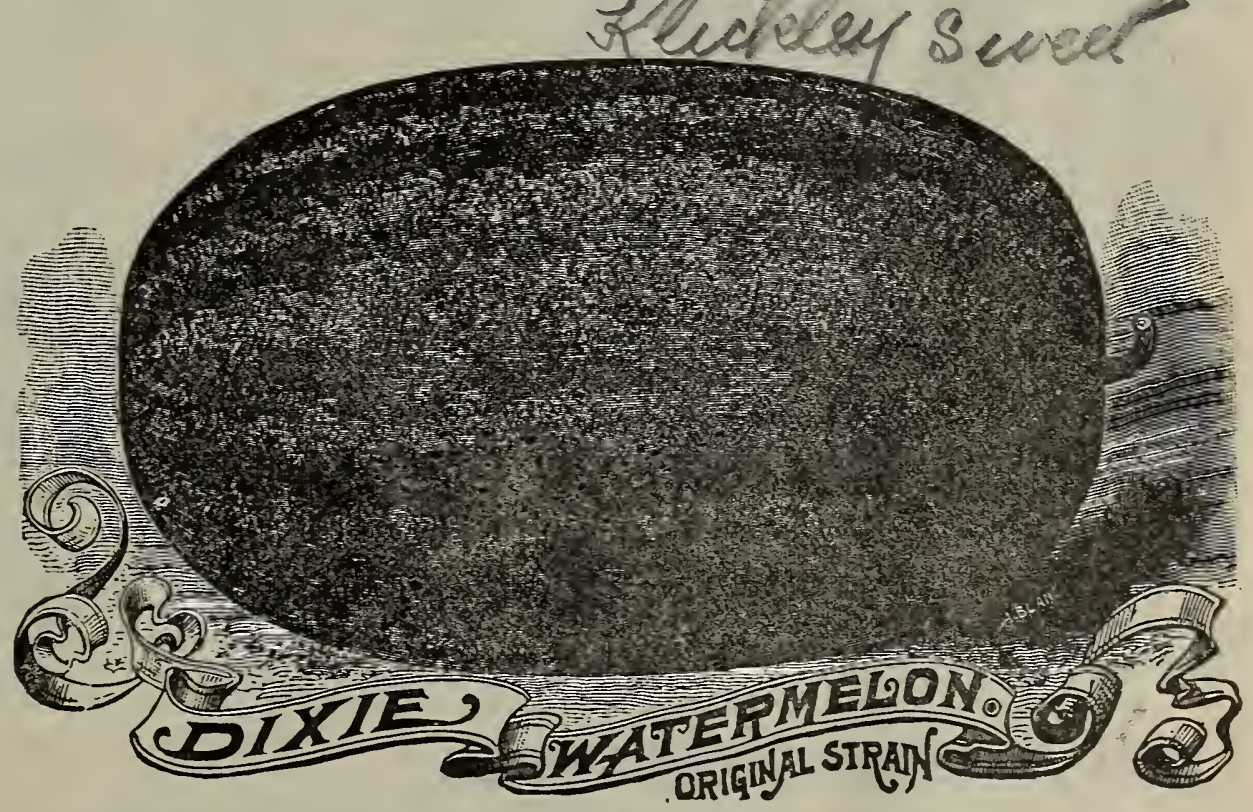

Improved Long Dixie-This rariety possesses all the good qualities of the Mountain Sweet and the Kolb Gem. Is early and a good shipper. Very productive. Handsome in shape and appearance. Flesh scarlet and rery sweet.

Wonderful Sugar-Very large, long, light colored, striped with green. Flesh red

Seminole-Extra early, rery productive. Large. Flesh red and delicious flaror.

Duke Jones-A new Melon which has attained great popularity and giren universal satisfaction whenever tried. Grows to immense size.

Alabama Sweet-A rery popular Melon in the West. A good shipper. Fruits well, Melons of good arerage size. Price per 1b., 50c; 1/2 1b., 30c; 1/4 1b., 20c.

Merchants not receiving our Wholesale Price Card of Field Seeds, Grass Seeds, Onion Sots, ote., aro roquestod to writo for samo. Wo givo you prompt sorvieo and save you froights. 


\section{MUSHROOMS.}

MUSHROOMS may be grown successfully and profitably during the winter and spring moitths in cellars or under benches in green-houses, wherever the temperature of 50 to 60 degrees can be maintained. The bed should be made from November to Febin green-houses, wherever the temperature of 50 to 60 de and it requires a bout two months for them to begin bearing. Prepare the ruary, according to the time the Mushrooms are wanted, and it requires about $\mathrm{two}$ months for them to begin bearing. bed by taking fresh, loose manure, free from staw or litter, and mix an equal bulk of loam fron an old pasture. Ke solidly. When the temperature is about go degrees, plant pieces of spawn the size of a walnut in holes 2 to 3 inches deep and 6 inches solidy. When the temperature is about $90 \mathrm{degrees}$, plant pieces of spawn the size of a walnut in holes 2 to 3 inches dith two inches of a part each way. Cover the holes, pressing the dirt solidly over the spawn. In about ten days cover the whole bed with two inches of
fresh loam. Protect with three or four inches of straw. Examine the bed often, so that it will not become dry. Should water be fresh loam. Protect with three or four inches of straw. Examine the
necessary, sprinkle with warm water, temperature about roo degrees.

English Spawn, in brick, per 1b., 20c; 10 1bs., $\$ 1.50$; by mail add 10c per $1 \mathrm{~b}$.

\section{MUSTARD.}

Sow to pounds to the acre. For salad and greens, sow broadcast early in spring. The seeds are also used for flavoring pickles pepper sauce, etc.

Yellow or White-Pkt., 5c; oz., 10c; 1/4 1b., 15c; 1b., 40c.

Brown or Black-Pkt., 5c; oz., 10c; 1/4 1b., 15c; 1b., 40c.

Southern or Chinese Curled-Especially valuable for fall sowing. Forms enormous bunches, and is fit for use until the plant attains a height of about two feet. The best Mustard grown. Pkt., 5c; oz., $10 \mathrm{c} ; \frac{1}{4} 1 \mathrm{~b} ., 20 \mathrm{c} ; 1 \mathrm{~b} ., 60 \mathrm{c}$.

\section{OYSTER PLANT, OR SALSIFY.}

Sow early in spring in drills twelve to fourteen inches apart. Thin to two inelies in rows. Cultivate like Parsnips. Can be gathered for winter use or let stand for use in spring.

Mammoth Sandwich Island-Grows to enormous size, being almost twice the size of the ordinary sort. Tender and delicious. Resembles large Parsnips. Pkt., 5c; Oz., 10c; $\frac{1}{4} 1 \mathrm{~b} ., 30 \mathrm{c} ; 1 \mathrm{~b} ., \$ 1.10$.

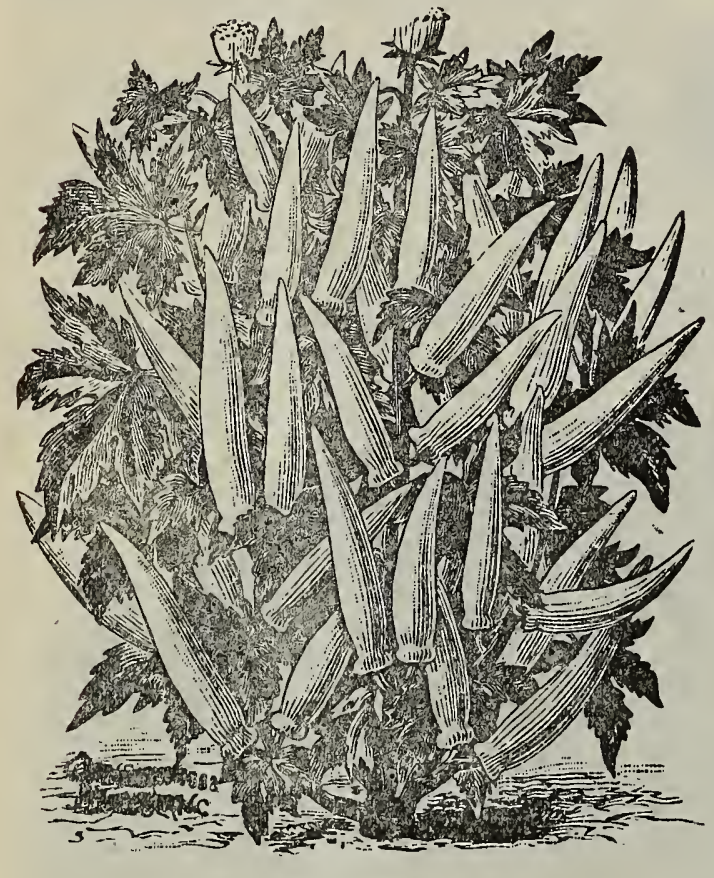

White Velvet Okra

\section{OKRA OR GUMBO.}

A very delicious vegetable. The young green pods make a healthful and nutritious soup; when pickled, are a fine salad. Easily grown. Sow after settled weather in rows three feet apart. Thin to ten inches in rows.

White Velvet-Round, smooth pods. Very prolific, bearing about twenty pods to the stalk. Very desirable for any purpose for which Okre is used. Pkt., 5c; oz., 10c; $\frac{1}{4} 1 \mathrm{~b} ., 20 \mathrm{c} ; 1 \mathrm{~b} ., 50 \mathrm{c}$.

Long Green, or Mammoth Long Pod-A distinct variety used by market gardeners, Pods green in color and of unusual length, largely used by canners and for winter use, Pkt., 5c; oz., 10c; $\frac{1}{4} 1 \mathrm{~b} ., 20 \mathrm{c} ; 1 \mathrm{~b} . .50 \mathrm{c}$, postpaid.

We deliver free, direct to planter, Seeds in packets with discounts that are liberal. Packets are large size.

Mixed Bird Seed in bulk, per pound Ioc, not prepaid. Special prices on large quantities.

Market gardners are invited to write for our special price list.

Write for prices on Bone and Cotton Seed Meai for fertilizers. Flax Seed Meal for stock.

If you only want one packet of Seeds, do not hesitate to order. Will take great pains to please you.

WE OFFER YOU NO UNTRIED NOVELTIES, BU'T RELIABLE, STANDARD VARIETIES, AND ARE CONFIDENT THAT WHAT YOU BUY FROMI US WILL PLEASE YOU.

\section{OUR PRICES ARE REASONABLE, OUR PACKETS ARE LIBERAL. OUR SEEDS ARE TESTED.}

With each 50c order you will get $65 c$ worth of Seeds in packets, postpaid.

Try our Mixed Lawn Grass for a good lawn. Put up in one pound cartons; per pound, 25 cts. ; per bushel in bulk, $\$ 3.50$.

Merchants not receiving our wholesale price card of Field Seeds, Grass Seeds, Onion Sets, etc., are requested to write for same. We give you prompt service and save you freights. 


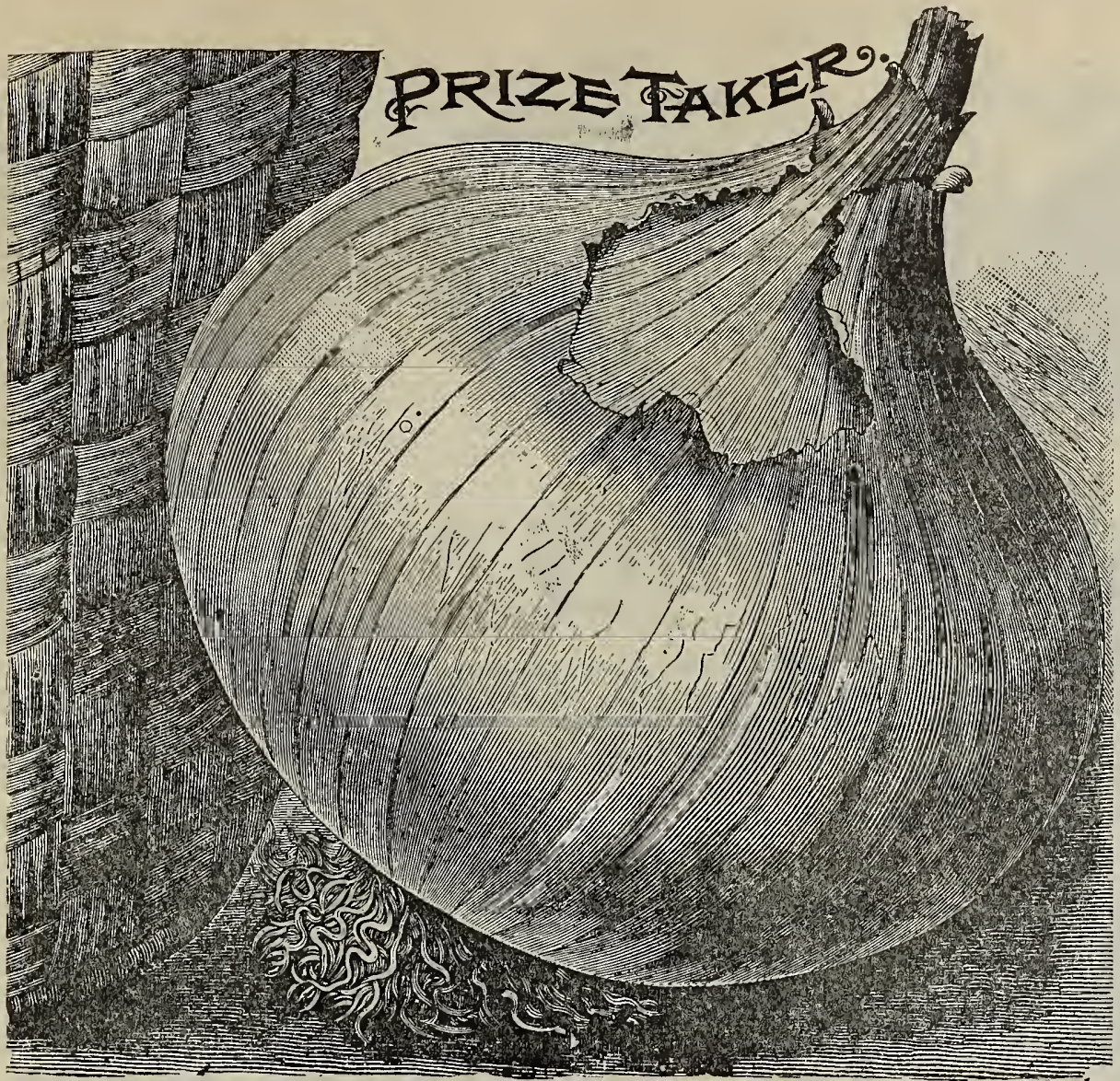

PERENNIAL

VARIETIES.

Egyptian, or Perennial Tree-In this we have an entirely distinct variety of Onions. Differs from all others in that when once set out, without the slightest protection, it will come up year after year as soon as the frost is out of the ground. Grows rapidly and is ready for market three to four weeks earlier than Onions grown from bottom sets. It never forms a very large bulb, is immensely productive, increasing both from the bottom and from sets produced on top of the stalks. Especially ad apted for growing green Onions for early spring. Should be planted in the fall. Sets, pint, 15c; qt., 25c, postpaid.

White MultiplierPlant in fall for early bunching purposes. Medium in size and produces bulbs from the sides. Sets, pint, 15c; qt., 25c, postpaid.

Potato Onion-Produces large bulbs and often as many as twenty small bulbs in clusters from a single bulb planted. Excellent quality and size for bunching green. A good keeper, very early. Should be planted in fall. Color pale red. Sets, quart, 30c, postpaid.

White Shallots-Bulbs large and a silvery white color, but never round; produce small bulbs on the sides. A very desirable variety for early bunching. Sets, quart, 30c, postpaid.

\section{ONION SETS.}

White Bottom Sets, quart, 20c, postpaid.

Yellow Bottom Sets, quart, 20c, postpaid.

Red Bottom Sets, quart, 20c, postpaid.

Top Onion Sets, quart, 20c, postpaid.

We make a specialty of Onion Sets. Write for special prices on bushel and larger lots.

REMEMBER-Prices on Onion Sets are quoted subject to change without notice. Should we be able to bill at less prices, will do so.

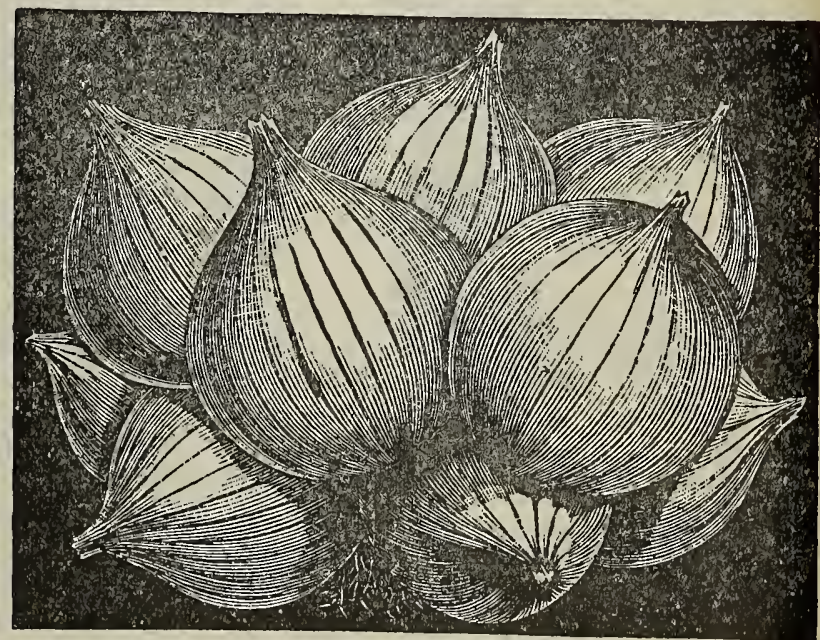

\section{PARSNIPS.}

One ounce will sow about two hundred feet of drill. Five pounds, one acre. The value of the Parsnip as a vegetable is well known, hut as a stock food, is not so well known. It is by far more nutritious than Carrots or Turnips, and in some sections is rapidly gaining favor as an economical farm product of great value, especially for dairy stock. Cultivation is similar to Carrots, and it is growing customary to leave Parsnips in the ground over winter, as frost improves the flavor.

Large Sugar, or Hollow Crown-Deriving its name from a slight depression on the top or crown of the root. Roots are comparatively short with a small top. Root grown mostly below the surface and has a clean, smooth skin. Pkt., 5c; oz.. 15c; 1 lb., 20c; lb., 55c.

Long White Smooth-A long white root, very smooth, tender and sweet. Very hardy and a good winter keeper. Will stand the winter without protection. Pkt., 5c; oz., 15c; $11 \mathrm{~b} ., 20 ; 1 \mathrm{~b} ., 55 \mathrm{c}$.

Half Long Short Round-Extra early; rather small; very valuable for bunching. Plat., 5c; oz., $10 \mathrm{c} ; \frac{1}{2} 1 \mathrm{~b} ., 20 \mathrm{c} ; 1 \mathrm{~b} ., 55 \mathrm{c}$. 


\section{PARSLEY.}

One ounce will sow rco feet of drill. Hardy and easily grown. Very fine for garnishing, as well as useful in flavoring soups etc. Soak seed for several hours and sow in rows, and, if to be carried late into the fall, set eight inches both ways. Will go through the winter with moderate protection.

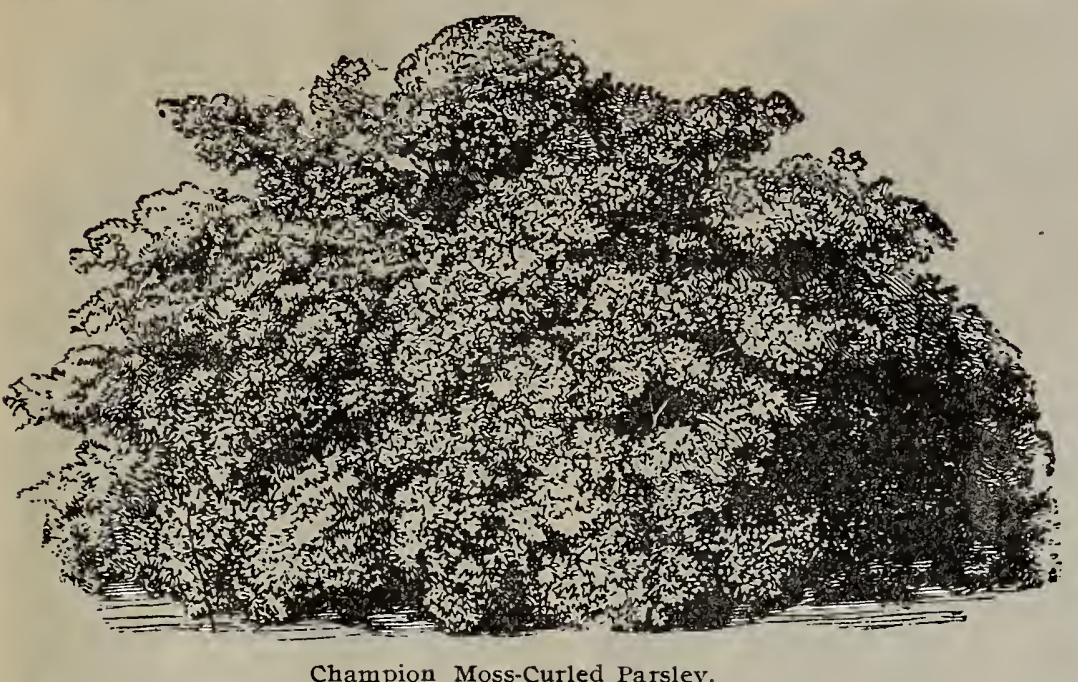

Double Curled-An excellent variety for garnishing meats. Pkt. $5 c$; oz., 10c; $\frac{1}{4} 1$ b., 20c; 1b., 65c.

Champion Moss CurledLeaves beautifully curled and mossy. Pkt., 5c; oz., 10c; $\frac{1}{4} 1$ b., 20c; 1b., 65c.

Turnip-Rooted, or German Parsley-A fleshy-rooted variety. Roots used for flavoring soups, etc. Pkt., 5c; oz; 10c; $\frac{1}{4} 1$ b., 20c; 1b., 65c.

Our Discounts are Liberal on Seeds in Packets. See Page 3 and Order Sheet.

Like produces //ke-Good Seed,Good Results.

\section{PLANTS.}

All sorts of Vegetable Plants in season, our own growth.

We will receive them fresh daily throughout the season, and will ship carefully packed at the following prices:

Early Cabbage Plants-For delivery in Apri1 and May, 30c per 100; $\$ 2.00$ per 1,000.

Late Cabbage Plants-Ready for shipment by July 1st, 25c per 100; $\$ 2.00$ per 1,000.

Cauliflower Plants-March and April, 25c per doz., $\$ 1.75$ per 100 .

Celery Plants-For shipment July 1st. Your own selection as to variety, 40c per 100; $\$ 3.00$ per 1,000.

Lettuce Plants-Ready from January to May, 30c per $100 ; \$ 2.50$ per 1,000 .

Egg Plants-Ready in May and June. Pot-grown, 60c per doz. Hot-bed plants, 25c per doz., \$1.75 per 100 .

Pepper Plants-Ready in May and June. Large Be11, Ruby King and Cayenne, 20c per doz.; \$1.25 per 100.

Tomato Plants - Good stocky plants (twice transplanted). Our specialty, ready in May and June. Will supply you throughout the season with all leading varieties, at 20c per doz; $\$ 1.00$ per $100 ; \$ 8.00$ per 1,000. Seed-bed plants, $\$ 4.00$ per 1,000 .

Sweet Potato Plants-All leading varieties during season, 25c per 100; $\$ 2.00$ per 1,000 .

In order to facilitate the filling of orders, we request that they be sent in early. Give us ample time to select, pack and ship your order properly. By doing so you will secure better plants, and they will reach you in better condition.

\section{Write for special prices on Plants in larger quantıties.}

\section{PEPPER.}

Pepper seed should be sown in hot-beds or cold-frame, and transplanted about the last of May. Can be sown in the open ground when the weather becomes settled. Well fertilized, warm, mellow soil is best adapted for the culture of Perpers. Frequent applications of liquid manure should be given to get the best results.

Ruby King-Grows four to six inches in length, three to four inches in diameter. Color a bright red; very mild in flavor, used largely for stuffed pickles; Pkt., 5c; oz., 20c; $\frac{1}{4} 1$ b., 65 .

Large Bell, or Bullnose-An old standard variety, used for chopped pickles. Pkt., 5c; oz., 20c; $\frac{1}{4} 1 \mathrm{~b} ., 65 \mathrm{c}$.

Procopps Giant-Fruit very large, about six inches in length; color a glossy scarlet, very fine. Pkt., 5c; oz., 25c; $\frac{1}{4} 1 \mathrm{~b} ., 75 \mathrm{c}$.

Golden Dawn-Very ornamental and productive. Sweet and mild in flavor. Pkt., $5 \mathrm{c}$; oz., $25 \mathrm{c} ; \frac{1}{4} 1 \mathrm{~b}$., $65 \mathrm{c}$.

Red Cluster-Small and grown in bunches on top of stalk; hot and pungent. Very popular variety. Pkt., 5c; oz., 25c.

Cayenne Long Red-Cone-shaped, red pods. Very hot and used largely for sauces and pickles. Pkt., 5c; oz., 25c.

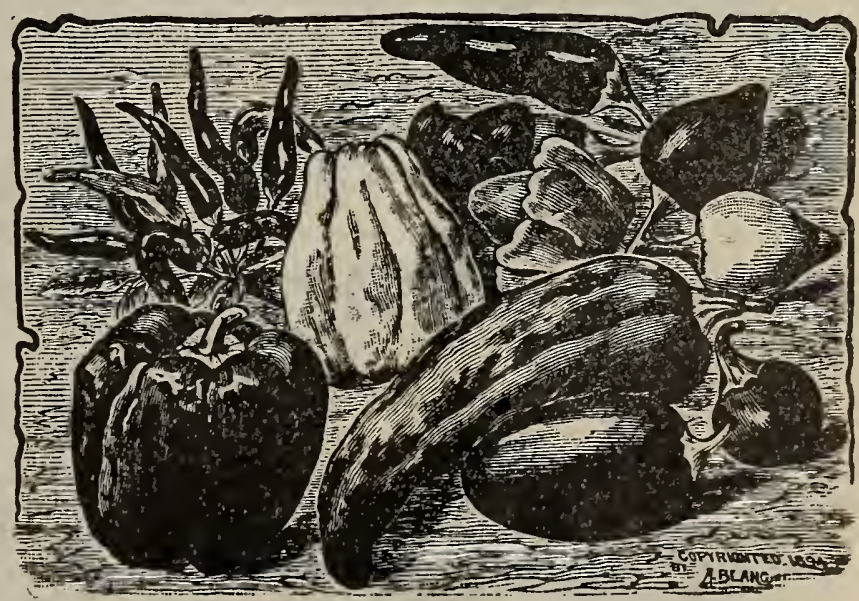

Small Cayenne-Red-hot. Used for bottled pepper sauce. Pkt., 5c; oz., 25c.

Celestial-A striking oddity. A very beautiful plant-variegated. Fruit, when fully matıred, a bright scarlet. Pkt., 5c; oz., 25c. 


\section{EXTRA EARLY DWARF PEAS.}

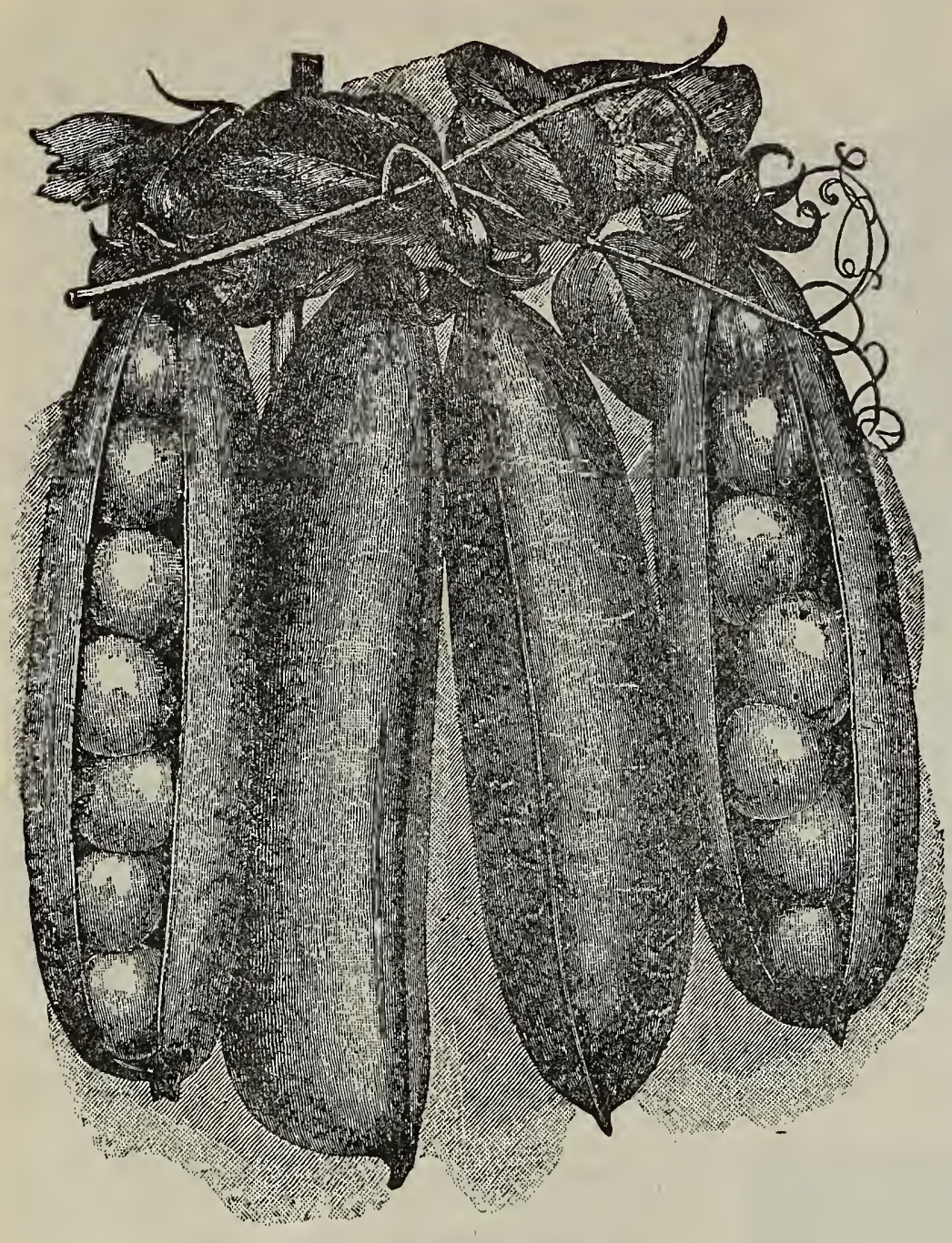

Nott's Excelsior. - Somewhat earlier than American Wonder, and larger podded. Vine very similar and the best dwarf wrinkled Pea. Ready for the table in forty-five days from planting. Pkt., 10c; pt., $15 \mathrm{c}$; qt., $25 \mathrm{c}$; peck, $\$ 1.60$.

Alaska-Very desirable for market gardeners. Peas are of a blue color when green; extra early and a good shipper. Ready for the table in six weeks from planting. Pkt., 10c; pint. 15c; qt., 25c; peck, $\$ 1.15$.

Little Gem-A green wrinkled Pea of excellent flavor. Very prolific and a great favorite with growers. Attains a height of $2 \frac{1}{2}$ feet. An early variety; matures in eight weeks. Pkt., 10c; pint, 15c; qt., $25 \mathrm{c}$; peck, $\$ 1.60$.

American Wonder-Vine six to eight inches high, and highly recommended for the family garden. Productive, unsurpassed in flavor. In maturity it is among the first earlies. A wrinkled variety. Pkt., $10 \mathrm{c}$; pint, $15 \mathrm{c}$; qt., $25 \mathrm{c}$; peck, $\$ 1.60$.

DWARF PEAS. SMOOTH-SEEDED VARIETIES.

Philadelphia Extra Early-A general favorite for market. Peas. smooth and of excellent quality. Height about two and a half feet. Pkt., 10c; pint, 15c; qt., 25c; peck, $\$ 1.10$; bu., $\$ 4.00$.

Plant's Extra Early-An extra early Pea of undoubted and wellknown value. Introduced and for some years past sold by Plant Seed Co. of St. Louis. Pkt., 10c; pint, 15 c; qt., 25 c; peck, $\$ 1.25$; bu., $\$ 4.00$.

First and Best-A favorite market sort, rather stocky, but vigorous. Prolific pods, well filled and of good size. Pkt., 10c; pint, 15c; qt., 25c; peck, $\$ 1.10$; bu., $\$ 3.75$.

Maud S.- One of the best of the extra early varieties. Peas are round, uniform and of even size. Vigorous grower; produces vines about thirty inches in height. Ripens very uniformly. Pkt., 10c; pint, $15 \mathrm{c}$; qt., $25 \mathrm{c}$; peck, $\$ 1.25$; bu., $\$ 4.00$.

Tom Thumb-An old standard sort and long known to the trade. Dwarf in habit, even in growth; so well known that it needs no further description. Pkt., 10c; pint, 15c; quart, 25c.

Prices on Peas include postage on Packets only; by mail, add $8 \mathrm{c}$ per pint, $15 \mathrm{c}$ per quart. Pecks and larger quantities by express or freight, at purchaser's expense.

FREE-WE GIVE YOU A PREMIUM WITH ALL MAIL ORDERS, NO MATTER HOW SMALL THE ORDER.

\section{SECOND EARLY SORTS.}

Horsford's Market Garden-An excellent second early variety. A green wrinkled Pea and undoubtedly the best ever introduced. Attains a height of about two feet. Extremely prolific, and of a very even growth. Pods medium in size and well filled with peas of very delicious flavor. Cannot be too highly recommended, especially to the market gardener. Pkt., 10c; pint, 15c; qt., 25c; peck, $\$ 1.15 ;$ bu., $\$ 4.00$.

Everbearing-A green.seeded, wrinkied, slightly flattened variety. for late planting. Very hardy, vigorous grower and an enormous cropper. and superior quality. Pkt., 10c; pint, $15 \mathrm{c}$; qt., 25c; peck, $\$ 1.15$; bu., $\$ 4.00$,

Height about two feet. Used Pods and peas of large size 


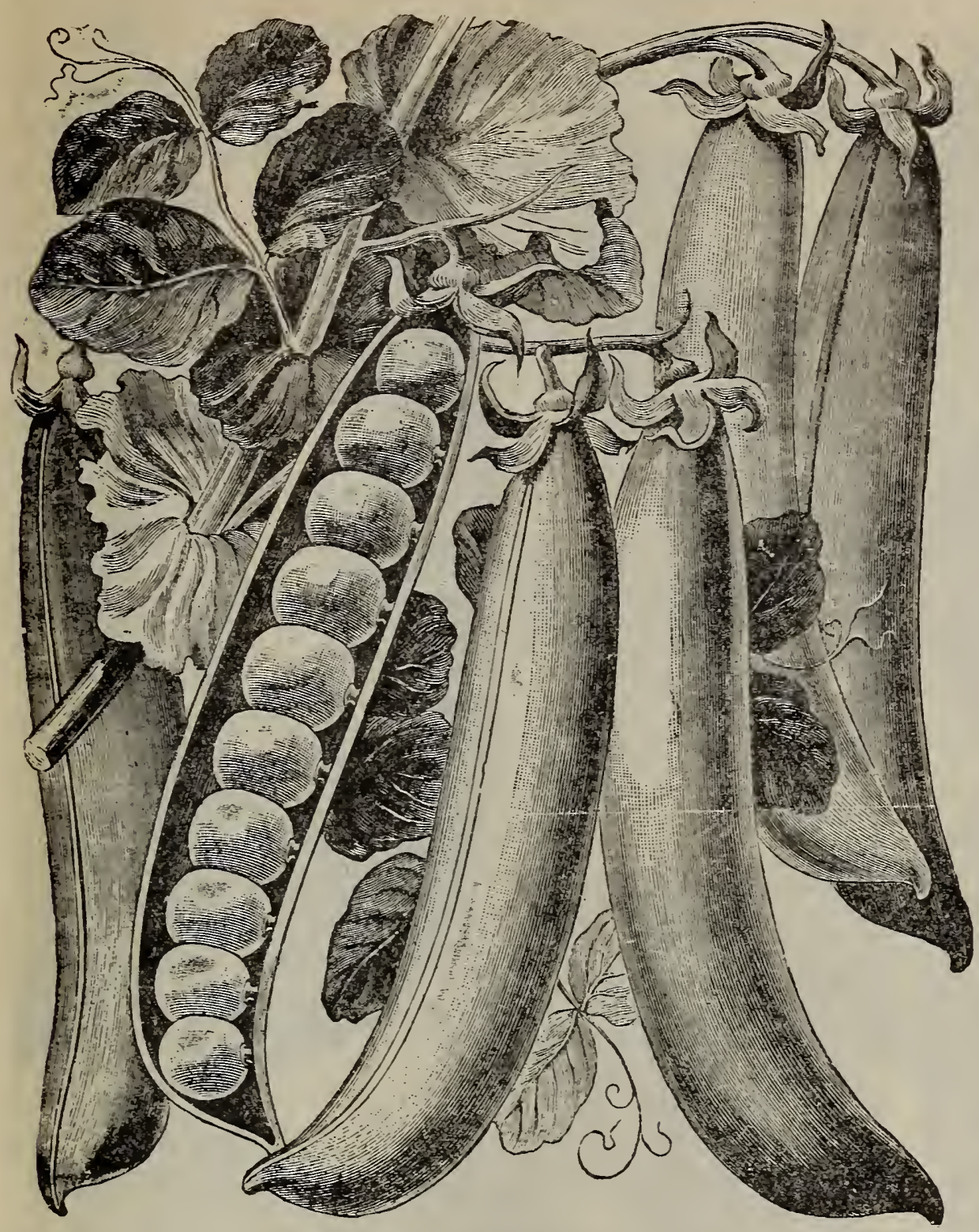

Bliss' AbundanceGrows about two feet high. Foliage large and full; pods from three to three ond a half inches long. Round and well filled. Usually containing from six to eight peas of an excellent quality. Pkt., 10c; pt. 20c; qt., 30c; peck, \$1.15 bu., $\$ 4.00$.

McLean's Advancer. -A second early green wrinkled variety of delicious flaror, attaining a height of about two and a half feet, and a great favorite with growers. Pkt., 10c: pt. 15c; qt., 30c; peck, \$1.15; bu., $\$ 4.00$

Improved Stratagren-The rery best of the 1arge-podded semidwarf English rarieties. The pods are of immense size and uniform$1 y$ filled with large dark green peas of the finest quality. Vines are medium, light green leared. Pkt., 10c; pint, $15 \mathrm{c}$; qt., 30c: peck, 51.25; bu.. $\$ 4.25$.

New Heroine.-A green wrinkled sort of delicious flaror, combining quality and quantity in a degree possessed by no other variety. Height two and a half feet. Prolific. Pkt., 10c; pt.. 15c: qt. 25c; peck, \$1.10: bu., $\$ 4.00$.

Horsford's Market Garden.

Shropsine Hero-A rery handsome wrinkled Pea, uniformly growing two and a half feet high. Very prolific, long, well-filled pods; a fine acquisition and well adapted for market gardeners. Plit., 10c; pint, 15c; qt., 30c: peck, $\$ 1.10$; bu., $\$ 4.00$.

Pride of the MarketA large-podded variety; generally attains height of two feet. Its superior appearance, productiveness and grand pods filled with 1arge, finely flarored peas, make it a favorite with the market gardeners. Pkt., 10c; pint, 15c; qt., 30c; peck, s1.40; bu., \$5.00.

We deliver free to con= sumer Seeds in Packets with liberal discounts. See order sheet and page 3.

\section{THE "RAPID-EASY" GARDEN WEEDER.}

A New Hand Implement, Which for Speed and Easy Work at Killing Weeds Eclipses Everything.

The blade is eight inches long, two inches wide, made of fine shore1 stee1, zig-zag in shape and double-edged to cut either when pushed or pulled through the soil. Edges are beveled like those of mowing machine knives, upturned ends of the blades are two inches high, also two-edged, bereled on inside. The hardwood handle is fire feet long.

It slips easily through the ground, either when pushed or pulled.

It can be run close to a row of plants without cutting them. Works easier than a hoe and much faster. It is light, strong, durable and cheap.

More Work Can be Done in One Hour With It Than With a Hoe in Three. BY EXPRESS, 75 cts. 


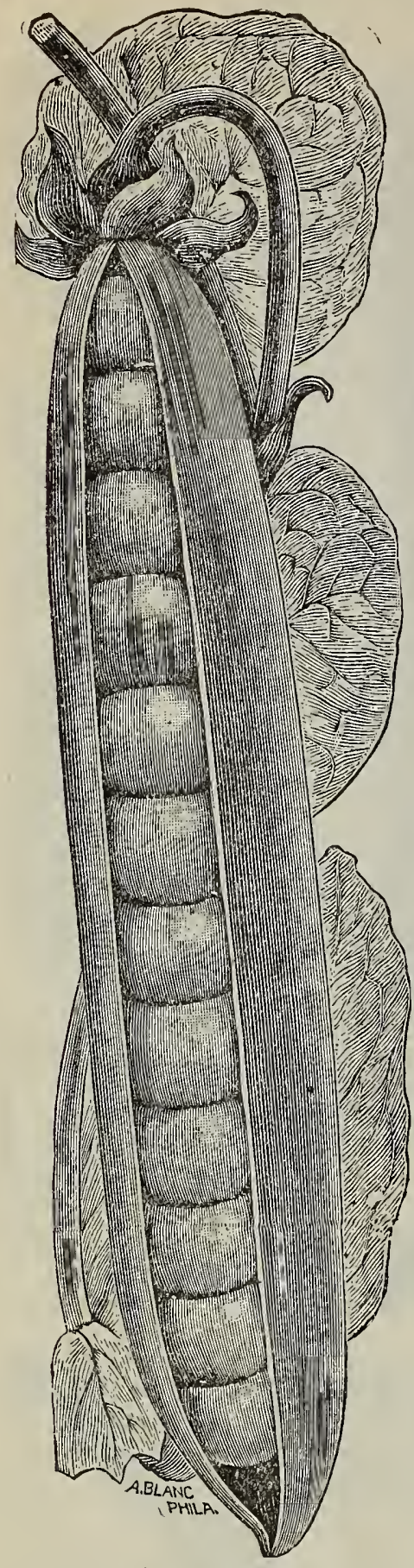

Bliss' Abundance.
Champion of EnglandOne of the richest and finest flavored Peas in cultivation. Very prolific, attains a height of four or five feet. Peas of a whitish-green color, and wrinkled. One of the best of its season for market and family use. Pkt., 10c; pint, 15c; qt., 25 c; peck, $\$ 1.10$; bu., $\$ 4.00$.

Telephone-A robust variety of English origination. Long pods containing from ten to twelve large and finely flavored peas. A long cropper and especially suited for the home garden. Height four to five feet. Pkt., 10c; pint, 15c; qt., $30 \mathrm{c}$; peck, $\$ 1.15$; bu., $\$ 4.00$.

White Marrowfat.-An old and well-known favorite of fine quality. Height about five feet. Pkt., 5c; pint, 15c; qt., 25c. Peck, 75c; bu., $\$ 2.75$.

Black-Eyed Marrowfat Height about four feet. Hardy and very productive; grown extensively for field and table use. Pkt., 5c; pint, 15c; qt., 25c. Peck, 75c; bu., $\$ 2.75$.

\section{Tall Sugar, Edible Pod-} Grows to a height of about five feet; bears a profusion of large, broad pods, which are so brittle that they can be used in much the same way as a green bean. Pkt., 10c; pint, $15 \mathrm{c} ;$ qt., 30c; peck, $\$ 2.00$.

Dwarf Sugal-In habit of growth somewhat similar to the American Wonder or Little Gem. Pods are beautifully crimped and of large size, considering the dwarf habit of the plant. Pkt., $10 \mathrm{c}$; pint, $15 \mathrm{c}$; qt., $30 \mathrm{c}$.

Prices on Peas include postage on Packets only, By mail add $8 \mathrm{c}$ per pint, 15c per quart. Pecks and larger quantities by express or freight at purchasers' expense.

Do not wait until the busy season to order. Place your order early and avoid delay and greatly oblige us.

\section{RHUBARB.}

A hardy perennial plant, cultivated for its acid leaf stalks, which are used for pies, sauces, cavning, etc. Sow the seed in A pril drills one foot apart, one inch deep; thin to a foot apart. The following fall or spring transplant to trenches six inches deep, three feet apart, and 3 to 5 inches apart in the trench. Propagation may be made by division of the roots in the fall, placing the sets at the same distance apart as recommended for seedlings. Cultivate thoroughly, and cover with manure each fall. Care should be used in removing the stalks by pulling off close to the roots; 11ot desirable to cut, as the sap flows more freely from a square cut.

Victoria-A large and tender variety, skin thick and red stained. Pkt., 5c; oz., 15c; $\frac{1}{4} 1 \mathrm{~b} ., 50 \mathrm{c}$.

Linnacus-The earliest sort grown; very popular for the market and family garden. Plkt., 5c; oz., 15c; $\frac{1}{4} 1 \mathrm{~b} ., 50 \mathrm{c}$.

Roots, not prepaid, each, 10c; per doz., \$1.00.

\section{HORSE RADISH.}

This plant, seldom producing seed, is propagated from sets cut from old roots. Plant in rows about two feet by eighteen inches. It will succeed best on highly fertilized land, and each year should be planted afresh.

Roots, per dozen, 20c; per 100, 75c, postpaid, Special prices on large quantities, 


\section{RADISH.}

One ounce of seed will sow soo feet of drill. Radishes are chiefly cultivated for their roots, although many times the young seed leaves are used as a salad, and the green seed pods often for pickles. Should be sown early in the spring, and for the best re seed leaves are used as a sal
sults on a rich, sandy soil.

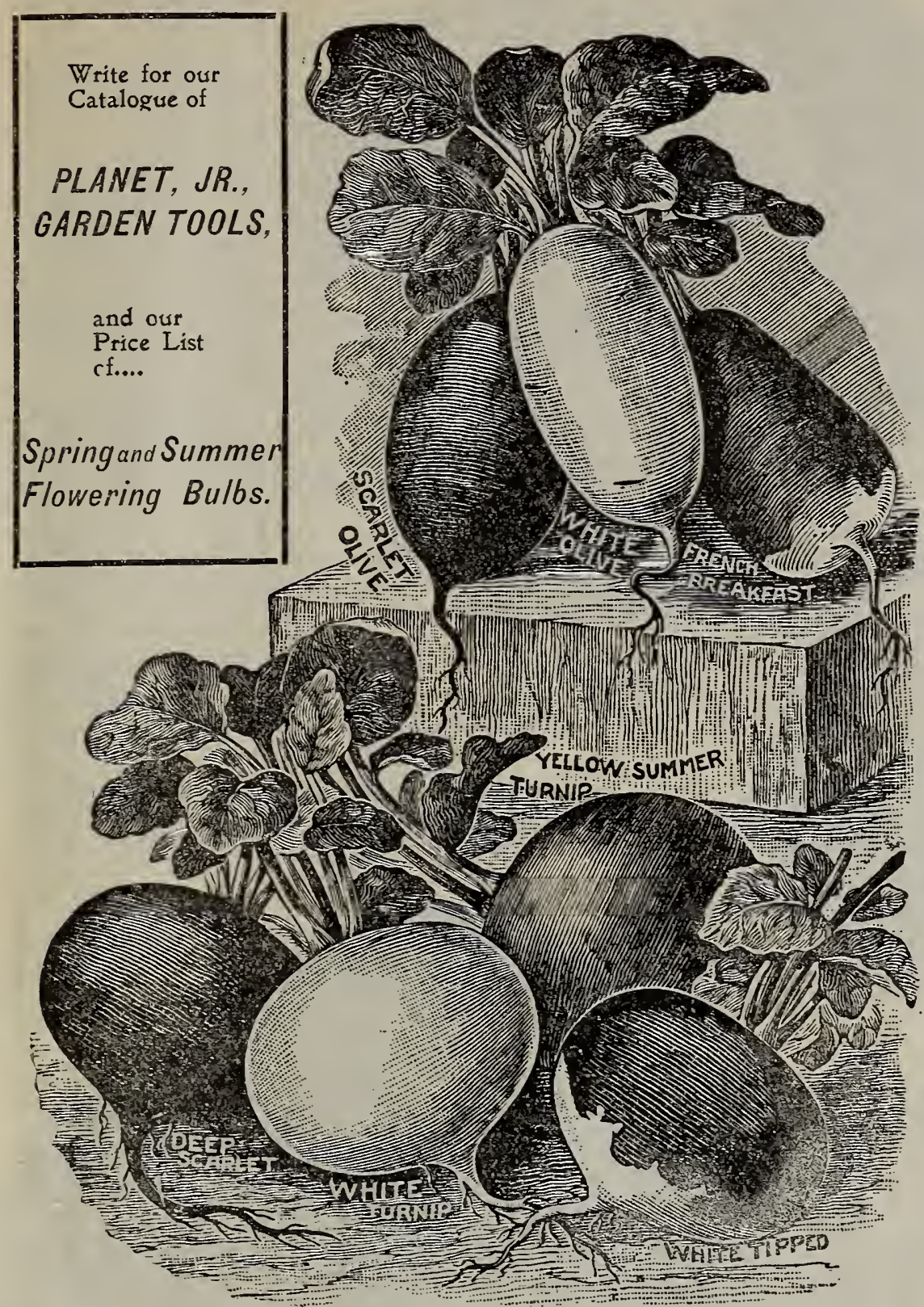

Extra Eariy Scarlet Turniy - Color a deep scarlet and for many years a rery popular variety. Pkt., 5c; oz., 10c; 1-4 1b. $25 \mathrm{c} ; 1 \mathrm{~b} ., 65 \mathrm{c}$; postpaid.

Scarlet Turnip, WhiteTipped-Very similar to Early Scarlet Turnip, with the exception of the white tip. Used largely for forcing. This variety is too well known by all market gardeners to need further description. Pkt., 5c; oz., 10c; 1/4 1b., 25c; 1b., 65c; postpaid.

Philadelphia White BoxPerfect turnip shape; a long cropper, remaining solid, sweet and juicy long after having reached maturity. Grows rapid$1 y$ and very desirable for forcing purposes. Pkt., 5c; oz., 10c I/t 1b., 25c; 1b., 65c; postpaid.

Carmine Turuip-A remarkably early variety, color a fine, rich carmine; very mild and tender. Pkt., 5c; oz., 10c; 1/4 1b., $25 \mathrm{c} ; 1 \mathrm{~b} ., 65 \mathrm{c}$; postpaid.

Market Gardeners' Long Scarlet - A variety more largely used, perhaps, than any other for outdoor planting. Growing six to eight inches in length, and possessing all the qualities of a fine radish.

Lono White Viemua, or Lady Finger-One of the finest and most popular of the long radishes; growing six to eight inches in length: beautiful in shape, skin and flesh pure white.

Wood's Early Frame-Very similar to Long Scarlet, with the exception of being white-tipped, shorter, and about ten days earlier. Used largely for forcing.

White Strasburg-A leading variety for the home or market garden; half-long in shape, skin and flesh pure white; a fine sort for late planting, growing to a good size, and withstands the heat of the late summer, remaining firm and brittle longer than most varieties.

St. Louis White Summer-Very similar to Strasburg, but somewhat longer.

Improved Chartier-Color at the top a bright crimson, running into pink about the middle; from thence down to pure white. A quick grower and very popular.

Giant White Stuttgart-Very large in size; flesh and skin white, firm and rery brittle, and used largely for late planting.

Early White Tumip-Similar to Philadelphia White Box.

French Breakfast-An old and well-known sort of great value.

Olive-Shaped White-A well-known sort.

\section{OUR RADISH SEED COMES DIRECT FROM THE BEST FRENCH AND AMERICAN GROWERS.}

Try our Mixed Lawn Grass. Per 1b. in 1 1b. cartons, 25c; per bushel in hulk, $\$ 350$.

We deliver free, direct to consumer, Vegetable Seeds, Flower Seeds and Bulbs, except where noted. 


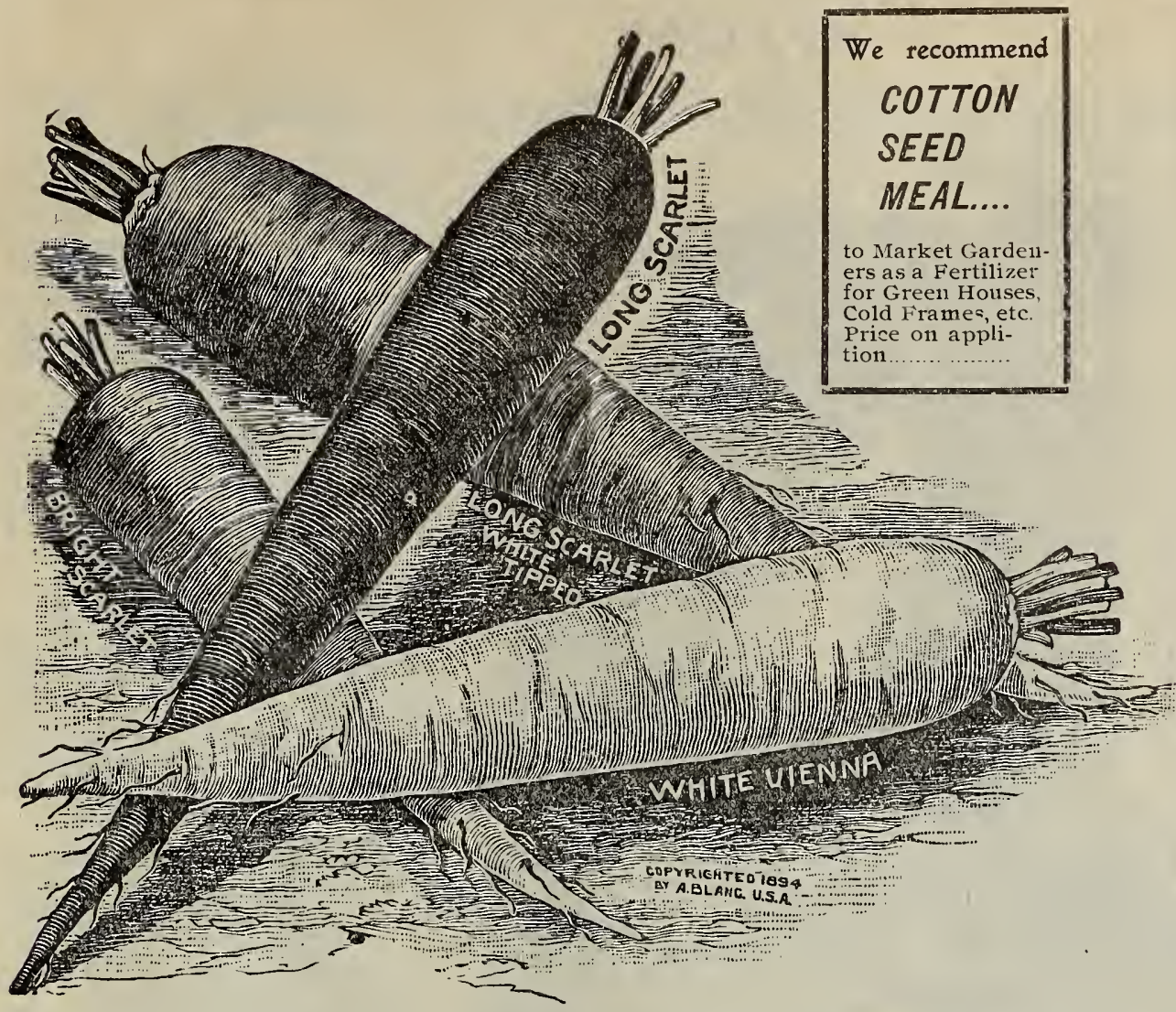

Olive-shaped Scarlet.-A wellknown variety.

Gray Summer Turnip.-For 1ate planting.

Yellow Summer Turnip.-For. late planting.

\section{WINTER}

VARIETIISS.

Round Black Spanish. - G1obe shaped, black skinned, white flesh and very hardy; highly flavored.

Lo 11 g B l ack Span is h. - Very hardy and a very large sort. Flesh solid and a good keeper. An excellent variety for winter use. Roots oblong.

Chinese RoseFlesh white, firm and of a very superior quality; skin of a bright rose color.

California Mammoth White-A very fine winter sort of immense size and an excellent keeper.

Radish, postpaid, Packet, 5c; oz., 10c; 1-4 Ib., 25c; lb., 65c. Any seven varieties. 1 packet each, $25 \mathrm{c}$.

\section{SQUASH.}

The Squash is one of the most nutritious and valuable of our garden vegetables. Summer varieties come to the table early in the season, while the winter sorts may be had from early fall until the summer varieties are again ready for the table. Should not be planted until settled warm weather, as the plants are very sensitive. Cultivate similar to cucumbers and Melons.

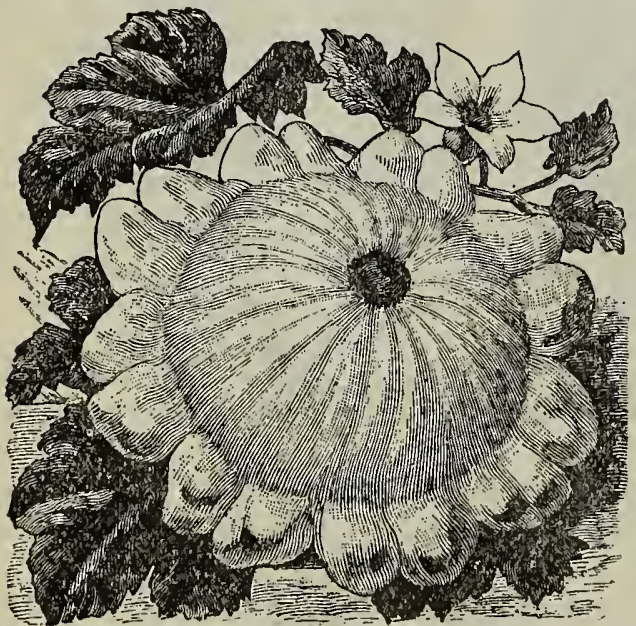

White Bush, or Pattypan-A pure white scalloped variety, flat, very early, and a great favorite. Plkt., 5c; oz., 10c; $1 / 4$ 1b., 25c; 1b., 60c.
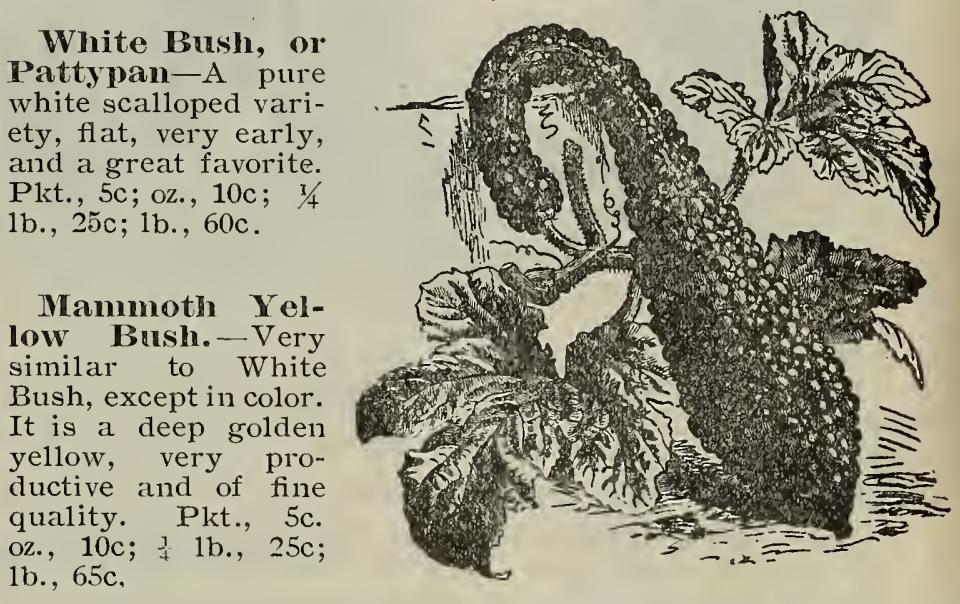

White Bush

Giant Snmmer Crookneck.

Giant Summer Crookneck-Much larger than the common variety and a great seller. Very early; has a rough, warty surface, a deep orange yellow color. Pkt., 5c; oz., 10c; $\frac{1}{4} 1 \mathrm{~b} ., 20 \mathrm{c} ; 1 \mathrm{~b} ., 60 \mathrm{c}$.

Fordlook-Outside color a bright yellow. Flesh a shade lighter; a strong, rapid grower, good keeper, sweet and delicious. Pkt., 5c; oz, $10 \mathrm{c} ; \frac{1}{4} 1 \mathrm{~b} ., 25 \mathrm{c} ; 1 \mathrm{~b} ., 65 \mathrm{c}$.

Essex Hybrid-Medium late, a good variety for second-crop ground. Flesh orange yellow, solid and

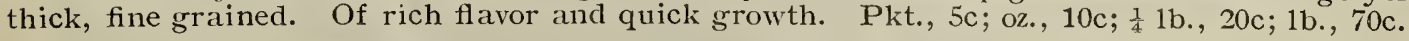

Try our Mixed Lawn Grass for a good lawn. Put up in one pound cartons; per 1b., $25 \mathrm{c}$; per bushel in bulk, $\$ 3.50$. 


\section{PUMPKIN.}

One ounce plants fifteen to twenty hills, according to size of seeds. It is usually grown with Corn or Potatoes; however, a ve profitable crop grown by itself. Plant in May, hills six to eight feet a part.

King of the Mammoth--A mammoth variety, often attaining a weight of 200 pounds. Flesh bright yellow, skin salmon color, very valuable for show Pumpkin. Seed selected trom 1arge Pumpkins and will give good results. Pkt., 5c; oz., 10c; 1b., 35c; 1b., $\$ 1.00$.

Cushaw WhiteSimilar to striped, except in color, being pure white. Pkt., $5 \mathrm{c}$ oz., 10c; 孝 1b., 20c 1b., 65c.

Mammoth rours -Grows to immense size, often weighing over 100 pounds. Plkt, 5c; oz., 10c; $\frac{1}{4} 1 \mathrm{~b} ., 30 \mathrm{c}$; 1b., 80c.

Jonathan--Large bottle-shaped variety with crooked neck, very attractive in appearance, used large$1 y$ for display at fairs, etc. Flesh very fine and sweet. Extra valuable for pies.

Pkt., 5c; oz., 10c; $\frac{1}{4} 1 \mathrm{~b} ., 25 \mathrm{c} ; 1 \mathrm{~b} ., 75 \mathrm{c}$.

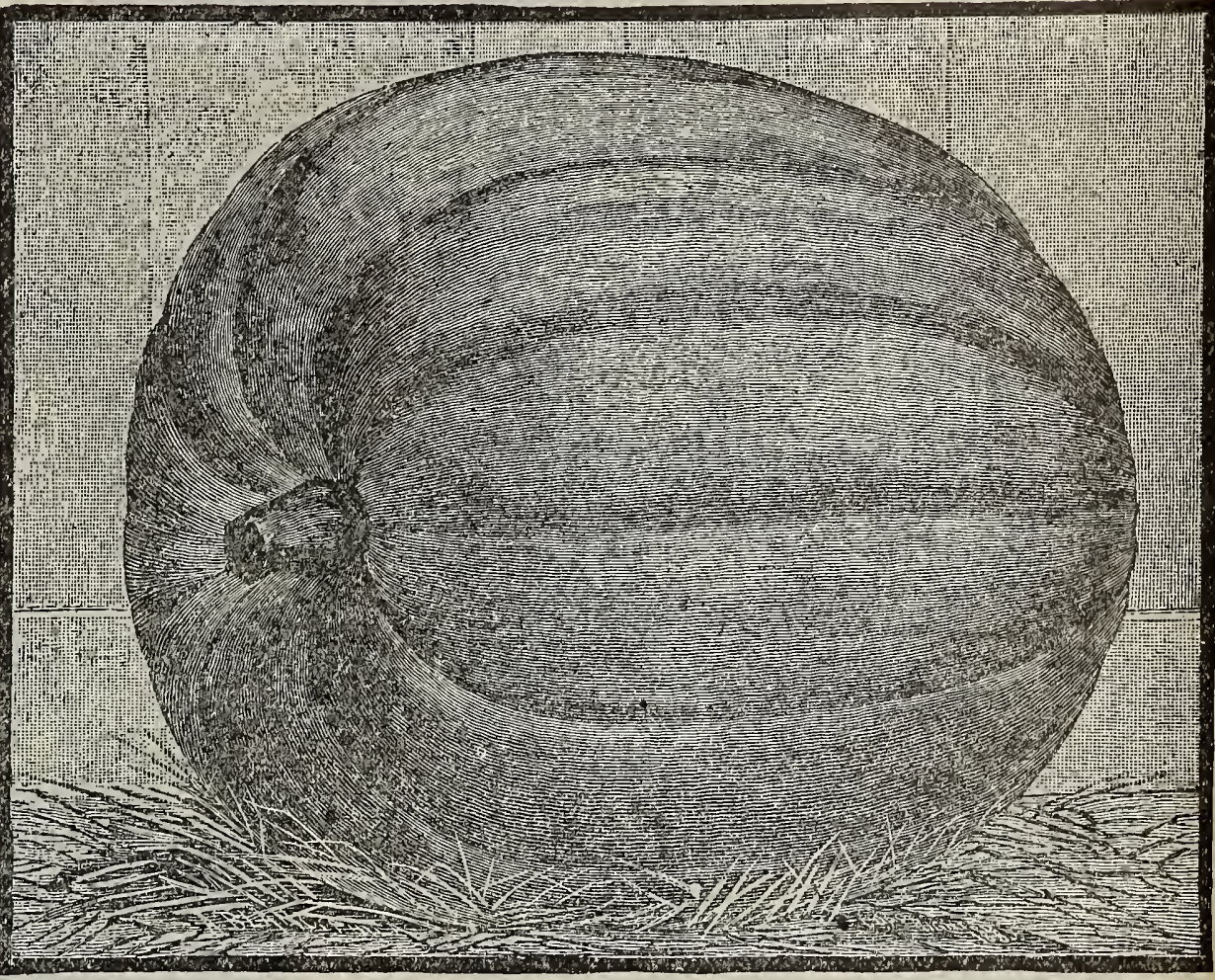

Cushaw Striped-A wel1-known variety. Pkt., 5c; oz., 10c; $\frac{1}{4} 1 \mathrm{~b} ., 20 \mathrm{c} ; 1 \mathrm{~b} ., 65 \mathrm{c}$

Connecticut-A very prolific variety, especially valuable for stock feeding.

To Stockmen-Write for special prices on field Pumpkin in quantities.

\section{POTATOES.}

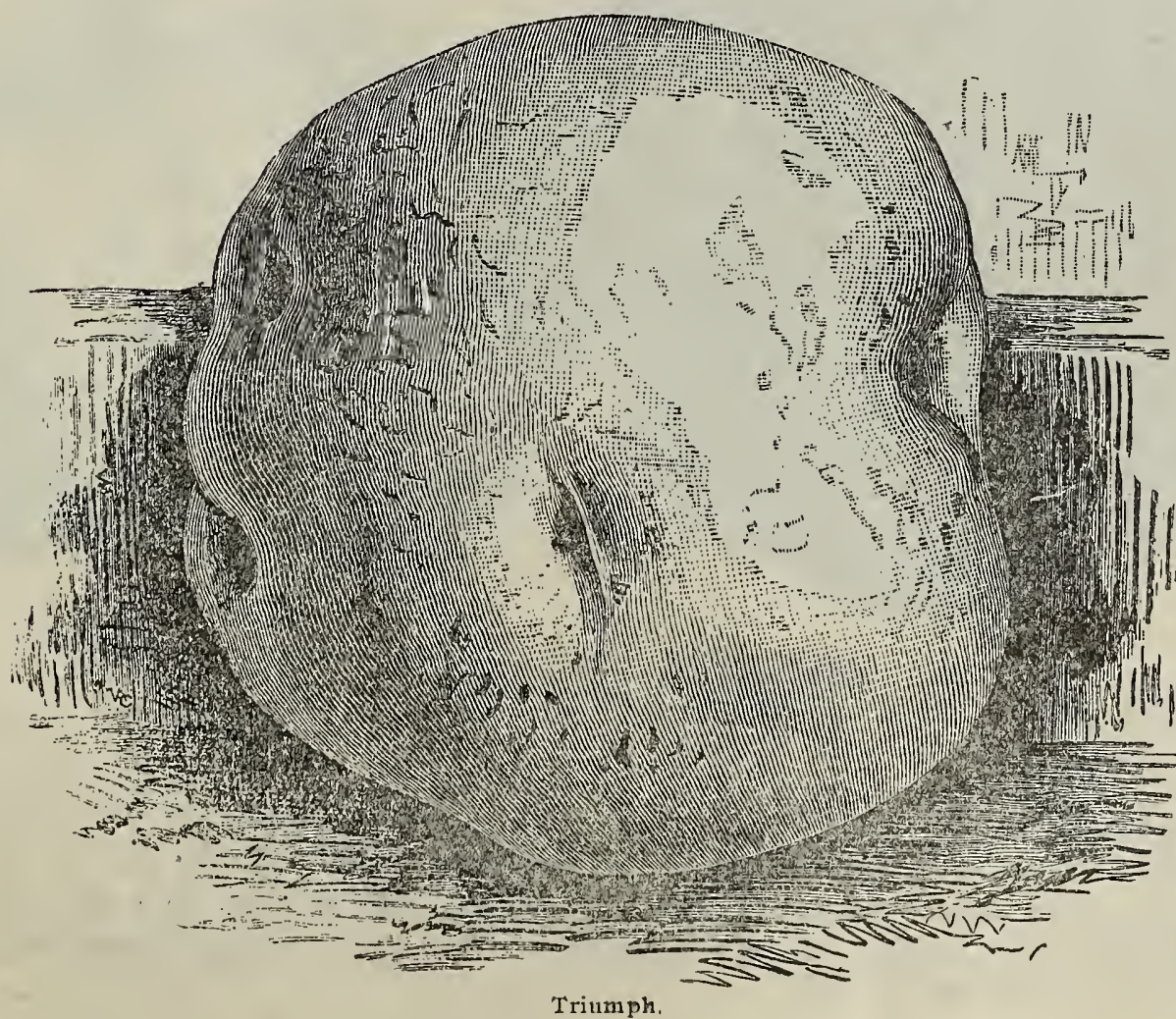

It has been our aim handle strictly Minnesot stock, and in comparin prices with competitio you will please note th we quote on this basis.

NOTE.-Prices subject to fluctuatio without notice. Cas with order.

We are in positic to supply many var eties not included this list.

Triumph-Beyond qu tion the very best ea Potato for this section; tremely popular in South; especially valua for early market Peck, 45c; $1 / 2$ bu., 80c; $\$ 1.50$.

Merchants in want straight stock, either in lots or local shipments, w us for prices. We guar tee no substitution. If do not have in stock $v$ eties to fill your order do not ship. 
Carly Ohio-Too old and well known to need any description. Our stock is strictly Minnesota grown. Peck, 35c; $1 / 2$ bu., 65c; bu., $\$ 1.25$.

Try our Mixed Lawn Grass for a good lawn. Put up in one pound cartons; per pound 25 cts. ; per bushel in bulk, $\$ 3.50$.

Like produces like-Good Seed, Good Results.

IF WE PLEASE YOU TELL OTHERS; IF NOT. $T E L L$ US.

Our Discounts are Liberal on Seeds in Packets. See Page 3 and Order Sheet.

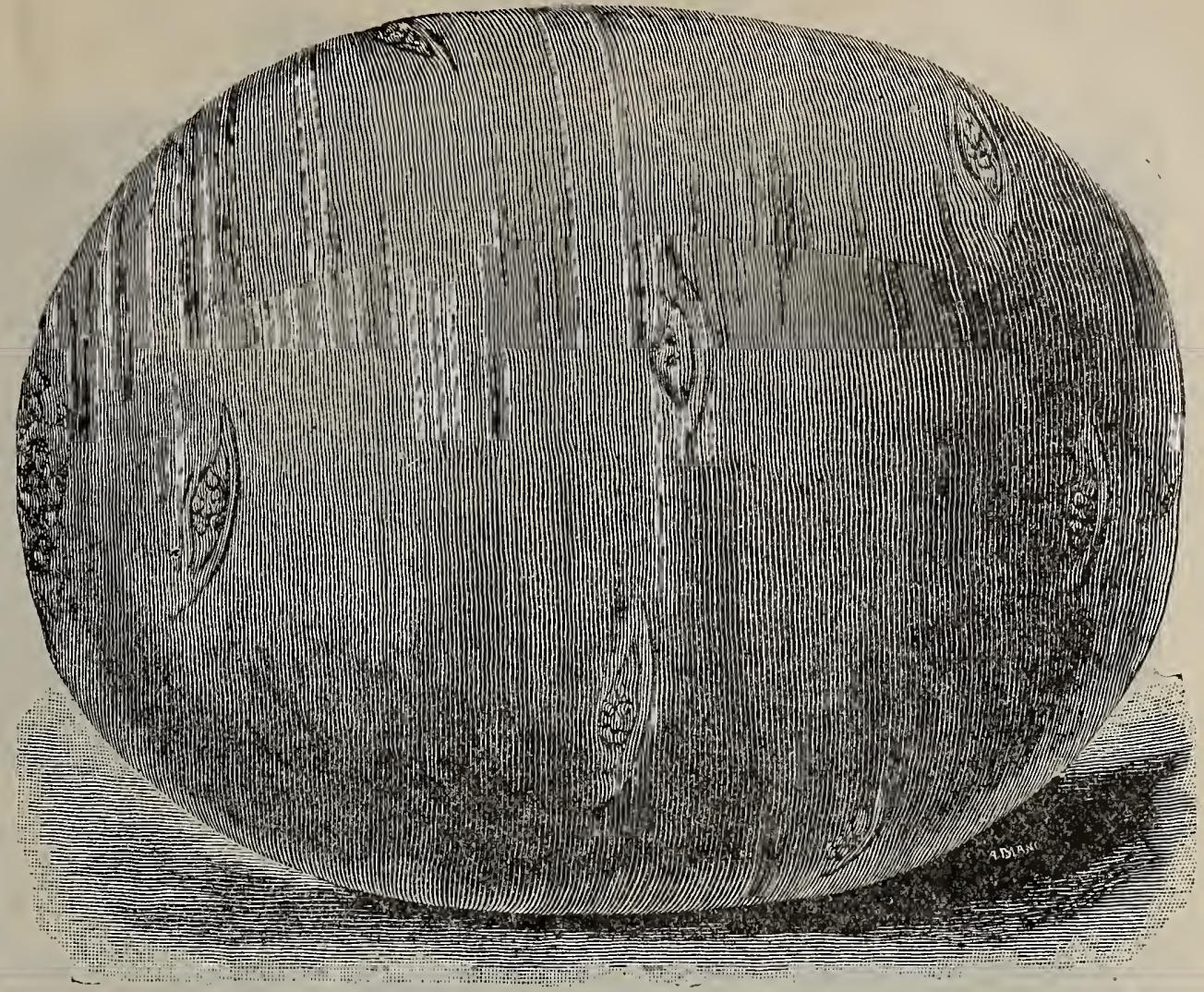

Early Ohio.

Early Rose.-An old sort and very popular. Peck, 35c; 1/2 bu., 65c; bu., $\$ 1.25$.

Burbank's. - Standard late Potato, one of the best. Peck, 35c; 1/2 bu., 60c; bu. $\$ 1.15$.

Beauty of HebronA favorite for family use; a good general cropper. Peck, 35c; 1/2 bu., 60c; bu. $\$ 1.15$,

Peerless - A rather late sort, large size and very productive. Peck, 35c; $1 / 2$ bu., 60c; bu., \$1.15.

We will fill a barrel of 165 pounds of any collection of the above varieties for $\$ 3.25$, subject to being unsold on recerpt of order.

Early Rose.

\section{SWEET POTATOES.}

Sweet Potatoes succeed Best in a light, sandy soil; stable manure is the best fertilizer. To obtain the sprouts, the entire
potato is planted in beds about two inches deep. One bushel of pot is planted in beds about 7,000 , lants. Protect the beds holvith old hay or trash until the sprouts appear. The sprouts in are transplanted to the field, and placed in rows four feet apart, and two feet in the row. Cultivation continues as needed antil stopped by the rumning vines. Crop should be harvested et or vines removed before frost

30: We handle both tubers and plants of the following varieties:

\section{Yellow Nansemond,}

Red Nansemond,

White Brazilian, Vineless or Bunch Yam, Yellow Jersey, Red Jersey,

Southern Queen, Yellow Yam, Early Golden.

We are careful to keep all varieties true to name. Prices on application cand shipment made the day the order is received.

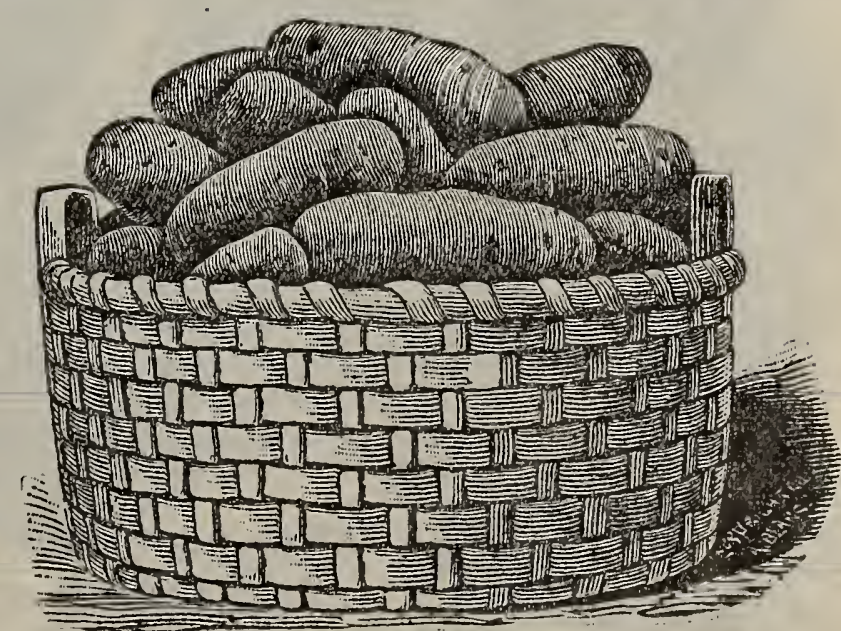

Minnesota Burbank 


\section{TOMATOES.}

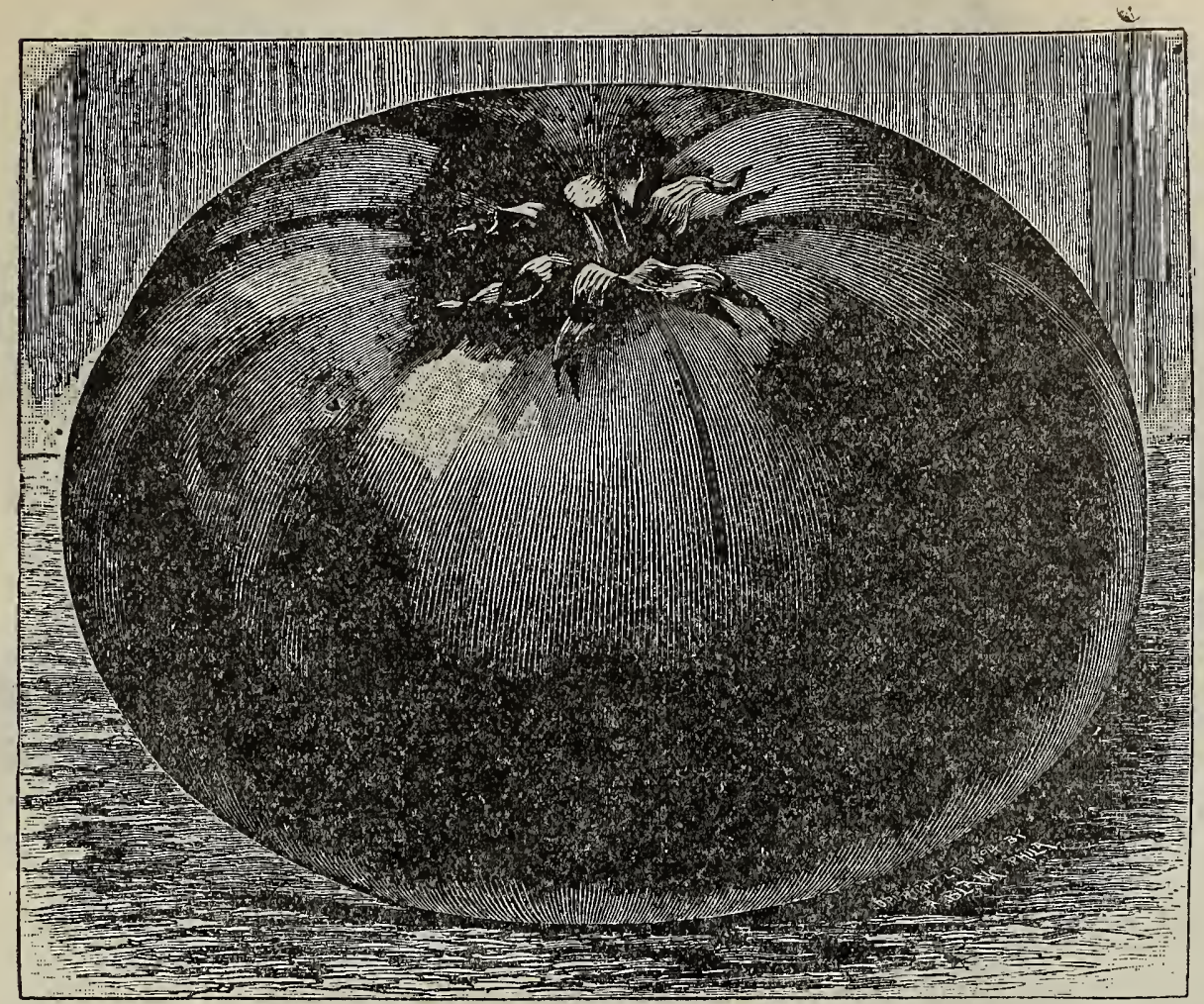

Dwarf Champiou.
Dwarf Champion or Tree Tomato-So long favored among the market gardeners and truckers and for the home garden.

Since its introduction, many varieties have been brought in competition with Dwarf Champion, but no better results. have been obtained. While not of remarkable size, it combines solidity and quality with earliness and smoothness. In fact, still remains the best early variety. To. those who contemplate growing plants, we would say, plant Dwarf: Champion. Pkt., 5c; oz., $20 \mathrm{c} ; \frac{1}{4} 1 \mathrm{~b}$., $55 \mathrm{c} ; 1 \mathrm{~b}$., $\$ 2.00$, postpaid.

Livingston's Beauty-This variety is one of the best ever produced by Mr. Livingrston. It has stood the test of time and still remains a favorite among growers. Of a purplish pink color, thick flesh and regular form. Pkt., $5 \mathrm{c}$; oz., $20 \mathrm{c} ; \frac{1}{4} 1 \mathrm{~b} ., 55 \mathrm{c} ; 1 \mathrm{~b} ., \$ 2$.

Dwarf Aristocrat - A red variety, similar in many respects to the Dwarf Champion; in size, solidity, productiveness and flavor is up to the best standard; used largely for glass culture, since its introduction. Its dwarf habit and upright growth permit close planting, making it a good vartety for outside culture. Pkt., 5c; oz., 25c; $\frac{1}{4} 1 \mathrm{~b} ., 70 \mathrm{c} ; 1 \mathrm{~b} . \$ 2.50$, postpaid.

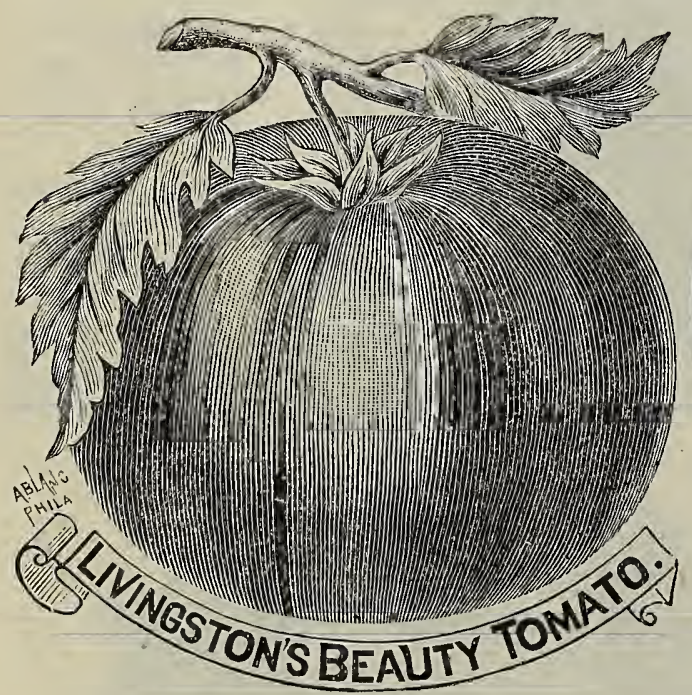

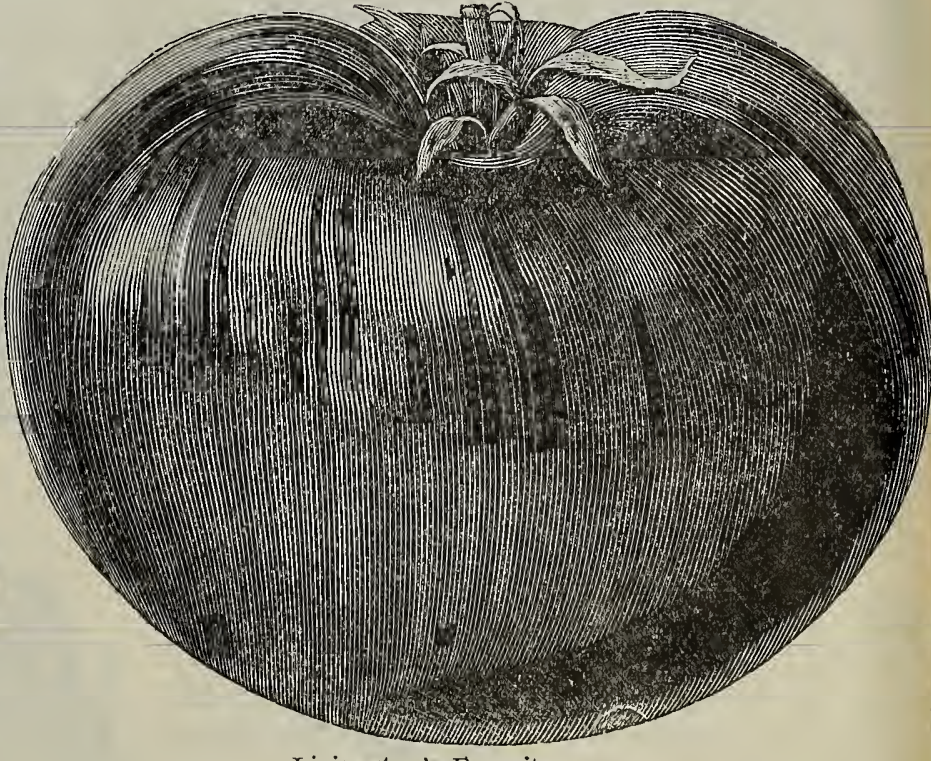

T,ivingston's Favorite.

Atlantic Prize - One of our main crop varieties, especially for earliness. Bears fruit in clusters, isnd of good size, smooth and round. A fine scarlet in color. Pkt., 5c; oz., 25c; $\frac{1}{4} 1 \mathrm{lb} ., 65 ; 1 \mathrm{~b} ., \$ 2.00$.

Buckeye State-A new sort introduced by Livingston; somewhat larger than Beauty, of deep color $r_{\text {pod }}$ is smooth and excellent quality. Pkt., 5c; oz., 20c; $\frac{1}{4} 1 \mathrm{~b} ., 65 \mathrm{c} ; 1 \mathrm{~b} ., \$ 2.25$.

\section{ARMOUR'S FOOD FOR FLOWERS.}

For potted plants, a top dressing for flower beds, to preserve cut flowers, etc. Put ur culliva in handsomely lithographed packages, with full printed directions for use. 1-2 1b. packlis ages, 15 cts.; 1 lb., packages, 25 cts, not postpaid, 


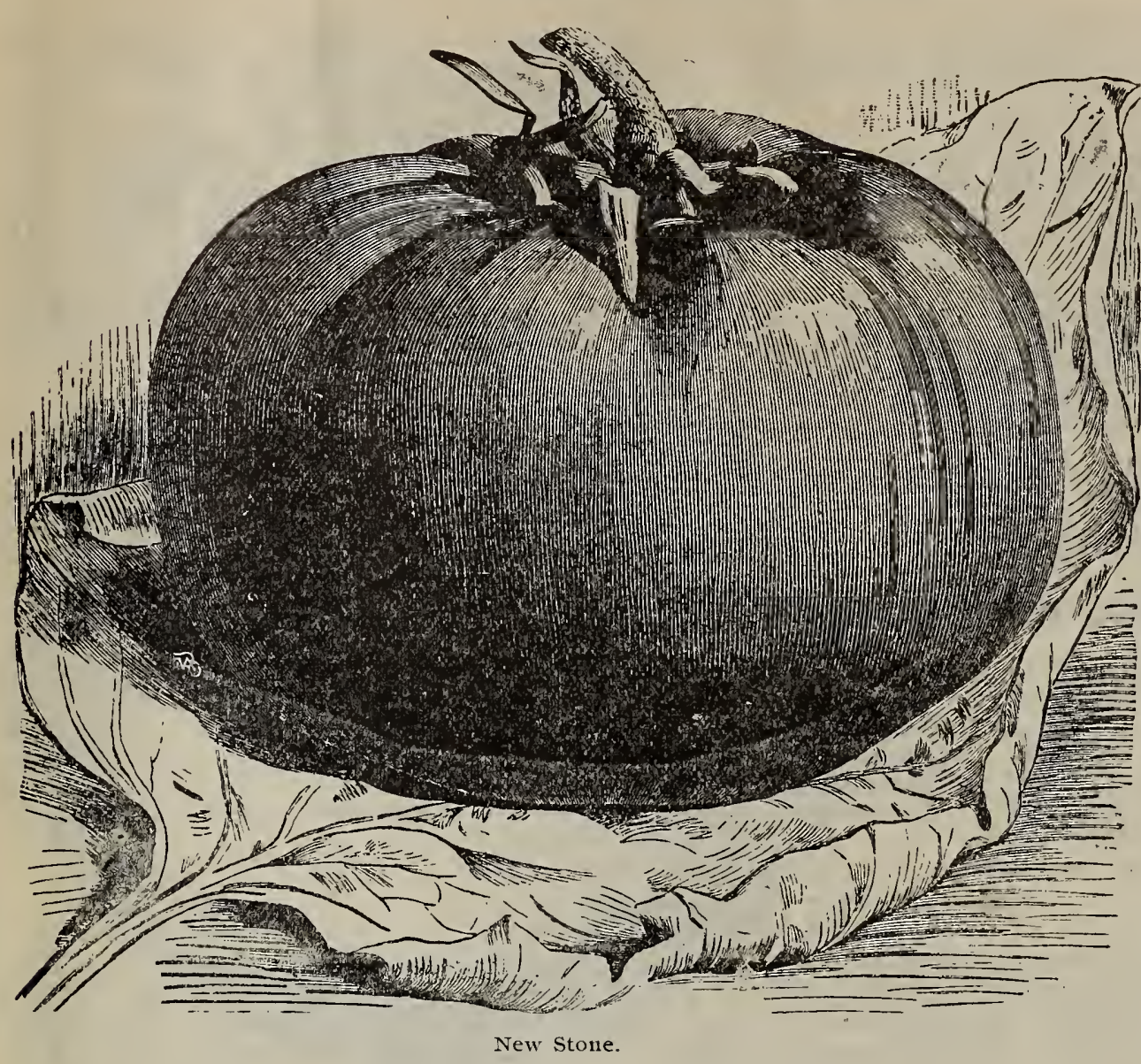

A c in e.-An oldtime popular variety, having at all times given entire satisfaction. Round, smooth purple. Our seed of good selection. Pkt., $5 \mathrm{c} ;$ oz., $20 \mathrm{c} ; \frac{1}{4} 1 \mathrm{~b} ., 50 \mathrm{c}$; 1b., $\$ 2.00$.

New Stone-For the past four years we have made a specialty of our New Stone Tomato to the canning trade with remarkable success. Our strain this season is of the same type, produced by the same grower, and we can assure our friends among the loca1 canners of the same service.

We feel assured of the patronage of those who have used our New Stone, and would ask of those who have been buying elsewhere to give us a chance to make you prices. It has been our custom through the past seasonto supply affidavit of germination to canners. Pkt., 5c;oz., 20c; $\frac{11}{4} 1 \mathrm{~b}$., $50 \mathrm{c} ; 1 \mathrm{~b} ., \$ 1.50$. Special price to canners.

Imperial-Of recent introduction; very early and one of the smoothest and most productive sorts. Fruit is large, a good keeper. Produces well throughout the season. Pkt., 5c; oz., 20c; $\frac{1}{4} 1 \mathrm{~b} ., 60 \mathrm{c} ; 1 \mathrm{~b} ., \$ 2.25$.

Ponderosa-Beyond question the largest sort in cultivation. Fruit ripens second early, grows somewhat scattering on the vine, when ripe is apt to remain green on the stem end and seems to ripen on the inside first. On this account should be picked when about three-fourths ripe. Especially adapted for home use. Its enormous size in weight makes it undesirable for market use. Pkt., 5c; oz., 25c; $\frac{1}{4} 1 \mathrm{~b}$, $75 \mathrm{c}$; 1b., $\$ 2.75$, postpaid.

Livingston's New Magnus-A variety ontroduced during the past season, and might be termed a novelty. It combines all the good qualities of the Beauty and the Acme. After a thorough trial this season it has proven to be the handsomest in appearance; flesh is firm, ripens evenly, and seems especially free from cracks. Being of luxuriant growth, we recommend that it be staked in the open field. Pkt., 10c; oz.. 30c; postpaid.

\section{Perfection-Solid} flesh, always smooth and of blood-red color. This is a general favorite, equally desirable for the home garden, for shipping and for canning. We have an exceptionally choice stock of this sort. Pkt., 5c; Oz., $20 \mathrm{c}$; $\frac{1}{4} 1 \mathrm{~b} ., 50 \mathrm{c} ; 1 \mathrm{~b}$, $\$ 1.75$.

Favorite-A smooth variety, very dark red in coior, which does not crack. Very solid meat having few seeds. Large and uuiferm in size, ripens evenly to the stem, is an especially coll grood variety for growers who sell by weight, it being conceded that it is the heaviest variety now in cultivation. Pkt., $5 \mathrm{c}$; put w oz., 20c; $\frac{1}{4} 1 \mathrm{~b} ., 50 c ; 1 \mathrm{~b}$,

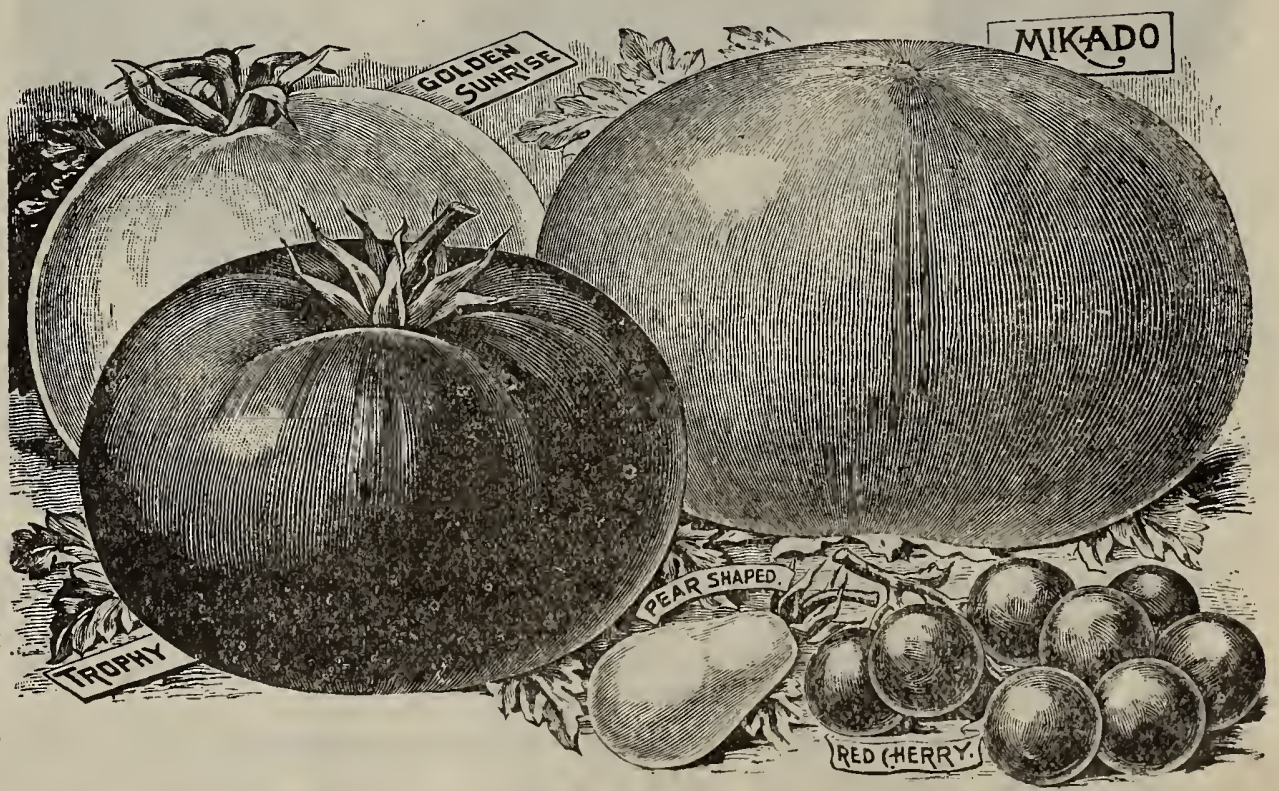
$\$ 1.50$. 
Well-known Standard Varieties. Per pkt., 5c; per oz., 20c; except where noted.

Golden Queen-Rich deep yellow

Matchless-Very large, smooth, a good keeper

Liberty Bell-Extra early; 1arge size, bright red, fine quality

Paragon-Red, productive, a standard for market

Livingston's Royal Red-Skin and flesh deep red; fine for main crop

Trophy-An old favorite; very solid, large and late

IRed Currant-Sma11, for preserves and pickles

Mikado, or Turuer's Hybrid-Very large, purplish red, potato leaf

Volunteer-Early; bright red, smooth and perfect in form

Red Cherry-An inch in diameter; borne in clusters; for pickle

Yellow Pear-Bright yellow, pear-shaped; used for preserves

Yellow Plum-Plum-shaped, yellow; for preserves and pickles.

Purple Peach

Crimson Cushion-Large, round and regular; bright red; seed cells sma11 and few

Ground Cherry, or Husk Tomato-Much liked for preserves and pies.

\section{SEEDS OF SWEET AND MEDICINAL HERBS.}

\begin{tabular}{|c|c|c|c|c|c|c|c|c|c|}
\hline Anise.. & $\$$ Pkt & $\begin{array}{r}\mathrm{Oz} \text {. } \\
\$ 0.15\end{array}$ & *Summer Savory & $\begin{array}{r}\text { Pkt. } \\
\$ 0.05\end{array}$ & $\begin{array}{r}\mathrm{Oz} . \\
\$ 0.15\end{array}$ & *Lavender. & & $\begin{array}{r}\text { Pkt. } \\
\$ 0.05\end{array}$ & $\begin{array}{r}\mathrm{Oz} . \\
\$ 0.25\end{array}$ \\
\hline Sweet Basil .............. & .05 & .15 & *Talragon .... & .05 & .25 & Marjorail & ㄱ. & .05 & .15 \\
\hline Coriander & .05 & .10 & *Wormwood & .05 & .15 & *Rue & 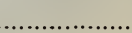 & .05 & .25 \\
\hline Dill ……............ & .05 & .10 & *Balm & .05 & .25 & Saffion & & .05 & .15 \\
\hline Fennel & .05 & .10 & Borage .......................... & .05 & .15 & Sorrel & …. & .05 & .25 \\
\hline *Rosemary & .05 & .25 & *Caraway ..... & .05 & .10 & *Thyme & $\ldots$. & .10 & .25 \\
\hline Sage & .05 & .15 & & & & & & & \\
\hline
\end{tabular}

*Perennial, and when once obtained in the garden, may be preserved for years.

\section{TURNIPS.}

One ounce will sow 150 feet of drill; I to $1 \frac{1}{2}$ pounds to acre. A valuable garden and farn crop; good Turnips are almost as desirable for table use as Potatoes; however, most easily affected in its form and flavor by soil, climate and mode of culture. There are many varieties, but we have selected the standard sorts. best adapted for garden and farm. Sow in drills fourteen inches apart and one-fourth inch deep, or sow broadcast. Ground should be thoroughly pulverized and rich. For the early spring and simmer crop. get them started as soon as possible, so thev may have grown to a sufficient size before hot weather. For the main crop, sow the get them started as soon as possible, so thev may have grown to a sufficient size before hot weather. For the main crop, sow the
middle of July to the last of August. For feeding stock in fall or winter, there is nothing superior to Turnips and Ruta Bagas, as they yield a larger amount of food than anything else on the same space of ground.

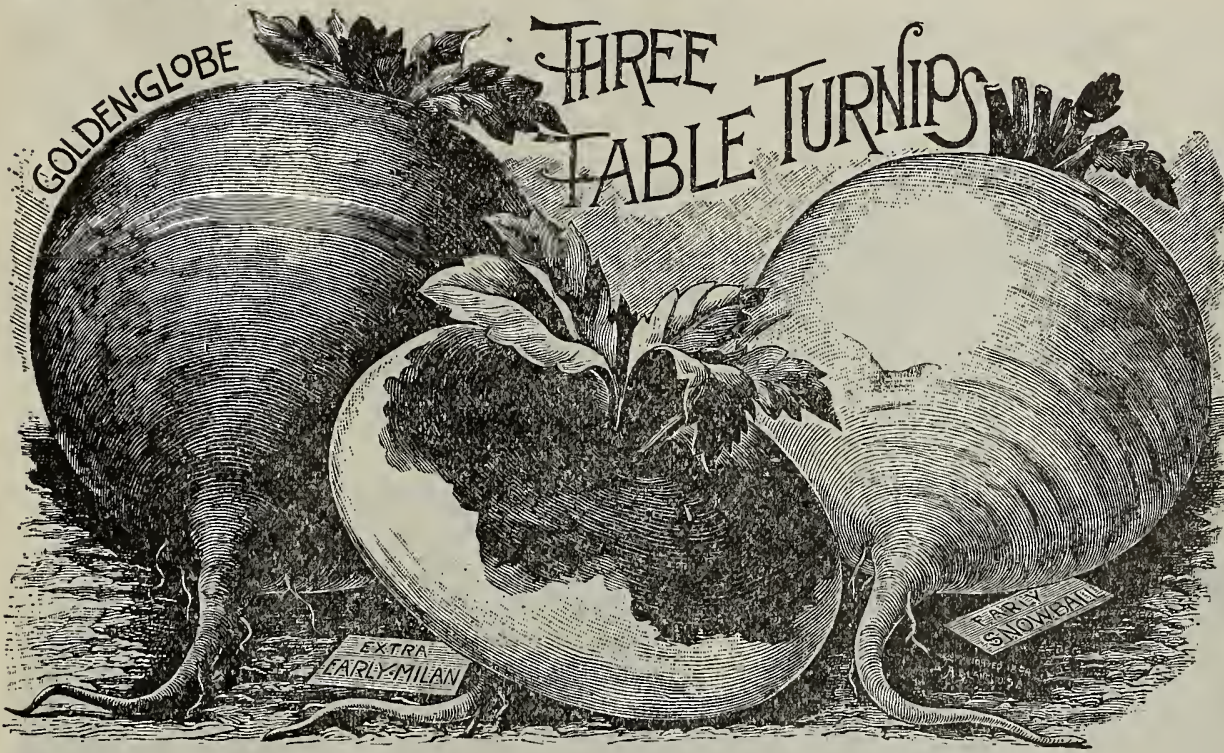

Extra Early Milan -A splendid early strap leaf variety; ready for use fully two weeks earlier than the Purple Top Strap Leaf. The bulb is of medium size, quite flat, smooth, and has a bright, fresh, purple top. Flesh is pure white, fine grained, sweet and jnicy. Pkt., 5c; oz., 10c; $\frac{1}{4} 1 \mathrm{~b} ., 20 \mathrm{c} ; 1 \mathrm{~b} ., 70 \mathrm{c}$.

Purple Top Strap Leaf-An old standard all-season variety without an equal.

\section{White Flat Dutch--} A well known early sort, largely used for spring sowing.

Prices, unless otherwise noted, pkt, 5c; oz., 10c; 1-4 lb., 15c: lb., 45c; postpaid.

By freight or express, purchaser's expense, deduct $10 \mathrm{c}$ per lb. Special prices on large quantities

Purple Top White Globe-An improvement on the Purple Top Strap Leaf; smooth, globular in shape; a great favorite with the market gardeners.

Early White Egg-Egg-shaped, pure white; a rapid grower of good quality.

Pomeranian White Globe-Largely used by stock-feeders; also fine for table use.

Yellow, or Amber Globe-Fine grained, yellow fleshed, very sweet. Skin a bright yellow; an ex-sosst cellent keeper.

Seven Top-For winter greens, produces a very small bulb, but is used extensively for the tops only, being very desirable for winter or early spring greens.

Purple Top Munich-An extra early flat Turnip; white skin below the ground and purple above.

We are Springfield Agents for Planet Jr. Garden Tools. Write for Catalogue. 


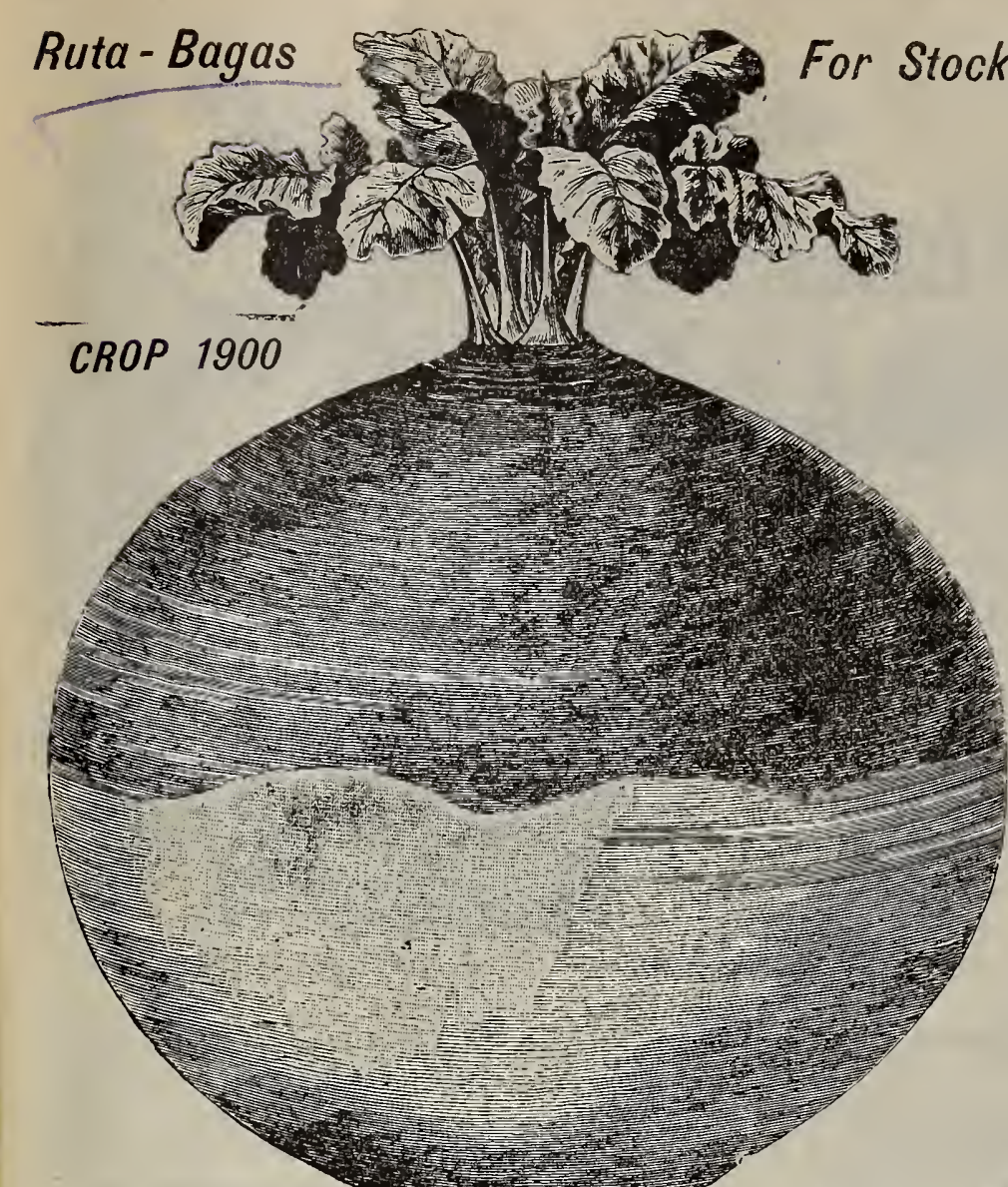

Try our tested American grown Turnip Seed.
Special prices on large quantities.

Anerican Purple Top-For years a great yielder and unsurpassed for stock feed. Tops sma11, bulbs very large; sweet and of the richest flavor.

Skirving's Purple Top-Attains an immense size; yellow flesh, fine flavor, solid and a very good keeper, very nutritious.

Laing's Improved Purple TopLeaves cabbage-1ike and large, bulb nearly round, skin smooth, yellow below the ground and purple above, flesh yellow, solid and of fine flavor.

Prices, postpaid, pkt., 5c; oz., 10c; 1-4 lb., 20c; lb., 45.c.

By express or freight, at purchaser's expense, deduct $10 \mathrm{c}$ per lb; Special prices on large quantities.

An eminent authority of agriculture has made the statement that nothing can compare with Ruta Bagas or Swedish Turnips for stock food; also very valauble for table use. An average yield of twenty tons per acre is common. They should be sown in light ground, enriched with well-rotted manure, in drills, rows $2 \frac{1}{2}$ feet apart, and thinned to six or eight inches apart in the rows. Cultivate thoroughly and returns will be highly satisfactory.

We are prepared to furnish large quantites of Turnip Seed, Eastern grown; prices furnished on application.

\section{LIKE PRODUCES LIKE-GOOD SEED, GOOD RESULTS.} TOBACCO.

Succeeds best and produces the best quality of leaf on a rich, sandy loam; while heavy new soils and green manures produce a coarse leaf. The best and most desirable fertilizers for the Tobacco Plant are wood ashes or commercial potash. The seed bed must be very light; sow seed early as possible after danger of frost is over; when about six inches high, transplant into rows four feet apart each way, and cultivate thoroughly with plow and hoe.

The Tobacco Seed we offer will be found to be of the highest quality and true to name. It comes from a competent Virginia grower and is produced only from selected crown shoots. Pkt., 5c; oz., 25c; $\frac{1}{4}$ lb., 70c; postpaid.

Connecticut Seed Leaf,

Sweet Orinoco,

Tuckahoe,
White Burley,

Missouri Broad Leaf,

Red Burley,
Yellow Prior,

Gold Finder,

Big Havana.

OUR TOBACCO SEED IS VIRGINIA GROWN, CROP OF 1900.

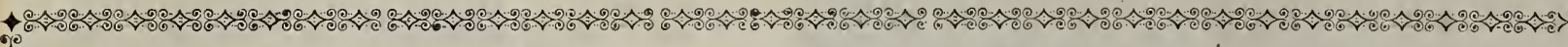

\section{FREE! FREE! FREE!}

How to get $\$ 150$ worth of Garden Seeds or save 25 per cent on your order.

See Page 3.

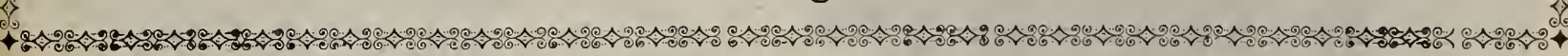

\section{NOTICE-TO MARKET GARDENERS AND LARGE GROWERS.}

Owing to short crop conditions on some varieties of Peas and Beaus, Dwarf Champion Tomatoes, Wakefield Cabbage and Wethersfield Onion, would suggest that you place your order early. 


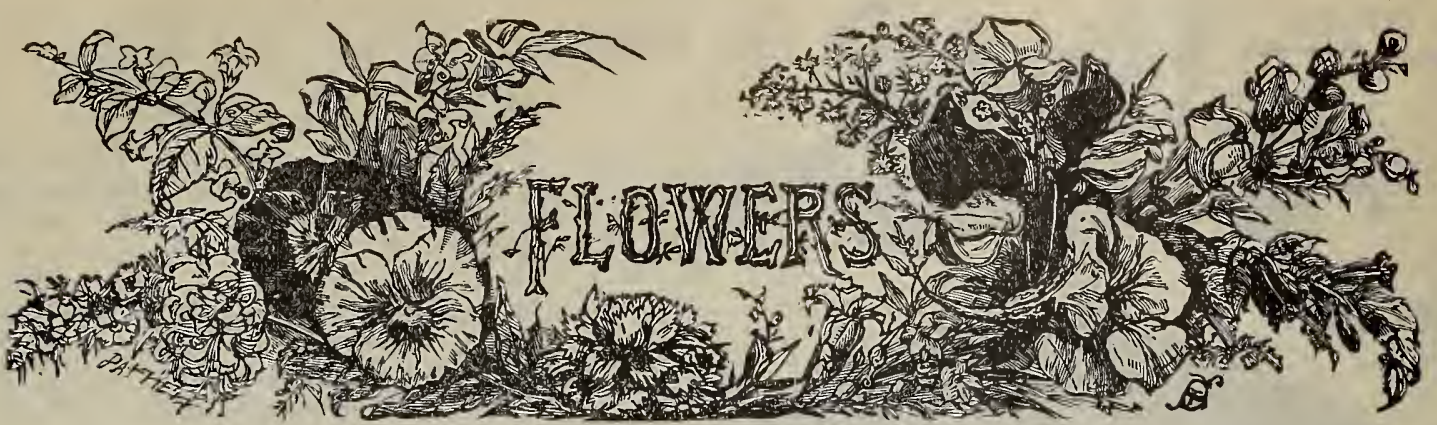

In the cultivation of flowers from the seed, success depends largely upon the soil and the care exercised in the preparation of your beds. Moisture and light are absolutely essential; a few varieties are partial to shady spots. Most seeds germinate best in a light, sandy loam, while a few are benefitied and do best in a heavier soil. The hardy sorts should be planted as early in the spring as the soil can be worked, many times it being best to heat or bake the soil, thereby killing all the insects. Have your seed-bed level, very rich and finely worked, sow tlie seed and cover lightly.

The soil should never beconie dry. Keep the bed moist. After the plants are up, care must be taken to give them plenty of light and air, When the second leaves appear, transplant to pots, open ground or new beds as may be required. Keep shady and water frequently until well established. Remember poor care will result in poor flowers.

Acroclinium-Handsome daisy-like flowers, Exquisite. Probably the most beautiful everlasting known. Double flowering, mixed. Pkt., 5c.

Ageratum - A plant bushy in appearance, a long and profuse bloomer. Compact in habit and exactly suited for edging. Not even the Petunia will give a greater quantity of bloom or last longer in flower. Colors, blue and pure white. Pkt., 5c.

Adlumia (Mountain Fringe or Alleghany Vine)-A biennial with beautiful fern-1ike foliage of light green color. Flowers pink and white. A climber and thrives best partly shaded. Pkt., 5c.

Amaranthus-Rapid-growing plant having striking and handsome colored foliage. Mixed colors. Pkt., 5c.

Ampelopsis Veitchi-A very hardy perennial climber; will cling to walls of wood, brick or stone. Foliage exceedingly dense and of a glossy, rich green, in autumn changing to bright red and yellow. Pkt, 5c.

Wild Cucumber---Produces an abundance of vine; for trellises or screens it is indispensable. Very ornamenta1; a rapid grower; fruit borne in profusion and a deep sea-green color, when ripe turns to a dark orange. Pkt., 5c.

Antirrhinum, or Snapdragon-A half-hardy perennial, flowering freely the first season. Forms dwarf, compact plants, which bear an enormous quantity of large flowers, of many"brilliant and dazzling colors. Grows readily from cuttings. Pkt., 5c.

Alyssum-A favorite little annual especially adapted for beds and edgings. $\square$ Very fragrant and a profuse bloomer. Easily grown, spreads rapidly and forms in a thick mat of blue white sweet-scented flowers. Pkt., 5c.

\section{ASTERS.}

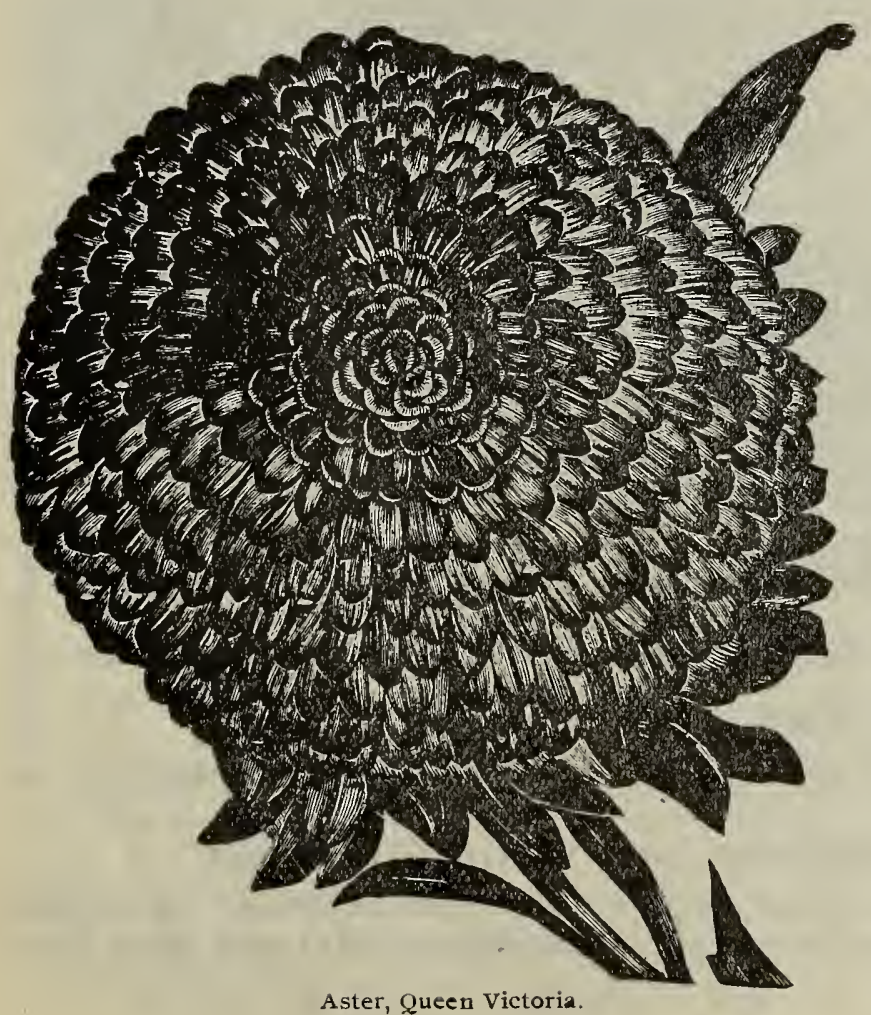

An annual that can be relied upon for a grand display are passiune flowers in the fall months when other varietie are passing away; exquisite colors and almost perfect form Seeds can be sown in hot-beds early and transplanted, or mally sown in open ground in hot weather. Mulch liberbeing ime several forms of Asters, some others incurved like a Chrysantheinum loose like a Peony

Mignon Astei's-A new sort, semi-dwarf in habit, very double flowers, with deeply imbricated petals. Mixed colors. Plkt., 5c.

Improved Victoria-Large flowers and very double; possibly the handsomest variety of all Asters. Colors are extremely delicate and of many shades. Mixed colors. Pkt., 5c.

German Quilled-Large double flowers composed of tubes or quill-shaped petals. Mixed colors. Pkt., 5c.

Peony-Flowered Perfection.-Very large globular flowers of perfect form with incurved petals. Many exquisite colors, rich and brilliant. A magnificent variety. Mixed colors. Pkt., 5c.

Special Mixture of Tall Aster's-Made up of the most desirable colors of Victoria, Perfection, Crown, Mignon and others. Will make a handsome bed. Pkt., $5 \mathrm{c}$.

$A N N U A L S$ grow, bloom and die the first year from the

$B I E N N I A L S$ flower the second year, often the third year, then die.

PERENNIALS bloom the second season and usually continue for several years. 


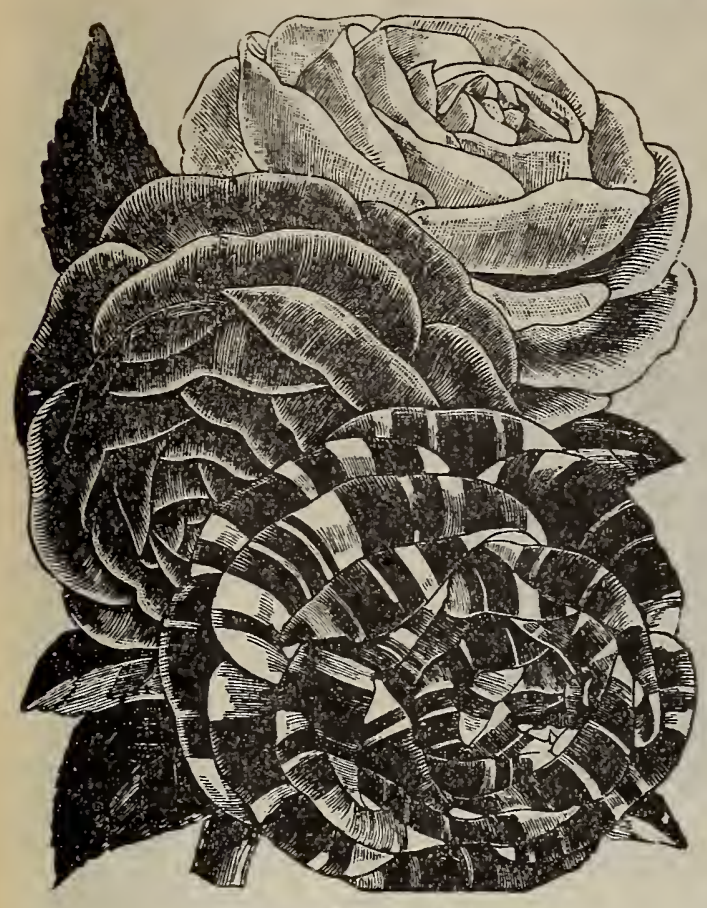

Improved Balsams.

CENTAUREA-An annual and an old favorite, very popular for cut flowers.

Centaurea Cyanus-Mixed colors. Pkt., 5c.

Cornflower-Pkt, , 5c.

Bluebottle--Pkt., 5c.

Bachelor's Button-Pkt., 5c.

COLEUS-The most popular and well known foliage plant grown; finely variegated foliage of striking beauty and many colors. Easily grown from the seed. Sow early in the spring, transplant to beds or borders.

Coleus-Fine hybrid, mixed. Pkt., 10c.

DISCOUNTS_A11 purchasers of Flower Seeds in packets and ounces are entitled to liberal discounts. See order sheet and third page of this catalogue.

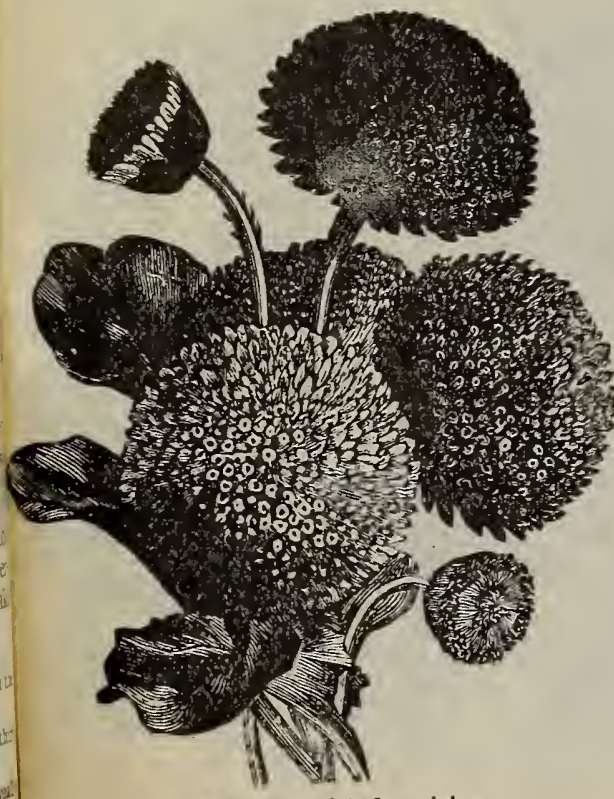

Deuble Quilled Daisies.
Balsam (Touch-1Ee-Nots)-Double Camelia-flowered. Showy annuals that are universal favorites. Perfect double flowers of brilliant colors borne in wonderful profusion. Seed may be started in hot-beds early or sown in the open ground. For perfection should be transplanted into very rich soil. Pkt., 5c.

Balsam Pear and Apple-Very curious climber with ornamental foliage and golden yellow fruit, which opens when ripe, showing the seed and rich carmine interior. Mixed. Pkt.. 5c.

Balloon Vine-Rapid-growing annual; a climber with peculiar capsules; often reaches five feet if grown in warm soil. Flowers white. Pkt., 5c.

Bellis (or Double Daisy)-Next to the Pansy. it is the most charıning garden flower, and if given a cool, moist, shady location, will bloom all summer. An excellent pot-plant for winter blooming. Flowers are double, and appear very early in the spring if slightly protected over winter. Pkt., 5c.

Merchants not receiving our wholesale price card of Field Seeds, Grass Seeds, Onion Sets, etc., are requested to write for same. We give you prompt service and save you freights.

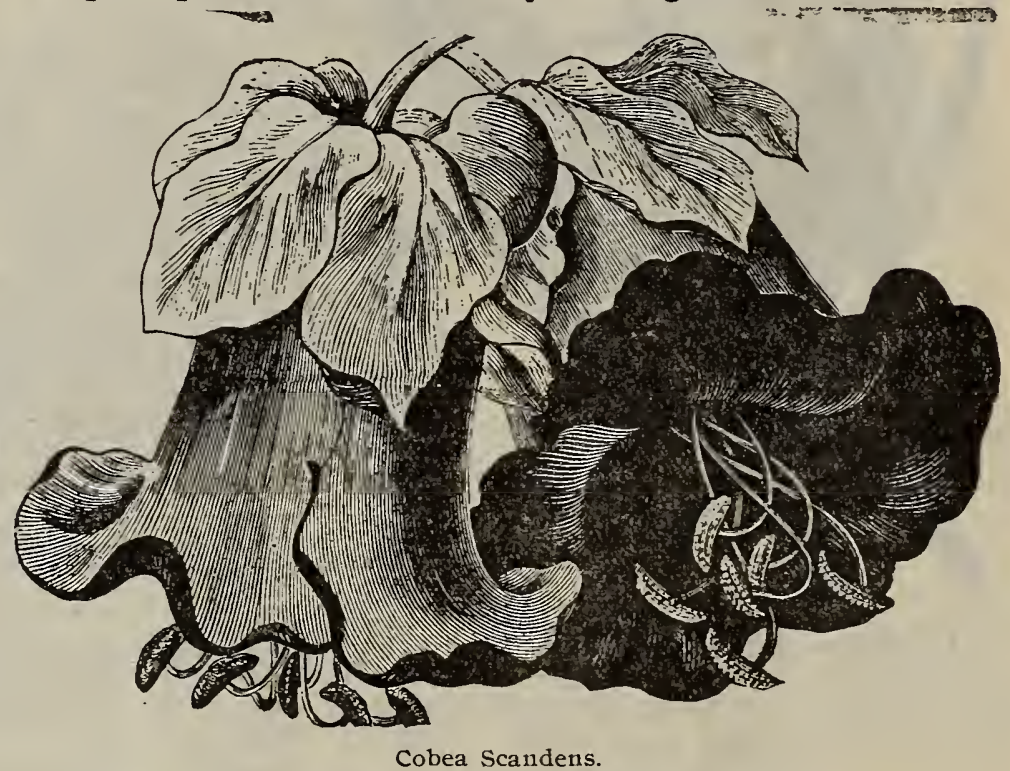

Cobea Scaudeus-A climber of great value; excellent for out-of-door as well as house culture, very pretty foliage and large, beautiful, bell-shaped flowers that open a bright green, turning to a purplish hue. Pkt., 5c.

Celosia (or Cox comb)-A very common garden flower, but somewhat improved of late years; large and of the most gorgeous color, largely used for late season and autumn bedding. Sow in hotbed and transplant to open ground after danger of frost is past. Pkt., 5c.

SIZE OF PACKETS-OUT packets are large in size. packets are large in size, containing, in man are more seeds than are needed for the
home garden,

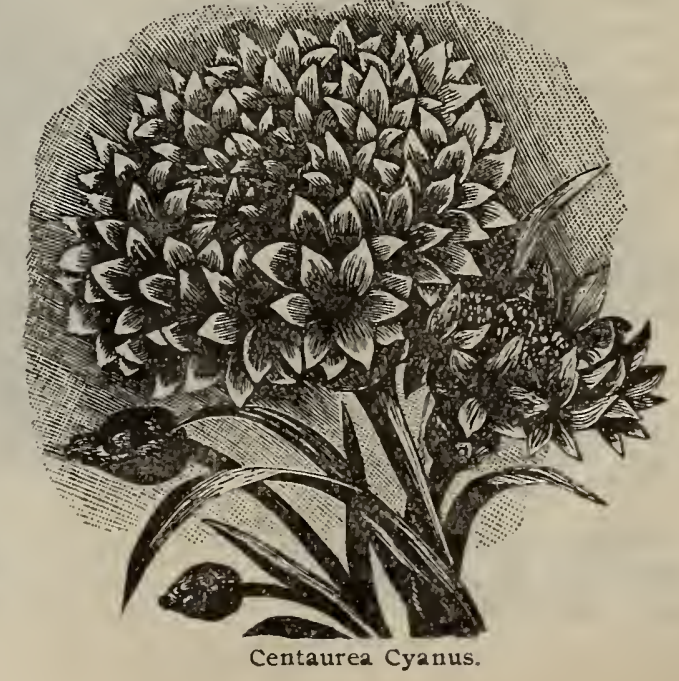




\section{CARNATION'S.}

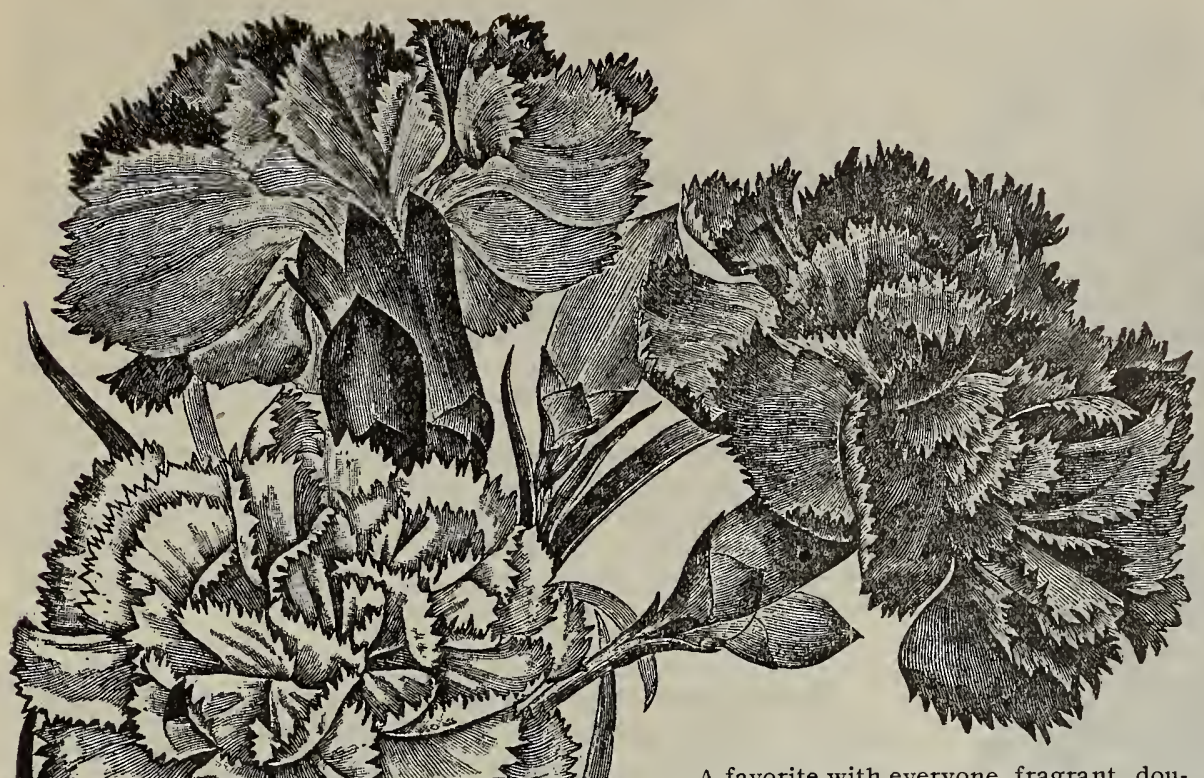

Marguerite Carnation-The most important seed novelty produced in many years; valuable for flower beds in summer as well as winter blooming, producing beautiful double flowers in three to four months from the seed. Plants dwarf and flowers abundantly in a great variety of colors, striped, mottled, variegated, delicious1y fragrant. Mixed. Pkt., $5 \mathrm{c}$.

Carnations-Fine mixed. Pkt., $5 \mathrm{c}$.

Carnations.--Double mixed. Pkt., 5c.

\section{FOR CONSTANT BLOOM.}

Sweet Alvssum, Candytuft, Carnation, Celosia, Nasturtium, Petunia, Phlox Drummondii, A favorite with everyone, fragrant, dou- Pinks, Portulacca, Sweet Peas, ble flowers of elegant form and exquisite Verbena, Zinnia.

markings.

Chinese Lantern Plant-A magnificent plant for the garden as well as for pots both winter and summer. A very unique and novel plant of striking beauty. A perennial. May be wintered in the cellar or used as a window plant. Produces large husks at first of a beautiful green color, changing to yellowish hue, then to bright scarlet. In the husk a fruit is borne, similar to a Husk Tomato. Foliage 1uxuriant. Pkt., $5 \mathrm{c}$.

Cypress Vine-One of the finest and most attractive vines for training to small trellises. Beautiful feathery foliage of a dark green color, dotted here and there with little exquisite velvety flowers. Mixed colors. Pkt., 5c.

Cypress Vine, separate colors, Pkt., 5c.

\section{DWARF GROWING PLANTS FOR BEDS AND EDGINGS.}

Ageratum, Alyssum, Calliopsis, Campanula, Candytuft, Chrysanthemum, Daisy, Dianthus, Escholtzia, Forget-Me-Not, Heliotrope, Mignonette, Marigold, Dwarf Nasturtium. Dwarf Pansy, Phlox Drummondii, Poppy, Portu-
lacca, Verbena, Zinnia Dwarf.

Cosmos-An elegant fall flower. Sow seed early in the spring and plants will bear a profusion of attractive blooms from September to November. Give them a rich soil and support each plant, as the tops are rather heavy. Often reaches a height of seven feet. Foliage dark green and feathery or fern-like. Daisy-like flowers of many colors. Mixed. Pkt., 5c.

Cyperus Alternifolius (or Umbrella Plant)-A strikingly handsome foliage plant, well adapted for house or culture in open ground. Leaves very dark green and radiate from the stem and curve downward in graceful fashion. Easily raised from seed. Pkt., 5c

FOR FRAGRANT FLOWERS.

Sweet Alyssum Candytuft, Carnation, Four o'clock, Heliotrope Mignonette, Pansy, Nasturtium, Stocks, Sweet Peas, Verbena.

Climbing Plants for Porches, Trellises, Etc.

Adlumia, Balloon Vine, Cypress Vine, Moonflower, Nasturtium Tall, Sweet Peas.

Flower Seeds, ro vari= eties, one $5 \mathrm{c} \mathrm{pkt}$. each, for 25 , postpaid.

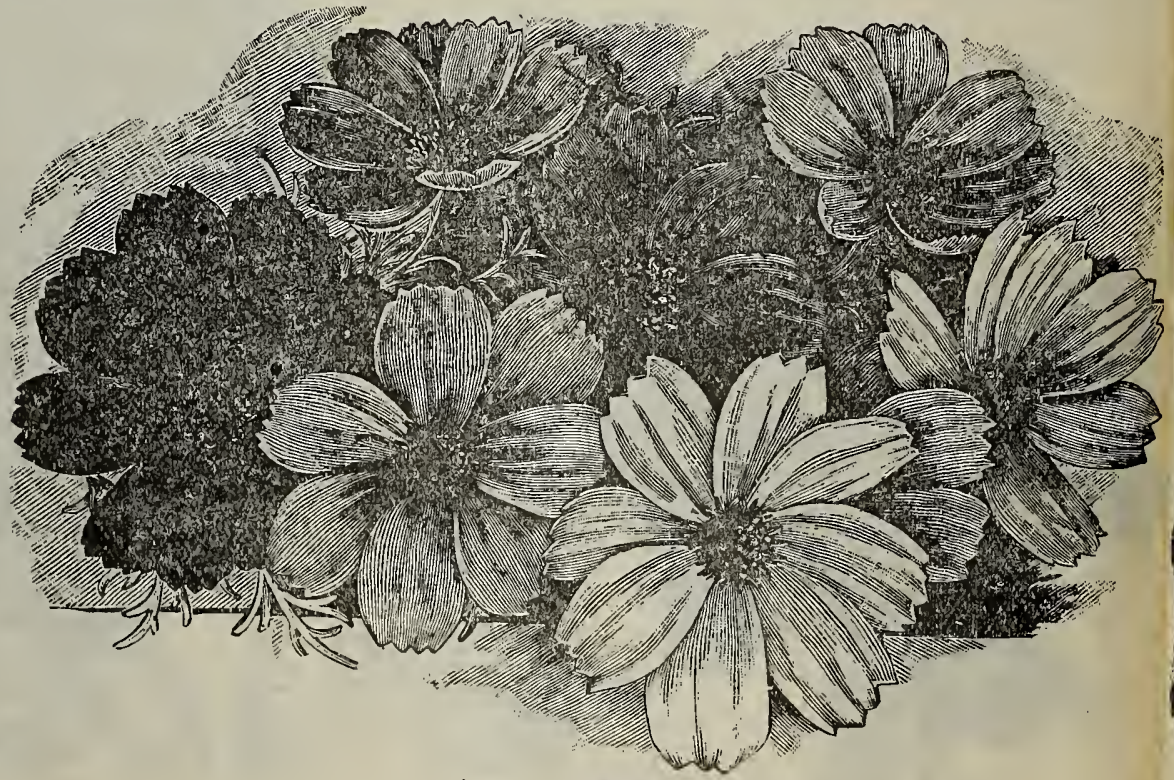

iroup of cosmos 


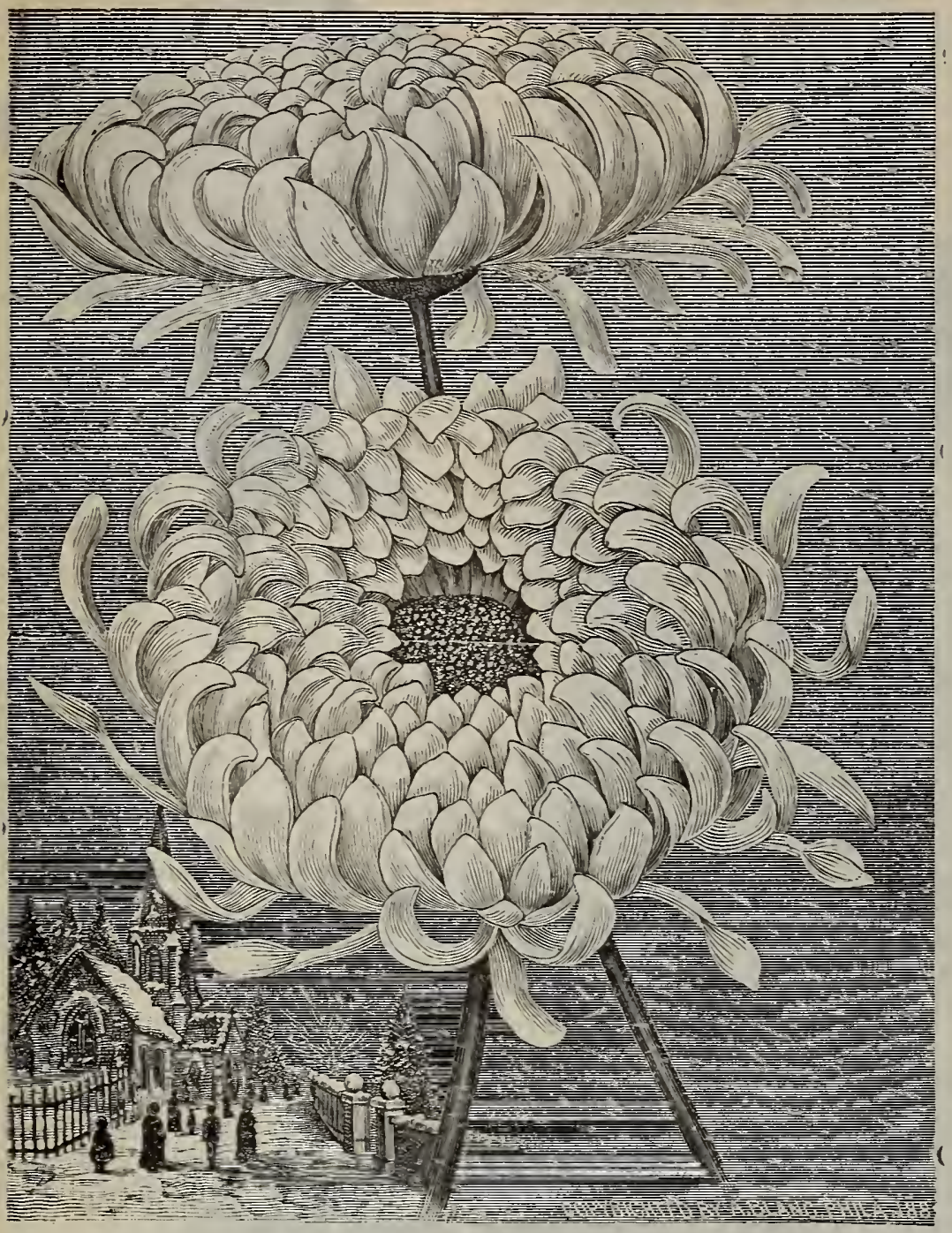

Chrysanthemum
Chrysanthemum-Chrysanthemum seed sown in the spring will produce large, vigorous plants by fall, which will fiower abundantly. No other annual furnishes such a magnificent array as to color, shape and size. Easily raised, seeds germinate quickly, and plants, being hardy, make a rapid growth; it requires very rich soil. Pkt., 5c.

Calliopsis (or Coreopsis)-One of the brightest and richest of our annuals. Produces a great quantity of most charming flowers, poised on long stalks. Adapted for cut flowers and bouquets. Sow seed in open ground as early as possible. Pkt., $5 \mathrm{c}$

Campanula.-Beautiful plants for house or border culture. Large bell-shaped flowers. Sow in open ground, cover lightly. Mixed colors. Pkt., 5c.

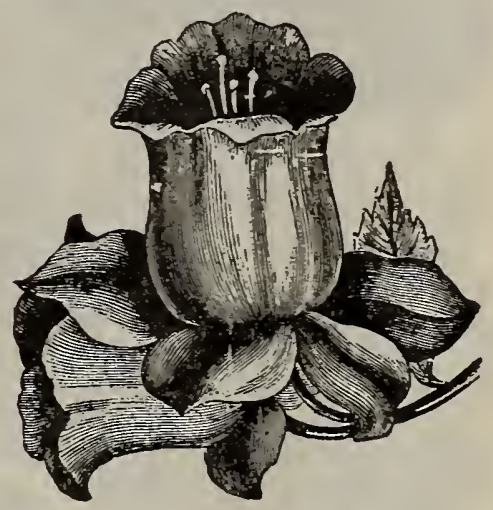

Campanula, Single.

\section{Poor Care Will Result in Poor} Flowers.

\section{DIANTHUS (Or Garden Pink).}

A very near relative to the Carnation of many varieties and many bright and delicate colors. One of the most popular flowers in cultivation; possessing a vivid beauty impossible to describe. Delicately and deliciously sweet scented Succeeds well in pots for winter culture, or sow early in spring in hot-beds and transplant into open $€$ round. Will bloom the first season; some will stand the winter and bloom again a nother year, more beautiful than before.

Dianthus Chinensis (Double China or Indian Pink)-Mixed. Pkt., šc.

Dianthus Heddewigii (Double Japan Pink)-Large flowers. Mixed colors. Pkt., jc.

Dianthus Barbatus (Single Sweet William)--A matchless border plant. Very sweet scented. Colors vivid and varied. Mixed. Pkt., jc.

Dianthus Barbatus (Double Sweet William)-Enormous in size and double. Mixed colors. Pkt., 5c.

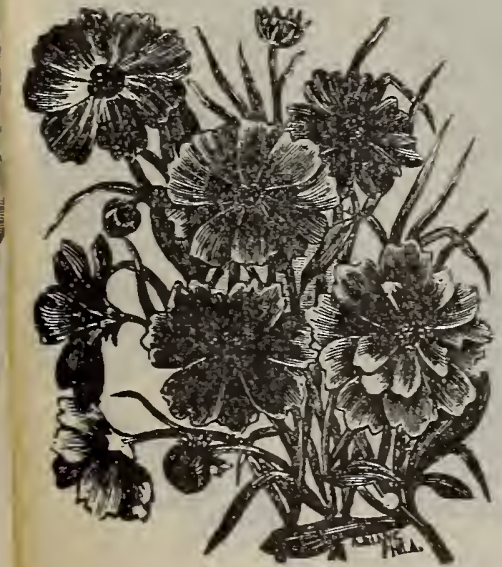

Calliopsis.
Delphinium (or Larkspur) -A handsome, well-known hardy perennial. Excellent for permanent beds or borders Fine curiously cut foliage, usually delicate and pretty colors, ranging through all shades of lavender, azure blue, medium and dark. Sow seed in autumn or very early in the spring. Will bloom first season. Pkt., Jc.

\section{Tall Growing Plants :for Back} grounds and Centers.

Antirrhinum, Asters, Balsam. Datura, Delphinium, Hollyhock, Helianthus, Narigold, Mirabilis, Sa
Stocks, Sweet William, Zinnia.

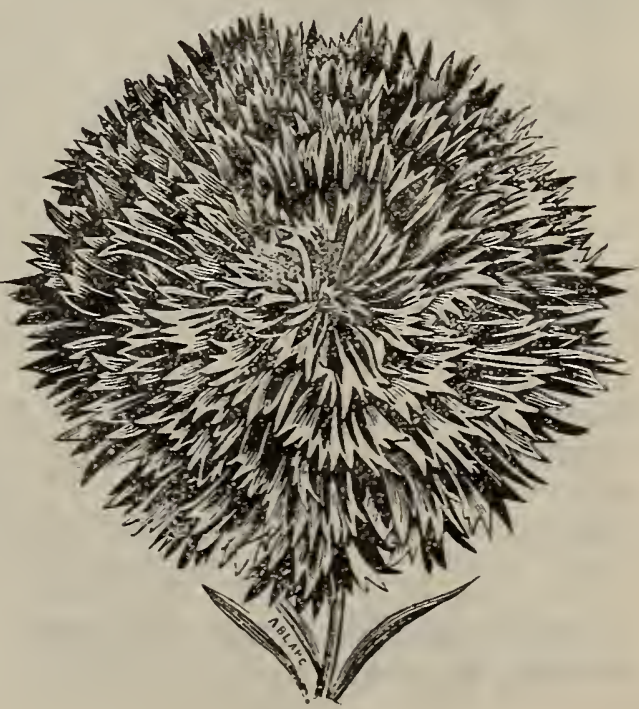

Dianthus, 


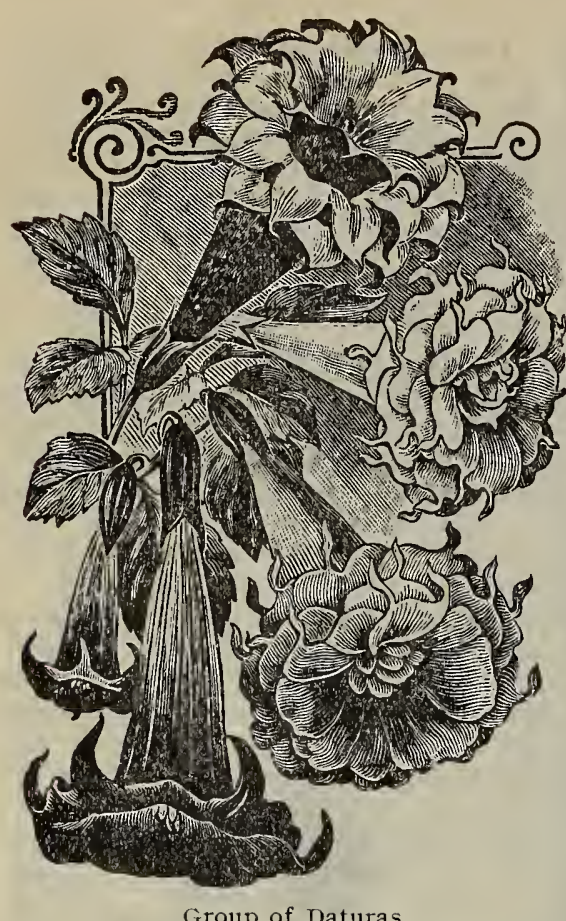

Group of Daturas.
Dahlia-Fall blooming outdoor plant and admired by everyone. Seeds should be sown very early. Many of the finest and with the richest colors are grown from the seed. Give a very rich soi! an abundance of water. Double mixed. Pkt., 5c.

Datura (or Trumpet Flower) -A superb flower for the garden, also well adapted as a pot-plant, both for summer and winter. Trumpet-shaped, double and very fragrant; blooms in two or three months from the seed. Compact in habit. Double mixed. Pkt., $5 c$.

Iberis (or Candytuft)-A fine old garden annual, e-x cellent for edgings and beds; ind ispensable for cut flowers. Sow very early in open gronnd and keep the seed heads pinched off for a succession of bloom. Mixed colors. Pkt., 5c.

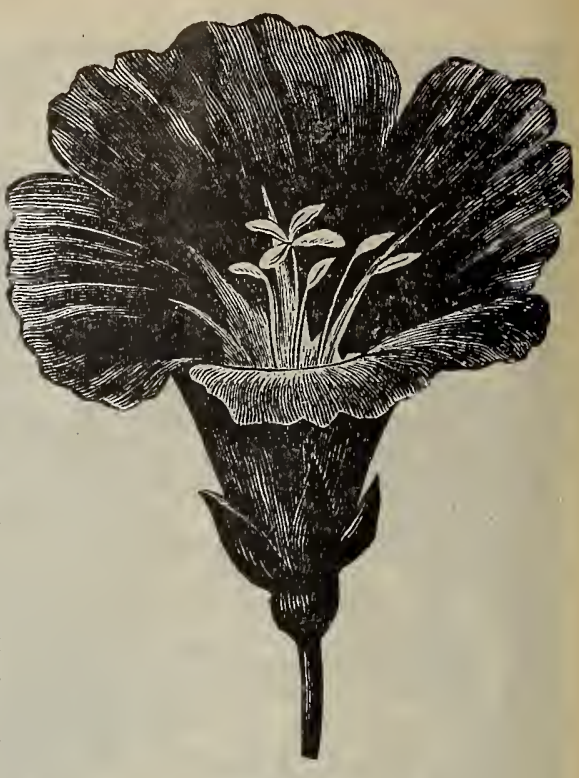

Godetia.

Escholtzia (California Poppy)-One of the hardiest and most easily grown annuals, showy, grows rapidly, coming into bloom soon after the plants are above the ground. Color yellow, orange or white, foliage finely cut and exceedingly handsome. Mixed colors. Pkt., 5c.

Feverfew-Fine border plants that are always in flower; bloom quickly from seed and are extra good for cutting. Flowers are large and double, dwarf and compact plants. Mixed colors. Pkt., 5c.

Geranium-Although perennial, will produce fine plants and flowers the first season from the seed of many striking shades. One of the most popular plants either for out-door or pot culture; will thrive best in partly shaded location. Mixed colors. Pkt., 5c.

Godetia (or Satin Flower)-A plant particutarly adapted for culture in a shady place; very handsome foliage, flowers large and wide-open, of shining, satin texture and of a most delicate and lovely color. Mixed colors. Pkt., 5c.

Gourds. - Well-known climbers; rapid in growth and luxuriant foliage. Nothing better for covering arbors, trellises, etc, Bear fruit of a fantastic and grotesque nature; many prettily striped and oddly crooked. Mixed sorts. Pkt., 5c.

Gomphrena-An excellent and attractive garden plant, which bears great quantities of clover-1ike blossoms, different in appearance from any other everlasting. Extra fine for winter bouquets. Remove the soft, downy covering from the seeds and start under glass. Mixed colors. Pkt., 5c.

\section{FOR BOUQUETS AND CUTTINGS.}

10 PACKETS, ONLY 25c, POSTPAID.

10 choice Annuals, the very best seed and most adapted for cutting and bouquets, one packet each of

Asteris,

Candytuft,

Sweet Alyssum, Kinnia,

Ageratum,

Balsan,

Nasturtium,

Pansy,

Carnation,

Sweet Peas.

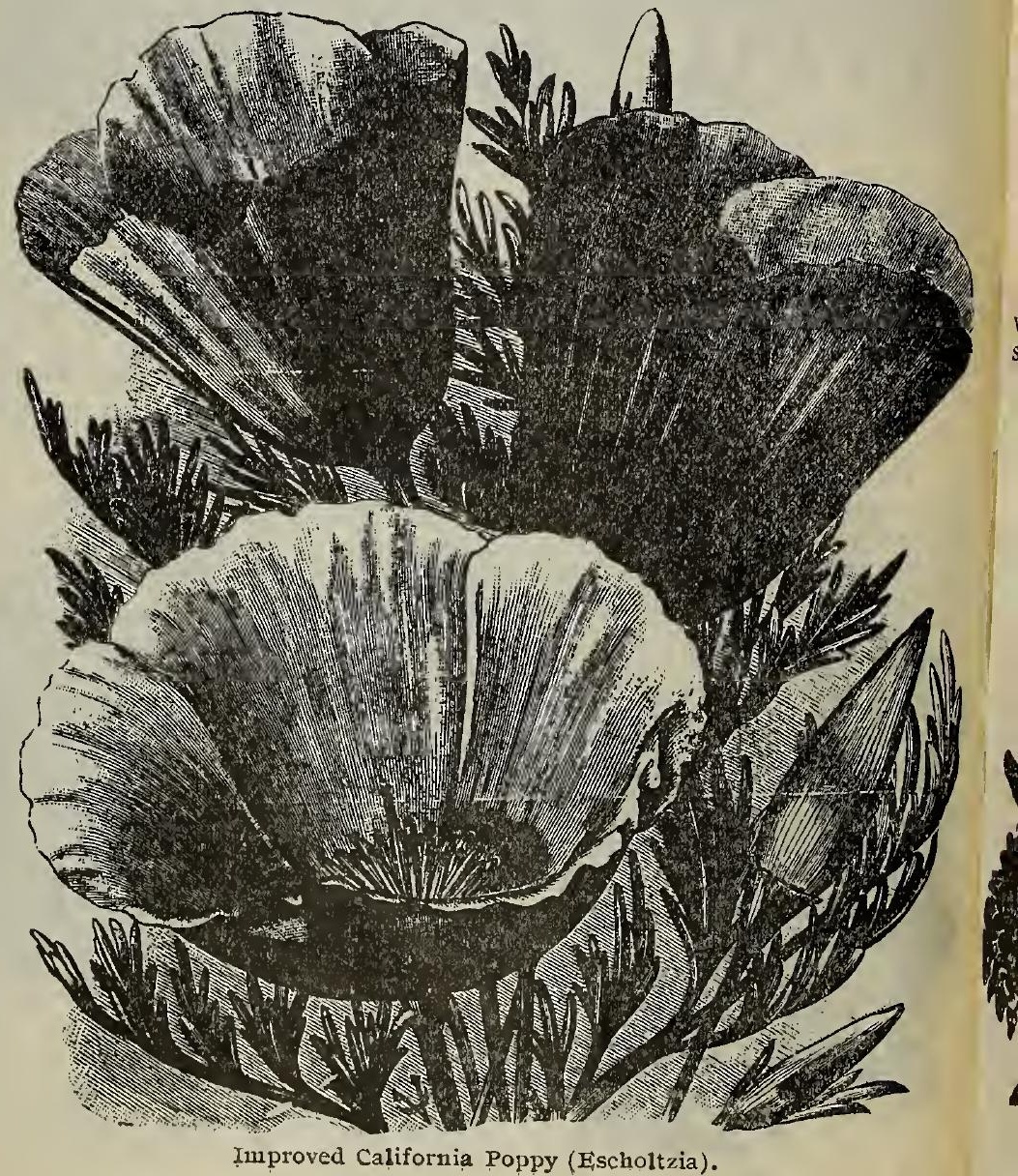

All Flower Seeds will be sent postpaid at prices, 


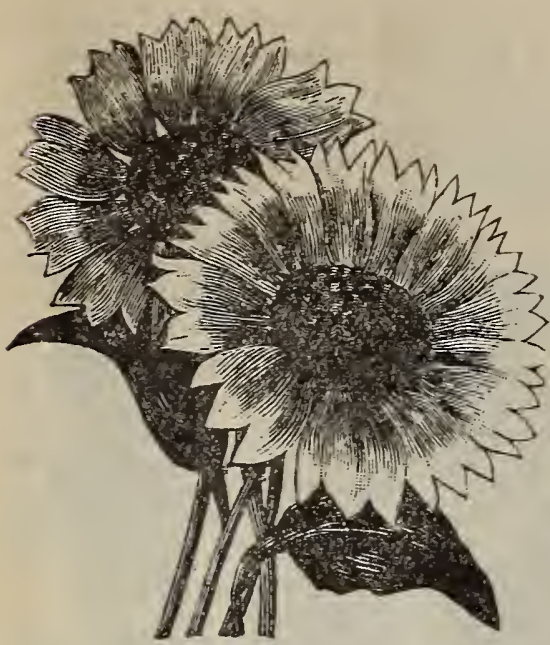

Hollyhocks--One of ths finest and most showy perennials; bears pyramidal spikes of large rosettelike flowers of all colors, from pure white to almost black. Mixed. Pkt. 5 c.

Heliotrope-Grows readily and rapidly from seed; blooming in very short time. Will bloom all summer in the garden or all year round in the house. Colors from blue-black to almost pure white. Very fragrant. Pkt., 5c.

Ipomea (or Moonflower) Closely allied to the Morning Glory. but very much larger and probabiy more exquisite in color. Of rapid growth, handsome foliage. Flowers often four or five inches in diameter with a fire-pointed star in the center. Usually open at dusk or earlier on cloudy days. Very fragrant. Start seed under glass, transplant as early as safe in the spring. Colors white and blue. Pkt., 5c.

Note our Special Offer. Any ten varieties Flower Seed, your own selection, for $25 \mathrm{cts}$, postpaid.

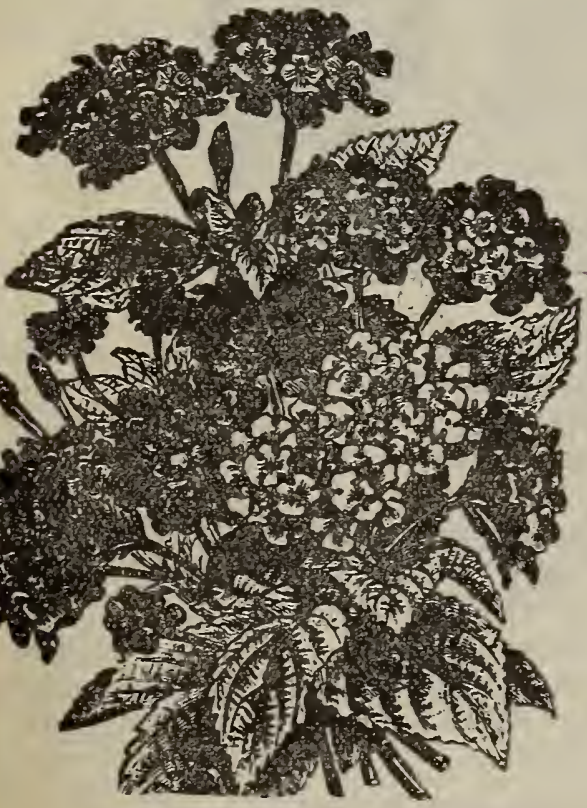

Lantana.
Gaillardia-Often and very appropriately called the Chrysanthemum Gaillardia, owing to their large size and great brilliancy of color; very double; flowers borne in great profusion. Well adapted to pot culture. Will thrive in any soil. Pkt., ǰc.

Helianthus (or Sunflower)-A miniature Sunflower of a bright yellow color with dark center. Very useful for decorative purposes, fine foliage; plants dwarf and bushy. Pkt., šc.

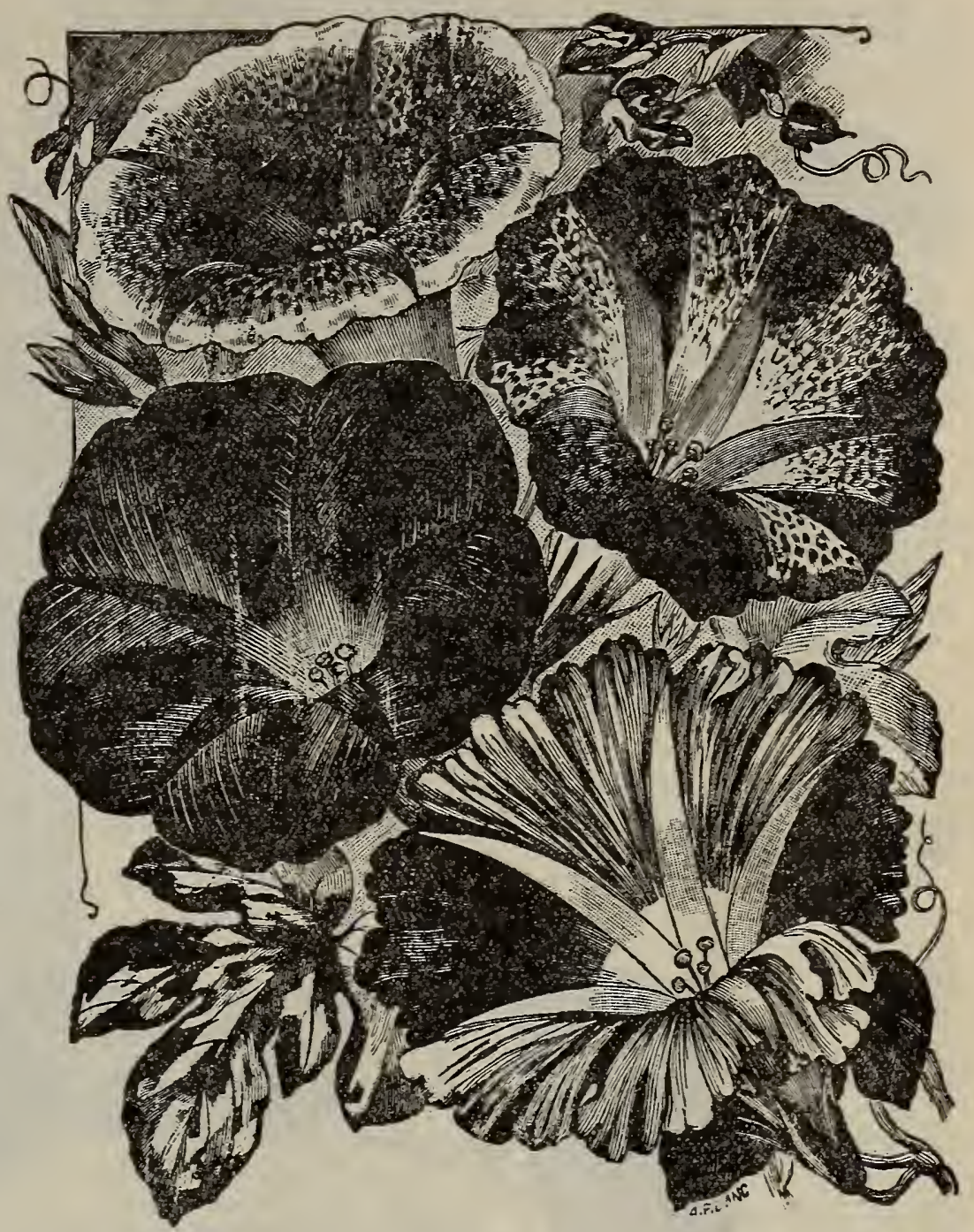

Japanese Morning Glory.

Japanese Morning Glory-Foliage magnificent and variegated, large and heart-shaped; very striking and ornamental Howers, almost double the size of the ordinary sort: colors exquisite, running from pearly white through all possible shades of blue and red, from pink to darkest purple; some are streaked and mottled, while others are deep purple, with clear white edge. Sow early in rich soil and water freely. Pkt., 5c.

Lantana-Seed a little slow to germinate, but grows rapid1y when once started and soon makes thrifty plants. Rather dwarf in habit, Blooms in large Verbena-like clusters, variously colored, with a spicy fragrance. Flowers change color with age, and are succeeded by deep blue berries. Pkt,, $5 \mathrm{c}$.

Lobelia-Charming little plants for small beds or edginors; also fine for winter culture; bloom in five to six weeks from seed; of delicate and graceful foliagre. Mixed colors. Pkt., 5c.

Myosotis (or Forget-Me-Not)-Beautiful for shady nooks or beds; though perennials, they bloom the first season. Excellent for a shady window where few plants will bloom. Pkt., 5c.

Mirabilis (or Four o' Clock)-Blooms in the afternoon with strict regularity, hence its name. Profuse and exquisite flowers of the most dazzling colors, exhaling a delicious perfume. Pkt., $5 \mathrm{c}$. 
Mignonette-The hardiest annual in cultivation and a universal favorite for its sweet and delicate fragrance. Sow early in the open ground for summer blooming, and in pots any time for the window. Pkt., 5c.

Nigella (or Love-in-a-Mist)-A pretty little dwarf annual; foliage feathery and fern-like, in which large double charming blossons are set; very hardy, double, blue and white mixed. Pkt., 5c.

\section{NASTURTIUM.}

Showy popular annuals, succeed under any circumstances; heat or drouth does not seem to affect them. They make a very charming effect; intensely bright and beautiful flowers, borne profusely the whole season. Leaves are leathery and dark green.

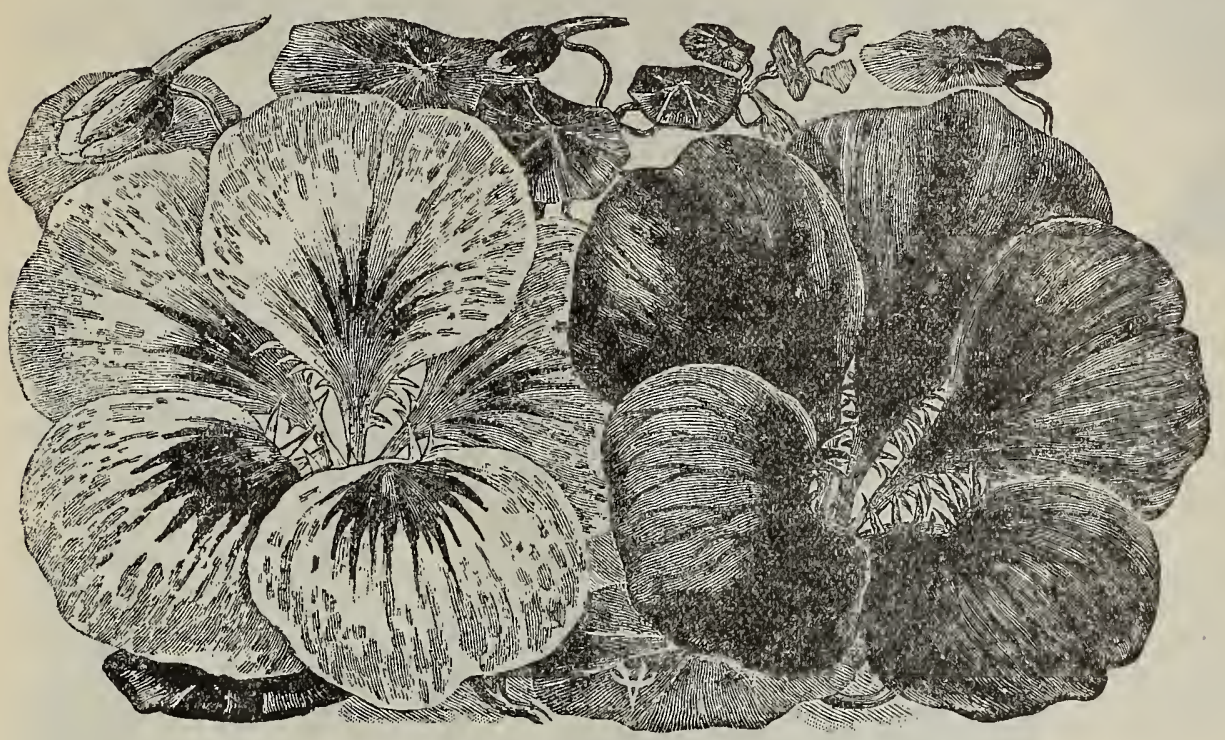

Tall NasturtiumBeautiful and luxuriant climbers, for trellises and arbors, bearing their gorgeous and sweet scented flowers in great profusion. Mixed colors. Plkt., 5c.

Dwarf Nasturtium -One of the showiest and most popular annuals; forming compact plants, exquisite flowers of all colors. Mixed colors. Pkt., 5c.

King of the 'Yom Thumb.-A striking and very sweet scented Nasturtium. Crimson. Pkt., 5c.

Nasturtiums.

Vadame Guenther's Hybrids-A new strain of extra large flowered, elegantly blotched and marked sorts. Many different colors and shades appear among them. All of striking and peculiar beauty aud rich foliage. Mixed colors. Pkt., 5c.

\section{PHLOX.}

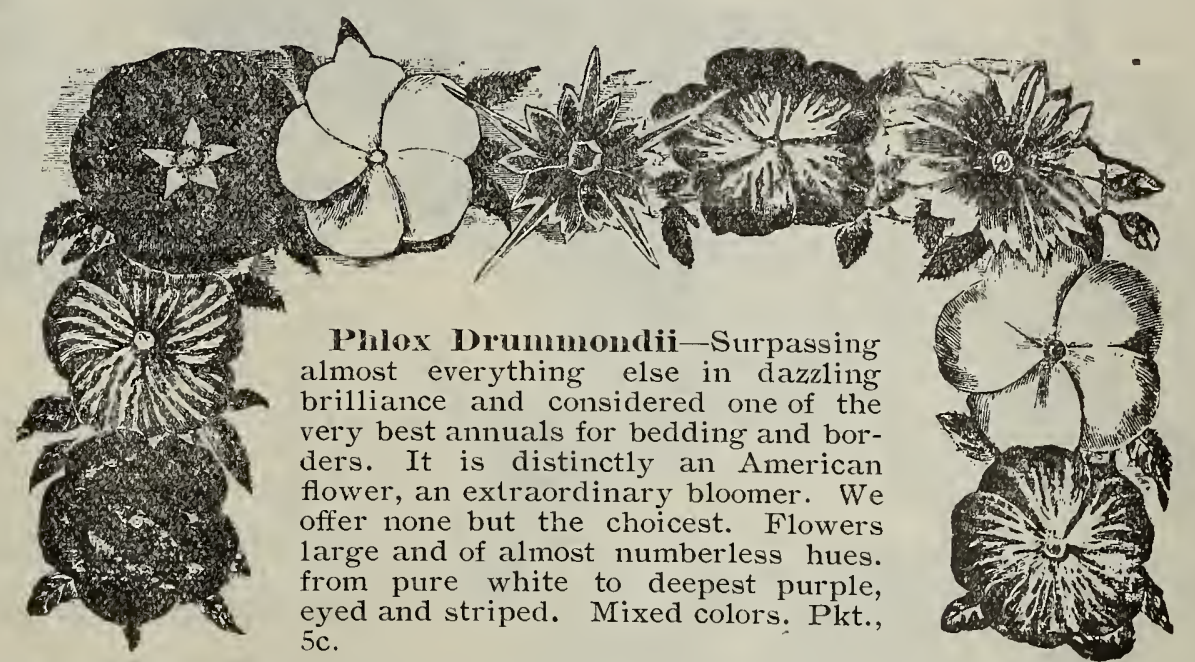

Phlox Quedlinberg (or Star Phlox)-The center of each petal runs out to a point beyond the edge, whi which gives the flower a regular star-like form. Plants compact. Mixed colors. Pkt., 5c.

Platycodon-Blooms first year from seed, though it is a hardy perennial, the plants living in ${ }^{\circ}$ the $\mathrm{Pkt}$ ground over winter and blooming profusely year after year. Large, pretty, star-like flowers, colors very bright and clear. Mixed colors: Pkt., 5c.

We would call your attention to the fact that a great many are unsuccessful in getting flower seed to germinate properly from the fact that it is very often planted too deep. Those inexperienced in growing able plants from the seed should always read carefully the cultural instruction on the packet.

Try our Mixed Lawn Grass for a good lawn. Put up in one pound cartons; per 1b., Pe $25 \mathrm{c}$; per bushel in bulk, $\$ 3.50$.

We deliver free, direct to consumer, Vegetable Seeds, Flower Seeds and Bulbs, except where noted. 


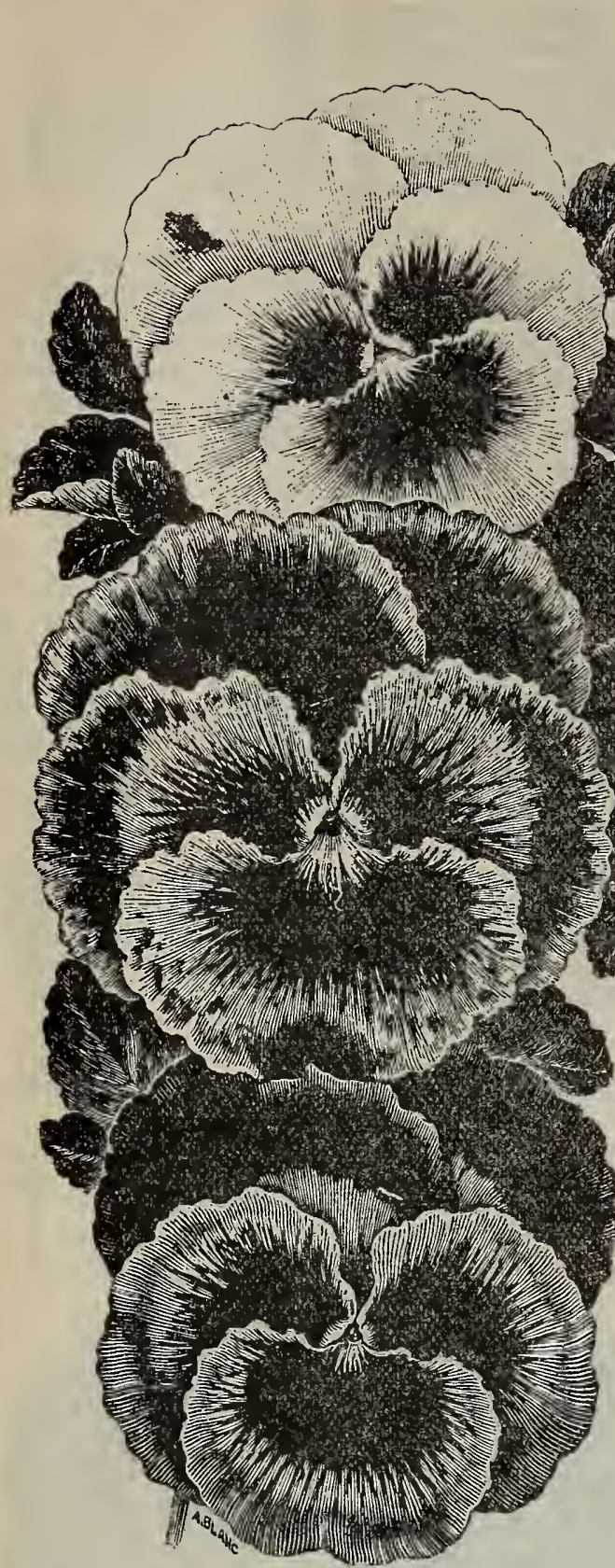

PANSIES.

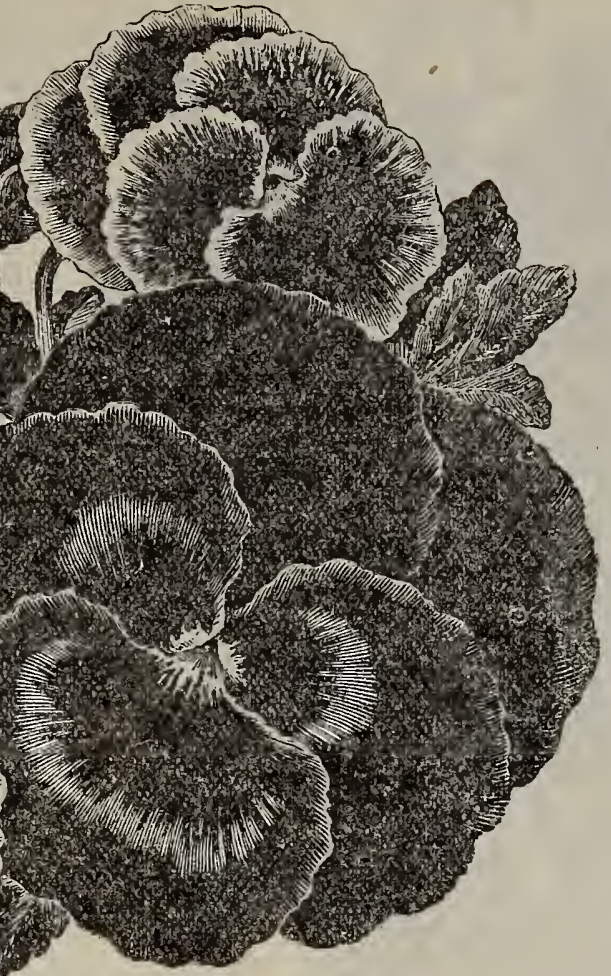

Pansy Culture.

Pansy seed for fall sowing should be sown in hot-bed or cold frame, even in the open ground if somewhat protected; ground should be thoroughly pulverized and espe-
cial care taken that seed is cial care taken that seed is
very slightly covered. After plants show three to four leaves, should be transplanted in rows three to four inches apart. Best results are obtained in out-door culture by planting in cool, deep, moist beds. partially shaded from the afternoon sun. Nothing is more beautiful or pays better for the time and labor expended than a good Pansy bed.

\section{Selections of Pansies}

Giant Mixed-Pkt. 10c.

Common MixedPkt., 5c.

Select any three $10 \mathrm{c}$ packets for $25 \mathrm{c}$.

Seven separate colors of $5 \mathrm{c}$ papers for $25 \mathrm{cts}$., postpaid. Giant Dark Purple-Rich and velvety. .................... Pkt., 5c Giant Striped-Large showy flowers, shaded and striped ....................................................................... Pkt., 5c

Giant Violet Blue-A most distinct color, resembling that seen in violets ........................................ Pkt., 5c

Giant Yellow-Yellow, brown blotch on each of the three lower petals...................................................Pkt., 5c Giant Blotehed-Mixed colors ................................... Pkt., 5c Giant Snowflake-Pure white ...................................... Pkt.. 5c Giant Coal Black-Jet black Pkt., 5c

Cassiers-Nixed colors, five-blotched, showy and rich..Pkt., 10c Odier--Mixed colors .................................................... Pkt., 10c

Giant Parisian-Very large, mixed colors.................. Pkt., 10c Giant Trimardeau-Size enormous. Mixed colors....Pkt., 10c

\section{POPPIES.}

For years a great garden favorite; nothing more graceful, the gorgeous flowers bnrsting with fullness, glowing with color; in size, resembling great Peonies or Snowballs. Easy of culture; sow early in spring Many bright and exquisite colors; foliage fern-like.

New Shirley-Beautiful tissue-paper-like in appearance, wonderfully light and bright, mostly double and semi-double when grown in quantities. Colors range from purest white through all shades of pink to vivid scarlet. Some are red with white edges and others veined and streaked from center toward edge; in most delicate and charming confusion. Mixed colors. Pkt., 5c.

Peony-Flowered-Flowers in size and colors equal to Peonies. Pkt., 5c.

White Swan-A new and one of the most effective and valuable Poppies. Plants grow about eighteen inches high, forming a pretty bush crowned with flowers of enormous size, very double and purest snow-white. Pkt., 5c.

Peacock-A vivid scarlet, but the most striking feature of this sort is its conspicuous glossy black zone in the center. Pkt., 5c.

Poppy Carnations (Double)-A very magnificent sort of hardy annuals, about two feet in height. Large globular flowers, often a foot in circumference, of the greatest variety of hues; often a foot in circumference, of the greatest variety
Petals are finely cut and fringed. Mixed. Pkt., $5 \mathrm{c}$.

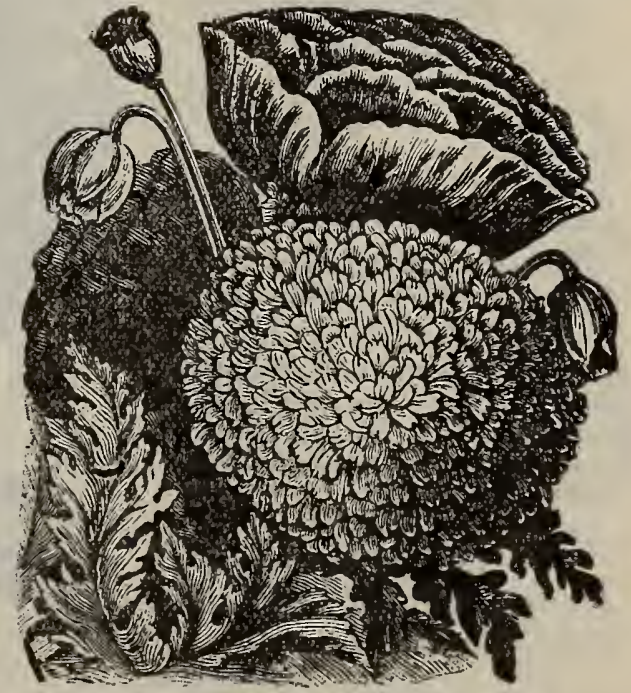

Carnation Poppies. 


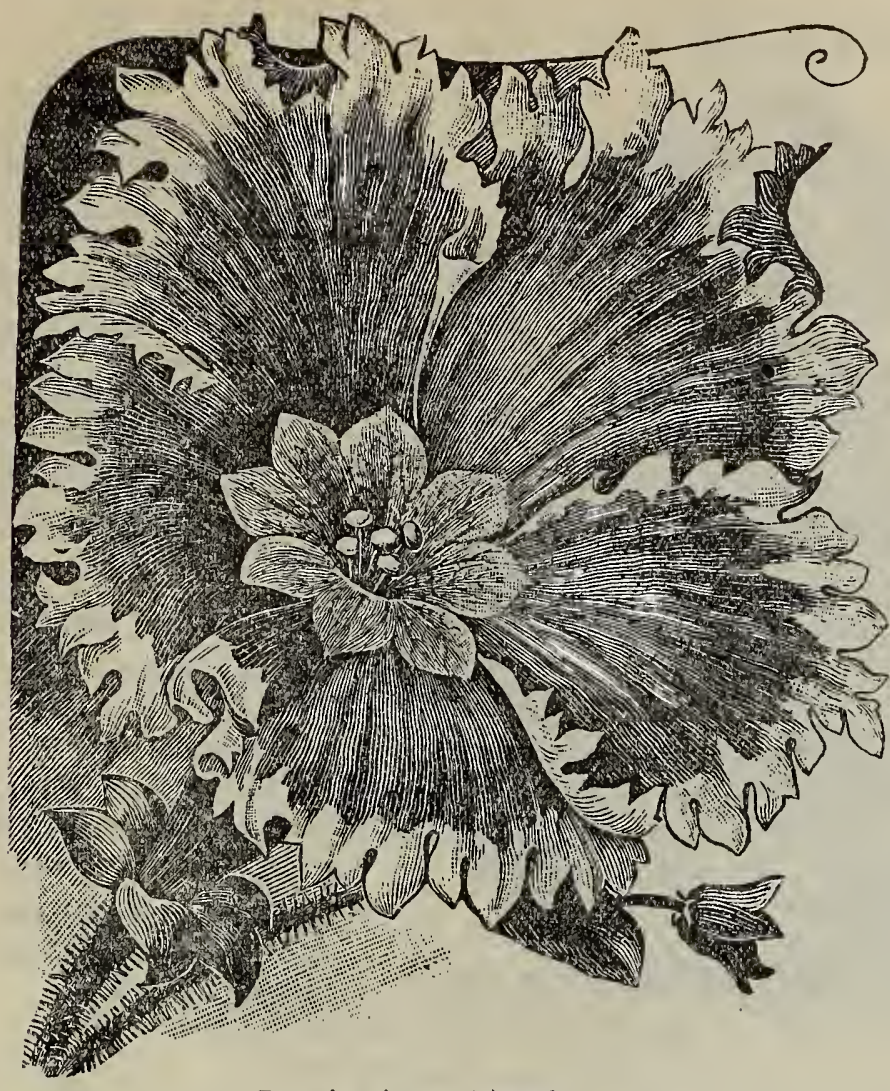

Portulacca (or Rose Moss)-Fine for bordering walks, rock-work or bedding; does not like deep shade or damp soil, but thrives in any other situation, carpeting the ground with foliage, which during the fore part of the day is almost hidden by gay blooms of every color. Single and double. Pkt., 5c.

Petunia-For out-door decoration or house culture few plants are equal to the Petunia. They commence flowering early and continue through the season. Require rich soil in a sunny situation. Some varieties have a trailing habit; they produce showy flowers in profusion, gleaming in purple and white; although perennials, they flower in a few weeks time from the seed.

Hybrid, mixed, pkt., 5c.

Double Fringed, pkt., 10c.

Stocks (Ten Weeks)-Easily grown, popular, flowers of delicious fragrance; of compact habit, bears many long spikes of closely set, large, double flowers, of a waxy texture; exceedingly sweet; varying in color from pearly white to almost black; attains the greatest perfection when grown in a cool, sheltered situation. Requires rich soil and abundance of water. Pkt., 5c.

Verbena-Start seed early under glass if possible; transplant into open ground; they form luxuriant plants and bloom profusely the first season; very sweet scented. Mixed. Pkt., 5c.

Petunia, Single, Fringed.

Zinnia-A free, robust grower, furnishing an abunbance of 1arge, perfectly formed double flowers, which are varied in brilliant colors. Pkt., 5c.

Salvia-Plants grow into very compact bushes and produce long spikes of brilliant scarlet flowers; it is perennial, but flowers the first season from the seed. As a plant along drives nothing makes a more striking appearance. Stands both heat and drouth remarkably well. Plkt.. 5c.

Scabiosa-This is one of the very best bouquet flowers; fine also for clumps or masses in the flower garden; each plant bears a profusion of beautiful, rich and velvety flowers. The long, wiry stems make them especially useful as cut flowers. Sow seed early in the open ground. Hardy, free bloomers. Mixed colors. Pkt., 5c.

\section{TAGETES, OR MARI- GOLD.}

Often called Indian Pink. An old time favorite, but of late years great ly improved; the foliage is always green and handsome, a very profuse green and handsome, a very profuse rich golden yellow and brown, very rich golden yellow and brow

Double Afican-Mixed; large and very double, yellow and orange shades. Pkt., 5c.

Dwarf-Mixed; compact, bushy plants, growing about one foot high, with small, double flowers. Mixed colors. Plkt., 5c.

Try our prize mixture packet of 200 seeds, 10 cts., postpaid.

FULL, HONEST PACKETS,

ALL CROP OF 1900.

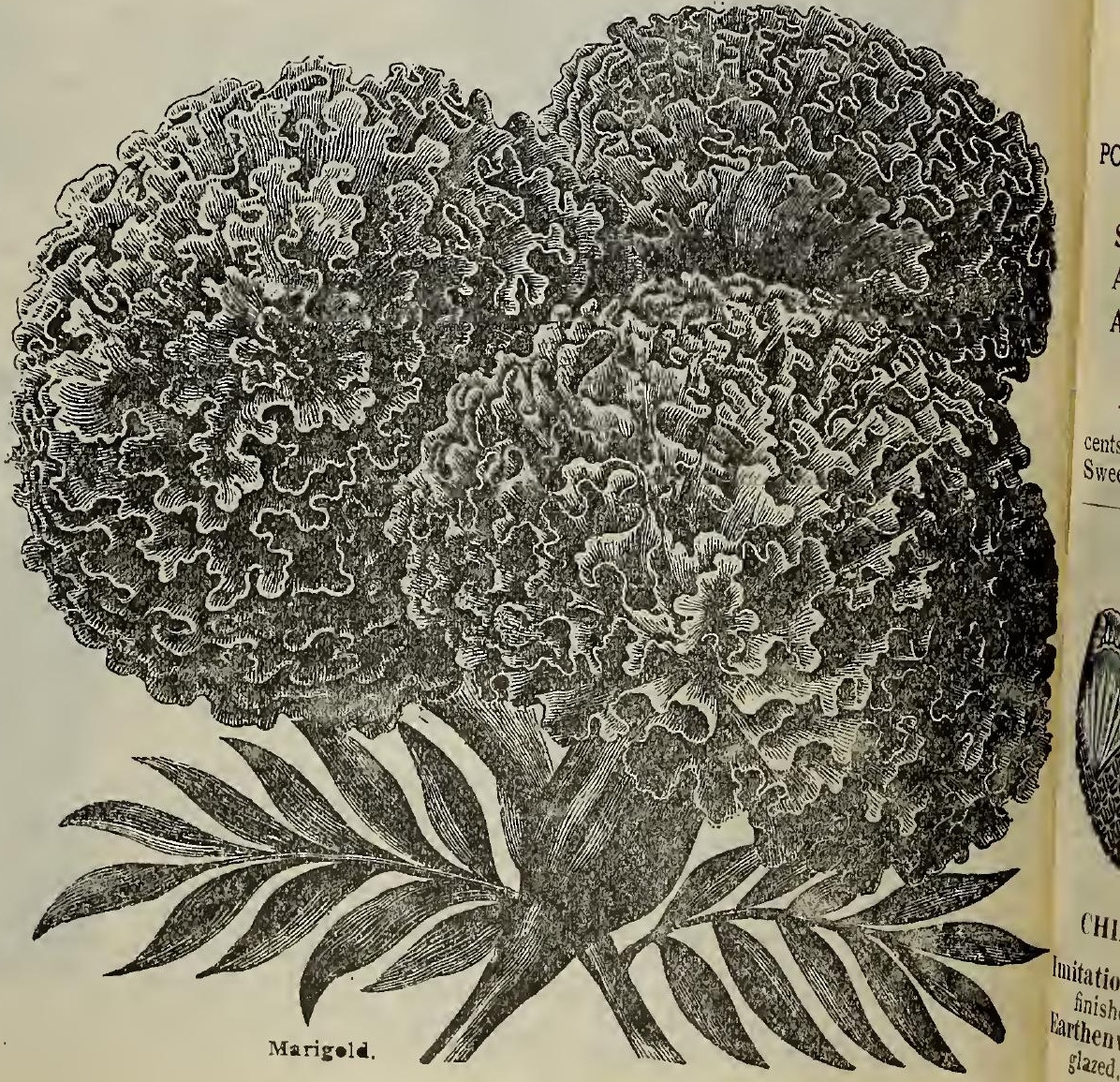




\section{SWEET PEAS.}

For years the Sweet Pea has been Queen of the Garden; delicious in perfume. delicate but exquisite in coloring; profuse in flower, unequaled for cutting; it grows from four to six feet high. Sow the seed rery early. so that the roots will get well established before warm weather. Water freely; cut the bloo seeding; by so doing you will get a greater quantity of flowers.

Adonis-Rose and carmine.

Alba Magnificia-Pure delicate white.

Apple Blossom-Bright rose and pink.

Alice Eckford-Rich creamy white, purplish wings.

America-White ground, striped with bright red.

Blanche Burpee-Large pure white.

Blanche Ferry-Deep rosy red, blush white wings.

Blushing Beauty-A distinct soft pink.

Boreatton-Very dark maroon.

Countess of Radnol-Pure light 1arender.

Celestial-Delicate larender blue, wings silvery lavender.

Countess of Aberdeen-Sott pink.

Dorothy Tennant-Deep rosy mauve.

Emily Eckford-Rosy heliotrope, wings bluish.

Emily Henderson-Large, snow-white.

Emily Lynch-Pink aud white.

Firefly-Rich crimson scarlet.

Gaiety-Bright crimson, striped.

Golden Gleam-Bright yellow.

Her Majesty-Clear rosy carmine.

Ignea-Rich scarlet crimson.

Indigo King-Lorely dark maroon.

Juanita-White, lavender striped.

Katherine Tracy--Exquisite bright pink.

Lottie Eckford-White edged with blue.

Orange Prince--Orange salmon, wings pink.

Mrs. Gladstone--Bright soft pink.

Monarch--Maroon purple, wings plum purple.

Mars--Bright fiery crimson.

The Bride-White.

Venus-Soft rosy buff, shaded pink.

LARGE PACKET, ANY VARIETY, ONLY 5c, POSTPAID.

\section{COLLECTION OF SWEET PEAS.}

Selections of any six $5 \mathrm{C}$ packets for $==25 \mathrm{C}$ Any twelve 5c packets for $==\quad=\quad=40 \mathrm{C}$ All Colors, mixed, standard sorts, oz., $==10 \mathrm{C}$

\section{SPECIAL PREMIUM OFFER.}

With erery order for Flower Seeds in packets amounting to seventy-five cents or more, we will mail you free one-fourth pound of our extra fine mixed Sweet Peas.

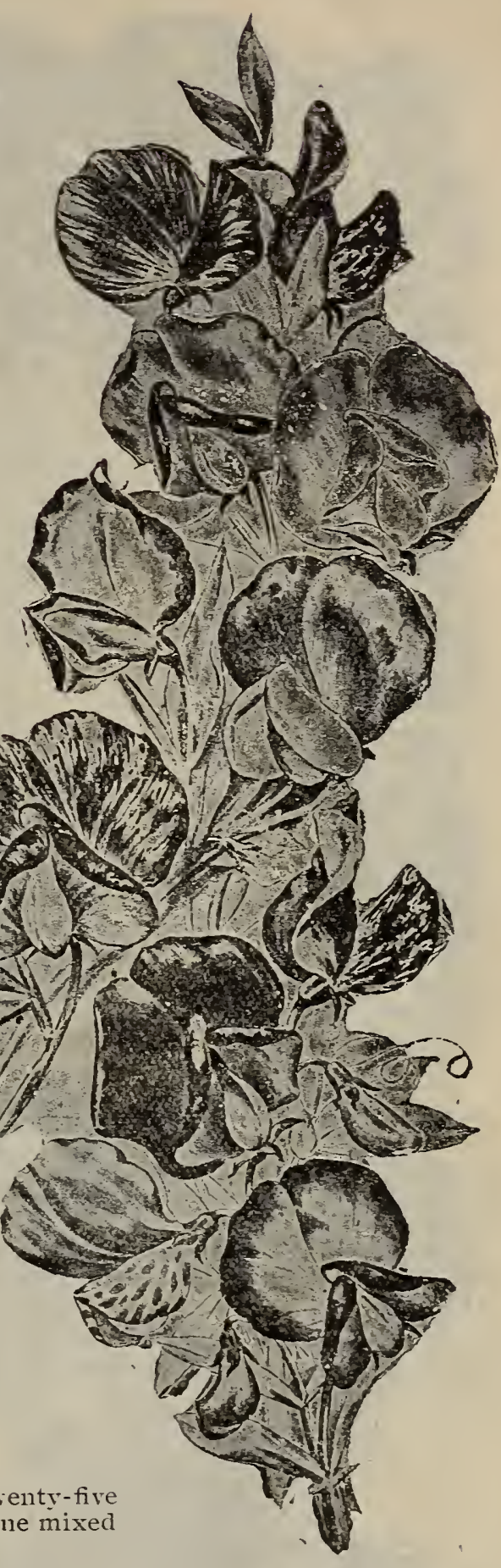

FLOWER POTS, JARDINIERS, ETC.

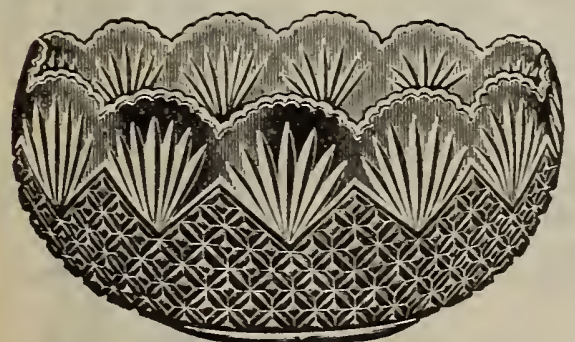

CHINESE LILY BOWLS.

Tot Postpaid.

Imitation Cut Glass. Nicely

finished, each.......................... 20 cts

Earthenware. Handsomely
glazed, each ........................... $15 \mathrm{cts}$

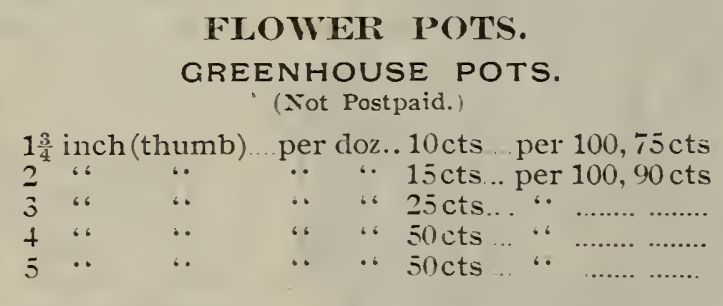

STANDARD POTS AND SAUCERS. (Not Postpaid.)

6 inch (Pots and Saucers) ...............each $10 \mathrm{cts}$

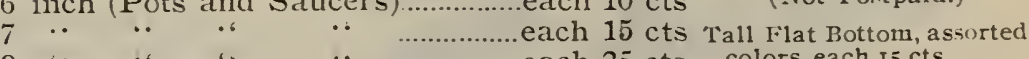

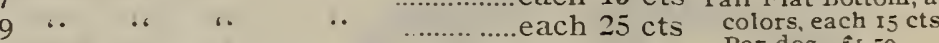
$12 . . \quad \therefore \quad 6 . \quad$. $\quad . \quad \ldots \ldots \ldots \ldots . . .$. each $50 \mathrm{cts}$ Jardiniers From 30c to $\$ 5.00$.

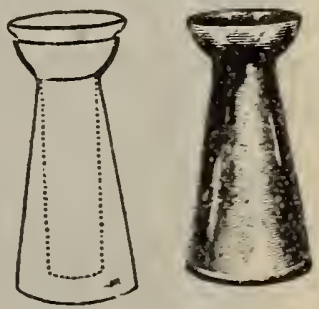

Hracinth Glasses. (xot Potpaid.) Per doz., \$1.50.

Tye Shaped, assorted col urs,each 20 cts.; doz. $51 .-15$ 

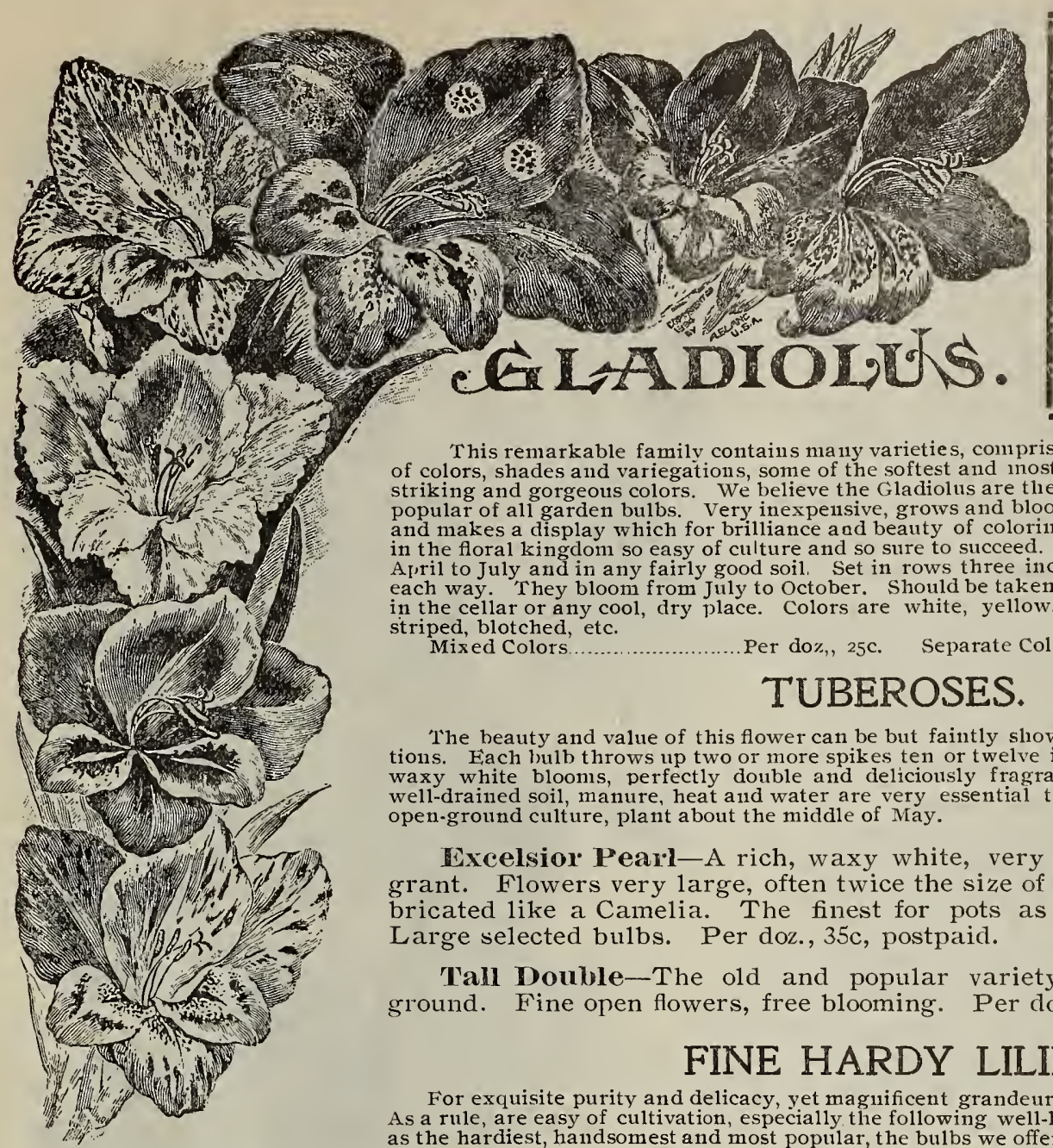

We offer nothing but FIRST SIZE BULBS.

You get the same service by mail that you get at our counter.

Do not forget our SPECIAL OFFER.

One packet each any ten varietics, your own selection, Flower Seed, for 25 cts., postpaid.

This remarkable family contains many varieties, comprising all colors and combinations of colors, shades and variegations, some of the softest and nost delicate hues; again the niost striking and gorgeous colors. We believe the Gladiolus are the most satisfactory, desirable and popular of all garden bulbs. Very inexpensive, grows and blooms rapidly in any soil or climate and makes a display which for brilliance and beauty of coloring is unsurpassed. Nothing else in the floral kingdom so easy of culture and so sure to succeed. May be planted any time from A pril to July and in any fairly good soil Set in rows three inches apart or in beds six inches A ril to in the cellar or any cool, dry place. Colors are white, yellow, pink, scarlet, carnine, violet, striped, blotched, etc.
Mixed Colors...
..Per doz,, 25c. Separate Colors..
..Per doz., $30 \mathrm{c}$.

\section{TUBEROSES.}

The beauty and value of this flower can be but faintly shown either by words or illustra. tions. Each hulb throws up two or more spikes ten or twelve inches high, each bearing pure waxy white blooms, perfectly double and deliciously fragrant. It delights in a strong, rich, well-drained soil, manure, heat and water are very essential to its perfect development. For open-ground culture, plant about the middle of May.

Excelsior Pearl-A rich, waxy white, very double, delightfully fragrant. Flowers very large, often twice the size of the ordinary sort, and imbricated like a Camelia. The finest for pots as well as for the garden. Large selected bulbs. Per doz., 35c, postpaid.

Tall Double-The old and popular variety; splendid for the open ground. Fine open flowers, free blooming. Per doz., 30c; postpaid.

\section{FINE HARDY LILIES.}

For exquisite purity and delicacy, yet magnificent grandeur, we would recommend the Lily. As a rule, are easy of cultivation, especially the following well-known sorts. Carefully selected as the hardiest, handsomest and most popular, the bulbs we offer are large, healthy and vigorous.

Auratum-The golden-banded Lily of Japan; immense white flowers beautifully spotted with crimson. Extra fine bulbs, 25c each, postpaid.

Album (Speciosum)--Pure white, with beautiful recurved petals; very fragrant; large flowers and very showy. Large bulbs, 25c each, postpaid.

Lemon Lily--A beautiful Lily, with upright, perfect star-shaped flowers of pure yellow; fine and attractive. Extra bulbs, 10c each, postpaid.

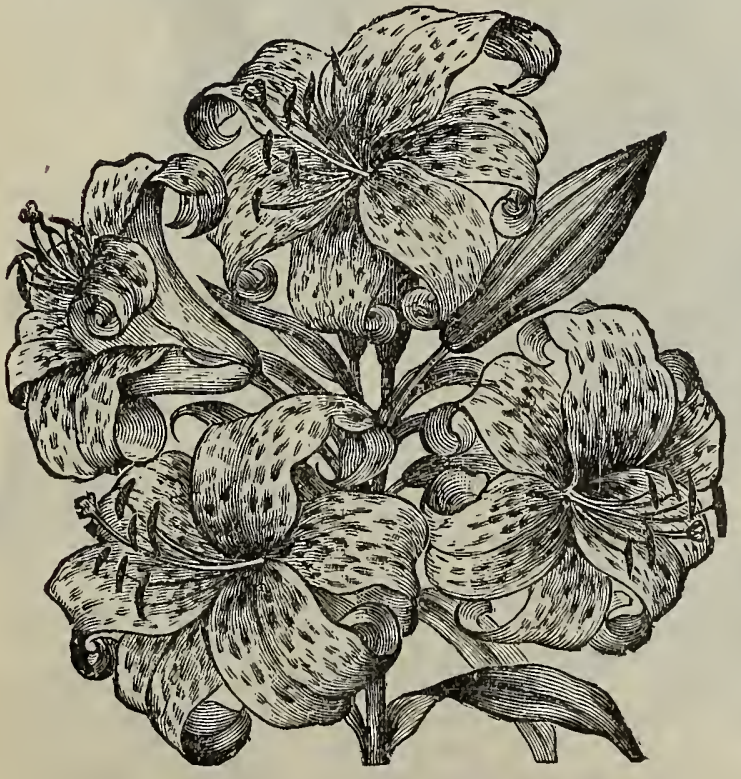

Auratum
Rubrum (Criunson-Banderl)..Flowers are white with a deep rosy or crimson band on each petal, with deeper colored spots between; often five or six inches in diameter; very fragrant and hardy. Fine bulbs, 25c each, postpaid.

Tigrinium (Improved 'Tiger Lilly) --Orange salmon, spotted black; very hardy. Large bulbs, $10 \mathrm{c}$ each, postpaid.

Use our Land Plas= ter for your Lawn, and use it early.

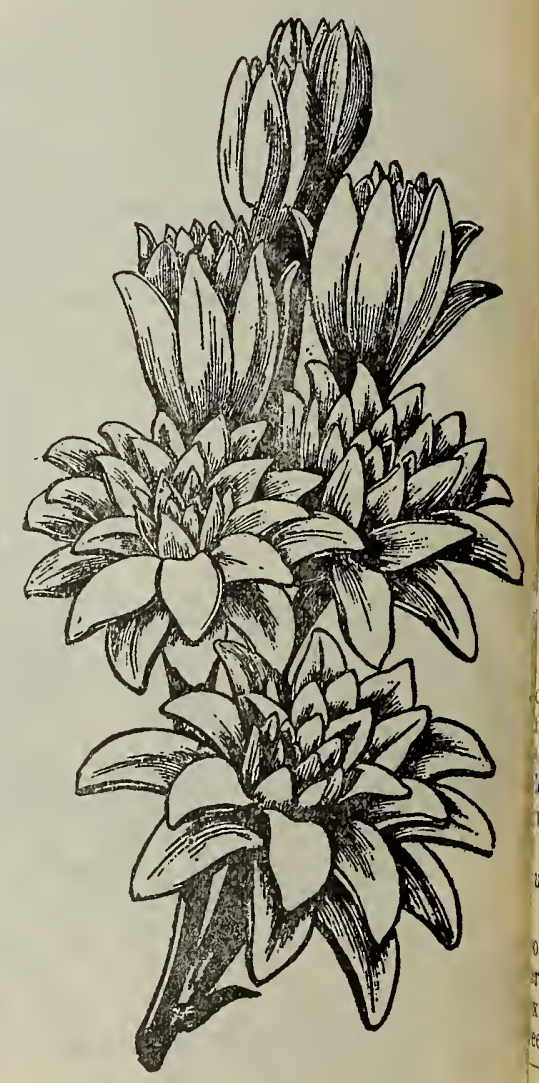

Tuberoses. 


\section{CALLAS.}

California Giant White--Very popular and easily grown. Large bulbs, 20c each, postpaid.

Black Calla-Large fowers. color a clear jet black, a striking oddity. Large bulbs, 15c each. postpaid.

\section{LILY OF THE VALLEY.}

Lily of the Valler-A bed of Lilies of the Valley is one of the most attractive und delightful spots in any garden. It flourishes with little care and gires great abundance of bloom. Beautiful, lovely and fragrant bell-shaped flowers; perfectly hardy, and, when once established, will last for years. Pips, 5c each; per doz., 50c. Extra large clumps, 50c each. postpaid.

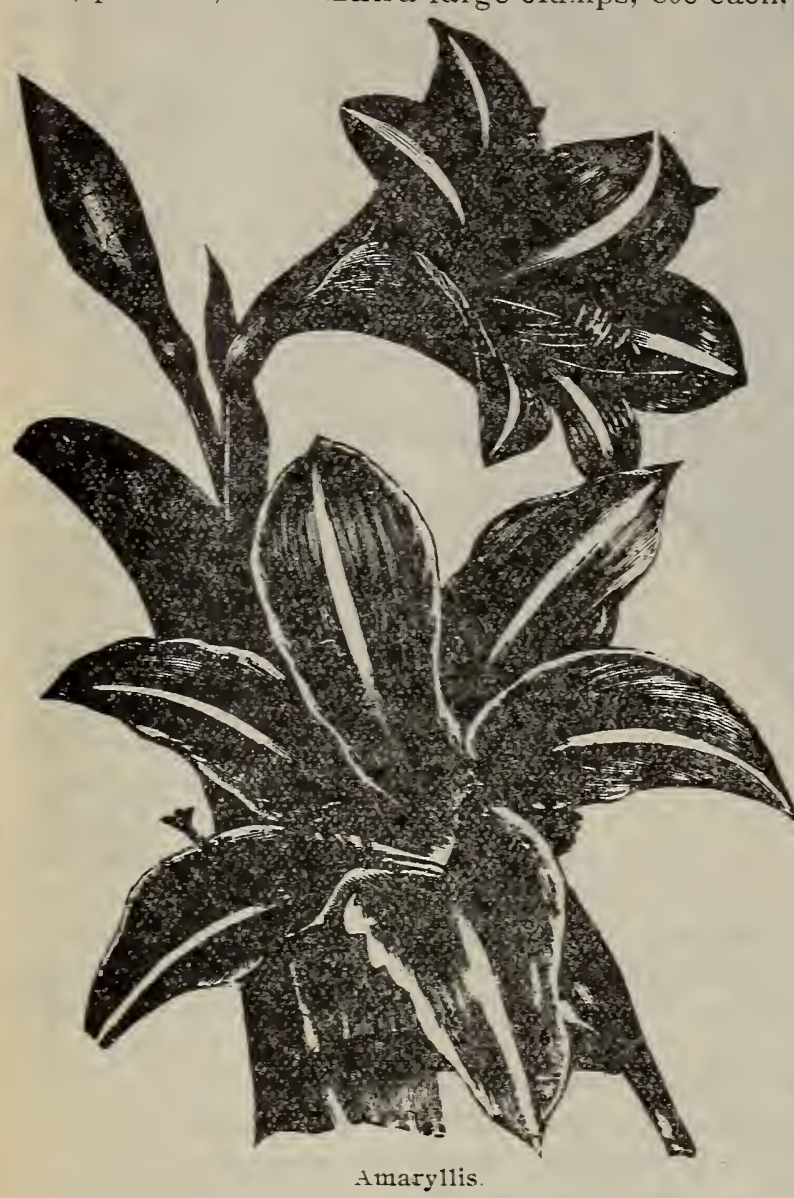

BEGONIAS.

Tuberous-Rooted-A very handsome foliage plant; also bears a nerer-ending profusion of rery beautiful flowers; of recent years hare been brought to great perfection. They make splendid beds in the garden, but should be protected somewhat from the hot sun. With the coming of cold weather should be taken up and packed in soil away from the frost. The enormous size and intense brilliancy of the flowers astonish those who hare never seen any but the ordinary house Begonia. They embrace erery shade $\hat{~ o f ~ p u r e ~ w h i t e, ~ r o s e, ~ s c a r l e t ~ a n d ~ o r a n g e . ~ V e r y ~ l a r g e . ~}$ Bulbs can be started from March to June. Single mixed, all colors, 10c, postpaid; per doz.. $\$ 1.00$, postpaid.

Crinum Kirkii-This magnificent variety produces flowers of the greatest beauty. Usually two flower stalks of dark purplish color are sent up at the S same time, each bearing a large umbel composed of a fozen lily-like flowers of wondrous beauty and fragrance. The petals are broad and pure white, with a deep purple stripe through the center. Extra large bulbs, $65 \mathrm{c}$ each, postpaid.

Tigridias-The most showy of all the summerflowering bulbs; growing about three feet high, with large, wide-open, triangular-shaped blooms four to six inches across. Colors and markings very odd and attractire, exquisitely spotted; they flower rery freely throughout the summer. Large bulbs, $5 \mathrm{c}$ each; per doz., $45 \mathrm{c}$, postpaid.
AMARYLLIS.

This family of bulbs has large umbels of magnificent lily-like flowers of the richest coloring and often rery large: besides pure white and a soft pink shades, many are of intense crimson, scarlet. orange: some are striped. Can be kept in pots the year round or planted out in the open ground during the summer. For large blossoms should alternate rest and growth; while growing give them plenty of sun and moisture, but while at rest little or no water.

Belladonna Major-Elegant silvery white flowers tipped with rose; of great fragrance and

Equestre-A magnificent sort of scarlet color, throat snow white. Fine bulbs, $20 \mathrm{c}$ each, postpaid.

Johnsonaii-A grand old sort; flowers large and very beautiful, deep, dark red striped with white. Extra fine bulbs, $40 \mathrm{c}$ each, postpaid.

Formosissima-Cf a deep, rich, velrety crimson intensely brilliant. A free bloomer and succeeds well either in pots or the open ground and blooms soon after planting. Few flowers equal it in richness and beauty. Very large bulbs, $15 \mathrm{c}$ each, postpaid.

Peonies-Luxurious foliage plants, with magnificent double incurved flowers of enormous size. deliciously fragrant. Some are rery rich dark scarlet. others white, some very soft and delicate in color: many rarieties and shades. Each, 20c; postpaid, $25 \mathrm{c}$.

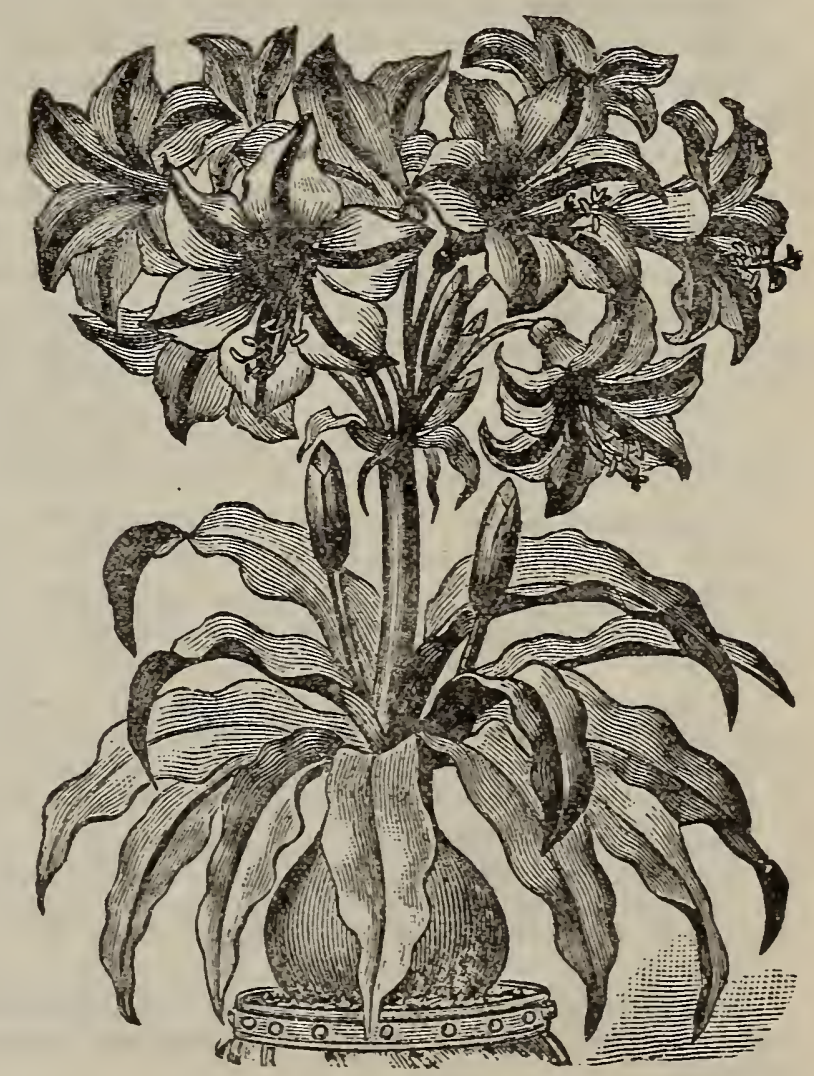

rinum Kirkii.

$$
\text { d. }
$$

Write for Catalogue. beauty. Large bulbs, $20 \mathrm{c}$ each, postpaid. 


\section{DAHLIAS.}

Set them out the last of $\mathrm{May}$ in deep rich soil and cover almost three inches. Will bloom in August. Dahlias are becoming great fayorites everywhere and we cannot recommend them too highly. We know of nothing more showy for table decoration than a well-arranged bouquet of long-stemmed Cactus and other Dahlias.

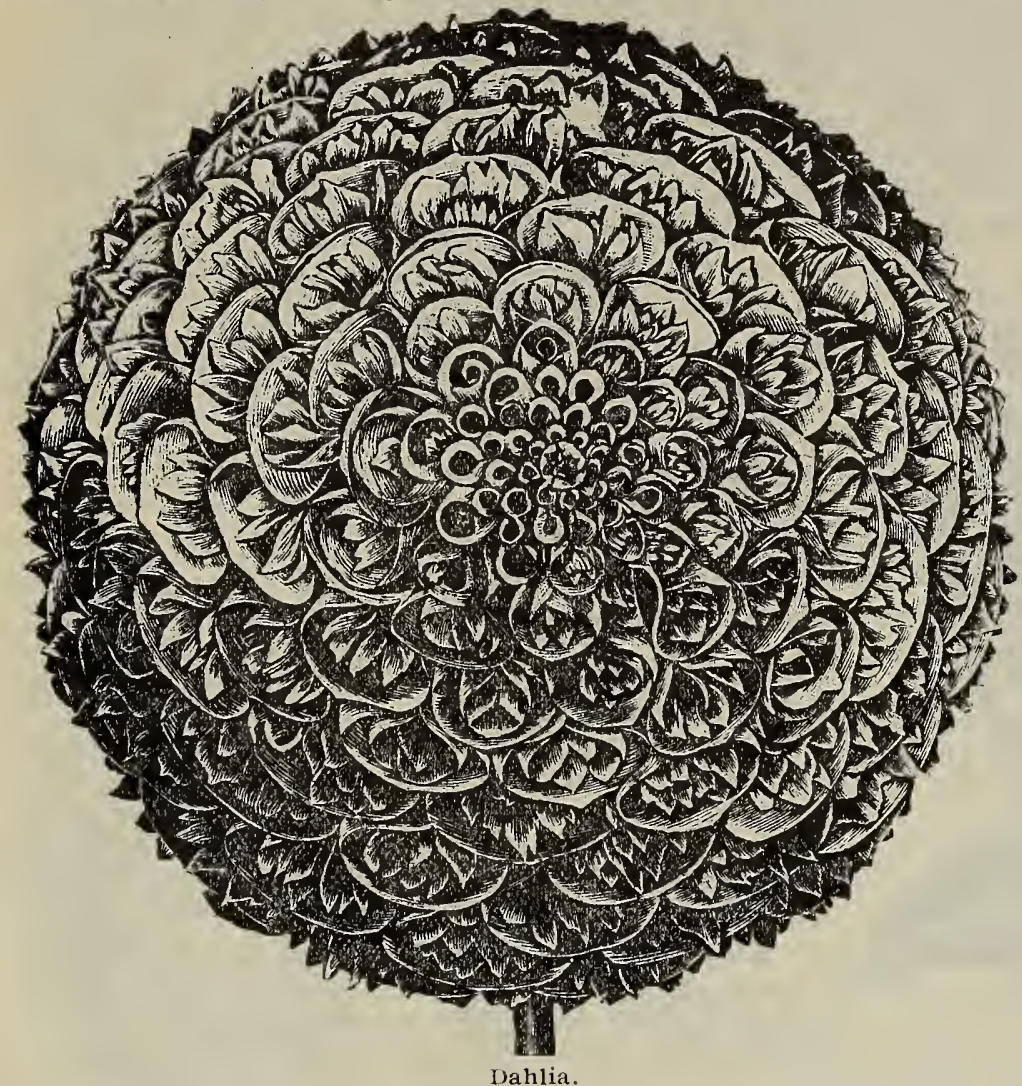

Cactus Dahlias-Large, broadpetaled flowers; most highly prized for decorative purposes. Each, 25c, postpaid.

Pompon, or Bouquet-Flowers rather small, borne on long stems, elerant for pot plants or out-door culture. Each, 25c, postpaid.

Double-Flowered-Flowers large and globe-shaped, close-petaled, rich in color; plants rather tall. Each, 25c, postpaid.

Single-Flowering-By many preferred to the double varieties. Very early and constant in bloom. Flowers large, any color from white to darkest maroon. Each, 25c. postpaid.

\section{Hardy Climbers.}

\section{Clematis, Queen of the Climbers}

For small trellises or piazza pillars nothing can compare with the clematis vine. It is a very rapid grower, often reaching the height of fifteen feet during the season. Used often to cover ret durk stumps, etc. Foliage neat, habit

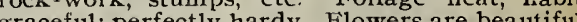
gracelul; perfecty hardy. Flowers are beautiful Jume and dil June and deep enough so that the crown of the face. We have three to five-year-old roots only.

\section{LARGE-FLOWERING SORTS.}

Jackmanii-Flowers a rich, royal purple, the best known. 50c each, postpaid.

Madiame Baron Viellard-Light rose with lilac shadings, very distinct. Each, 60c, postpaid.

Miss Bateman-Pure white with chocolate anthers; commences to bloom very early. Each, 60c, postpaid. Gypsy Queen-A rich dark velvety purple, rank grower and a free bloomer. Very attractive variety. Each, 60c, postpaid.

Henryi--Flowers eight-sepaled, pure white and very large. Each, 60c, postpaid.

FRAGRANT AND SMALL-FLOWERED SORTS.

Crispa-A fine deep blue with a whiteborder, deliciously fragrant. Each 30c, postpaid.

Flammula-Pure white, blooms in clusters, fragrant. Each $30 \mathrm{c}$, postpaid.

Paniculata-A vine of very rapid growth, quickly covering trellises and arbors with handsome glossy green foliage. Flowers are medium size, pure white, and of most delicious and penetrating fragrance. Very hardy. One of the very choicest varieties. 30c, postpaid.

Madeira Vine-The old favorite Climbing Mignonette; tuberous rooted, rapid grower, thick, glossy leaves and hanging stems covered with flowers; white and very fragrant. Does best in a warm, sunny, sheltered location. Large roots, 2 for $25 \mathrm{c}$, postpaid.

Cinmamon Vine-Beautiful summer climber; glossy foliage and fragrant flowers. The stem dies down in winter, but the root is hardy. Each $10 \mathrm{c}, 3$ for $25 \mathrm{c}$, postpaid.

Gloxinia-One of the most handsome summer-blooming plants, the rich and varied colors of the flowers being beautiful in the extreme; some speckled, others crimson, violet, rose, white, etc. Flowers three inches long by two inches in diameter; upright and pendulous. 15c each, postpaid.

Hyacinthus Candicans-A species of Hyacinth, blooms during August and September. Grows from three to five feet high with spikes of pure white flowers, bell-shaped and pendulous. The bulb is $W$. The large and throws up strong flower stems; very hardy and grows stronger each year. For the cemetery nothing can be more beautiful or appropriate. Will thrive in any situation. 2 for $15 \mathrm{c}$, postpaid.

Caladium (or Elephant's Ear)-One of the most effective plants in cultivation for planting upon the lawn. Grows often five feet high with handsome leaves three feet long. Will grow in any garden soil, of easy culture; should be packed in sand during the winter in a warm, dry cellar. 20c each, postpaid. Mammoth size bulbs, 40c each, postpaid.

NOTE $==$ We offer this year a line of pot=grown Dahlias selected from fine named sorts and some especially fine separate colors. We offer these plants at io cts. each; $\$ 1.00$ per doz., prepaid, mail or express.

Try Armour's Food for Flowers; per 1b., 25 cts.; not prepaid; postpaid, 30 cts. per $1 \mathrm{~b}$. PE $-W$ Put up in one-half and one pound packages, handsomely lithographed, with full direction for use. A thoroughly concentrated fertilizer. 


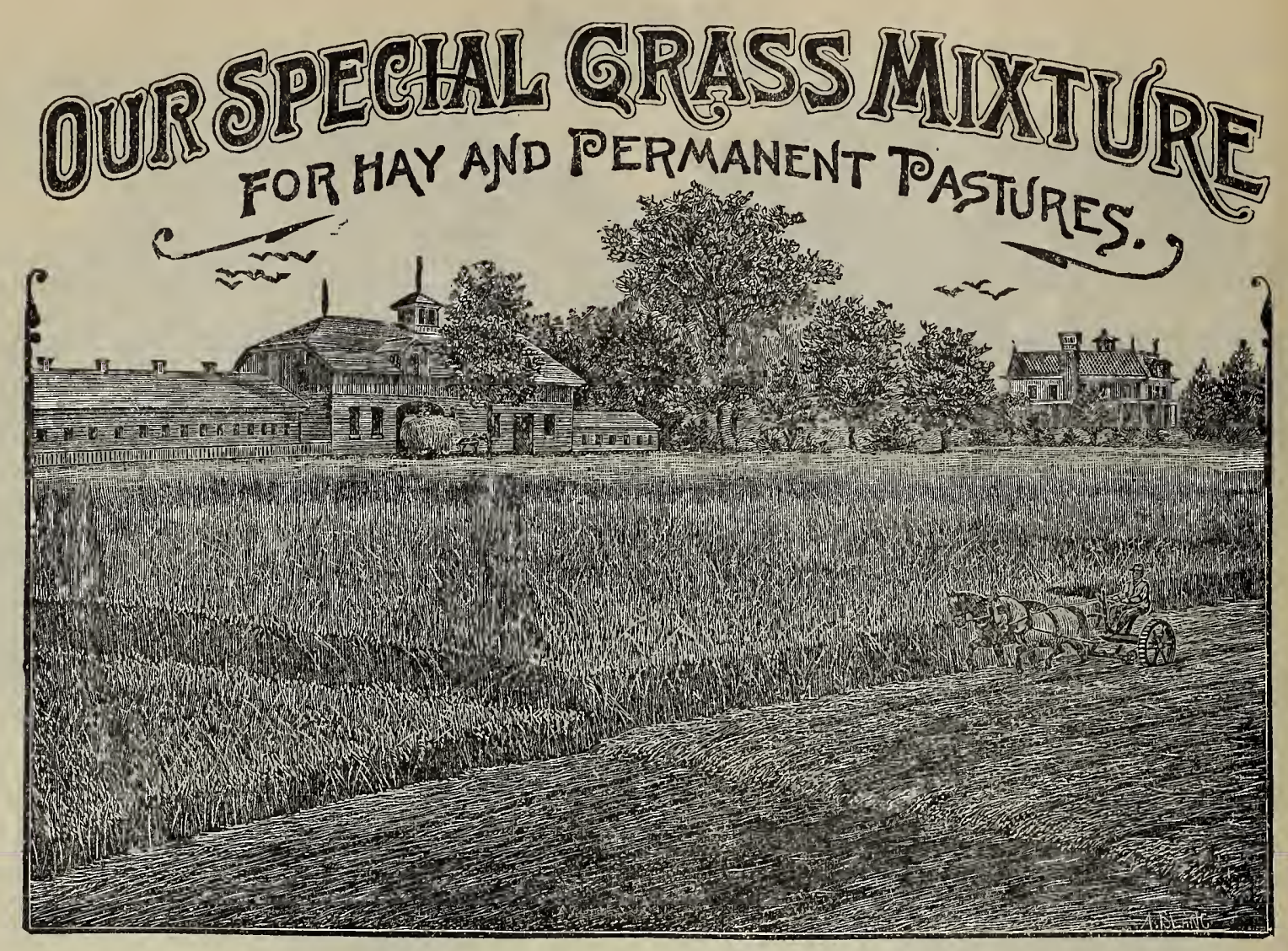

"As ye sow, so shall ye reap.",

In this portion of our catalogue we wish to call your especial attention to the fact that we are in position to offer this year Field and Grass Seeds that are of a very superior quality. We have at large expense put in a very complete and expensive cleaning machine, which enables us to offer carefully recleaned seeds that will give you perfect satisfaction. We also request that you notice, particularly, our special grass mixture for hay and permanent pasture, and also our woods pasture mixture, which is very necessary to Southern Missouri and Arkansas.

\section{Our Special Grass Mixture for Good Clean Open Ground.}

We have demonstrated during the season just past that this mixture is a winner. We are making this mixture by blending good, hardy, rank growing grasses with a view to making a fine hay crop as well as an excellent pasture. We find that, with very few exceptions, our patrons are having excellent success with our mixed grasses. We also find that in the few cases where they are not meeting with success, the fault lies with them, not with us, and is directly due to the fact that some few are entirely too sparing with their seed, trying to make one bushel do the work of five. We would much prefer to sell you one bushel for one acre than to sell you ten bushels for twenty or thirty acres. We would rather you were satisfied with one acre, than to have you sow twenty, be dissatisfied, and tell your neighbor without giving him the reason. Try anywhere from one to four acres of this mixture if you have suitable 1and. If you have not the right kind of soil, let us know what kind you have. And we will put up a special mixture suitable to your land. We solicit correspondence from parties using our mixed grasses, and are always glad to pay any postage that might accrue. Sow one bushel to the acre. Price per bushel of twenty pounds, $\$ 2.75$.

\section{Woods Pasture Mixture.}

For good timber land or Orchards, which we know will give you good results; will stand on grood 1 and for five or six years without the necessity of renewing. We have prepared this mixture with a view to give you an early and late pasture by blending grasses best adapted for woods pasture with a good ad-a dition of clovers. We know that with good strong seeding you cannot fail. We saw, this season, five tons of excellent hay cut from one acre of this mixture which had not been pastured, and in two weeks from time of cutting was ready for grazing, and remained so throughout the season. Sow one bushel to the acre, Price per bushel of 20 pounds, $\$ 2.25$.

Merchants not receiving our Wholesale Price Card of Field Seeds, Grass Seeds, Sweet Potatoes, Onion Sets, etc., are requested to write for same. We give you prompt service and save you freight. 


\section{Woods Pasture Mixture.}

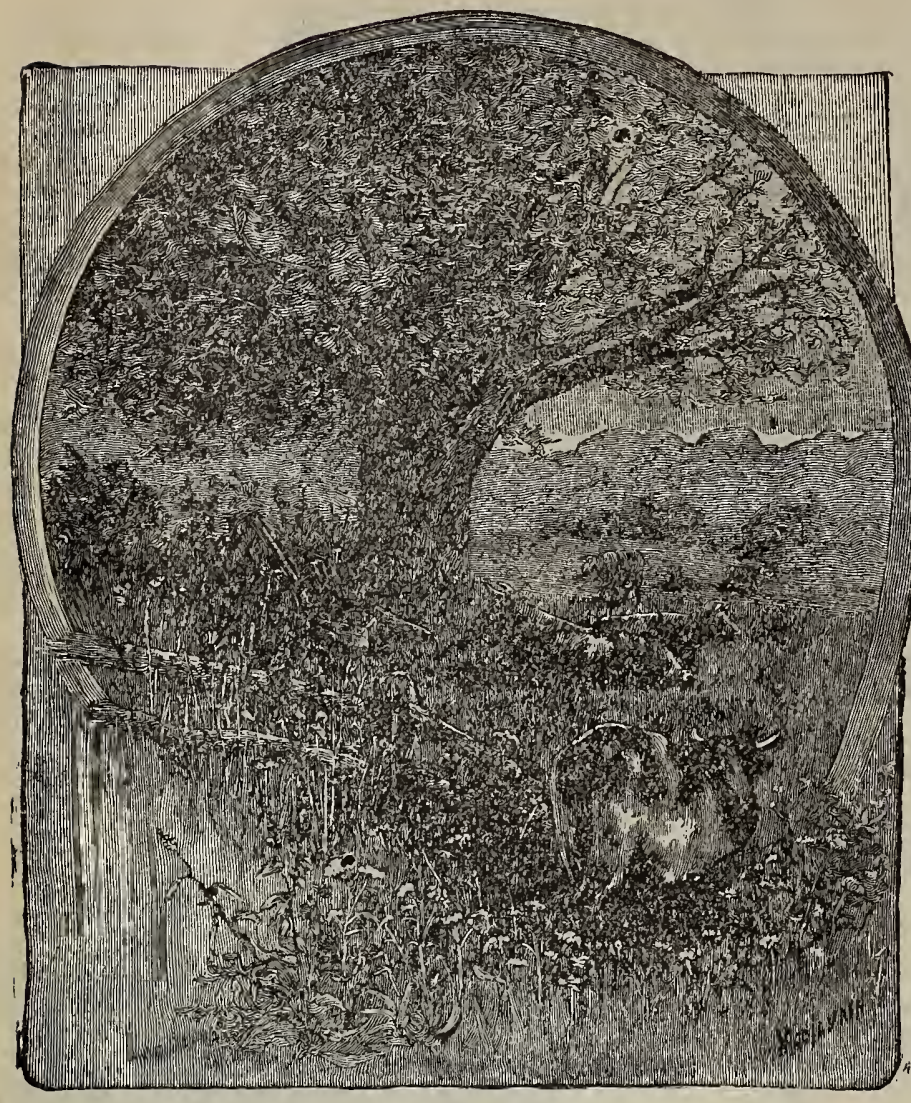

Our Woods Pasture Mixture.
For Top Seeding.

You should seed your timber land. Our special mixture for rough timber land, comprised of grasses that are especially good for top seeding, and mixed with a view to giving you a good pasture on your high timber cround, no matter how dry the season. In preparing this mixture we have not only considered your cattle and horses, but have remembered your hogs and sheep, and have made a special study of the wants of our friends in South Missouri and Northern Arkansas. Sow one and one-half bushel to the acre. Try five or ten acres this year, and see if we are right. Price per bushel of twenty pounds, $75 \mathrm{cts}$.

Most of our grasses are Kentucky grown. By handling all this stock in car lots, and by carefully recleaning over our own mills, we are able to offer you pure seeds and at the same time make a great saving in prices to our customers.

\section{LIKE PRODUCES LIKE-GOOD SEED, GOOD RESULTS.}

We are Spring field agents for Planet Jr. Garden Tools. Write for catalogue.

\section{Meadow Fescue, or English Blue Grass.}

One of the grasses most used in permanent or temporary meadows. It succeeds best in moist, light soil in well drained meadows and in low valley land. It should not be grown in dry soil. After being mowed it grows again very quickly; for forage. either green or dry, is very nourishing and much relished by cattle, especially when it has been cut young. It is a very valuable grass in this section. Height about two feet. 20 pounds to the bushel. Sow two bushels to the acre. Price on application.

\section{Orchard Grass.}

Too much cannot be said of Orchard Grass. Stands the drouth well and grows vigorously in our climate, and thrives well in poor soil. Never before has Orchard Grass been used so extensively in this vicinity as it has in the past two years. Excellent for hay and permanent pasture. Sow two bushels to the acre, 14 pounds to the bushel. This is our special, recleaned, highgrade seed. Price on application.

\section{Our New Location.}

In submitting this portion of our 1901 Catalogue, we wish to call the attention of our friends and patrons, especially in our immediate vicinity, to our new location, in which we will have much improved facilities for handling our large and growing trade. Also to the fact that we have, at great expense, put in very complete and extensive cleaning machinery. The field and grass seeds we now offer to the trade will be thoroughly re-cleaned, a fact which the farmers in our vicinity, especially, will appreciate, as they know how disastrous it is to load their flelds with foreign and noxious weed seeds.

Springfield now has as complete a Seed Store as can be found in any of the larger cities.

We cordially invite our friends to call and inspect our new quarters.

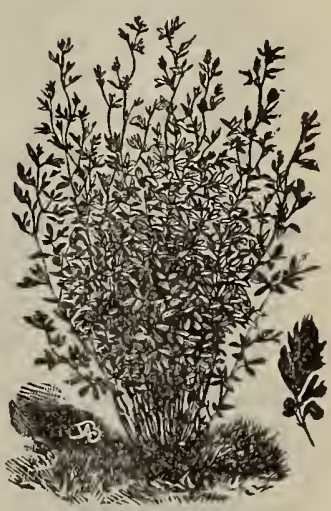

Orchard Grass.

WE OFFER YOU NO UNTRIED NOVELTIES, BUT RELIABLE, STANDARD VARIETIES, AND ARE CONFIDENT THAT WHAT YOU BUY FRON US WILL PLEASE YOU. 


\section{ITALIAN RYE GRASS.}

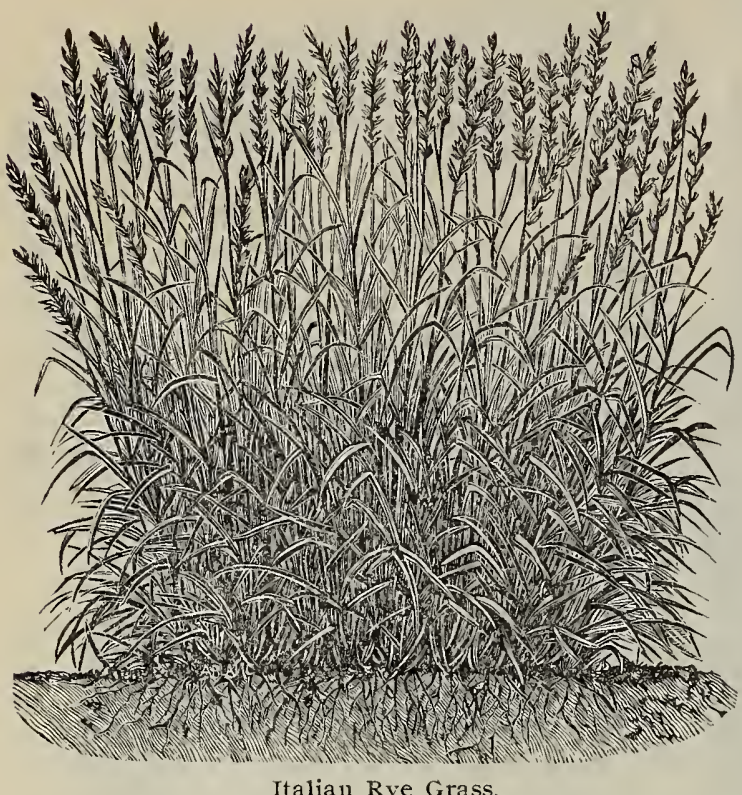

A very valuable grass for a quick and abundant pasture. A remarkable grower, and in addition has advantage of standing extremes of temperature; remains green throughout the winter, and retains its freshness in the hottest summer months. Its exceeding productiveness also makes it very valuable for a hay crop. It yields an abundant cutting in four or five weeks after sowing, and every six, weeks after that until fall. Farmers, if you want roughness and a big yield, this is the grass. Our stock is positively pure and carefully re-cleaned. Height from one and a half to two and a half feet; forty pounds to the acre. Prices on application.

On account of market fluctuations, it is impossible to make close prices in this catalogue on Field and Grass Seed, good for any length of time. Therefore, prefer to make prices on application. We have built up our present large trade by saving our friends money. If you will send us an estimate of your wants, will make you very close figures.

Mixed Lawn Grass-If you intend using Lawn Grass do not fail to see description of our own select mixture on page 63, which has given such general satisfaction, and which is sure to give good results.

\section{FANCY KENTUCKY BLUE GRASS.}

(Our stock is pure Kentucky Grown.)

One of the most widely distributed and valuable natural grasses. It is a true perennial, 1asting indefinitely and improving every year. It forms a close turf, starts very early in the spring and lasts until frost. It succeeds in almost any soil, dry, rocky, sandy or gravelly. It takes, however, two or three years to become well established. Height, nine to eighteen inches. 14 pounds to the bushel, two bushels to the acre. Prices on application.

Kentucky Blue Grass, Extra Clean-A second grade in the chaff, therefore should be sown much thicker than Fancy. 14 pounds to the bushel. Price on application.

Bermuda Grass-A most vaíuable grass especially for lawn. It is of a dwari habit with long creeping stems, rooting at the joints and covering the ground with a matting of fine turf, which no amount of tramping will impair. It is also useful for binding drifting sand, or steep embankments subject to wash. When once established it will make a permanent lawn. It thrives in the poorest soil and resists extreme drouth and most intense heat. Price per poumd, $\$ 1.00$

Fancy Red Top (Herds Grass) - A very hardy native perennial grass. Succeeds best in moist land. It accommodates itself to a variety of soils, however, even to quite dry situations, and stands our hot climate admirably. It is, perhaps, the most perennial grass we have, and it enters largely into the composition of our best natural pasture, and remains green for the largest part of the year. We can now offer this stock, CLEAN FROM CHAFF, which is absolutely pure. The weight of fourteen pounds to the bushel is based on Red Top in the chaff. It would take almost double the amount of this superior seed to make a measured bushel. Sow 14 pounds to the acre. Prices on application. Write for samples.

Ordinary Red Top, or Red Top in the Chaf-For description see Fancy Red Top. This seed is considerably cheaper than the clean from chaff. 14 pounds to the bushel; sow two and one-half bushels to the acre. Prices on application.

Renember our Perennial Pasture Mixture, which is especially adapted to this section. We make this mixture after much experimenting with natural and imported grasses. And after having tried it carefuly, we stake onr reputation on it. Farmers, if you want something really good, try our permanent Pasture Mixture.

Barley, Champion-An early and proific variety. to pounds to the bushel; sow vine and one-half bushels to the acre. Price on application.

Buckwheat, Silver-Hull-A good variety for flour. Remains in bloom longer than the Common; the flour is whiter and more nutritious; also good for bees. 48 pounds to the bushel; one-half bushel to the acre. Price on application.

Buckwheat, Japanese-Enormously productive. The grains are much larger than any other sort. From one-half bushel sown, a crop of forty Bushels has been harvested. It ripens a week earlier than Silver-Hull. 48 pounds to the bushel. Sow one-half bushel to the acre. Price on application.

Buckwheat, Common-An old standard sort.

Write for prices on Bone and Cotton Seed Meai for fertilizers. Flax Seed Meal for stock. 


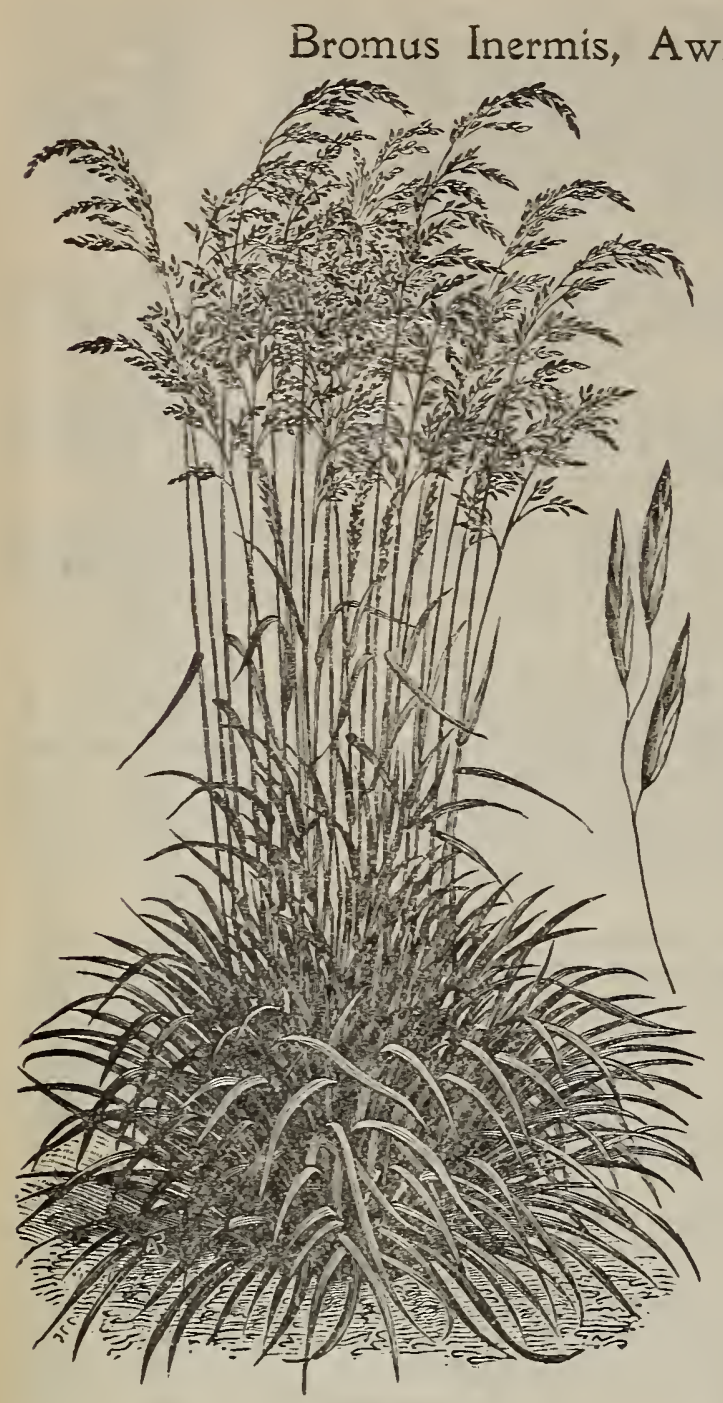

Too much camnot be said of this hardy perennial grass. So extensively has Bromus Inermis been spoken of by farmers who have tried it, that we hardly think it necessary to go into an extended description, but would say for the benefit of those who hare not used it, that it is rery hardy and will stand greater extreme of heat, cold or drouth, and yield a larger crop of pasture or hay than any grass known. All kinds of stock eat it greedily and the analysis show it has exceedingly rich and flesh-forming ingredients. A ferv years ago it was comparatively unknown, but has now taken its place among the standard grasses.

If you would keep up with the times you should at least try Bromus Inermis. The seed should be sown in the early spring. Trienty pounds required to seed an acre. Tre have a rather limited supply of this raluable seed, but while it lasts we offer it at 20 cts. per pouud; ten pound. $\$ 1.85$.

We do not prepay field seeds, grass seeds, onion sets, seed potatoes, etc. Where seamless grain bags are used we make an extra charge of $16 \mathrm{c}$ each. But in most cases small orders can be packed in stout canvass bags, for which we make no charge.

Johuson Grass.--One of the most valuable Southern fodder plants. It may be cut three or four times in a season and does well on rough land. Yields a most abundant pasture or hay crop. 25 pounds to the bushel; sow twenty pounds to the acre. Prices on application.

Creeping Bent Grass per pound, 35 cts. Crested Dog Tail per pound, 35 cts.

Rhodle Island Bent Grass per pound, :3.5 cts.

Sheep Fescue per pound, $30 \mathrm{cts}$.

Hard Fescue per pound, 30 cts.

Tall Jeadow Oat Grass per pound, 25 cts, Wood Meadlow Oat Grass, per pound, (\$0.

Ammual Sweet Vernal pè pound, 20 cts.

Sweet Vernal, True Perennial, per pound so cts.

\section{Clover, Timothy, Millet, Cane, Etc.}

\section{WHAT CLOVER WHL DO.}

From The Practical Fruit Grower, Yor. 19. Igoo.

Bradford Miller, of Topeka, Ks., furnishes a raluable article on clorer growing to Sec. Coburn, of the Kansas Board of Agriculture. There is so much solid truth in his concluding paragraph that we present it and urge every farm reader to memorize his points:

"It is claimed very generally by clover growers that a field upon which a good crop of clorer is grown for two successive years will, when replowed and planted to corn, yield from fifteen to twenty-five bushels more corn per acre than it did before sown to clorer, or than similar land by its side will which has not been thus treated. The percentage of increase is quite as large in raising wheat, oats, potatoes, and other crops. To explain just how this is done is not the purpose of this paper, but to speak of the fact which has been fully established both in this state ard elsewhere. The plant draws nitrogen from the air, and stores it in the soil for the use of succeeding crops. The roots of the clorer penetrate to a great depth in the unplowed subsoil, drawing nutriment therefrom, assisting in holding moisture, which, when the roots die and decas, increase the fertility of the soil as well as the storing capacity for moisture, and with its sister, alfalfa. has justly earned the name of the "silent subsoiler," whose success and efficiency are generally admitted and admired."

Alfalfa.-The great clover of the Southwest? It succeeds best in dry ituation. To secure best results should be sown on high dry.ground; it bears cutting two or three times during the season. and yields about six tons forage per acre. Field should be kept tolerab1y clean from weeds. the first season, after that alfalfa will take care of itself and crowd out everything foreign. Roots extend to great depth and consequently capable of resisting great drouth. 60 pounds to the bushel; sow fifteen pounds to the acre. Price on application.

Merchants not receiving our Wholesale Price C'ard of Field Seeds, irass Seeds, Sweet Potatoes, Onion Sets, etc., are reruested to write pr same. We give you prompt service and save rou freight.

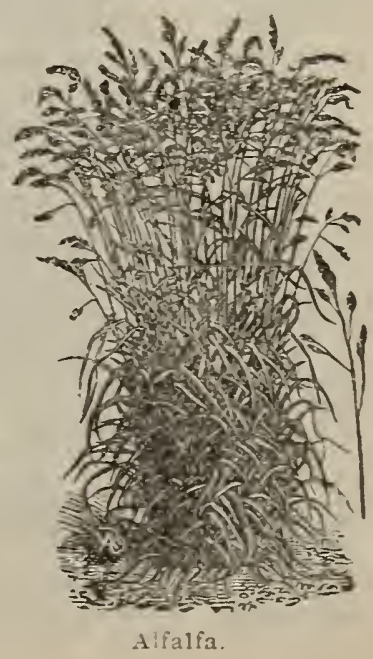


Clover, Mammoth or Sampling.-A perennial. In habit similar but a great improvement upon Medium Red. It lasts much longer, grows much larger in every way, and on good soil usually obtains a height or length of five to six feet, and is therefore a much more abundant yielder. It can be depended on to yield a fourth to a third more than the ordinary clover. Great care should be taken to get the genuine Mammoth as the seed in appearance somewhat resembles the Medium Red, and by some unscrupulous dealers this fact is taken advantage of and Medium substituted, as true Mammoth is always higher in price. We have true genuine Mammoth which you can depend upon. 60 pounds to the bushe1; sow ten pounds to the acre. Price on application.

Red or Medium Clover.-A perennial. This is the variety most generally used. We have both Eastern and native grown seed which we offer in three grades. 60 pounds to the bushel; sow eight to ten pounds to the acre. Prices on application.

Alsyke Clover.-A perennial. Succeeds best in stiff soil and in marshy lands which are too wet for other species. Will withstand most severe cold. It is also highly recommended for bees. 60 pound to the bushel; six to eight pounds to the acre. Price on application.

Japan Clover.-A perennial, growing about twelve inches high. It is the most valuable in hot and dry climate as it thrives in the dry season and in any soil. It is also valuable for turning under as green manure. Sow in the spring broad-cast at the rate of from fifteen to twenty pounds to the acre. Price on application.

Crimson or Scarlet Clover.-An annual, one to two feet high, with bright scarlet flowers. One of the best known clover crops for winter, preventing damage by washing and greatly enriching the soil. The most expensive elements of manures; the nitrogen or ammonia, is collected by the clover from the air, and left in the soil. It is a winter clover, making its best growth during cold or cool weather. Sow broad-cast in August or September among such crops as corn, tomato, buckwheat, etc. at the rate of ten to fifteen pounds to the acre. Plow under for green manure or cut for stock or pasture or convert into hay Also useful in orchard and vineyards for green manuring. Price on application.

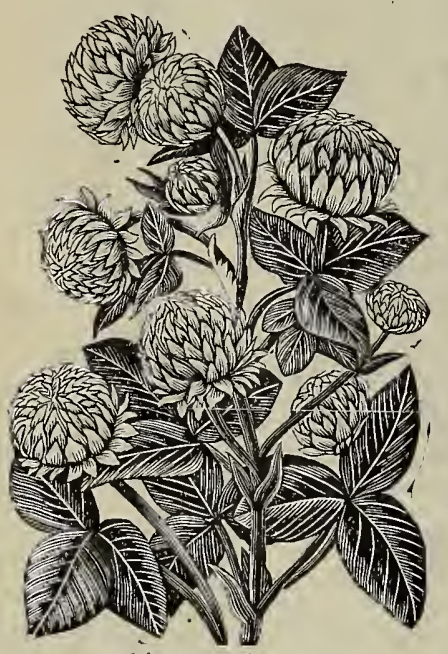

White Dutch Clover.

White Dutch Clover.-A perennial. And very valuable in this section. It makes an excellent turf that stands constant tramping; it is of dwarf habit, stems creeping and rooting at the joints; it spreads very rapidly and is very hardy resisting extremes of heat and cold, dryness and humidity, and accommodates itself to all kinds of soils. It is valuable in mixtures for permanent pastures, its forage being very sweet and nutritious and much relished by cattle. The seed should be sown in the spring. In mixtures, one pound; alone, six pounds to the acre. Prices on application.

Timothy Seed.-The leading grass for hay. It is most suited to moist loamy or clayey soil where it produces abundantly. Its hay is very nourishing and can be preserved for a long time. It is often sown along with red clover and the nutritive value of the hay is greatly increased by this mixture. Weight 45 pounds to the bushel, eleven or twelve pounds to the acre. Several grades are always on the market, differing in purity and vitality. In this, as well as all other seeds, it is always economy to buy the highest grade. Prices on application.

Mixed Bird Seed in bulk, per pound Ioc, not prepaid. Special prices on large quantities.

\section{BROOM CORN.}

As we all know, there has been a Broom Corn Trust for several years, but this differs from other trusts from the fact that the producer or the farmer holds the whip hand. Enormous prices have been paid by the trust, and the brush is always snapped up as quick as the crop is ready for market. An idea of the prices paid can be obtained by reference to the market as printed in the newspapers. We print herewith a clipping from the Chicago Market report :

Clipping from Chicago Market report under date of June 7th:

BROOM CORN-Is ruling about the same as it has of late. Dealers say they have been having a good steady trade. It is very evident that the Corn outside of what is held by the trust will all be wanted. The tone of the market is very steady, although holders a ppear to be willing to sell. Prices are holding up to late quotations. There is hardly a ny Corn and very little remains in the country. Self working, fair to good, per ton_.\$180 oo@ Self working, choice, per ton ......

Dwark length and color, per ton.................... I90 00@20000 Hurl, common, rough, coarse.. I65 co@ 17500 Hurl, good color, reasonably

smooth and good....................... I75 00@ I80 oo . choice, fine, green................ I9o ool

Small lots, selected to fill orders, bring over these prices.
Broom Corn, Improved Missouri Evergreen-The best past variety in cultivation on account of color and quantity of brush; four it ripens early, grows eight to ten feet high. Brush good length, fine and straight. We also carry several other varieties, but the IMPROVED MISSOURI EVERGREEN has shown itself to be soitsto superior we hardly care to recommend any other. Our stock of this seed is very fine, strictly true to name and of good growing vitality. Enormous profits have been made by farmers the past season growing Broom Corn. You should try at least an acre. 46 pounds to the bushel; sow eight to ten pounds to the acre. Price on application.

Merchants not receiving our Wholesale Price Card of Field Seeds, Grass Seeds, Onion Sets, Sweet Potatoes, etc., are requested to write for same. We give yov prompt service and save you freight. 


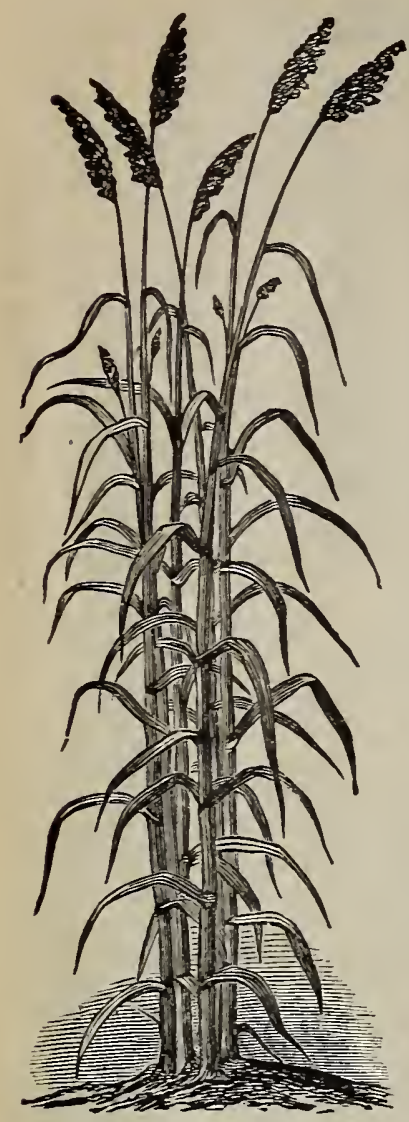

Amber Cane.

Cane Seed, Early Amber-We wish to call the attention of farmers, and especially dairymen, to the use of Cane as a fodder plant. It cannot be fully appreciated unless tried. It may be made to furnish the principal prorender for cattle, horses and mules from August until the following spring, and as a summer pasture for sheep, a wide field may be open for it. As a soily food for swine it is excellent. It can profitably be grown everywhere. It will grow right along through the most serere and prolonged drouth. As a fodder crop it cannot be excelled. The stalks of cane contain a considerable amount of sugar, therefore will be eaten up clean. This variety is earlier than Orange, enormously productire, and best for pasture or as a hay crop, as sereral cuttings can be made from it, and has been known to yield in a single season forty to fifty tons per acre. For fodder or pasture, sow broadcast, or through drills, at the rate of one to one and one-half bushels to the acre; 50 pounds to the bushel. Price on application.

Cane Seed, Orange-Best for sorghum. This excellent variety in good soil will yield 140 to 175 gallons of sorghum to the acre. Somewhat later than Amber. Prices on application.

Kaftir Corn, White-The plant is low, stocky, and perfectly erect. Stock eat it greedily. It will withstand the most extreme drouth and is rery raluable for both a hay and grain crop. The tops containing the grain may be cut off and fed as corn. It also makes excellent meal and rivals buckwheat for cakes. 50 pounds to the bushel. For fodder broadcast one bushel to the acre, or two quarts to the acre when planted as Indian corn. Prices on application. fodder.

Kaflir Corn, Red-A good variety for

Jerusalem Corn-The best and surest grain for dry countries and seasons. It grows about three feet high, makes one large head on main stalk and sereral smaller heads on side shoots; sometimes as many as eight heads. Grain pure white and nearly flat in shape. Good food for man or beast. Cultivate as corn; sow four to five pounds to the acre. Price on application.

Milo Maize-The grain makes a rery fine feed for fowls and stock very valuable for forage. Withstands drouth andmakes a crop where other Corn fails. Plant as Corn, four or fire pounds to the acre. Price on application.

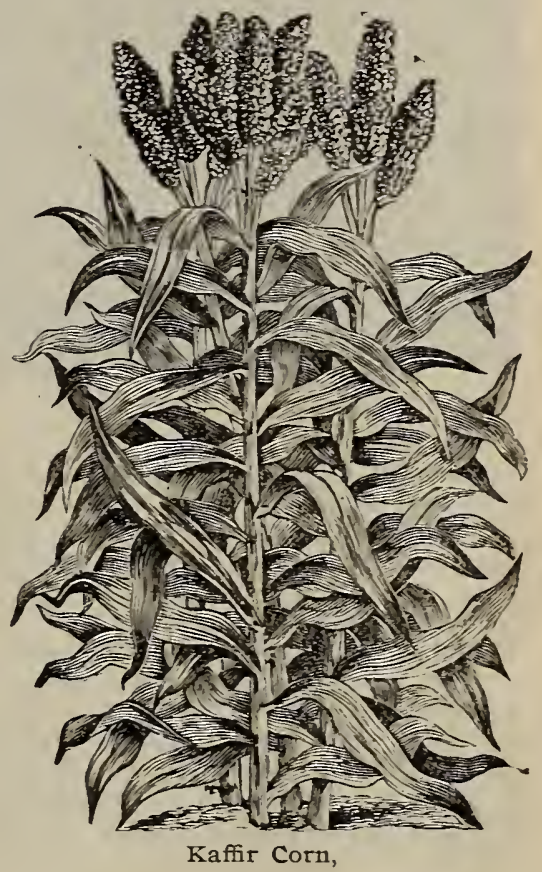

Millet, Common-Not so tall as German, but many prefer the hay for horses. Seed almost white in color. 50 pounds to the bushel. Sow one-half bushel to the acre. Prices on application.

Millet, German-The best all purpose Millet grown. Great care should be used to get PURE GERMAN. The seed is inclined to run out, and mixes badly with other varieties, This kind of seed will not produce the quantity; the hay is also rery inferior. A great amount of Fox-Tail is also usually found in Millet seed. With our new mills we remore this, as well as other foreign seed, and offer pure, straight German. Sow our superior, re-cleaned, true German Millet, and reap a bountiful harrest. 50 pounds to the bushel; sow one-half bushel to the acre. Prices on application.

Millet Hungarian or Hungarian Grass-Very popular in dry sections. Stalks covered with a profusion of blades, which makes it rery valuable as a hay crop. It is also valuable for thin soil, where it thrives. It can be sown later than other varieties of Millet, as drouth does not affect it. 48 pounds to the bushel. Price on application.

Millet, Hog or Manitoba-Has proven itself to be one of the most valuable Millets grown for hogpasture. Seed about double the size of German and ripens about two weeks earlier. Grows about four feet high; its yield is surprising. Sow twenty-fire pounds to the acre. Price on application.

Millet, Siberian-A new variety, exceedingly prolific; resists drouth; chinch bugs do not care for it: it stools abundantly. Our seed is pure. Sow one-half bushel to the acre. Price on application.

\section{OUR PRICES ARE REASONABLE,}

\section{OUR STOCK IS COMPLETE.}

OUR SEEDS ARE TESTED.

Try our Mixed Lawn Grass. Per lb. in 1 lb. cartons, $25 \mathrm{c}$; per bushel in bulk. $\$ 351$. 
Oats, White Lincoln-It has been the custom of some feed stores and dealers to send out, as Lincoln Oats, common White Oats, such as are sold for feed. This class of stock is bought from elevators with no idea of using it for seed, and usually comes from eight or ten farmers or more. This stock is bulked by the elevator, and when loaded in the car becomes mixed, so that it contains all kinds of oats, early and 1ate, good and bad, and is, of course, unfit for seed. Our seed stock is cultivated especially for seed, and is all grown by one man. We offer the

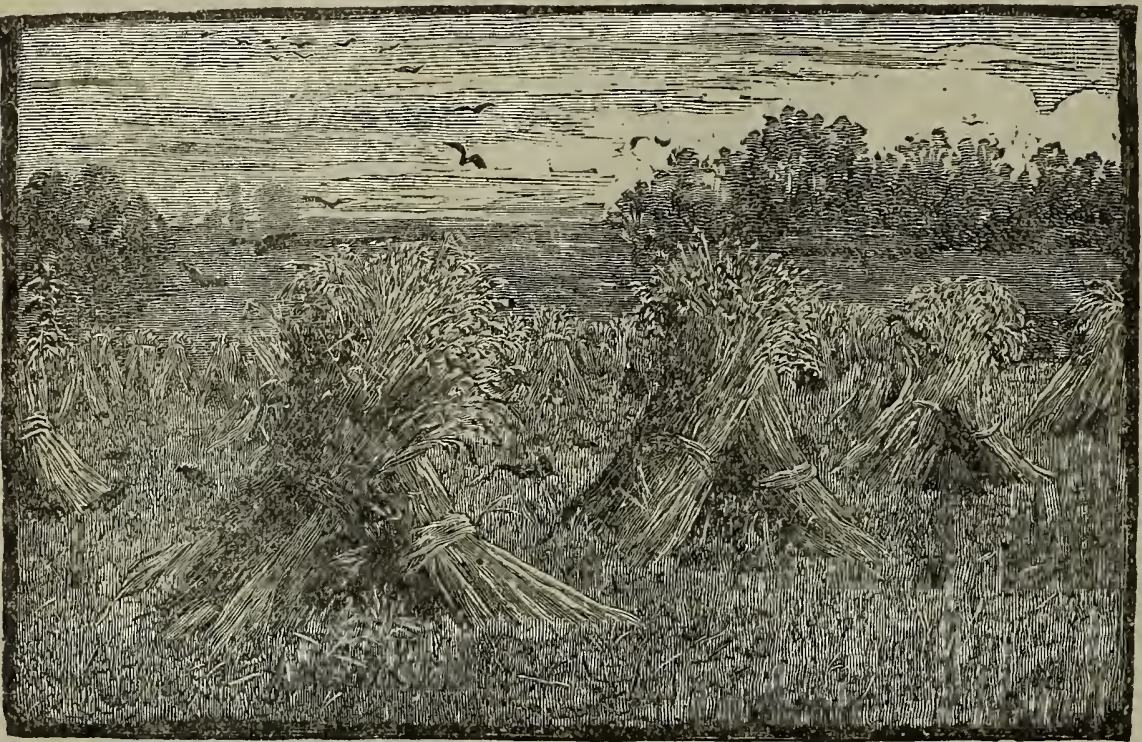
pure Northern grown seed stock. We believe the true Lincoln is the best Oat ever produced. The claims we make for this Oat are earliness, enormous yielding quality, freedom from rust, and that it stands crouth better than any variety grown, and have weighed as high as fortyseven and a half pounds to the measured bushel. These claims have been ful$1 y$ sustained on every point and from many sections. On account of its stifi straw it will stancl up perfectly under weather that causes other varieties to lodge. It is the best and most economical variety for feeching on account of its thin hull, heary meat and soft nib. Old, worn-out stock should be changed. Try at least

enough to grow new seed.

Field of White I,incoln Oats. If you sow our pure sced of this valuable Oat, you can double your yieid. We are able to point you to
hundreds of calses where this has been done. When the Oats have been harvested they will alwas bring a few cents more per bushel, for above reasons, than other varleties. 32 pounds to the bushel. We will quote you a very reasonable price on application.

Oats, White Rusisian.-Not such a heavy yielder, does not stand the drouth so well, and later than Lincoln, therefore not so well suited to this section. 32 pounds to the bushel. Price on application.

Gats, Wallare.-A yellow oat that has sprung into great favor in this section. Early, a good yielder anct very popular with the farmer. 32 pounds to the bushel. Price on application.

Oats, lexas Rerl.-Rust proof, and a good all round early variety. This oat is very iargely grown in this section. but lhe main objection seems to be that it will not withstand drouth, and that a good crop in this obtained only under the most farorable circumstances. 32 pounds to the bushel. Price on applican be cation.

If you want something cheap in Oats, we have some carefully selected and recleaned ed Home Grown Oats which are much better than the average and which we will sell at market price of ordinary Oats.

Seed IRye.-Northern recleaned, 56 pounds to the bushel. Sow one to one and one-half bushel to the acre. Price on application.

Popcorn.-Always a profitable crop and ready market. We will give you a contract to grow an acre or two for us. For description of popcorn see page 15.

Dwarl Esisex liape.--The greatest hog, cattle and sheep forage in the world, much like the rutabaga in appearance; roots something like cabbage; Howers bright yellow. Seeds are produced in pouls about two inches long. Under ordinary conditions, the plant reaches a height of one and one half to four feet. For its best development, it requires a rich loamy soil, but with a favorable season can be grown in light soil with success, It is usually ready for use in eight to ten weeks from time of sowing. Sheep and hogs may be turned in as soon as field is ready for use. Cattle should be turned in on the crop somewhat later when crop becomes better developed. Care should be taken that all animals have free access to salt at all' times. Rape endures much severe cold weather, and will be found good pasture after all pasture grasses have succumbed to frost. It possesses a high feeding value, producing a remarkable flow of milk, and having excellent fattening qualities. When fed to milk cows should be fed directly after milking, thus, aroiding any langer of tainting the milk. To stockmen and dairymen interested in the culture of rape, we will matil special facts upon application regarding its culture and use. Price per pound $15 \mathrm{cts}$, postpaid. Freight or express per hundred, $\$ 8.50$. Sow three to five pounds to the acre.

Teosinte-A forage plant that is the greatest producer of the are. The stalks in alpearance resemble Indian Corn, but the leaves are much longer, broatler and sweeter. It grows twelve to fourteen feet high, producing a great number of shoots which are covered with heary foliage; as much as eighty-five stalks have been wown from a single seed. This wonderful plant will produce as high as fifty tons to the acre. (One of our farmers cut two wagon loads of forage from a single ounce of seed, A growing fleld in itppearance resembles a mammoth crop of corn. It may be cut three or four times luring the season. Extreme drouth or wet weather does not affect it. So dense and high does it grow that it is almost impossible for a man to push his way through a well grown ficld, Plint as coln: three pounds to the acre. Plit.. $10 \mathrm{c} ;(\% .1 .5 \mathrm{c} ;+1 \mathrm{~h}, 4.5 \mathrm{c} ; 1 \mathrm{~h} . .+1.50$, postpaid. 


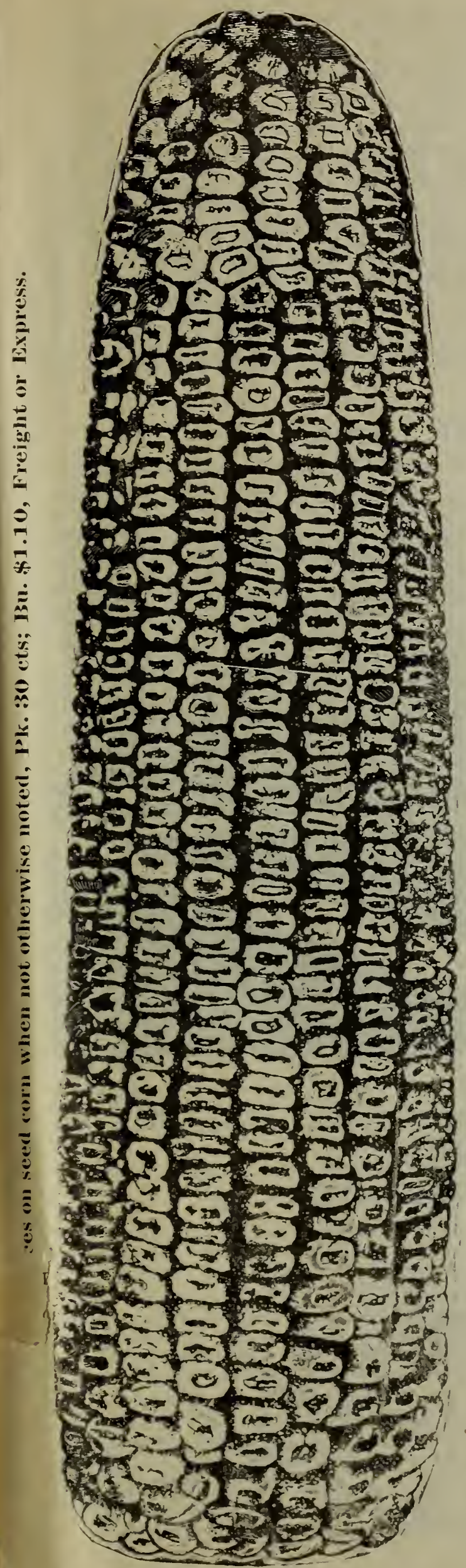

A Cut of Our Sul erior Strain of Iowa Gold Mine Corn.
Brazilian Flour Corn-For the past four years have urged the cultivation of Flour Corn. It makes bread, cakes, etc., equal to wheat flour, and by many preferred. Will far out-yield common field Corn as to number of ears. Will produce four times as much fodder, being a great variety to stool. Price, Pli. 65 cts; Bu. \$2.00. Freight o Express.

Iowa Gold Mine-A greatly improved strain of Pride of the North, being much larger and but little later. Ears of good size and symmetrical in shape. Has been a favorite among stock feeders since its introduction, from the fact that the cob is sma1l, the grain is soft, not possessing the flinty qualities of Pride of the North.

Leaming-The king of earlies. With an established reputation as a wonderful cropper. Aside from Pride of the North, has proven to be the only extra early Field Corn that does all that is claimed for it. Leaming has been known to yield one hundred and twenty-five bushels to the acre. Ears deep yellow with small red cob.

Corn, Improved Golden Beauty-The largest grained Dent Corn in cultivation. Perfect ears with ten to fourteen straight rows of golden yellow grains; cobs small. This stock is a very high strain of pure northern grown seed, and one of the heaviest croppers we ever handled.

Corn, Legal Tender-This variety is also called Premium Taker and justly, for we doubt if any other variety grown has taken the number of premiums at state and county fairs as this variety. The corn is very productive, of uniform, pure yellow color, enormous large and long ears, with a deep grain on a rery small cob. Has from sixteen to twenty rows. The kernels are deep and the ear holds its size toward the point until nearly tapered off. It matures in about one hundred and ten days. Price $\mathrm{Pk}$ 35 cts; Bu. \$1.25. Freight or Express.

White Cap hellow Dent-This popular new variety possesses the earliness of the Leaming combined with ears of very large size. Our grower assures us that this corn matures in ninety days after planting, and will grow a larger crop on poor soil than any other variety. The grains are of a light yellow with a white cap. The ears are eight to ten inches long and well filled to the tip. Sixteen to eighteen rows, and will measure about two inches in diameter; has a small cob, and is perfectly white in appearance until shelled. Try this corn for poor soil.

Corn, Hickory King-A grand old variety which seems to have been somewhat overlooked. The smallest cob in comparison with the size of the grain of any white corn in cultivation. Always commands a price above the market for milling purposes. For hominy, it excels then a11. Heretofore we have been unable to supply our trade, and many of our customers have been disappointed in securing seed. This season we can assure you of a good supply of straight Hickory King.

Coru, Iowa Silver Mine-Stalks grow to a height of seven to eight feet. It has not a large growth of fodder, having been breal essentially for yrain, though it has plenty of blades to suppont the growth and is as well rooted as any corn grown. Ears measuring from ten to twelve inches in length and weighing one and one-half to two pounds are not uncommon. The ears are very uniform in size and shape, with sixteen to twenty rows of deep, pure white kernels set on white cob. It is ready for the market earlier than any white corn grown. Seventy pounds of this corn in the ear will make sixty-two pounds shelled.

Our Seed Corn this season is grown by a northern grower of wide reputation for care and integrity, and we feel justified in saying that we can assure you of the very best service as to vitality and care in selection.

Dealers wishing Seed Corn in quantities will please write for our Price Card of Field Seeds, Cirass Seeds, Onion Sets, etc. 
Corn, Champion White Pearl-Not so early as Iowa Silver Mine, but preferred by many from the fact that it will produce a better crop in drouthy sections, as the lot July and August sun does not seem to affect it like most varieties. Chamnion White Pearl and Iowa Silver Mine are rapidly becoming the most popular white corns in cultivation. In using these varieties you are not planting some untried novelty, but corns that have been thoroughly tested and are not found wanting.

Cow Peas-The Cow Pea has proven itself to be one of the greatest fertilizers to use, and, in fact, many declare that it fully equals the fertilizer drawn from the barn yard. An extra crop of forage can be grown each season by broadcasting the peas through the corn at the last plowing. The peas can then be pastured after the corn is snapped off, or after the corn is shocked and the fodder removed. You not only gain this extra forage, but your ground is greatly benefited. Green crops plowed under is one of the cheapest ways of improving the soil; for this purpose the Cow Pea has no superior. They make poor land rich and good land more productive. In its capacity as a nitrogen gatherer its growth-largely enables the farmer to dispense with the use of nitrogen or ammoniated fertilizers. Nitrogen or ammonia in commercial fertilizers is valued at fifteen cents per pound. The Cow Pea, to a greater extent than any other leguminous crop, has the power to extract this costly nitrogen or ammonia from the atmosphere. The Cow Peas are also largely used for fertilizing strawberries. Broad-cast at the rate of one bushel to the acre. 'The best varieties are Whippoorwills, Clays and Blacks. We also offer Mixed Cow Peas which are a combination of the above varieties and find great favor for pasture. Sixty pounds to the bushel. Price on application.

\section{S. S. Co.'s IVIXED LAWN GRASS.}

Prepared and offered to our trade wiłh a view to overcoming the many serious difficulties that have heretofore existed in securing a good lawn. This mixture is prepared with great care in all cases, and with the aim to have you succeed in securing a lawn, rather than with a view to securing large profits for ourselves, and will certainly, if properly sown, give you quick and pleasing results. Will flourish in shaded places and on terraces as well as in more favored locations, it being especially prepared to meet such necessities.

Heavy and very careful seeding by ${ }^{\circ} a$ competent and experienced person is very necessary, and we would especially urge our customers to consider this fact in seeding,

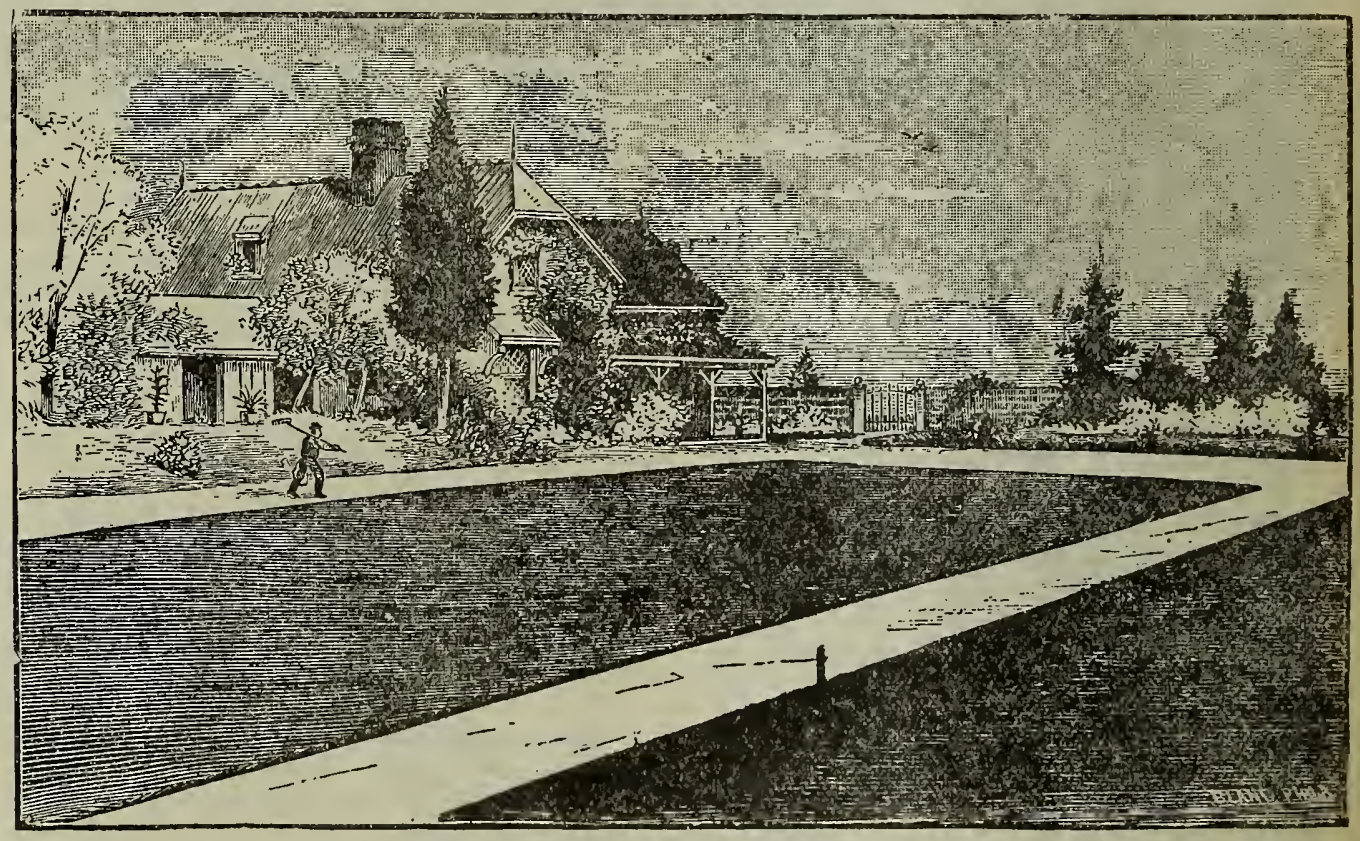
as it never costs as much to seed well at first seeding as to follow the so-called economical idea, namely: that of one-half seeding at first season, with the usual result of failure, then comes the necessity of reseeding a number of times before getting a lawn, meaning loss of time and additional expense. Per pound, postpaid, 30 cents; by express or freight, per bushe1, $\$ 3.50$.

\section{ASLING'S INSECT EXTERIMINATOR.}

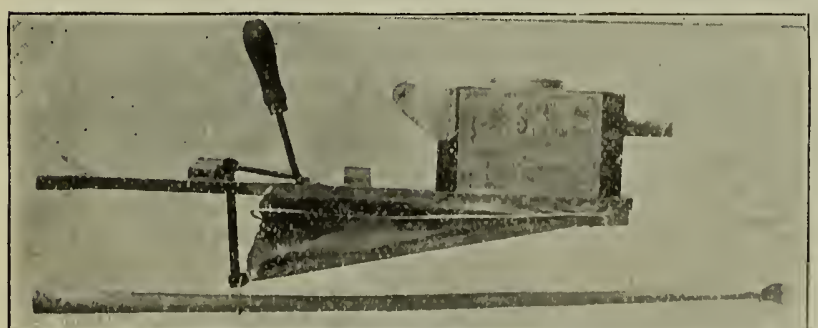

Fruit and vegetable growers will always find it necessary to use some means of destroying the myriads of insects that infest their crops.

This Sprayer will expel or destroy Potato Bugs, Moths, Canker Worms, Cabbage, Cotton and Tobacco Worms, Raspberry. Strawberry and Pear Slugs, Apple, Peach and Plum Aphis, and kill ali vermin on cattle, hogs and poultry.

A cuarter turn deflector supplied with each machine, which will be found useful in dusting the mincler side of the foliage on plants, making the hiding and hatching places of insects untenable.

One man can dust as many trees in a day as two men with a team and tank as used in the old method. This machine is a pronounced success and no fruit grower or trucker should be without one. Information regarding the preparation of any special mixture cheerfully furnished on application.

Price, carefully packed, $\$ 5.00$. 


\section{MOTH CATCHER.}

New-Great Invention. Patent August 28, 1900.

\section{IT PROTECTS THE ORCHARD.}

Kills the mother of the Apple and Pear Worm, the Coddling Moth; also the Stinging Fly, or Wasp-like insect that stings the fruit, the Tent Caterpillar, and the Borer Fly that girdles the trees and kills the orchard. Also catches the Peach and Plum Moth that make the Curculio, the June Bug, Colorado Beetles and other Noxious Insects.

\section{IT IS CHEAPER AND BETTER THAN SPRAYING.}

No Fruit Grower can afford to be without it.

Positively no poison used to kill man or beast.

\section{....PRICES....}

The small size is $10 \times 14$ inches, made to fit a twelve quart pan. Including torch, $85 \mathrm{cts}$.

Large size, $14 \times 20$ inches, fits an ordinary tub, sells at $\$ 1.00$.

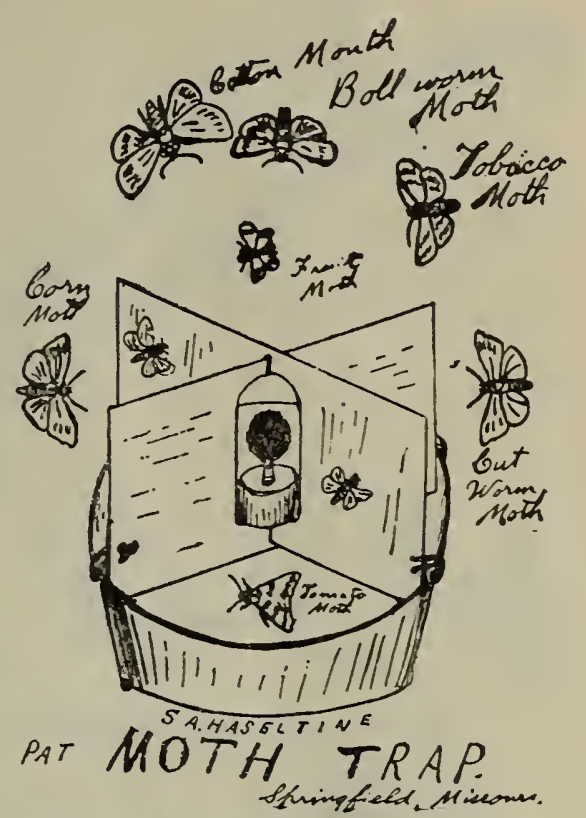

Springfield, Mo., Dec. 27, 1900.

I used Haseltine's Moth Catcher on my cabbage crop and in $m y$ peach orchard this season, and desire to say I find it an excellent thing for destroying the pests and will use more next year. S. S. TRACr.

Pearl, Mo., Nov. 26, 1900,

S. A. Haseltine: I am pleased with your Moth Catchers. I tried spraying, and this year I did not spray, but used yc $r$ Moth Catchers in eighty $(80)$ acres of orchard. They proved a great success. The per cent of perfect apples at gathering time was much larger than sprayed trees, and less fell off while small. It is better than spraying to make perfect fruit, and does not injure the fruit or trees or kill any stock or endanger human life, and is much cheaper than spraying. I would nerer spray again, but only use these Moth Catchers as I did this year. Yours truly,

J. B. TURNER.

Springfield, Mo., Oct. 29, 1900.

I used Haseltine's Moth Catcher in my sixty acre orchard this year. I bought six, and caught from a quart to a gallon of destructive Moths and Beetles in every trap each night. I went and bought ten more. I have experimented with spraying and the Moth Catchers. and I consider the Moth Catchers better than iny method of spraying to make perfect fruit, as it catches the insect that injures both trees and fruit.

A. HARRINGTON.

Spring field, Mo., Nov. 3, 1900.

I used Haseltine's Moth Catcher in a thirty acre orchard of mine this year. I am pleased with the result. The fruit was perfect and free from the work of Coddling and all other worms. The traps also caught the Borer $f l y$ and other insects that injure the trees and fruit. I have another orchard of ten acres that I sprayed. but did not use the Moth Catchers in it, and the fruit on the ten acres was badly injured by worms.

G. A. H. CLARKE.

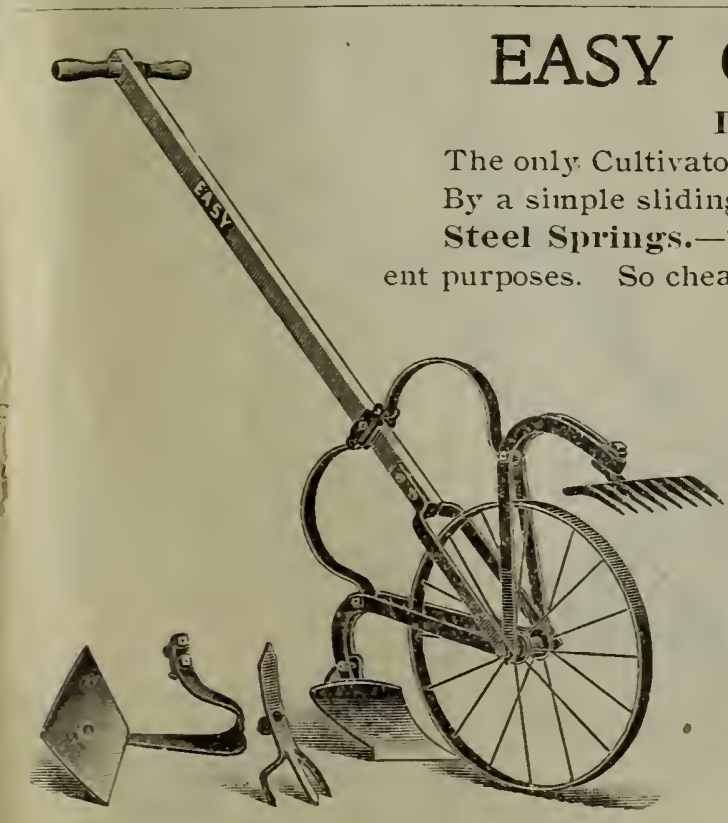

NO. 2.

\section{GARDEN CULTIVATOR.}

\section{IT DOES ITS OWN TALIKING.}

ng-slot, the handle is made to raise or lower for man or child. - Tools all made of the best of steel and can be used for differ-

No. 1 has a 15-inch wheel, to axle of which are attached the arch and handle, with a flat spring extending from arch to the handle. Made to suit those who want a moderate price plow.

\section{PRICE.}

No. 1-With Diamond and Bull Tongue.........\$2.75.

No. 1-With Turning Plow and Bull Tongue... S3.00.

No. 2 consists of a 16 -inch steel wheel with arches and handle attached to axle as shown in cut. A tempered steel spring extends from eitch arch to slot on handle, by means of which we make a perfect adjustable handle. Has a tool on each side of arch, and by turning over the handle can use one or the other.

\section{PRICE.}

No. 2-With Diamond and Bull Tongrue....... \$3.50.

No. 2 - With Turning Plow and any two other

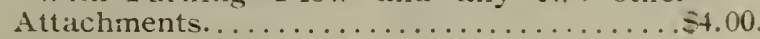

No. 2- With all Attachments as shown in cut.... 54.25. 


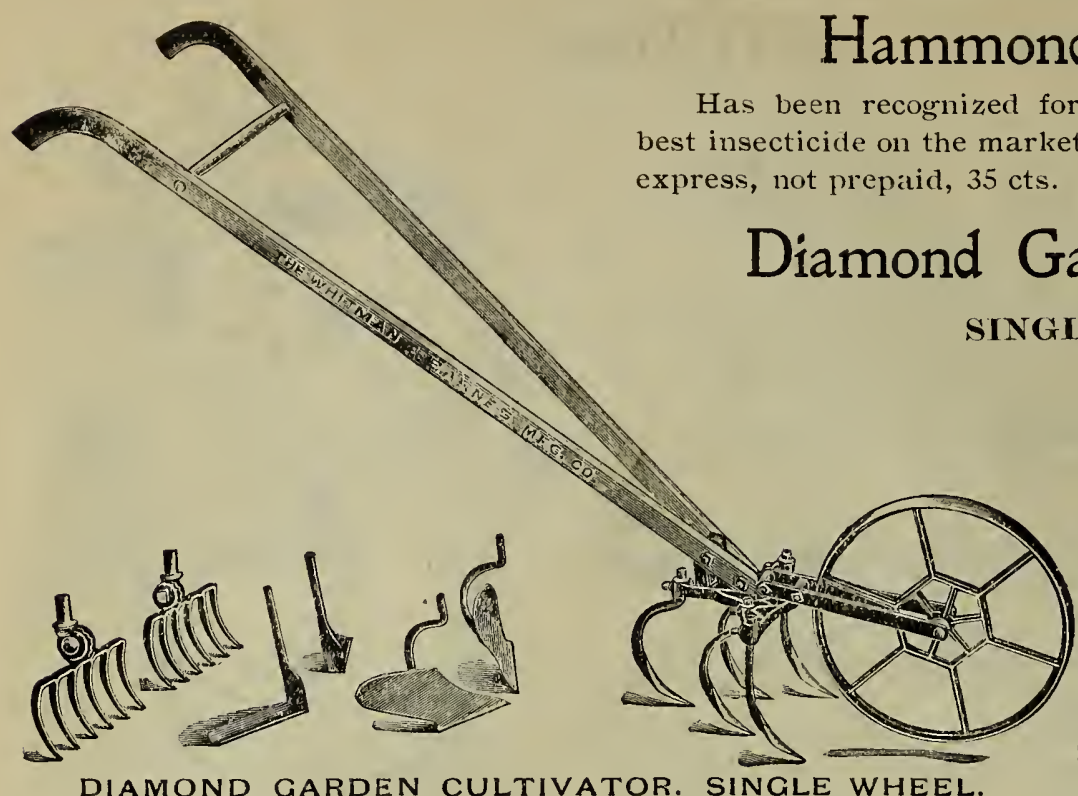

\section{Hammond's Slug Shot}

for the past twenty-five years as the best insecticide on the market. Per 1b., postpaid, $15 \mathrm{cts}$; $51 \mathrm{bs}$.,

\section{Diamond Garden Cultivator.} SINGLE WHEEL.

Designed especially for the home gardener. Light, desirable, strong and simple of construction.

As a labor saving investment will pay for itself in one week.

Price (carefully packed), including attachments as shown in cut, $\$ 4.00$.

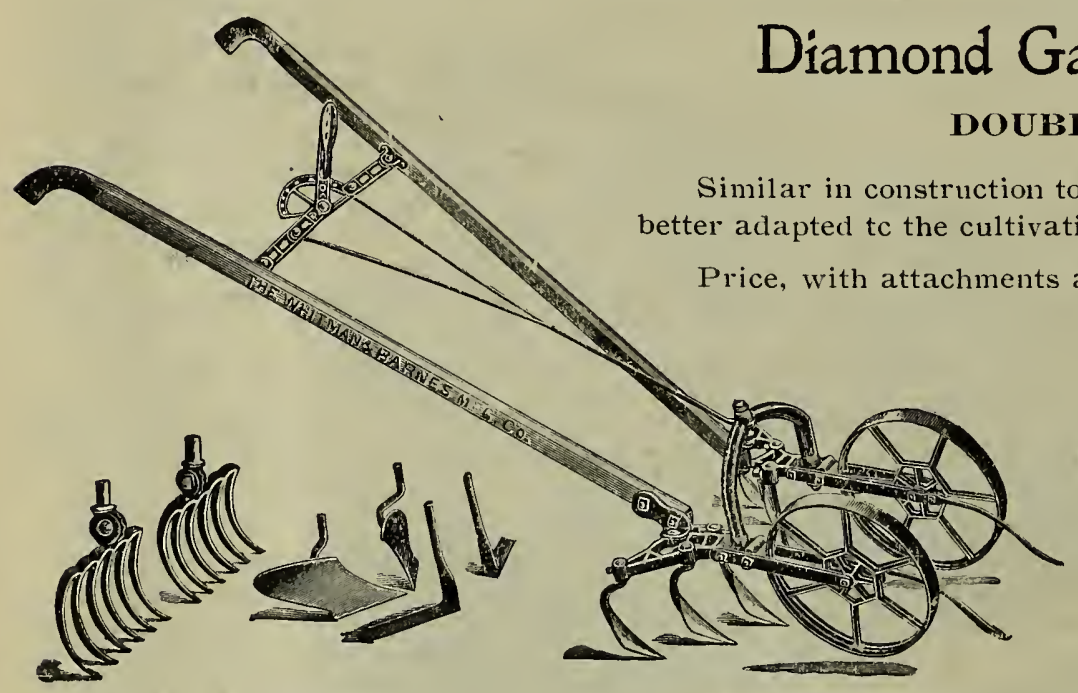

DIAMOND GARDEN CULTIVATOR. DOUBLE WHEEL.

\section{Cyclone Grass Seeders.} $\$ 1.50$.

Price, each, securely packed,

Chicago, or Fiddle Bow

Grass Seeders.

Price, each, $\$ 1.25$.

\section{Western Garden Drill.}

For simplicity of adjustment, regularity and reliability in seeding, is certainly equal to any drill offered. $\$ 6.50$.

\section{LAND PLASTER.}

This is a natural fertilizer, and will prove itself valuable when used as a top dressing in early spring, for lawns or meadows. It also adds to the yield and quality of the crop when used in the hill with corn. For lawns or meatlows broadcast at the rate of 100 pounds per acre. For corn, about a tablespoonful to the hill, planted with the corn. Price $\$ 1.25$ per 100 pounds.

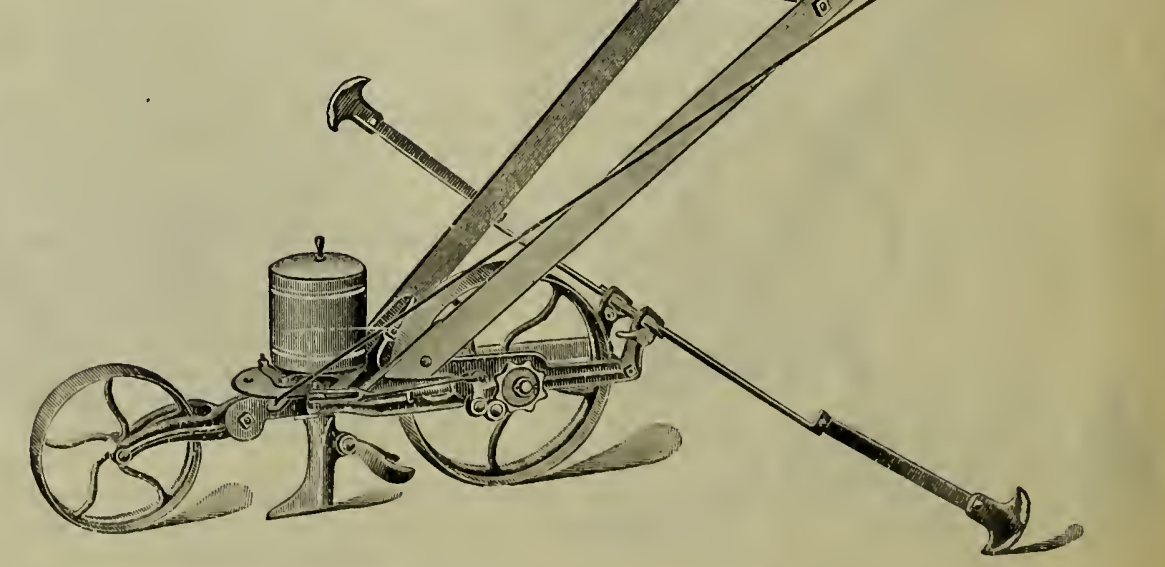

WESTERN GARDEN DRILL. 


\section{"PLANET IR." GARDEN TOOLS.}

Planet $\mathrm{Jr}$. Garden Tools are becoming so well known that it is superfluous to speak of their merits. To those of our friends who are unfamiliar with the many advantages they offer for the farm and garden.

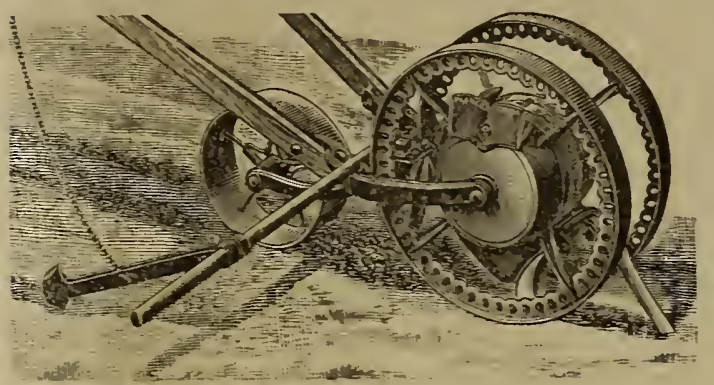

No. 2 Drill Seeder. Price, $\$ 7.00$.

Holds three quarts.

"Planet Ir." No. 1 Combined Drill, Wheel Hoe, Cultivator and Plow.-It has a complete set of cultivating tools. and all its work is apid. easy, perfect and delightful. When used as a drill the seed is sown with great regularity and at uniform depth. regulated at pleasure. The hopper holds one quart. From a drill it is changed into its other uses by unscrewing but two bolts, when any of the attachments show in the cut can be quickly attached. Price. 89.50 .

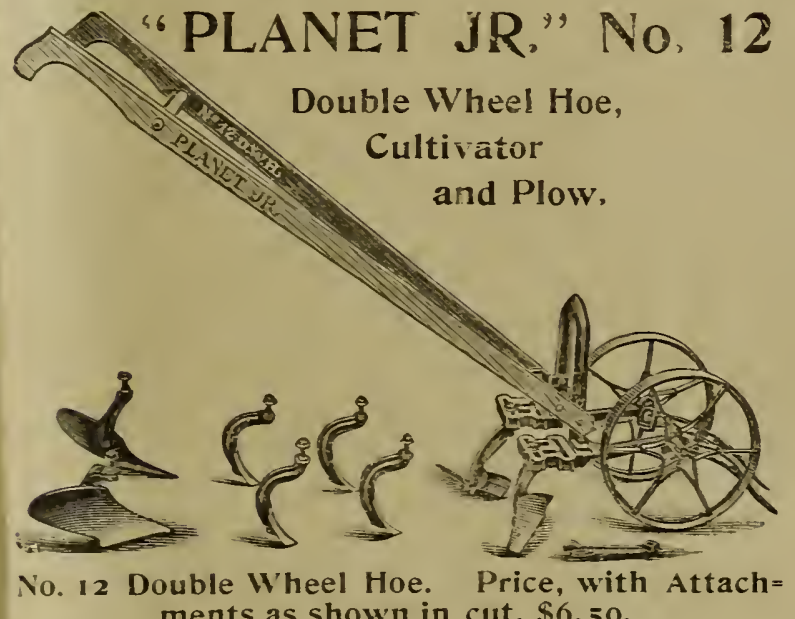

No. I Combined Drill Seeder, Wheel Hoe, Cultivator, Rake and Plow. Price, \$9.50. Holds one quart.

No. 10 Double Wheel Hoe Rake and Plow is a prime favorite among the older Planet $\mathrm{Jr}$. Patterns. It is particularly rigid aad strong. excellent work is certain with the hoes in close level cultivation. Deep tillage is the strong point of the four cultirating teetl. Furrow opening and plowing that of the twin plows. and the rakes are always useful in their line. Price complete. $\$ 6.00$.

Plain Double Wheel Hoe, plan being the same as No. 10, but having only the two hoes or scrapers: an invaluable tool in the culture of onions, beets, etc. Price. $\$ 4.50$.

No. 16 Single Wheel Hoe.-This tool has two hoes or scrapers, three cultivator teeth, one pair rakes, one large plow. No home garden should be without one of these tools. Price. complete, \$5.50.

\section{WHEEL HOES AND ATTACHMENTS.}

Wheel Hoes are the $c$ mpanion implements of Seed Drills, and are indispensable to market gardento surar beet rrowers. to nursermen, and to all farmers who grow roots for stock or vegretables for market. By using grood wheel hues. one can plant five times his usual acreage of small hoed crops, without fear of beingr caught in their cultivation.

It is a much less common mistake now than it was twenty years ago to imagine that these finely-macle tools are fit only for the playthings of fancy farmers, or for the grardens of the rich: or, as one person expressed it. that they are tom handsome for any place but the parlor. Nothing conld be farther from the truth. The rich can gret along without them, anll the fancy farmer can pay for hand labor to take their place. Insteald of the parlor. the garden. the field and the farm are their natural homes.

In a word, while they are adapted to the strength of a boy or woman, they are built expressly for the

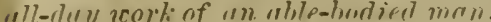

Wheel Hoes should be used "t the speed of a moderate ualk, making a stroke at each step. Much closer work can be done in this way, and the guiding of the tool is far easier. Fur rery delicate work. short strokes may be taken, three or four to a step. Any one can become skillful in a short time; the chief rule is to set the hoes right. and then watch the wheels only, keeping them at the proper distance from the row.

\section{“PLANET JR.” GRASS EDGER. PRICE, \$6 00.}

Extreme Neaturs is the great secret of attractiveness in grounds surrounding a house. The (irass Edgrer assists wonderfully in producing this effect. It will edge either straight or curved work. paths, drives, open burders or fliwer beds. at the speed of a mile an hour. It should be the constant companion of the lawn mower.

Strawbery Growers will find the Grass Edger, with the hoe removed, a rapid and perfect twol for cutting off surplus i unners. 
